\title{
COMPUTER SUPPORT EFFECTIVENESS AN EXPLORATORY STUDY
}

\author{
By: \\ Marlene Elliott

\begin{abstract}
A Thesis submitted to
the Faculty of Graduate Studies and Research

In partial fulfillment of the requirements for the degree of

Masters of Business Administration
\end{abstract}

Eric Sprott School of Business

Carleton University

Ottawa, Ontario

May 2002 
National Library of Canada

Acquisitions and Bibliographic Services

395 Wellington Street Ottawa ON K1A ON4 Canada
Bibliothèque nationale du Canada

\section{Acquisitions et} services bibliographiques

395, rue Wellington Ottawa ON K1A ON4 Canada
The author has granted a nonexclusive licence allowing the National Library of Canada to reproduce, loan, distribute or sell copies of this thesis in microform, paper or electronic formats.

The author retains ownership of the copyright in this thesis. Neither the thesis nor substantial extracts from it may be printed or otherwise reproduced without the author's permission.
L'auteur a accordé une licence non exclusive permettant à la Bibliothèque nationale du Canada de reproduire, prêter, distribuer ou vendre des copies de cette thèse sous la forme de microfiche/film, de reproduction sur papier ou sur format électronique.

L'auteur conserve la propriété du droit d'auteur qui protège cette thèse. $\mathrm{Ni}$ la thèse ni des extraits substantiels de celle-ci ne doivent être imprimés ou autrement reproduits sans son autorisation.

\section{Canadä}


The undersigned recommend to the Faculty of Graduate Studies acceptance of the thesis

\section{Computer Support Effectiveness: An Exploratory Study}

Submitted by Marlene Elliott in partial fulfillment of the requirements for the degree of Master of Business Administration
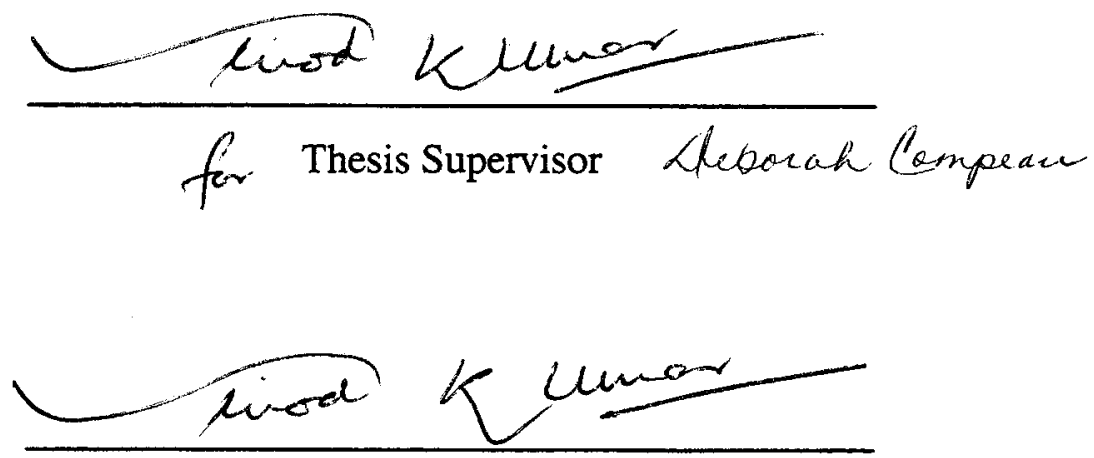

Director, Eric Sprott School of Business

Carleton University

May 2002 


\begin{abstract}
How can organizations provide effective computer support? A model of computer support effectiveness is created to use for future research and as a roadmap for IS managers to highlight areas for improving support. The model is divided into five main independent variable groupings: Organizational Structure, Management Attitudes / Practices, Computer Support Personnel, End User Experience / Needs, and Resources. Some of the key management-related variables influencing support effectiveness included the use of user-related success criteria and reasonable distribution of resources between support and application groups. Job satisfaction, morale, stress, end user skill level, and other variables also had an impact.

The key recommendations for managers flowing from this research are hiring support personnel with strong people skills and training them on the users' requirements and impacts to promote effective prioritization and communication. Time should be invested in implementing formal problem prioritization processes to ensure management, support personnel, and users have a common understanding and expectations.
\end{abstract}




\section{ACKNOWLEDGEMENTS}

I would like to give special thanks to my thesis supervisor, Dr. Debbie Compeau, for her enthusiasm, encouragement, and assistance throughout the entire thesis process. I would also like to thank my husband, Paul Madden, for his love and support and my parents, David and Gay Elliott, for teaching me that anything is possible. 


\section{TABLE OF CONTENTS}

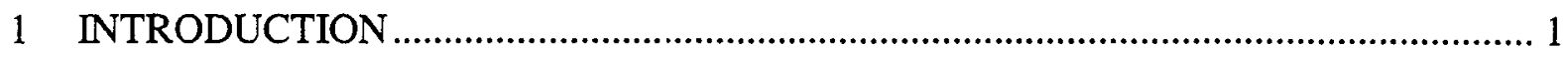

1.1 Management Problem and Importance ............................................................ 1

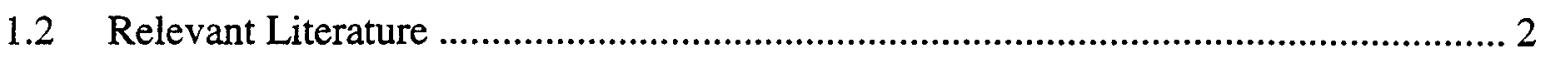

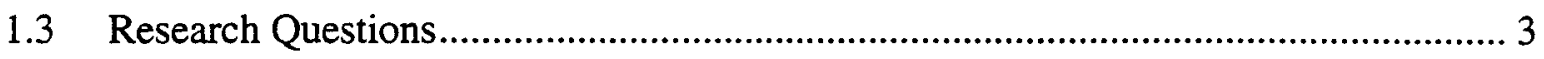

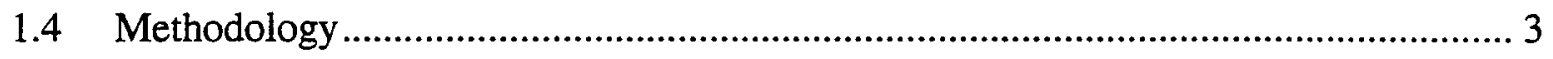

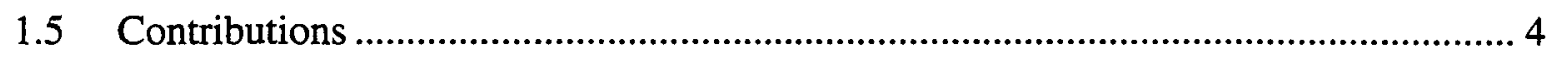

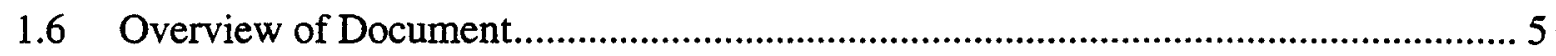

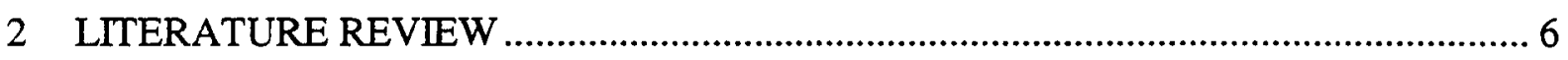

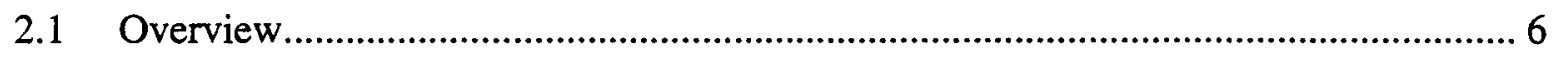

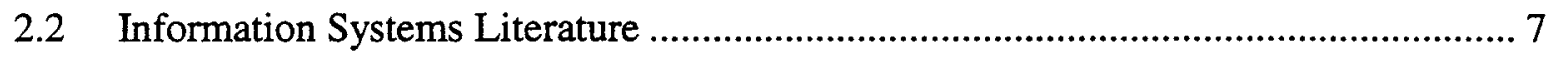

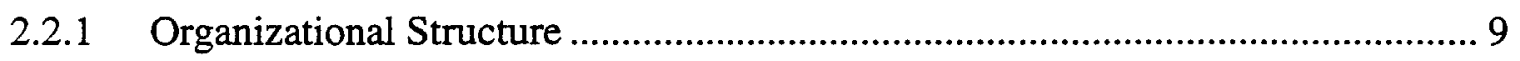

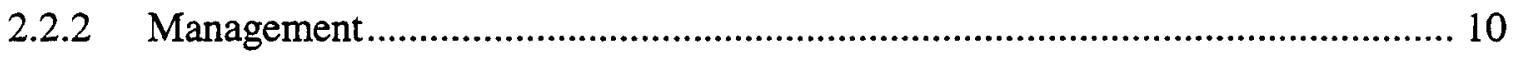

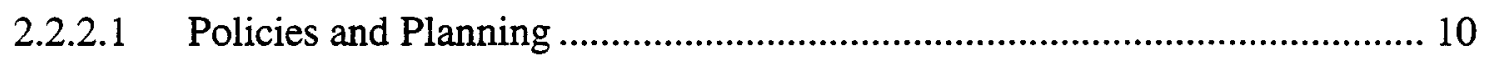

2.2.2.2 Management Practices..................................................................... 11

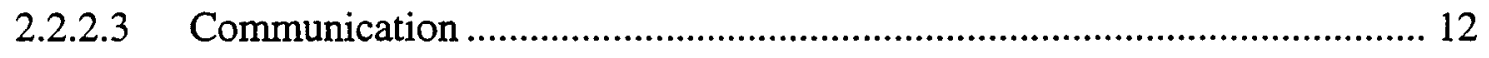

2.2.3 Computer Support Personnel .................................................................. 12

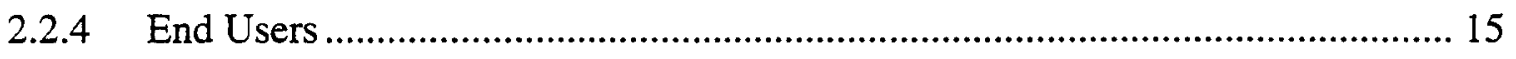

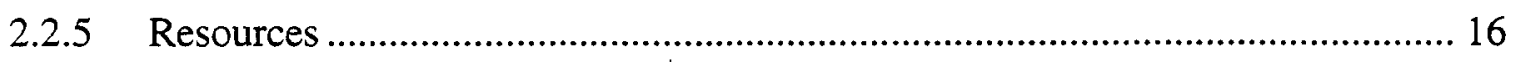

2.2.6 Information Systems Effectiveness ........................................................ 17

2.2.7 Information Systems Literature Conclusion .......................................... 18 


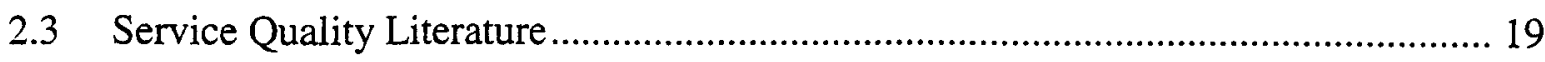

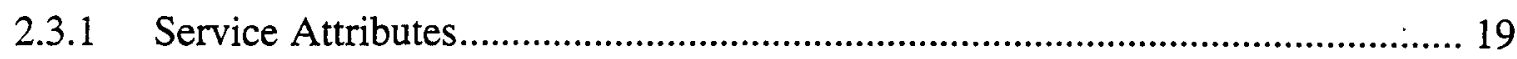

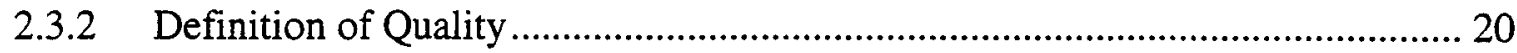

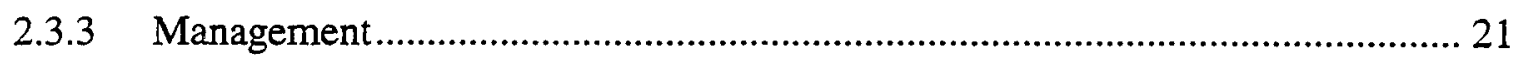

2.3.4 Computer Support Personnel Attitudes / Practices ........................................ 24

2.3.5 Service Quality Measurement ................................................................... 24

2.3.6 Service Quality - Consumer Satisfaction Relationship................................... 29

2.3.7 Service Quality Literature Conclusion .................................................... 31

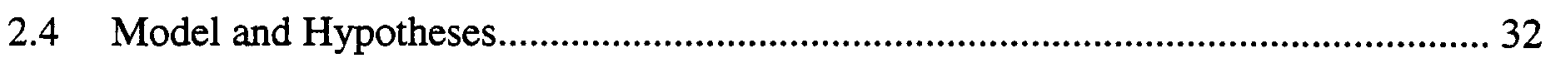

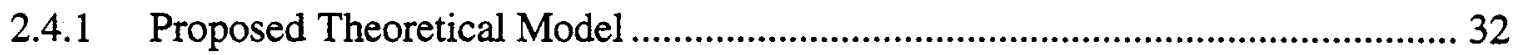

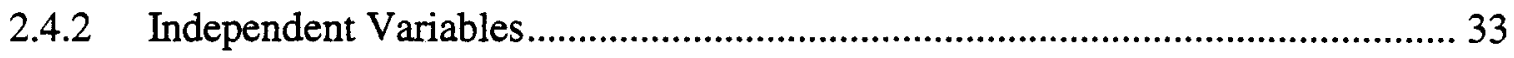

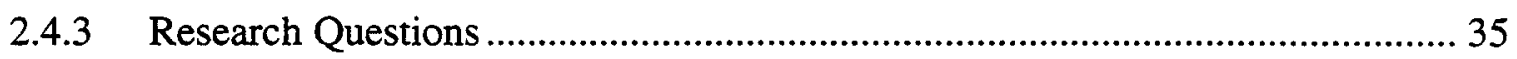

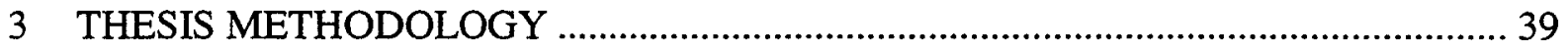

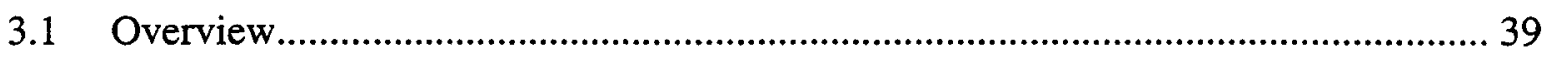

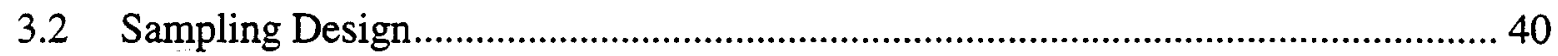

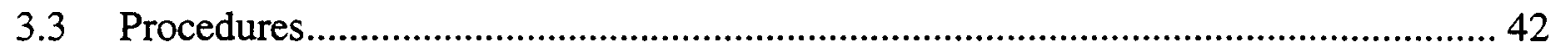

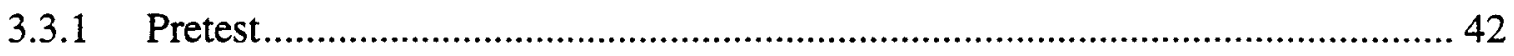

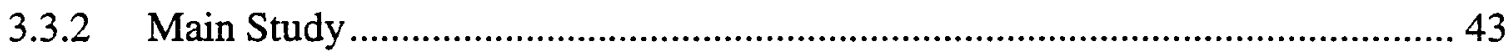

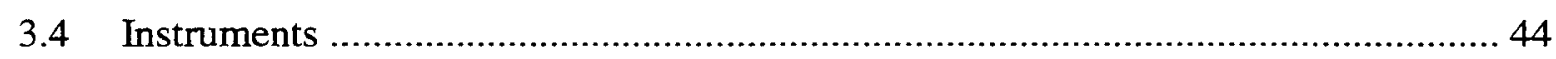

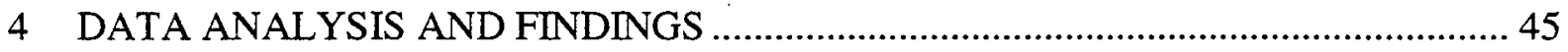

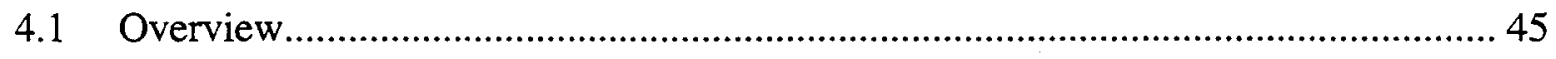

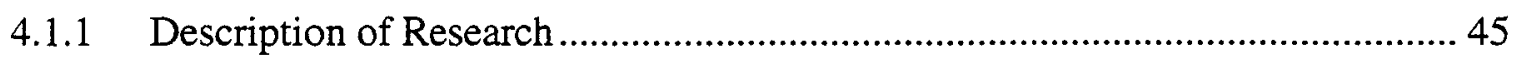


4.1.2 Description of Participating Organizations ......................................................... 46

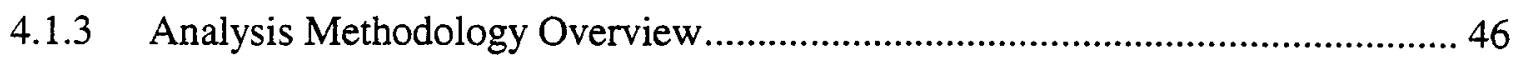

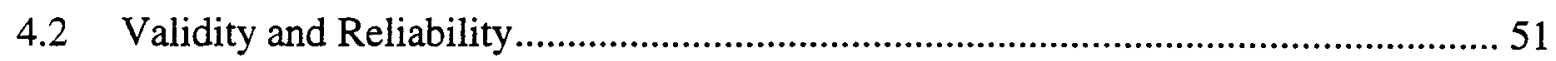

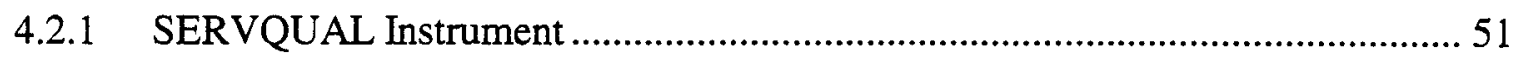

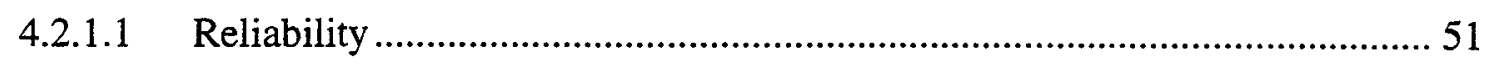

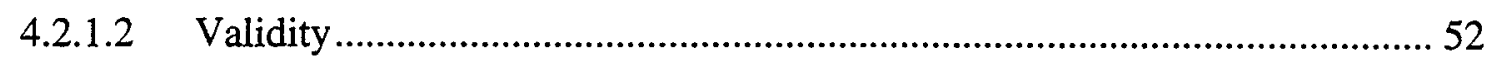

4.2.1.3 Perception Only Model versus Gap Model ................................................. 54

4.2.2 Reliability of User Information Satisfaction Instrument ................................... 55

4.2.3 Reliability of End User Sophistication Instrument ............................................ 55

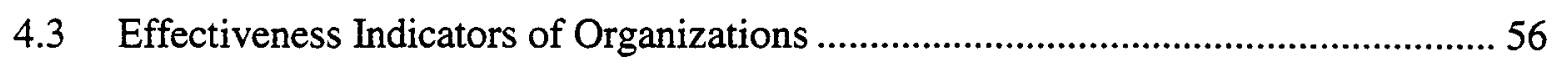

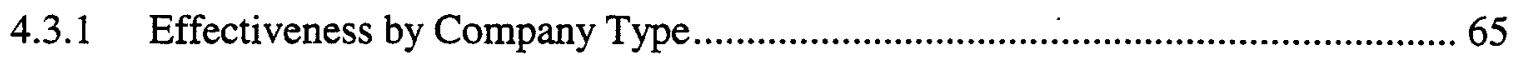

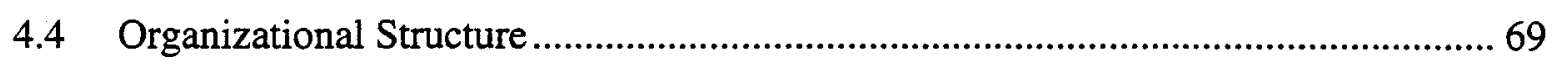

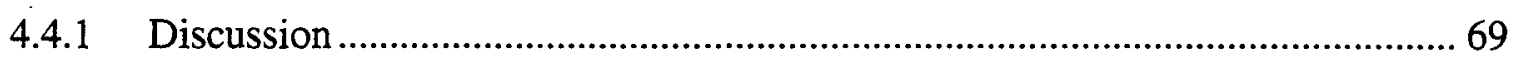

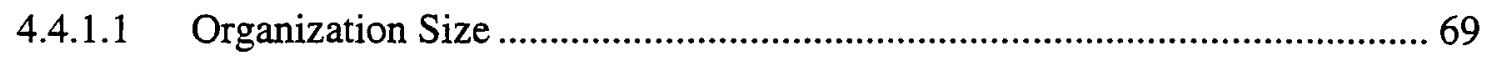

4.4.1.2 Centralization / Decentralization................................................................ 73

4.4.1.3 Support Department Structure ................................................................ 75

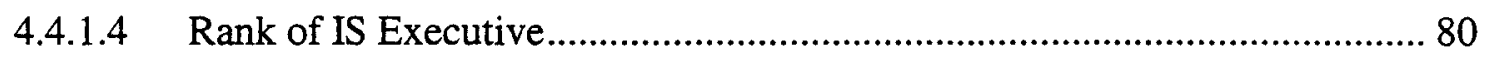

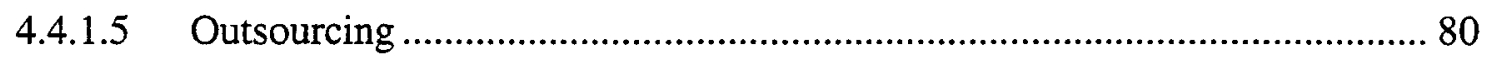

4.4.2 Summary of Organizational Structure Hypotheses .......................................... 85

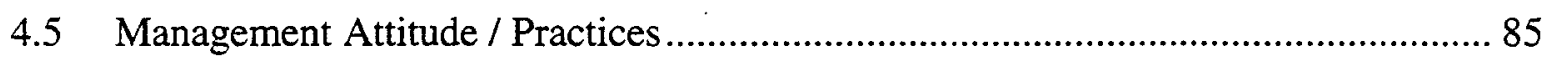

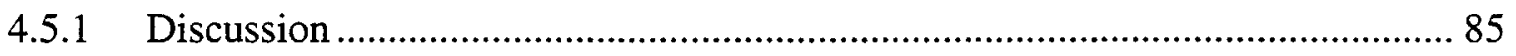

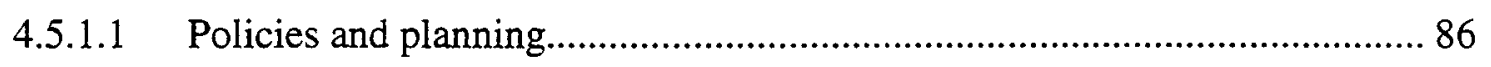




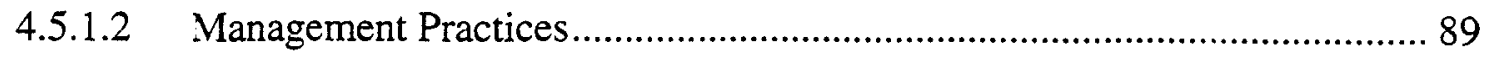

4.5.2 Summary of Management Practices Hypotheses ........................................... 125

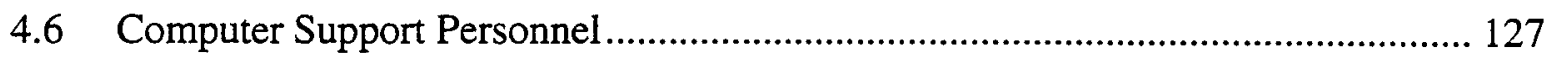

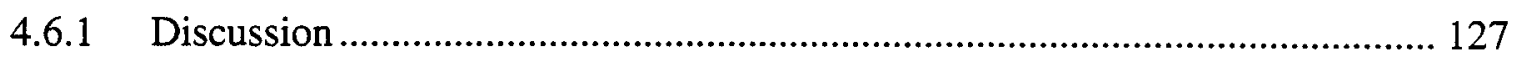

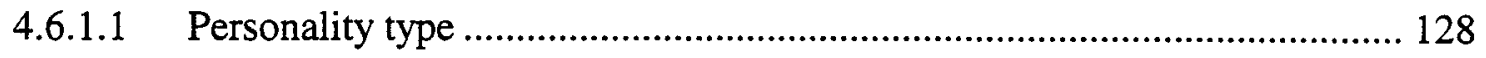

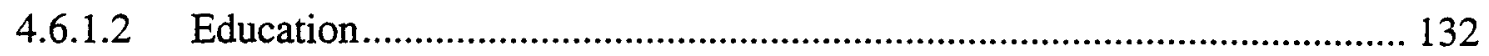

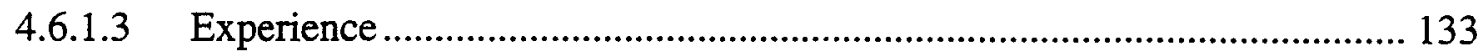

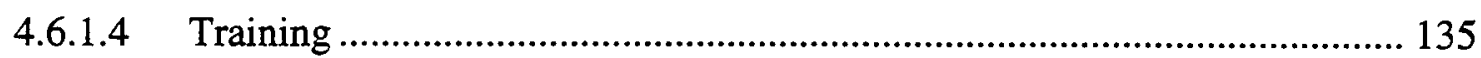

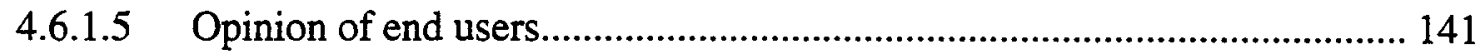

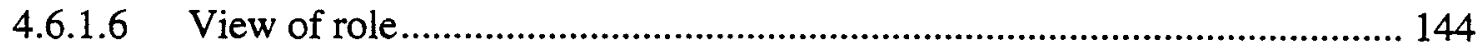

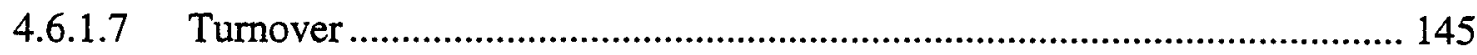

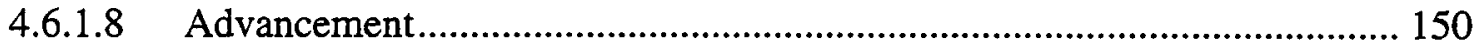

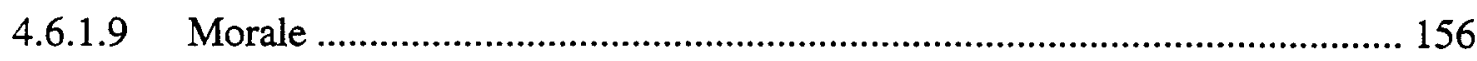

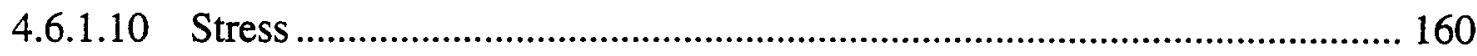

4.6.1.11 Job satisfaction / motivation ...................................................................... 163

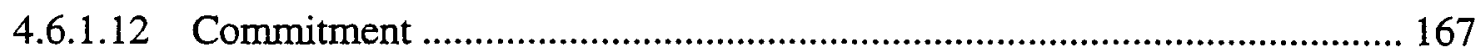

4.6.1.13 Communication between Support Personnel and IS Management ............ 168

4.6.2 Summary of Support Personnel Hypotheses .................................................. 171

4.7 End User Experience/Needs ...................................................................... 172

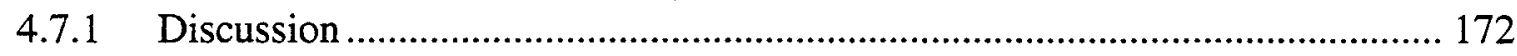

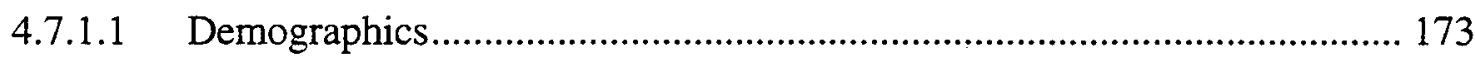

4.7.1.2 Computer skill level ......................................................................... 174 


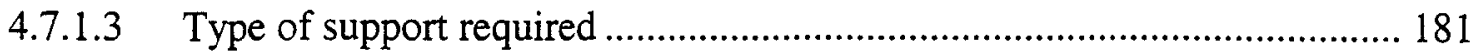

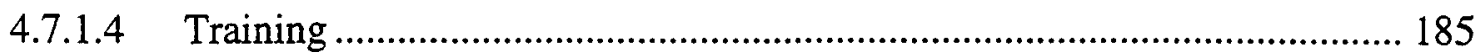

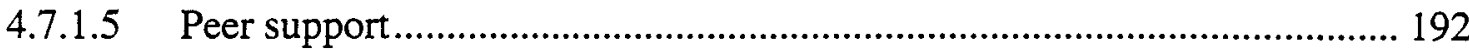

4.7.1.6 Communication between IS and End Users ........................................... 194

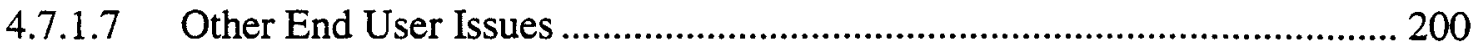

4.7.2 Summary of End Users Hypotheses............................................................ 202

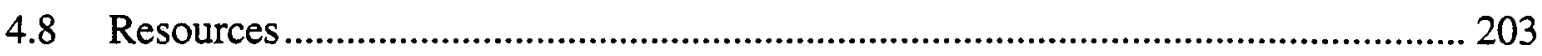

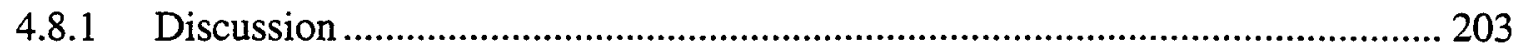

4.8.1.1 Equipment / Products ............................................................................. 203

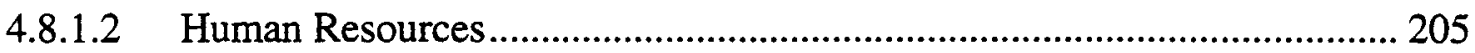

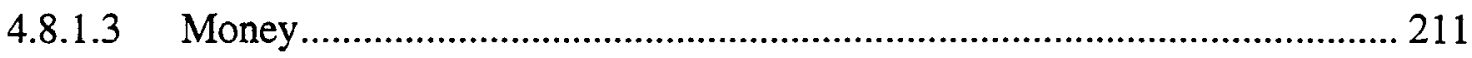

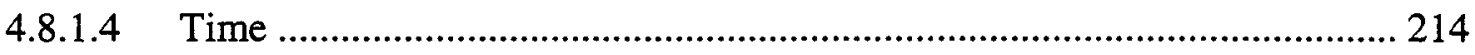

4.8.2 Summary of Resources Hypotheses ........................................................... 216

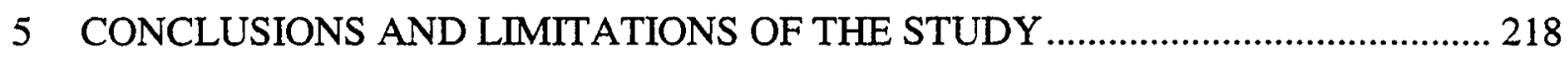

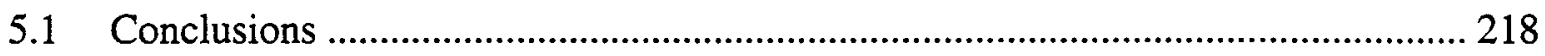

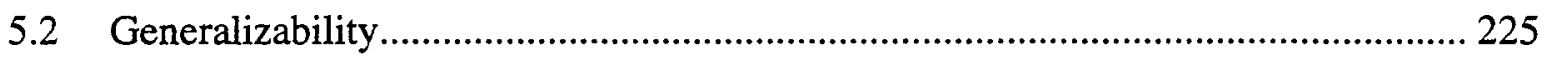

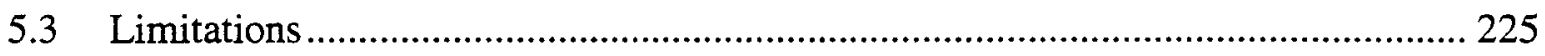

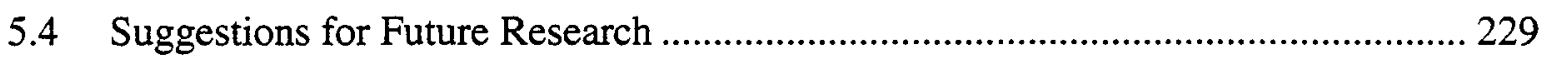

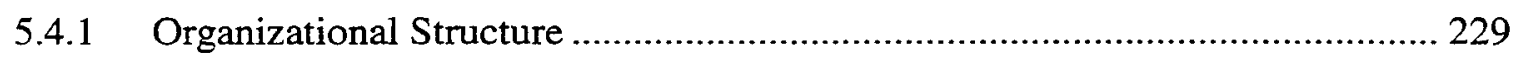

5.4.2 Management Attitudes / Practices.................................................................. 231

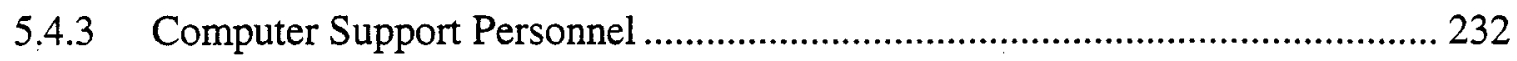

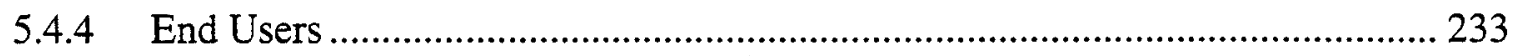




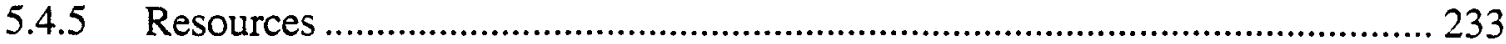

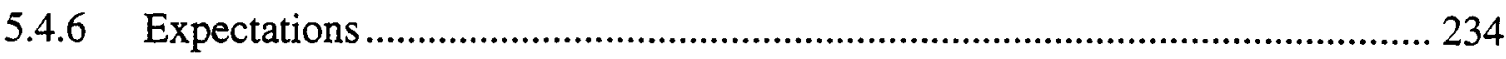

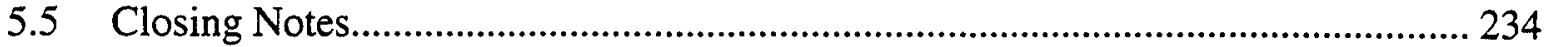

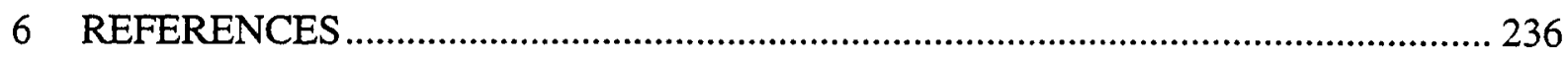

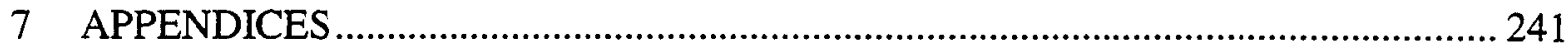

Appendix 1: Management Interview Questions .............................................................. 241

Appendix 2: Support Personnel Interview Questions........................................................ 244

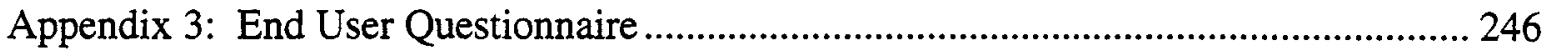

Appendix 5: Letter to Prospective Participants ............................................................ 267

Appendix 6: Instrument Evaluation Details ................................................................ 268 


\section{LIST OF FIGURES}

FIGURE 1: THEORETICAL MODEL 34

FIGURE 2: ORGANIZATION EFFECTIVENESS CLASSIFICATION 63

FIGURE 3: ORGANIZATIONAL STRUCTURE \& MANAGEMENT 220 PRACTICES FINDINGS

FIGURE 4: SUPPORT PERSONNEL, END USERS \& RESOURCE FINDINGS

FIGURE 5: REVISED THEORETICAL MODEL 


\section{LIST OF TABLES}

TABLE 1: ORGANIZATIONAL SERVICE ISSUES

TABLE 2: ORGANIZATIONAL STRUCTURE REFERENCES

TABLE 3: MANAGEMENT REFERENCES

TABLE 4: COMPUTER SUPPORT PERSONNEL REFERENCES

TABLE 5: END USER REFERENCES

TABLE 6: EFFECTIVENESS RATINGS BY ORGANIZATION

TABLE 7: STATISTICAL SIGNIFICANCE BETWEEN ORGANIZATIONS

TABLE 8: EFFECTIVENESS RATINGS BY ORGANIZATION

TABLE 9: ORGANIZATION EFFECTIVENESS CLASSIFICATION

TABLE 10: EFFECTIVENESS RATING BY COMPANY TYPE

TABLE 11: STATISTICAL SIGNIFICANCE BETWEEN COMPANY TYPES

TABLE 12: SUPPORTED USER BASE AND EFFECTIVENESS

TABLE 13: CENTRALIZATION BREAKDOWN

TABLE 14: USER SUPPORT CONTACT MECHANISM

TABLE 15: USE OF OUTSOURCING IN ORGANIZATIONS

TABLE 16: OUTSOURCING / CONTRACTING TYPE

TABLE 17: INFORMATION TECHNOLOGY PLAN

TABLE 18: ORGANIZATIONAL POLICIES

TABLE 19: PROACTIVE - STANDARD TECHNOLOGY CONFIGURATION

TABLE 20: PROACTIVE - USER INVOLVEMENT

TABLE 21: TECHNOLOGY STANDARDS AND TIME

TABLE 22: SERVICE ORIENTATION BREAKDOWN

TABLE 23: EDUCATION VERSUS EXPERIENCE 
TABLE 26: PROBLEM MONITORING COMMENTS

TABLE 27: REPORTS OF GOOD / BAD MANAGEMENT

TABLE 28: COMMUNICATION BETWEEN UPPER MANAGEMENT AND IT

TABLE 29: COMMUNICATION BETWEEN IS DEPARTMENTS

TABLE 30: AVERAGE SUPPORT PERSONNEL AGE

TABLE 31: EDUCATIONAL BACKGROUND

TABLE 32: AVERAGE IS EXPERIENCE OF INTERVIEWED SUPPORT PERSONNEL

TABLE 33: COMPUTER SUPPORT PERSONNEL TRAINING

TABLE 34: TRAINING ISSUES

TABLE 35: ALTERNATE FORMS OF TRAINING

TABLE 36: COMPUTER SUPPORT PERSONNEL TRAINING COMMENTS

TABLE 37: END USER OPINIONS

TABLE 38: SUPPORT REPRESENTATION

TABLE 39: SUPPORT STAFF TURNOVER

TABLE 40: TURNOVER REASONS

TABLE 41: RETENTION REASONS

TABLE 42: ADVANCEMENT - MOVEMENT

TABLE 43: ADVANCEMENT - CAREER

TABLE 44: SUPPORT PERSONNEL MORALE

TABLE 45: JOB UNCERTAINTY

TABLE 46: STRESS

TABLE 47: SUPPORT PERSONNEL JOB SATISFACTION

TABLE 48: OVERTIME

TABLE 49: COMMUNICATION BETWEEN SUPPORT PERSONNEL AND IS MANAGEMENT 
TABLE 52: IS SUPPORT CALL FREQUENCY

TABLE 53: TYPE OF SUPPORT REQUTRED

TABLE 54: USER TRAINING

TABLE 55: TRAINING - SUPPORT RELATIONSHIP

TABLE 56: TEACHING USERS NEW SKILLS

TABLE 57: TIME ISSUES WITH TEACHING USERS

TABLE 58: FREQUENCY OF IS AND PEER SUPPORT

TABLE 59: USER SATISFACTION WITH PEER SUPPORT

TABLE 60: COMMUNICATION BETWEEN IS AND END USERS

TABLE 61: END USER COMMUNICATION ISSUES

TABLE 62: END USER MORALE

TABLE 63: EQUTPMENT / PRODUCT RESOURCE ISSUES

TABLE 64: LACK OF STAFF

TABLE 65: OTHER STAFFING ISSUES

TABLE 66: MONEY RESOURCE ISSUES

TABLE 67: TIME RESOURCE ISSUES

TABLE 68: SERVQUAL INSTRUMENT RELIABILITY

TABLE 69: SERVQUAL EXPECTATIONS INSTRUMENT RELIABILITY

TABLE 70: CONVERGENT VALIDITY

TABLE 71: SERVQUAL DIMENSIONS 


\section{INTRODUCTION}

\subsection{Management Problem and Importance}

Understanding the factors that influence the success of information systems in organizations is important to the successful management of organizations. A great deal of research attention has focused on identifying such factors (see Delone \& McLean 1992 for a comprehensive review) so that success can be enhanced.

One such factor repeatedly identified as essential was the provision of adequate end user support (e.g., Igbaria, 1990; Mirani \& King, 1994; Nelson et al, 2000). However, in spite of its acknowledged importance, relatively little research has focused on the most effective ways to structure the end user support organization. There was also evidence that we don't fully understand the concept of computer support. Compeau \& Higgins (1995) performed a study on Computer Self-efficacy (an individual's belief about his/her own abilities to competently use computers). They found that computer support had a negative influence on self-efficacy and an individual's expectations of the outcomes of using computers when a positive influence had been expected.

This thesis examined the management problem of how organizations can provide effective computer support. How were organizations providing computer support and how effective were their efforts? What factors influenced the quality of service provided by the support function? What distinguished an organization where the users were satisfied with their current level of support from one where the users were dissatisfied? 


\subsection{Relevant Literature}

The literature relevant to the computer support function was extracted from two sources: the IS literature and the service quality literature.

The IS literature was quite diverse and many variables surfaced which may impact the effectiveness of the computer support function. These variables pertained to the following categories: organizational structure, management, IS personnel, end users, and resources. The user information satisfaction instrument seemed viable as one measure of computer support effectiveness but an additional measure from the service quality literature was used to view effectiveness from a different point-of-view.

There have been several definitions of quality used in the service quality literature. The most predominant definition in the services marketing literature applicable to the computer support question was that quality was meeting and/or exceeding customer's expectations. In the case of computer support, the customers are the end users. This definition enables the user to provide their viewpoint on the service (i.e., computer support) received. The unique attributes of service presented several management and service personnel issues that potentially impacted service quality. Parasuraman, Zeithaml, and Berry (1985, 1988, 1991, 1993, 1994a, 1994b) developed a generic instrument, SERVQUAL, for measuring service quality based on this definition. SERVQUAL was been validated in many organizational setting including the Information Systems context (Pitt et al. 1995, Van Dyke et al. 1997, Pitt et al. 1997, Kettinger and Lee 1997, Watson et al. 1998). 


\subsection{Research Questions}

The following research questions addressed how companies perform computer support and how effective is that support:

1. How do different organizations structure their IS departments with respect to the computer support function?

2. How does the organizational structure of the IS department influence the effectiveness of the computer support function?

3. What management attitudes / practices influence the effectiveness of the computer support function?

4. What computer support personnel attitudes / practices influence the effectiveness of the computer support function?

5. What are the end user experience / needs with respect to the computer support function?

6. What is the impact of the availability of resources on the effectiveness of the computer support function?

\subsection{Methodology}

This study was exploratory in nature and consisted of a cross-sectional, field study. The goal was to obtain a broad view of how computer support was being delivered and what factors seemed to influence its effectiveness. Interviews and questionnaires 
were used to collect data from managers, support providers, and end users. The unit of analysis was the firm.

A literature review along with preliminary interviews of management of selected companies were used to prepare and validate research and interview questions pertaining to the computer support function and its effectiveness.

The main study consisted of an examination of the computer support function in twelve organizations. These mini case studies consisted of management interviews, computer support personnel interviews, and end user surveys. The interviews were done to obtain management and support personnel's views on management practices and procedures, various affective concerns (i.e. morale, intention to quit), and obstacles encountered in their job (i.e. lack of time, resources). The end user surveys were conducted to determine their opinion of the effectiveness of the computer support function.

\subsection{Contributions}

The benefits of this research are applicable to both managers and researchers. This study provides guidance to managers on how to provide effective computer support through its comparison of different support implementations, what worked and what did not work, and tradeoff decisions to be made. This study also provides researchers a model of computer support and possible hypotheses for future research. 


\subsection{Overview of Document}

The remainder of this document presents a literature review on relevant topics (Chapter 2), describes the theoretical model and research questions examined, outlines the proposed methodology (Chapter 3), describes the analysis and findings of the study (Chapter 4), and presents the conclusions and limitations of the study (Chapter 5). 


\section{LITERATURE REVIEW}

\subsection{Overview}

Computer support is a service provided by the IS department or function to assist users in the use of computing technology, including software, hardware, and networking. Front-line or $1^{\text {st }}$ level support represents support personnel who have the most direct user contact. They are the first people the users contact whenever they have any type of computer-related problems. For example, $1^{\text {st }}$ level support could take the form of a help desk or hot-line call center or the first contact person on-site to assist a user with resolving a problem. $2^{\text {nd }}$ level and $3^{\text {rd }}$ level support are subsequent levels of support providing more depth of knowledge on particular problem areas (e.g,. application, network). Although there is still user contact involved in these positions, it is less frequent than in the front-line positions.

Computer support effectiveness, in the context of this study, is how well the computer support function is provided, as judged from the organizational perspective, within an organization.

There were two general bodies of literature relevant to the effectiveness of the computer support function: Information Systems literature and Service Quality literature. The Information Systems (IS) literature covered various organizational structure, management, IS personnel, end user, and resource issues relating to the support of computer use within organizations. The IS literature also included the measurement of 
Information Systems effectiveness. The Service Quality literature dealt with service attributes, quality definitions, management and service personnel issues, service quality measurement, and the relationship between service quality and consumer satisfaction.

The following two sections describe the Information Systems and Service Quality literature used to create the initial theoretical model for computer support effectiveness examined in this study.

\subsection{Information Systems Literature}

There have been many different topics explored in the Information Systems literature. In examining the computer support function, this study was interested in the process of how organizations and IS departments in particular help end users solve their computing problems. This review of the IS literature focused on the user and the process of supporting user needs. The end user computing (EUC) literature dealt with many user and support issues as did other literature examining Information Systems from different perspectives. Information Centers (ICs) were created to support end-user computing in organizations and have been examined in various studies (e.g., Mirani \& King, 1994; Carr, 1987; Magal et al. 1988). Magal et al. (1988) examined critical success (CSFs) for IC managers and found that the most important CSF was the quality of IC support services. The user information satisfaction (UIS) literature looked at a way measuring IS systems success with a user orientation. All of these topics are examined in the IS literature section. 
There were a number of articles published on end-user computing (EUC) in the IS literature. See Brancheau and Brown (1993) for a comprehensive examination of articles published from 1983 to 1990 . Brancheau and Brown defined end-user computing as "the adoption and use of information technology by personnel outside the information systems department to DEVELOP software applications in support of organizational tasks" although a study by McLean and Kappelman (1992-1993) found that end user computing has become a direct extension of corporate computing "indistinguishable by type of application or by size or type of hardware". This study adopts the latter definition and focuses on all users who use computing facilities and not only users who develop applications.

Bergeron et al. (1990) investigated the relationship between features of the IC support role (IC staff, location, services, software tools, and budget) and user satisfaction. Their study used factual measures instead of perceptual measures and obtained data from both users and IC managers. Their results indicated a negative correlation existed between user satisfaction and the following variables: the number of IC employees, the number of databases, and the number of software tools provided to users. A positive correlation was found between user satisfaction and the following variables: the proximity of the IC, the diversity of services offered, and the proportion of the information systems budget devoted to the IC. The variables representing IC staff did not include people-orientation and cooperativeness dimensions that could lead additional insight into the support function. 
Many variables surfaced in the IS literarure possibly impacting the effectiveness of the computer support function. These variables appeared to deal with the following categories: organizational structure, management, computer support personnel, end users, and resources. The intent of this review was to come up with a thorough list of factors that may impact computer support effectiveness to use as part of a baseline theoretical model for investigation in this study. Literature on IS effectiveness was also examined.

\subsubsection{Organizational Structure}

Organizational structure referred to how the computer support function was organized. The support function could be centralized or decentralized. Various types of systems could be supported by one or several departments. Users could contact a help desk or directly call the support personnel. The support function could report to the Information Services (IS) department or to the users directly. Halloran (1993) found there were weak organizational structures in place in many organizations for dealing with the EUC environment. There were several aspects of organizational structure that may impact the effectiveness of the computer support function.

Patching (1989) stated that the two main reasons for creating a formal structure within an Information Center was to tell users how they will be helped in their various demands for services and to help clarify internally who is responsible for what. If the support personnel did not know their responsibilities, the quality of service was affected. Karten (1994) described the results of an assessment that an IS division of a major bank 
did on the perceptions of its internal customers and found that customers frequently did not know who, in IS, to call when they experienced problems. Cheney et al. (1986) proposed that the rank of the executive responsible for the end user computing facility may affect the likelihood of its success.

\subsubsection{Management}

Various articles examined different aspects of the management of Information Systems. Organizational policies and planning, management practices, and communication could all have a potential impact on the effectiveness of the computer support function.

\subsubsection{Policies and Planning}

The literature indicated that organizational policies and planning impacted the effectiveness of the IS unit. Cheney et al. (1986) proposed that the establishment of corporate policies covering the creation and operation of the end user computing facility may affect the likelihood of its success. Lederer and Mendelow (1987) found that information resource managers encountered problems identifying top management's objectives due to formulation difficulties (i.e. firm did not have a strategic plan). Nelson et al. (2000) found that IS policy (e.g., hiring, training, performance evaluation) in mature IS departments had a direct relationship on IS group outcomes. 


\subsubsection{Management Practices}

Various management practices have been researched in the IS literature. Halloran (1993) found that there were poorly defined management practices and a lack of role definition in the support of the EUC environment. An organization might focus on products as opposed to service that might influence the service quality. The degree of reactive versus proactive support might also have an effect (Patching, 1989). If management does not attempt to decrease the need for support in the future, the amount of reactive support required might be too great to be performed adequately. Arnoudse \& Ouellette (1986) stated that the IC's first priority is to focus on users' business goals and related information needs (i.e. to be user rather than technology oriented).

The importance of selecting the right IS personnel (Patching, 1989) was stressed so the hiring practices of management could affect the quality of service. Murray (1996) stated that customer service also includes measuring and monitoring productivity and quality in the IS department as well as developing communication processes to inform people of what is being done in the IS department. If management does not monitor quality or hire the correct support personnel, service quality might be affected. Lee et al. (1995) suggested that organizations could offer different career tracks for IS professionals each having a different emphasis on the multidimensional knowledge/skills. Managers must also have realistic expectations or they might hinder the success of the end user computing facility (e.g. Cheney et al, 1986). 


\subsubsection{Communication}

Communication problems between top management and IS management as well as within IS departments could impact service quality. Lederer and Mendelow (1987) found that Information Resource managers had problems identifying top management's objectives due to communication difficulties (i.e. top management lacks IS understanding). Karten (1994) found users felt there were communication problems among IS departments which resulted in a lack of awareness of the support each of several IS departments was providing to a given customer area. This was supported by Nelson and Cooprider (1996) who examined the concept of shared knowledge between IS and line organizations as a contributor to IS performance. They found that "shared knowledge mediates the relationship between IS performance and trust and influence and that increasing levels of shared knowledge between IS and line managers leads to increased IS performance".

\subsubsection{Computer Support Personnel}

The importance of IS personnel was emphasized in the IS literature (Patching 1989, Lee 1986). White Jr. \& Christy (1987) identified a need for personnel highly sophisticated in the EUC support area. Computer support personnel required different skills and knowledge to effectively support computer use. They must be able to communicate and understand the needs of end users. The quality of work life as well as 
other affective reactions (i.e. stress, morale) could also affect the ability of the personnel to effectively deliver good support.

Nelson et al. (2000) used causal mapping to investigate software operations support expertise. One of the major constructs they found was personal competencies which included: cognitive abilities, general IS related abilities, technical competencies, business application competencies, context specific competencies, social competencies, and mode of knowledge acquisition. The mix of technical and people oriented skills that computer support personnel possess might be an influencing factor on the effectiveness of the support. Patching (1989) stated that a mix of business and technology skills are required in an Information Center. Carr (1987) found that eighty percent of surveyed IC managers indicated the user support was a prime duty and that many staff characteristics were important to the success of an IC. The most important characteristics were found to be a user orientation and an understanding of the user's problems and needs, "followed by a reasonable technical background but possessing the view of a generalist, and the personal characteristics of patience, flexibility, and creativity" (Carr, 1987, page 330). Arnoudse \& Ouellette (1986) felt that IC staff members must learn to be expert consultants who work with the users as opposed to technical gurus who tell users what to do or technicians who do as users dictate. Lee et al. (1995) found that IS graduates who plan to work in the central IS organization might require "in-depth knowledge of specific technologies as well as possess a broad technology management background". IS 
graduates who planned to work in user areas might require a solid background in human relations and business management.

Miriani and King (1994) suggested the formation of user groups be aided by IC staff if the staff did not possess the required skills to assist highly advanced users so that users with similar support needs could help one another.

How support personnel viewed end-users and their own role as a support personnel could also impact the service quality. Nelson (1991) found that IS personnel needed better general IS knowledge and improved organizational knowledge. He recommended that IS and end user personnel be educated to make each more sensitive to the other's problems. This implied that the communication between the support personnel and end user was extremely important. St. Clair (1993) stated that the information professional is the link between management and the users. He emphasized the users are major stakeholders in the management of information and without them there would be no need to manage (and support) information. If support personnel did not realize the importance of the end user then service quality might be affected.

Other possible influences on the quality of service could be the experience and education of support personnel; employee turnover (Hussain, 1992; Igbaria \& Greenhaus, 1992) and advancement (Patching, 1989); stress (Hussain, 1992); motivation / commitment of employees (Nelson et al., 2000; Igbaria et al., 1994); quality of work life (job satisfaction, career satisfaction, organizational commitment) and job involvement (Igbaria et al., 1994). Cheney et al. (1986) proposed that the realism of information 
systems professionals' expectations could affect the success of an end user computing facility.

\subsubsection{End Users}

End users had different skill levels (novice, intermediate, expert), required different types of support (i.e. installation, troubleshooting), and had different reasons for requiring support (i.e. lack of training, equipment failure). The experience and needs of the end users could impact the perceived quality of service provided.

Mirani and King (1994) found that the support needed by end users varied with their computing sophistication but all users were provided with the same amount of support. They found that end-user satisfaction was higher if more end-user support needs are fulfilled. Nelson (1991) found that end users need improvement in general IS knowledge as well as improved technical and IS-related skills. As mentioned in the computer support personnel section, he recommended that there is a need to educate IS and end user personnel to make each more sensitive to the other's problems. Cheney et al. (1986) proposed the availability of end user training and the realism of expectations of end users may affect the likelihood of the success of an end user computing facility.

Lee (1986) found that most users needed a considerable amount of information and help in order to use computers proficiently. He also found that the best source of information for PC users were their own colleagues with the information systems staff coming in second. Karten (1994) found that many customers ignored the extremely busy 
help desk and relied on other customers to help them with problems. The use of colleagues for computer support has many implications. Halloran (1993) found that a lack of well defined management practices and management infrastructure resulted in high "peer support" costs. The end users who supported their co-workers may spend much of their time performing support and not completing their regular work. Putting support personnel in the user areas might improve communication and help IS better understand user needs and the users' day-to-day tasks leading to improved service quality. This could result in high organizational costs if there are many diverse user areas. Training user representatives in IS areas and/or improving the communication and access to support personnel could be another alternative.

\subsubsection{Resources}

Although the structure of the support function might be well organized, the support personnel well managed, and the importance of the user needs well understood, the service quality would be impacted if there were insufficient resources. Resources were categorized into: time, money, personnel, equipment/products, and training/development. Cheney et al. (1986) proposed that the size of the existing systems development backlog of projects may affect the likelihood of the success of an end user computing facility. White Jr. \& Christy (1987) identified that a major IC implementation problem was that there was user demand for new and more sophisticated services and a lack of resources to meet the demand. 


\subsubsection{Information Systems Effectiveness}

Delone \& McLean (1992) developed a process model showing MIS success as a multidimensional construct with six success categories: system quality, information quality, use, user satisfaction, individual impact, and organizational impact. The current study was interested in the process of supporting computer users so the most relevant of the success categories was the user's perception of satisfaction. One particular user satisfaction instrument, User Information Satisfaction (UIS), was frequently used and tested (e.g., Ives et al., 1983; Baroudi \& Orlikowski, 1988; Galletta \& Lederer, 1989). UIS was defined as "the extent to which users believe the information system available to them meets their information needs" (Ives et al., 1983). Melone (1990) noted that although the UIS construct was used extensively in MIS research, there has not been sufficient attention to the theory behind it and its relationship with other constructs. Kettinger \& Lee (1994) renamed UIS as USISF (user satisfaction with the Information Services function) to improve the conceptual clarity and to focus the measure on an assessment of an organization's information services function. They felt that the UIS instrument was not comprehensive enough and tested if some dimensions of SERVQUAL ${ }^{1}$ could be used to supplement the service dimension. They found that the three original dimensions of the traditional UIS measure (quality of information products,

1 Service quality instrument developed by Parasuraman et al. (1988, 1991). See Service Quality Literature section for more details. 
level of user's knowledge and involvement, and attitude towards EDP staff and services (Baroudi \& Orlikowski, 1988), as well as two dimensions of IS service quality (reliability and empathy) were all significant predictors of overall user satisfaction with the Information Services Function.

Doll \& Torkzadeh (1988) developed an instrument that measured five components of end user satisfaction (content, accuracy, format, ease of use, and timeliness). This instrument measured a user's satisfaction with a particular application instead of general user satisfaction with EDP staff and services, information product, and user involvement / knowledge. The end-user satisfaction instrument was inappropriate for the current study as it dealt with a service function (i.e. computer support) and not a single application. The current study used the USISF instrument as one measure of the effectiveness of the computer support function due to its applicability and past use in the IS context and adopted an additional measure from the service quality literature, as in Kettinger \& Lee (1994), to look at computer support effectiveness from a services point-of-view.

\subsubsection{Information Systems Literature Conclusion}

The IS literature was quite diverse and many variables surfaced potentially impacting the effectiveness of the computer support function. These variables pertained to the following categories: organizational structure, management, IS personnel, end users, and resources. None of the organizations participating in the study were in the business of selling computer-related technology, so from this standpoint, computer 
support, and IS in general, is not considered core business. From an organizational perspective, the users are the customers in the computer support equation and are in the best position to evaluate if the computer support received met their business needs. User information satisfaction along with a service quality measure will be used to provide a user-based view of computer support effectiveness.

\subsection{Service Quality Literature}

The second body of literature examined is service quality which originated in the Marketing literature. Please refer to Fisk et al. (1993) for a look at the evolution of the services marketing literature from 1953 to 1992 . Service quality literature has dealt with many issues including the unique attributes of service, the definition of quality, management and service personnel practices and procedures, the measurement of service quality, and the relationship between service quality and consumer satisfaction.

\subsubsection{Service Attributes}

Services have unique attributes that differentiate them from products. Unique service characteristics consistently cited in the marketing literature were intangibility, heterogeneity, inseparability of production and consumption, and perishability (Zeithaml et al., 1985; Fisk et al., 1993). Services were intangible because they are not objects but performances so precise manufacturing specifications concerning uniform quality cannot be set (Parasuraman et al., 1985). Services were heterogeneous because they can vary from day-to-day, service provider to service provider, and consumer to consumer. There 
was potential for high variability in the performance of services (Zeithaml et al., 1985). Services are usually sold first, then produced and consumed simultaneously because they can not be inventoried (Bowen \& Schneider, 1988). Services were perishable because they cannot be saved (Zeithaml et al., 1985). Bowen \& Schneider (1988) also added that services are frequently associated with customer participation. These attributes resulted in unique organizational problems discussed in the below management section.

\subsubsection{Definition of Quality}

Reeves \& Bednar (1994) investigated the definition of quality. The authors felt that "definitional difficulties account for many of the inconsistent and often contradictory empirical results found in the extant literature". An extensive literature search was done to examine the root and history of quality definitions. These definitions are:

- Quality is excellence

- Quality is value

- Quality is conformance to specifications

- Quality is meeting and/or exceeding customer's expectations.

The authors concluded there was not one good definition of quality that worked in every situation. Managers and researchers should state which quality definition they are using and recognize its strengths and weaknesses. The definition of quality as the degree to which a product or service meets and/or exceeds a customer's expectations grew out of the services marketing literature. The strengths of this definition of quality were that it 
evaluates from customer's perspective, is applicable across industries, is responsive to market changes, and is an all-encompassing definition. The weaknesses of this definition of quality were: it is the most complex definition; it is difficult to measure; customers may not know expectations; customers may have idiosyncratic reactions to different experiences making it difficult to make predictions; pre-purchases attitudes may affect subsequent judgments; short-term and long-term evaluations may differ; and confusion exists between customer service and customer satisfaction. Despite these weaknesses, this definition allowed managers and researchers to include subjective factors (e.g., courtesy) that are important to customers' judgments but difficult to measure in assessments of service quality. This definition seemed the most relevant to the computer support function and will be used to define service quality.

\subsubsection{Management}

Bowen \& Schneider (1988) looked at services marketing from an organizational behavior point of view and described problems encountered by organizations due to the aforementioned unique service attributes and suggested ways that organizations can face these problems. See Table 1 for the kinds of issues organizations must manage to be effective (extracted from Bowen \& Schneider, 1988). These issues brought about possible management problems in the delivery of effective computer support (e.g.,. monitoring service quality, coordinating resources, communication, recruitment, training, user participation). 


\begin{tabular}{|c|c|c|}
\hline $\begin{array}{l}\text { SERVICE } \\
\text { ATTRIBUTES }\end{array}$ & $\begin{array}{l}>\text { ORGANIZING } \\
\text { CONTINGENCIES }\end{array}$ & -> ORGANIZING PRINCIPLES \\
\hline Intangibility & $\begin{array}{l}\text { Limited objective reference } \\
\text { points for assessing value of } \\
\text { services } \\
\text { Difficult to quantitatively } \\
\text { measure output and service } \\
\text { quality } \\
\text { Difficult to set specific goals } \\
\text { for employees }\end{array}$ & $\begin{array}{l}\text { Enhance climate for service for } \\
\text { employees and customer }\end{array}$ \\
\hline $\begin{array}{l}\text { Simultaneous } \\
\text { Production and } \\
\text { Consumption }\end{array}$ & $\begin{array}{l}\text { Difficult to decouple } \\
\text { production and marketing; } \\
\text { performance of employees in } \\
\text { front-line, boundary spanning } \\
\text { roles significantly affects } \\
\text { organizational effectiveness } \\
\text { Difficult to coordinate the } \\
\text { supply and demand of services } \\
\text { Front-line employees possess } \\
\text { information about customer } \\
\text { attitudes and preferences }\end{array}$ & $\begin{array}{l}\text { Evaluate customer participation as one } \\
\text { mechanism for meeting supply of } \\
\text { services } \\
\text { Utilize participative decision making; } \\
\text { implement "service quality circles }\end{array}$ \\
\hline $\begin{array}{l}\text { Customer } \\
\text { Participation }\end{array}$ & $\begin{array}{l}\text { Difficult to buffer core } \\
\text { technology from input } \\
\text { uncertainties posed by } \\
\text { customers } \\
\text { Customer behavior may need to } \\
\text { be managed in addition to } \\
\text { employee behavior }\end{array}$ & $\begin{array}{l}\text { Establish optimal boundary between } \\
\text { employee and customers } \\
\text { Enhance the motivation, ability, and } \\
\text { role clarity of participating customers }\end{array}$ \\
\hline
\end{tabular}

Table 1: Organizational Service Issues ${ }^{2}$

${ }^{2}$ Bowen \& Schneider, 1988, pages 56-57. 
The attitudes and performance of managers were found to impact service quality in past research. Burke (1995) looked empirically at how various management practices and procedures and affective reactions correlated with perceived quality of service through a survey of employees of a large professional services firm. He found that organizational values, managerial support, and supervisor competence had a significant $(\mathrm{p}<.001)$ correlation with service quality.

Watson et al. (1998) examined Information Systems from a longitudinal perspective. They performed two cases studies where service quality was measured at three different points in the same organization. They found that service quality improved after IS management implemented changes to address issues found in their initial service quality results. For the third measurement, IS service quality actually decreased and returned back to its initial values. Watson et al. concluded this was due to the lack of management attention to service quality in that period. They cautioned that IS management must recognize the need to commit to the service quality process on an on-going basis. Watson et al. (1998) recommended the following steps to help improve service quality:

- Link IT strategy to the business strategy

- Communicate with clients

" Not examined in current study. Refer to section 5.1.3 for recommendations for future research. 
- Design service quality processes ${ }^{*}$

- Training

- Reward systems*

- Building service quality into IS

\subsubsection{Computer Support Personnel Attitudes / Practices}

The importance of service personnel was emphasized in the service quality literature (Mefford 1993, Yoshida 1993). Burke (1995) found that on-the-job development, value of training, intent to quit, morale, job satisfaction, and overall satisfaction with the firm had a significant correlation with service quality. Mittal and Lassar (1996) found that personalization of a service encounter was most important determinant of perceived service quality. They defined personalization as the social content of interaction between service employees and their customers. It concerns the "manager in which service employees related to customers as people - cold and impersonal at the one end to warm and personal at the other."

\subsubsection{Service Quality Measurement}

Parasuraman et al. (1985) determined from the use of focus groups that "a set of key discrepancies or gaps exists regarding executive perceptions of service quality and the tasks associated with service delivery to consumers. These gaps can be major hurdles in attempting to deliver a service which consumers would perceive as being of high quality." 
They defined a gap model where the perceived service quality is a function of the magnitude and direction of the gap between expected service and perceived service. Expected service was defined in the normative sense as what the customer feels the service firms should offer (i.e. desires or wants of the customer). The authors also determined from the focus groups ten key categories of service quality determinants. These dimensions were used as a basis for SERVQUAL, a 22-item instrument for assessing customer perceptions of service quality (Parasuraman et al., 1985, 1988, 1991, 1993, 1994a, 1994b). Five dimensions of service quality (tangibles, reliability, responsiveness, assurance, and empathy) were found. Fisk et al. (1993), in their paper on the evolution of the services marketing literature, stated that "while there is debate regarding the dimensionality of SERVQUAL across industries, and the precise wording of the SERVQUAL items, researchers generally agree that the scale items are good predictors of overall service quality". Carman (1990) replicated and tested the SERVQUAL instrument to investigate certain problems. He found that the SERVQUAL dimensions were stable but that they were not completely generic. He also found that there was a problem with some of the items that were stated in negative form since many respondents seemed to misread the item. The author stated that a major problem with SERVQUAL is the collection and use of expectations data. Parasuraman et al. (1991) refined the original SERVQUAL instrument. They revised the wording to focus on what customers would expect from companies delivering excellent service, removed the negatively worded items, and added direct measures of the importance of the various 
service attributes. They tested the refined SERVQUAL instrument and also compared various replications in the literature. They found consistent support for the reliability, face validity and predictive/concurrent validity for the SERVQUAL results on the five dimensions. They found mixed support for convergent validity and discriminant validity of SERVQUAL. The authors stated that the issue of the usefulness of the expectations scores and the appropriateness of analyzing gap scores was unresolved. Bolton \& Drew (1991) developed a multistage model of how customers with prior experiences and expectations assess service performance levels, overall service quality, and service value. They found that a key determinant of the customers' assessment of service quality was the gap between perceived performance and anticipated performance (disconfirmation). They also found that a customer's assessment of overall service quality and value assessment are directly affected by perceived performance levels. Brown et al. (1993) discussed the problems in conceptualizing service quality as a difference score. They stated that the use of difference scores to measure service quality has the following psychometric problems: poor reliability, low discriminant validity (caused by low reliability and the fact that the difference score is normally highly correlated with one of the component measures), and variance restriction (occurs when one of the component scores is consistently higher than the other component). The authors tested a nondifference score approach to see how subjects' perceptions matched their expectations (i.e. better than expected, worse then expected) as well as the SERVQUAL scale. They found that SERVQUAL exhibited discriminant validity problems, variance restriction 
effects, the distribution of the scores was non-normal, and the perceptions component of SERVQUAL outperformed SERVQUAL in predicting behavioral intentions. The nondifference score measure did not have any of these problems. SERVQUAL's dimensionality also did not replicate. Parasuraman et al. (1993) replied to Brown et al.'s (1993) article stating that the "alleged psychometric deficiencies of the difference-score formulation are not as severe as BCP [Brown et al.] suggests, and that the richer diagnostics of SERVQUAL may more than justify the separate measurement of perceptions and expectations" (page 141). They felt that measuring expectations and perceptions separately gives managers more information on the changes in customers' assessments of service quality (i.e. did expectations increase, perceptions decrease, or both). Cronin \& Taylor (1992) tested service quality in four forms: a performance-based measure (SERVPERF), a performance-based measure weighted by importance, SERVQUAL (performance - expectations), and SERVQUAL weighted by importance. The dimensionality stated by Parasuraman et al. (1988) for SERVQUAL was not found. The unweighted measures were found to be superior then the weighted measures and SERVPERF was found to outperform SERVQUAL.

Other articles debated various problems with the SERVQUAL measure (Teas, 1993; Teas, 1994; Cronin \& Taylor, 1994; Parasuraman et al. 1994a) including conceptual and operational issues with the gap model (perceptions-expectations) perceived service quality model (Teas), the relationship between service quality and consumer satisfaction, and attitude formation (Cronin \& Taylor, 1994). Parasuraman et 
al. (1994b) identified all unresolved issues with service quality measurement and empirically tested three alternative questionnaire formats. The unresolved issues were: the empirical versus diagnostic value of expectations in service quality measurement, the relative merits and demerits of SERVQUAL versus direct measures of the performanceexpectation gap, and the dimensionality of SERVQUAL's items. Expectations were revised conceptually to distinguish desired service and adequate service. The measure of service superiority (MSS) was the difference between perceived service and desired service while the measure of service adequacy (MSA) was the difference between perceived service and adequate service. One of the questionnaire formats used the difference-score formulation and the other two used direct measures of service quality (one with the MSA and MSS scales side-by-side and the other with them in different sections). The direct measures of MSS and MSA were found to have higher predictive power than the difference-score measures but the perceptions-only scale was found to have the highest predictive power. The difference-score format was found to be much less susceptible to response error than the direct measure format. The difference-score format had better diagnostic value as it was able to distinguish a tolerance zone (range of service performance a customer considers satisfactory) and the relative position of the perceived service level where as the direct measures did not have this ability.

Pitt et al. (1995) felt that, due to the significant service component of the information systems function, service quality was missing from Delone \& McLean's (1992) six measures of IS success. They augmented the Delone \& McLean model with 
service quality as an input into the use-user satisfaction constructs. They validated SERVQUAL in the Information Systems area. Although, they found some problems with the discriminant validity because some factors did not appear to be different from one another and with the reliability of the tangibles construct, they concluded that SERVQUAL is "an appropriate instrument for research seeking a measure of IS service quality".

Van Dyke et al. (1997), Pitt et al. (1997), and Kettinger and Lee (1997) debated the use of Pitt et al.'s (1995) use of the IS-context modified version of the SERVQUAL instrument. Van Dyke et al. (1997) discussed issues regarding the "conceptual difficulties [including] the operationalization of perceived service quality as a difference or gap score, the ambiguity of the expectations construct, as well as the unsuitability of using a single measure across different industries." They confirmed that using the perceptionsonly method of scoring was a viable alternative. Neither Pitt et al (1997) nor Kettinger and Lee (1997) disputed the use of the perceptions-only measure. Pitt et al. (1997) felt that its use came at the expense of the diagnostic capability of the expectations component. The perceptions-only measure was used in the current study as the measure of service quality.

\subsubsection{Service Quality - Consumer Satisfaction Relationship}

Considerable research was published in the marketing literature on consumer satisfaction similarly to the large amount of research published in the IS literature on user 
satisfaction. Consumer satisfaction was defined primarily as an affective response to a specific consumptive experience (Gotlieb et al., 1994) whereas user satisfaction is defined as "the extent to which users believe the information system available to them meets their information requirements" (Ives et al., 1983). Since the current study focused on users of computer systems supported/serviced by an internal Information Services representative (generally at no cost) as opposed to a customer purchasing a service from a company, the focus was on the user satisfaction literature and instruments (see section 2.2 for more details).

There was considerable debate in the Service Quality literature concerning the relationship between service quality and consumer satisfaction. Perceived service quality was commonly regarded as a form of attitude while satisfaction is a transaction-specific measure (Cronin \& Taylor, 1992). The two constructs were distinct yet related but there has not been any consensus on how the two constructs related. Gotlieb et al. (1994) found support for a model where disconfirmation of expectations affected perceived quality which, in turn, affected satisfaction. Some studies agreed that service quality impacted satisfaction (Parasuraman et al., 1985, 1988; Cronin \& Taylor, 1992) while others have shown satisfaction impacting service quality (Bolton \& Drew, 1991). As previously mentioned. In the IS literature section, Kettinger \& Lee (1994) found that certain dimensions of service quality were needed along with a traditional IS measure of user satisfaction to determine user satisfaction with the information services function. 
When investigating the effectiveness of the computer support function, both service quality and user satisfaction were relevant. Service quality can be measured to see if the support function is meeting and/or exceeding user expectations. User satisfaction with the information services function can be measured to see the level of satisfaction the users have with the support function.

\subsubsection{Service Quality Literature Conclusion}

Several definitions of quality have been used in the literature. The predominant definition in the services marketing literature most applicable to the computer support question was that quality is meeting and/or exceeding customer's expectations. In the case of computer support, the customers are the end users. The unique attributes of services presented several management and service personnel issues possibly impacting service quality. Parasuraman, Zeithaml, and Berry $(1985,1988,1991,1993,1994 a$, 1994b) developed a generic instrument, SERVQUAL, for measuring service quality based on this definition. SERVQUAL was been validated in many organizational settings including the Information Systems context (Pitt et al. 1995). There was some debate concerning problems with SERVQUAL pertaining to the use of expectations data and a difference-score. As mentioned in the Service Quality section, the perceptions-only measure had the best predictive power when compared to the difference-score and direct measures. 
The current study was interested in comparing organizations according to how they provide support. The perceptions-only measure provided a direct comparison among organizations avoiding the expectations and difference-score problem. The perceptionsonly data was collected using the SERVQUAL instrument that also provided the more diagnostic data on expectations. The expectations data was collected for informational purposes to evaluate if there were significant differences between organizations with respect to service quality expectations.

The IS user satisfaction literature was focused on in the study as opposed to the Marketing consumer satisfaction literature as it seemed more appropriate in the study of computer support.

Based on both the IS and Service Quality literature, a combination of user satisfaction with the information services function and service quality were chosen to represent the effectiveness of the computer support function in this study.

\subsection{Model and Hypotheses}

\subsubsection{Proposed Theoretical Model}

The proposed theoretical model is shown in Figure 1. This model examined the relationship between five categories of independent variables (organizational structure, management attitudes / practices, computer support personnel, end user experience / needs, and resources) and the dependent variable (effectiveness of computer support). Based on the IS and Service Quality literature, these independent variables were thought 
to impact the effectiveness of the support function. One of the benefits of performing a study looking for as many possible influences on support effectiveness is that new independent variables as well as interrelationships between variables may surface. Service quality and user satisfaction with the information services function were used to measure the effectiveness of the support function.

\subsubsection{Independent Variables}

The independent variables examined were organizational structure, management attitudes / practices, computer support personnel, end user experience/needs, and resources. Based on the literature review, entries were added under each independent variable category possibly impacting the effectiveness of the support function. Since this was an exploratory study, the theoretical model was created as a guideline for the data collection. 


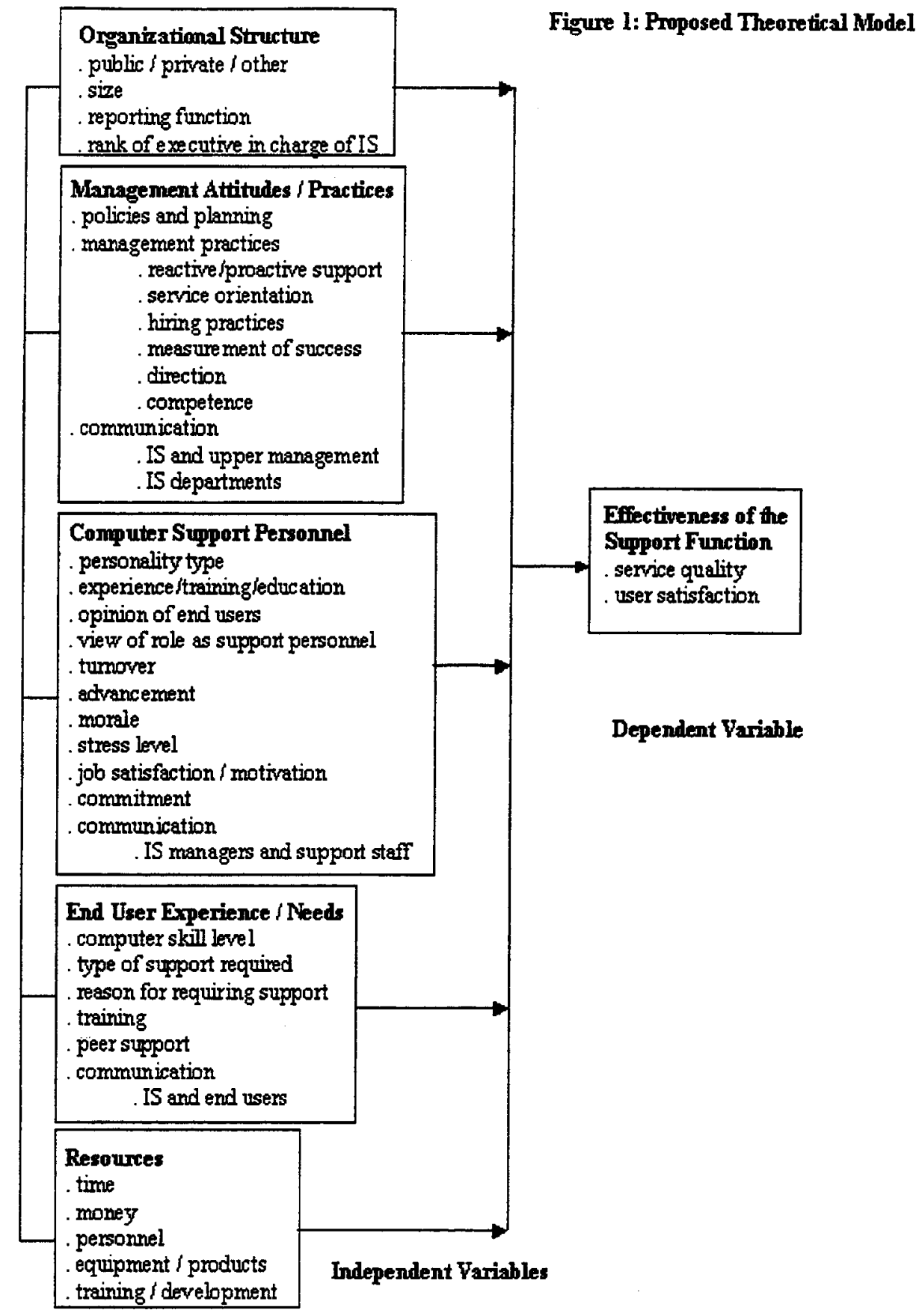




\subsubsection{Research Questions}

Influences of the five categories of independent variables on the dependent variable were examined. It was hypothesized that the independent variables impacted the effectiveness of the computer support function. The independent variables were also examined for interrelationships.

The following research questions were investigated:

Research Question \#1: How do different organizations structure their IS departments with respect to the computer support function?

Every organization may structure their computer support function differently. The support function could take the form of representatives in various IS or user departments, or could be structured as a single department. How the support function is structured must first be examined before investigating the effects this structure may have on the effectiveness of the support function.

Research Question \#2: How does the organizational structure of the IS department influence the effectiveness of the computer support function?

The organizational structure of the IS department may influence the effectiveness of the computer support function. The structure of the IS department, the reporting function, and the rank of the executive in charge of IS are areas which surfaced in the literature review which may influence the effectiveness of the computer support. Please see Table 2 for a list of references pertaining to these areas. If an organization has a centralized IS department which performs the computer support function, it may be 
difficult to support users in regional offices. The reporting function within the organization is an issue because, for example, users must know who to call to get support and support personnel must know how to escalate problems that they are unable to solve for the support to be effective. If the person in charge of the IS department is in the upper echelon of the organization, upper management in other areas may be more aware and responsive to the needs of the IS department. It may also improve the procurement of needed resources.

\begin{tabular}{|l|l|}
\hline \multicolumn{1}{|c|}{ Organizational Structure } & \multicolumn{1}{c|}{ References } \\
\hline Structure of IS department & Halloran, 1993 \\
\hline Reporting function & Patching, 1989 \\
\hline $\begin{array}{l}\text { Rank of executive in charge of } \\
\text { IS }\end{array}$ & Cheney et al., 1986 \\
\hline
\end{tabular}

Table 2: Organizational Structure References

Research Question \#3: What management attitudes / practices influence the effectiveness of the computer support function?

Management has a great deal of influence on the effectiveness of the computer support function. Management sees the creation of policies and plans that chart how support should be carried out in their organization in the present time and in the future. The field of computing sees constant changes and the ability of management to adapt their policies and plans in this changing environment may be an important factor. Various management practices surfaced in the literature review that may be influential on computer support effectiveness. Communication between management and upper 
management, computer personnel, and the end users could play a role in how effectise computer support is carried out. Please refer to Table 3 for a list of the related references.

\begin{tabular}{|l|l|l|}
\hline \multicolumn{2}{|c|}{ Management Attitudes / Practices } & \multicolumn{1}{c|}{ References } \\
\hline Policies and planning & $\begin{array}{l}\text { Cheney et al., 1986; Lederer \& } \\
\text { Mendelow, 1987; Nelson et al., 2000 }\end{array}$ \\
\hline $\begin{array}{l}\text { Management } \\
\text { practices }\end{array}$ & $\begin{array}{l}\text { Reactive / proactive } \\
\text { support }\end{array}$ & Patching, 1989 \\
\hline & Service orientation & Bowen \& Schneider, 1988 \\
\hline & Hiring practices & $\begin{array}{l}\text { Patching, 1989; White Jr. \& Christy, } \\
1987\end{array}$ \\
\hline & Measurement of success & Murray, 1996; \\
\hline & Direction & Burke, 1995 \\
\hline & Competence & Burke, 1995 \\
\hline Communication & & $\begin{array}{l}\text { Lederer \& Mendelow, 1987; Karten, } \\
1994 ; \text { Nelson and Cooprider, 1996 }\end{array}$ \\
\hline
\end{tabular}

Table 3: Management References

Research Question \#4: What computer support personnel attitudes / practices influence the effectiveness of the computer support function?

The personnel who perform the computer support for the end users have a direct influence on the support's effectiveness. What type of computer support personnel provides effective support? Related literature points to the personality, training, education, and experience of the support person. Their ability to communicate with, respect, and understand the end users' needs as well as their own role in the relationship may also be important factors. IS literature also talks about the potential impact of turnover, advancement, morale, stress level; job satisfaction, and commitment on the 
ability of personnel to deliver effective performance. Please refer to Table 4 for related references.

\begin{tabular}{|l|l|}
\hline \multicolumn{1}{|c|}{ Computer Support Personnel } & \multicolumn{1}{c|}{ References } \\
\hline Personality type, people skills & Carr, 1987; Mittal and Lassar, 1996 \\
\hline Experience / training / education & Carr, 1987; Lee, 1995; Nelson, 1991; Burke, \\
& 1995; Nelson et al., 2000; Watson et al. 1998 \\
\hline Opinion of end users & Carr, 1987; Arnoudse \& Ouellette, 1986 \\
\hline View of role as support personnel & Carr, 1987 \\
\hline $\begin{array}{l}\text { Turnover, advancement, morale, stress } \\
\text { level, job satisfaction, motivation, } \\
\text { commitment }\end{array}$ & $\begin{array}{l}\text { Hussain, 1992; Igbaria \& Greenhaus, 1992; } \\
\text { Patching, 1989; Igbaria et al., 1994; Burke, 1995; } \\
\text { Nelson et al., 2000 }\end{array}$ \\
\hline Communication & Carr, 1987 \\
\hline
\end{tabular}

Table 4: Computer Support Personnel References

Research Question \#5: How do end user experience / needs influence their perceptions of the effectiveness of the computer support function?

People have diverse personalities and skill levels. The support function must be able to satisfy the varying needs of different individuals in an effective manner. One must examine why users require support. Certain types of support calls can be avoided with proper planning. For example, a help desk may receive a lot of calls because a system was upgraded and the users were not informed on how to cope with the changes. This could be avoided with prior training and communication. The computer support function must understand the users and their needs to deliver effective support. Users could turn to peer support as an alternative to unsatisfactory support from the IS department. Please refer to Table 5 for related references. 


\begin{tabular}{|l|l|}
\hline \multicolumn{1}{|c|}{ End Users } & \multicolumn{1}{c|}{ References } \\
\hline Computer skill level & Miriani \& King, 1994 \\
\hline $\begin{array}{l}\text { Reason for requiring support; type } \\
\text { of support required }\end{array}$ & Miriani \& King, 1994; Nelson, 1991 \\
\hline Training & Cheney et al., 1986 \\
\hline Peer support & $\begin{array}{l}\text { Lee, 1986; Halloran, 1993; Karten, } \\
1994\end{array}$ \\
\hline Communication & Karten, 1994; Watson et al., 1998 \\
\hline
\end{tabular}

Table 5: End User References

Research Question \#6: What is the impact of the availability of resources on the effectiveness of the computer support function?

Resources play an integral role in the ability to deliver support. Lack of resources has been identified as a major problem with the implementation of Information Centers (White Jr. \& Christy, 1987). Time, money, personnel, equipment, and/or training constraints could stop a support function with otherwise excellent structure, management, personnel, and understanding of user needs from performing a service.

\section{THESIS METHODOLOGY}

\subsection{Overview}

This study was an exploratory, cross-sectional, field study using interviews and questionnaires to collect data. The unit of analysis was the firm.

The first stage of the study consisted of preliminary interviews with IT managers in selected companies. These interviews were done to ensure that the subject area was covered adequately based on the literature review and to gain a manager's perspective on 
the computer support function and its effectiveness. The management interviews also sought to validate management's view of the importance of computer support effectiveness. Managers were questioned about the structure of the computer support function in their organizations, the types of computer support personnel and end users, and the sorts of problems they have encountered in the past and are still currently facing. Areas of interest that surfaced during these interviews, not accounted for in the original interview protocol, were added.

The main study examined the computer support function within twelve organizations looking at the computer support function from different perspectives. Interviews were done with management and computer support personnel to find out their opinions on the various issues involving computer support. End user surveys were conducted to evaluate the effectiveness of the computer support provided.

\subsection{Sampling Design}

The twelve organizations participating in the main study were chosen by a convenience sample focusing on medium-to-large size organizations. Approximately 65 organizations were approached for participation in the study. Each organization had at least one department specializing in computer support. The organizations were located in the Ottawa and Toronto areas for interviewer convenience. This study was primarily interested in the support of business systems (i.e. financial systems, word processing, etc.) and selected organizations of this nature. People who use computers for technical 
reasons (i.e. high tech companies) may have different needs than business computer users. The choice of selecting business users was to try and keep the general reasons for using computers relatively constant. This does limit the generalizability of the study to like organizations.

Public, private, and other (e.g., crown corporations) organizations were selected to investigate if differences exist between the nature of the support function in each. This study was interested in comparing companies who perform support with varying degrees of effectiveness. Questions were posed to potential study participants concerning how well they felt support was carried out in their organization to try and gauge their potential level of support effectiveness.

Attempts were made to choose organizations based on the following criteria:

\begin{tabular}{|l|l|}
\hline \multicolumn{1}{|c|}{ Similarities } & \multicolumn{1}{c|}{ Differences } \\
\hline Size of organization & Public / private / other \\
\hline Location of organization & Effective / not effective \\
\hline Business users & \\
\hline
\end{tabular}

In the main study, surveys were distributed by managers with the request of random user selection and were mailed back directly to the researcher. Multiple managers and support personnel were interviewed in each organization (in most cases, 3 managers and 4 support personnel) to try and remove some of the bias incurred by allowing management to select the interviewees. 


\subsection{Procedures}

\subsubsection{Pretest}

The first stage of the data collection process consisted of preliminary interviews with selected managers; one from the private sector and one from the public sector. The literature review was done to determine possible influences on computer support effectiveness. Preliminary interviews were done to investigate other possible factors that were not present in the literature. The preliminary interviews also sought to validate management's view of the importance of computer support effectiveness.

The interviews showed that the managers all felt that computer support is an important part of an organization and that the computer support function encounters many unique problems (i.e. restrictive policies, lack of resources, computer support personnel who may lack communication and people skills). Questions regarding methods for monitoring problems, outsourcing, and proactive versus reactive support were added to the interview protocol as these topics surfaced in the interviews.

It was felt that although management interviews provided a lot of good information, they should not be used as the sole source of data for the study. It was difficult to determine if what the manager said (e.g. what is the focus or the main problems encountered by the support function) is the same as another manager or a support person's point of view. The management interviews also do not provide any outcome information (i.e. how satisfied are the users with the support given?). Multiple 
management interviews and computer support personnel interviews as well as an end user survey were chosen for the main study to cover the subject area from different perspectives.

\subsubsection{Main Study}

The main study consisted of mini-case studies of twelve organizations. Potential organizations were contacted via mail with a description of the study followed by telephone calls to answer any questions and recruit participants. Twelve organizations agreed to participate.

Management and support personnel interviews and an end user survey were conducted in each participating organization.

The interviews with management had the same format as the preliminary interviews with the addition of questions determined by the pretest.

The interviews with computer support personnel were done to examine their views on various items that might impact the effectiveness of computer support. Interviews were chosen to probe the support personnel for details so that as well as finding out, for example, there is a communication problem between IS and upper manager, it is important to collect some opinions as to what is the problem, why does it exist, and how could it be improved.

The final part of the data collection process was to survey end users on the effectiveness of the computer support function. Questionnaires were chosen over 
interviews for the end users in order to survey a greater number of end-users to attempt to eliminate individual biases.

The confidentiality of respondents was ensured and no financial benefits were provided for participation. The organizations participating in the study received an evaluation of how end users rated the effectiveness of their support as well as a comparison of their computer support setup to other anonymous organizations.

\subsection{Instruments}

Please refer to Appendices 1 and 2 for a copy of the management and support personnel interview questions.

End-users were given the SERVQUAL instrument as a measure of service quality. A single question pertaining to the computer support function's overall quality was also given. Galletta and Lederer's (1989) four summary USISF items were administered to the end-users to obtain a measurement of user satisfaction with the information services function. Munro et al.'s (1995) end user sophistication items were also administered. Additional questions were asked concerning general demographics, the position of the individual, and who and how often the user contacts for support. Please refer to Appendix 3 for a copy of the end user survey. 


\section{DATA ANALYSIS AND FINDINGS}

\subsection{Overview}

\subsubsection{Description of Research}

In 1997, twelve organizations participated in this study examining the effectiveness of the computer support function in organizations. The study examined the management problem of how organizations can provide effective computer support. Please refer to section 5.1.2 for a discussion of the data age.

The study was divided into two parts. The first part looked at the effectiveness of the participating organizations in providing computer support. The end users rated the effectiveness of the computer support function in their organization. The effectiveness ratings in one organization were compared to the overall ratings for users in all participating organizations.

The second part of the study investigated the following: What factors influenced the quality of service provided by the support function? What distinguished an organization where the users are satisfied with their current level of support from one where the users are dissatisfied?

In each of the participating organizations, data was collected from three different sources. Interviews were used to collect qualitative data from IS managers and support personnel on the above research questions. Interviews were conducted with a total of 35 
IS managers and 42 support personnel. End user surveys were used to collect data on the users' perceptions of the quality of service provided by the support function in their organization. The surveys also collected data on the users' levels of satisfaction with the information systems function as well as on their level of computer expertise. Fifty surveys were distributed to users in each organization for a total of 600 surveys with an overall response rate of $45.5 \%$.

\subsubsection{Description of Participating Organizations}

All of the participating organizations had at least one department specializing in computer support of business systems (e.g., financial systems, word processing, etc.). The organizations were located in the Ottawa or Toronto area.

Both public and private organizations were selected to investigate if differences existed between the nature of the support function in each. The companies were divided into one of the following categories: private, government, or other (e.g., crown corporations). Three private, five government, and four other organizations participated in the study.

\subsubsection{Analysis Methodology Overview}

The data collection phase produced both qualitative and quantitative data. The statistical analysis was limited due to the small sample size for the qualitative data and the unit of analysis of the firm. Instead of attempting to generalize the results to the general population as in statistical analysis, the object of this study was to explore the 
subject area and develop a more precise theoretical model with specific hypotheses to be tested in future research using the case study approach. Using multiple cases allowed the possible generalization to theoretical propositions not to populations (Yin, 1989). In other words, replicating a proposition was analogous to replicating an experiment.

Each of the independent variables and their subsets were linked to management and support personnel interview questions. Please refer to Appendix 5 for a list of the variables and their associated questions. These questions probed the subjects for information on the subject area relating to the independent variables. All interviews were transcribed and coded according to each interview question. The interview questions were then rolled up to the appropriate independent variable and summarized by organization. The summarizations included categorized answers as well as notes concerning agreement or disagreement among participants from a single organization. A list of relevant quotes was also maintained for use in illustrating points in the analysis portion of the study.

The results of the end user questionnaires were calculated to give an estimate of the level of computer support effectives (service quality, user satisfaction) each organization provided. The instruments used to measure service quality, user satisfaction, and end user sophistication were evaluated with respect to validity, reliability, and generalizability.

Each organization was assigned a computer support effectiveness rating (see section 4.3). The organization size (large/medium/small) and company type 
(private/government/other) were taken into account during the comparisons to determine if there was an influencing factor.

Computer support effectiveness (service quality, user satisfaction) was examined in each organization and between organizations. For independent variables where quantitative data was available (e.g., information technology familiarity), analysis ${ }^{3}$ examined if significant differences exist between the responses given by end-users. For independent variables where qualitative data was available, the categorized answers by organization were used for analysis using the following approach.

The categorized answers relating to a specific independent variable were examined for mutual exclusivity (i.e., did each organization have one answer to a particular question). For example, the computer support staff turnover variable represented the amount of turnover in an organization. The set of answers could be high, medium, low, none, or mixed opinion. This would be a mutually exclusive set of answers with each organization having a single answer. Other questions may produce nonmutually exclusive answers where one organization may have none, one, or several answers. An example of this would be what type of skills do managers look for when hiring? In this case, there would be multiple answers by organization.

${ }^{3}$ Using a variety of statistical methodologies, such as analysis of variance, and bi-variate correlations (Pearson correlation coefficient, two-tailed test of significance) 
The answers were tabulated (noting if mutually exclusive or not) by number of reporting organizations, computer support effectiveness, organization size, and company type and examined for trends. For example, did the highly effective organizations favour a particular answer? Where trends were apparent, hypotheses were created based on the trend.

The independent variable analysis sections contain several tables such as the following.

\begin{tabular}{|c|l|c|l|c|}
\hline $\begin{array}{c}\text { Independent } \\
\text { Variable }\end{array}$ & $\begin{array}{c}\text { \# of } \\
\text { Organizations }\end{array}$ & Size & Type & Effectiveness \\
\hline Answer A & 9 & $\begin{array}{c}4 \text { large } \\
3 \text { medium } \\
\end{array}$ & $\begin{array}{c}3 \text { government } \\
3 \text { other } \\
3 \text { small }\end{array}$ & $\begin{array}{c}3 \text { high } \\
3 \text { medium } \\
3 \text { low }\end{array}$ \\
\hline Answer B & 3 & $\begin{array}{c}1 \text { large } \\
1 \text { medium } \\
\end{array}$ & $\begin{array}{c}\text { 2 government } \\
1 \text { other }\end{array}$ & $\begin{array}{c}1 \text { high } \\
1 \text { medium } \\
1 \text { small }\end{array}$ \\
& & & \\
\hline
\end{tabular}

The categorized answers to the independent variable being examined are displayed in the leftmost column. In the "\# of Organizations" box, a footnote denotes whether the answers are mutually exclusive or not. If the table was mutually exclusive, the above example would represent that 9 organizations replied with Answer A and 3 with Answer B. The "\# of Organizations" column should add up to twelve if all organizations answered the question. If the table was not mutually exclusive, the above example would represent that 9 organizations provided Answer A and 3 organizations

\footnotetext{
${ }^{4}$ Mutually exclusive.
} 
provided Answer B. Two of the organizations that provided Answer A could also have provided Answer B. In this case, the "\# of Organizations" column would not add up to twelve. These tables also provide the breakdown of how many organizations, for each answer, were large/medium/small, government/private/other, and high/medium/low effectiveness.

In some instances, interview participants brought up interesting points relating to computer support effectiveness that were not addressed in all the interviews. This may have occurred in some of the more open-ended questions. If the point seemed credible (e.g., if the comment fit with either past research, other related questions, or had vocal support from more than one participant in a single organization) and was deemed to add a new point for investigation, a potential hypothesis was created so that the point was not lost and could be taken into account for testing in future research. The inclusivity of potential hypotheses was valuable since the goal of the study was to set the groundwork for future research.

Along with the determination of hypotheses for the computer support effectiveness model, comments or suggestions related to possible future research were also noted. 


\subsection{Validity and Reliability}

\subsubsection{SERVQUAL Instrument}

The SERVQUAL instrument as per Pitt et al. (1995) was used as the measure of service quality. A single question pertaining to the computer support function's overall quality was also used. SERVQUAL was calculated using the Perceptions Only model or using the Gap model. The reliability, validity, and generalizability of the SERVQUAL instrument were examined.

\subsubsection{Reliability}

Reliability was the degree to which a test consistently measured whatever it measured. The reliability of the SERVQUAL instrument was assessed in past studies (Pitt et al., 1995, Van Dyke et al. 1997, Pitt et al. 1997, Kettinger and Lee 1997, Watson et al. 1998) in the IS context and was assessed in the current study.

The reliability of each of SERVQUAL's dimensions was examined for both the Perceptions Only instrument as well as for the Gap instrument. Cronbach's alpha was used to determine the reliabilities. Each scale was examined to see if any items should be dropped; no such items were found. Please refer to Appendix 6 for details on the evaluation and results.

The reliabilities for the Perceptions only instrument ranged from 0.74 to 0.92 with the reliability of the linear combination being 0.94 . The Tangibles scale had the lowest reliability at 0.74 with the other scales ranging from 0.89 to 0.92 . 
The reliabilities for the dimensions of the Gap instrument ranged from 0.67 to 0.92 with the reliability of the linear combination being 0.92 . The Tangibles scale had the lowest reliability at 0.67 with the other scales ranging from 0.87 to 0.92 .

The Perceptions only model was consistently more reliable than the Gap model.

Pitt et al. (1995) used the IS version of the SERVQUAL Gap instrument in three different firms: a financial institution, a consulting firm, and an information service. The financial firm sample was similar to this study's sample (i.e. business organization that uses computers as a tool). The results from this study displayed higher reliabilities on each scale than the Pitt financial sample. Please refer to Appendix 6 for details.

\subsubsection{Validity}

Validity examined the extent to which differences found with a measuring tool reflected true differences among respondents being tested. Content, convergent, and discriminant validity were examined.

Content validity was the degree to which a test measured an intended content area. A literature search was done and expert management opinion solicited to account for content validity.

Convergent validity was the degree of association between two different measurement scales that purported to measure the same concept. This was assessed by correlating the overall service quality index with a single question on the computer support function's overall quality. 
The overall service quality rating, computed from the five dimensions for both the perceptions only and gap model, was compared to the single response on the IS department's overall quality. There was a high correlation ${ }^{5}$ between each of the models and the single question indicating convergent validity. The Perceptions Only model had a 0.90 correlation $(p<0.01)$ and the Gap model had a 0.76 correlation $(p<0.01)$.

Discriminant validity was evident if items underlying each dimension loaded as different factors. (Pitt et al. 1995).

Principal components factor analysis with a varimax rotation was done for the perceptions only items as well as for the gap items. Please refer to Appendix 6 for details. A two factor model was found in both the Perceptions Only and Gap models. In the Perceptions Only model, the reliability items with the exception of one loaded together on the first factor with the exception split evenly between the two factors. The empathy, responsiveness, and assurance items all loaded together on the first factor. The tangibles items all loaded together on the second factor. In the Gap model, the reliability, empathy, responsiveness, and assurance items all loaded together on the first factor. The tangibles items, with the exception of one question that was split between the two factors, all loaded together on the second factor.

\footnotetext{
${ }^{5}$ Bivariate correlation, Pearson correlation co-efficient, two-tailed test of significance
} 
Since the reliability, assurance, empathy, and responsiveness items loaded together in one factor and not separate factors, there was a problem with the discriminant validity. The tangibles items loaded on their own factor.

\subsubsection{Perception Only Model versus Gap Model}

The reliability of the SERVQUAL dimensions as well as the convergent validity were higher for the perceptions-only model then the gap model. This corresponded with the service quality literature and provided a direct comparison among organizations. The perceptions-only measure was used as the Service Quality measure for the remainder of the analysis.

Due to the lack of discriminant validity for the five Service Quality factors and the appearance of a two-factor model, two Service Quality factors were used for the analysis: service quality factor \#1 (loaded with the assurance, reliability, responsiveness, and assurance items) and tangibles factor \#2. The new service quality factor \#1 had a reliability of $0.97^{6}$ and exhibited convergent validity with a 0.91 correlation $(p<0.01)$ to the single service quality question.

\footnotetext{
${ }^{6}$ No positive impact to reliability if drop any items
} 


\subsubsection{Reliability of User Information Satisfaction Instrument}

Galletta and Lederer's (1989) four summary USISF items were administered to the end-users obtaining a measurement of user satisfaction with the information services function.

S1: Satisfaction with Involvement and Participation

S2: Satisfaction with Support and Services

S3: Satisfaction with Product

S4: Overall Satisfaction with IS Environment

The reliability ${ }^{7}$ was 0.89 . No positive impacts on reliability were found when removing individual items from the scale.

\subsubsection{Reliability of End User Sophistication Instrument}

Munro et al.'s (1995) end user sophistication items were administered in the survey. The breadth, depth, and finesse values were examined with their reliabilities ${ }^{8}$ ranging from 0.92 and 0.96 . No positive impacts on reliability were found when removing individual items from the scales.

\footnotetext{
${ }^{7}$ Cronbach's alpha

${ }^{8}$ Cronbach's alpha
} 


\subsection{Effectiveness Indicators of Organizations}

The proposed theoretical model used both service quality and user satisfaction as the indicators of the organization's effectiveness in providing computer support.

The IS department provided services as well as products. The quality of the service provided by the IS department was an important factor in determining its effectiveness. Users in each participating organization ranked the overall service quality of their organization on a scale of 1 to 7.1 represented Poor and 7 represented Excellent. A ranking of 4 is considered Neutral. The service quality represented the quality of computer support provided by the IS department as perceived by the users in the organization.

Users also rated their satisfaction on a scale of 1 to 7 , where 1 represented "Not Satisfied" and 7 represented "Satisfied", on the following items:

- Their satisfaction with their involvement and participation in the operations and ongoing development of information systems

- Their satisfaction with the support and services of the Information Systems department

- Their satisfaction with the information / data produced by the information systems

- Their overall satisfaction with the entire information systems environment 
Both the service quality and user satisfaction scales ranged from 1 to 7 (Poor $\Rightarrow$ Excellent, Not Satisfied $\Rightarrow$ Satisfied).

An overall effectiveness rating was obtained by taking the average of service quality and user satisfaction values. The following table displays the mean, standard deviation, minimum, and maximum values by organization for each of the effectiveness variables: service quality (overall and factors), user satisfaction, and overall effectiveness. As previously mentioned, these variables were measured on a scale 1 to 7 .

\begin{tabular}{|c|c|c|c|c|c|c|}
\hline \multicolumn{2}{|c|}{ ORG\# } & \multirow{2}{*}{$\begin{array}{r}\begin{array}{r}\text { Overall } \\
\text { Service } \\
\text { Quality }\end{array} \\
4.9675\end{array}$} & \multirow{2}{*}{$\begin{array}{r}\begin{array}{c}\text { Service } \\
\text { Quality } \\
\text { Factor \#1 }\end{array} \\
4.9214\end{array}$} & \multirow{2}{*}{$\begin{array}{r}\begin{array}{l}\text { Tangibles } \\
\text { Factor \#2 }\end{array} \\
5.1518\end{array}$} & \multirow{2}{*}{$\begin{array}{r}\begin{array}{c}\text { User } \\
\text { Satisfaction }\end{array} \\
4.9815\end{array}$} & \multirow{2}{*}{$\begin{array}{c}\begin{array}{c}\text { Overall } \\
\text { Effectiveness }\end{array} \\
4.9188\end{array}$} \\
\hline \multirow{4}{*}{1} & Mean & & & & & \\
\hline & $\begin{array}{l}\text { Std. } \\
\text { Deviation }\end{array}$ & 1.2323 & 1.3862 & .8775 & 1.3953 & 1.2835 \\
\hline & Minimum & 1.59 & 1.36 & 2.50 & 1.00 & 1.30 \\
\hline & Maximum & 6.69 & 6.74 & 6.50 & 7.00 & 6.60 \\
\hline \multirow{4}{*}{2} & Mean & 5.0338 & 5.1662 & 4.7870 & 4.8056 & 4.8967 \\
\hline & $\begin{array}{l}\text { Std. } \\
\text { Deviation }\end{array}$ & .7998 & .8990 & .8624 & .9414 & .8139 \\
\hline & Minimum & 3.75 & 3.63 & 3.25 & 2.25 & 3.00 \\
\hline & Maximum & 6.90 & 7.00 & 6.75 & 6.75 & 6.83 \\
\hline \multirow{4}{*}{3} & Mean & 5.2168 & 5.2306 & 5.2031 & 5.4194 & 5.3122 \\
\hline & $\begin{array}{l}\text { Std. } \\
\text { Deviation }\end{array}$ & 1.1466 & 1.2127 & 1.1490 & 1.1169 & 1.0735 \\
\hline & Minimum & 2.59 & 2.24 & 3.25 & 2.25 & 2.42 \\
\hline & Maximum & 7.00 & 7.00 & 7.00 & 7.00 & 7.00 \\
\hline 4 & Mean & 4.5471 & 4.6629 & 4.4435 & 4.4844 & 4.4521 \\
\hline
\end{tabular}




\begin{tabular}{|c|c|c|c|c|c|c|}
\hline \multicolumn{2}{|c|}{ ORG\# } & \multirow{2}{*}{$\begin{array}{r}\begin{array}{r}\text { Overall } \\
\text { Service } \\
\text { Quality }\end{array} \\
.7048\end{array}$} & \multirow{2}{*}{$\begin{array}{r}\begin{array}{c}\text { Service } \\
\text { Quality } \\
\text { Factor \#1 }\end{array} \\
.8337\end{array}$} & \multirow{2}{*}{$\begin{array}{r}\begin{array}{r}\text { Tangibles } \\
\text { Factor \#2 }\end{array} \\
1.0302\end{array}$} & \multirow{2}{*}{$\begin{array}{c}\begin{array}{c}\text { User } \\
\text { Satisfaction }\end{array} \\
1.1179\end{array}$} & \multirow{2}{*}{$\begin{array}{c}\begin{array}{c}\text { Overall } \\
\text { Effectiveness }\end{array} \\
.7927\end{array}$} \\
\hline & $\begin{array}{l}\text { Std. } \\
\text { Deviation }\end{array}$ & & & & & \\
\hline & Minimum & 3.19 & 2.99 & 1.75 & 1.75 & 2.85 \\
\hline & Maximum & 5.64 & 6.45 & 7.00 & 7.00 & 5.73 \\
\hline \multirow{4}{*}{5} & Mean & 4.9782 & 4.8000 & 4.9150 & 4.5000 & 4.8091 \\
\hline & $\begin{array}{l}\text { Std. } \\
\text { Deviation }\end{array}$ & 1.3366 & 1.5546 & 1.2262 & 1.5338 & 1.3810 \\
\hline & Minimum & 2.00 & 1.24 & 2.00 & 1.00 & 1.75 \\
\hline & Maximum & 6.88 & 6.85 & 7.00 & 7.00 & 6.94 \\
\hline \multirow{4}{*}{6} & Mean & 4.2048 & 4.2395 & 4.3233 & 4.3516 & 4.2185 \\
\hline & $\begin{array}{l}\text { Std. } \\
\text { Deviation }\end{array}$ & 1.1313 & 1.2277 & .9517 & 1.3632 & 1.1465 \\
\hline & Minimum & 1.70 & 1.50 & 2.50 & 1.50 & 1.60 \\
\hline & Maximum & 6.90 & 7.00 & 6.75 & 7.00 & 6.77 \\
\hline \multirow{4}{*}{7} & Mean & 5.4967 & 5.6000 & 5.0577 & 4.8077 & 5.1858 \\
\hline & $\begin{array}{l}\text { Std. } \\
\text { Deviation }\end{array}$ & 1.0319 & 1.0948 & .8965 & 1.0857 & 1.0557 \\
\hline & Minimum & 3.82 & 3.84 & 3.75 & 2.75 & 3.29 \\
\hline & Maximum & 6.85 & 6.94 & 6.50 & 6.50 & 6.68 \\
\hline \multirow{4}{*}{8} & Mean & 4.8714 & 4.9395 & 4.9565 & 4.6759 & 4.7311 \\
\hline & $\begin{array}{l}\text { Std. } \\
\text { Deviation } \\
\end{array}$ & 1.0301 & 1.1487 & .9876 & 1.1198 & 1.0280 \\
\hline & Minimum & 3.26 & 2.74 & 2.75 & 2.00 & 2.93 \\
\hline & Maximum & 7.00 & 7.00 & 7.00 & 6.50 & 6.63 \\
\hline \multirow[t]{3}{*}{9} & Mean & 5.1687 & 5.2353 & 5.0938 & 5.4559 & 5.3109 \\
\hline & $\begin{array}{l}\text { Std. } \\
\text { Deviation }\end{array}$ & 1.0143 & 1.0460 & 1.0201 & .8981 & .8750 \\
\hline & Minimum & 2.95 & 3.00 & 2.75 & 4.00 & 3.85 \\
\hline
\end{tabular}




\begin{tabular}{|c|c|c|c|c|c|c|}
\hline \multicolumn{2}{|l|}{ ORG\# } & \multirow{2}{*}{$\begin{array}{r}\begin{array}{r}\text { Overall } \\
\text { Service } \\
\text { Quality }\end{array} \\
6.86\end{array}$} & \multirow{2}{*}{$\begin{array}{r}\begin{array}{c}\text { Service } \\
\text { Quality } \\
\text { Factor \#1 }\end{array} \\
6.95\end{array}$} & \multirow{2}{*}{$\begin{array}{r}\begin{array}{l}\text { Tangibles } \\
\text { Factor \#2 }\end{array} \\
6.50\end{array}$} & \multirow{2}{*}{$\begin{array}{r}\begin{array}{c}\text { User } \\
\text { Satisfaction }\end{array} \\
7.00\end{array}$} & \multirow{2}{*}{$\begin{array}{c}\begin{array}{c}\text { Overall } \\
\text { Effectiveness }\end{array} \\
6.93 \\
\end{array}$} \\
\hline & Maximum & & & & & \\
\hline \multirow{4}{*}{10} & Mean & 4.5300 & 4.4839 & 4.7143 & 4.1786 & 4.3543 \\
\hline & $\begin{array}{l}\text { Std. } \\
\text { Deviation }\end{array}$ & 1.4664 & 1.6428 & 1.0938 & 1.6375 & 1.5063 \\
\hline & Minimum & 2.45 & 2.06 & 3.50 & 1.75 & 2.62 \\
\hline & Maximum & 6.62 & 6.71 & 6.25 & 6.25 & 6.44 \\
\hline \multirow{4}{*}{11} & Mean & 5.6520 & 5.7400 & 5.0833 & 5.7917 & 5.8010 \\
\hline & $\begin{array}{l}\text { Std. } \\
\text { Deviation }\end{array}$ & .5093 & .6699 & .8756 & .9410 & .7037 \\
\hline & Minimum & 5.27 & 5.24 & 4.00 & 4.75 & 5.02 \\
\hline & Maximum & 6.46 & 6.89 & 6.25 & 7.00 & 6.73 \\
\hline \multirow{4}{*}{12} & Mean & 4.4500 & 4.4219 & 4.8281 & 4.5278 & 4.4654 \\
\hline & $\begin{array}{l}\text { Std. } \\
\text { Deviation }\end{array}$ & .8021 & .8640 & .6995 & 1.3309 & .8802 \\
\hline & Minimum & 3.24 & 3.11 & 3.75 & 1.50 & 2.50 \\
\hline & Maximum & 5.99 & 6.05 & 6.25 & 7.00 & 5.62 \\
\hline \multirow{4}{*}{ Total } & Mean & 4.8714 & 4.8864 & 4.8538 & 4.7838 & 4.8153 \\
\hline & $\begin{array}{l}\text { Std. } \\
\text { Deviation }\end{array}$ & 1.0996 & 1.2149 & 1.0188 & 1.2682 & 1.1158 \\
\hline & Minimum & 1.59 & 1.24 & 1.75 & 1.00 & 1.30 \\
\hline & Maximum & 7.00 & 7.00 & 7.00 & 7.00 & 7.00 \\
\hline
\end{tabular}

Table 6: Effectiveness Ratings by Organization

Using analysis of variance to compare the mean scores across organizations, a significant statistical difference was found for each of the effectiveness measures and factors between organizations. The following table displays the results, including 
significance levels, from the ANOVA calculations examining the differences between organizations with respect to the effectiveness variables.

\begin{tabular}{|c|c|c|c|c|c|c|}
\hline \multicolumn{2}{|l|}{ ANOVA Table } & $\begin{array}{l}\text { Sum of } \\
\text { Squares }\end{array}$ & df & $\begin{array}{l}\text { Mean } \\
\text { Square }\end{array}$ & $\mathbf{F}$ & Sig. \\
\hline \multirow{3}{*}{$\begin{array}{l}\text { Overall Service } \\
\text { Quality } \\
\text { * ORG\# }\end{array}$} & $\begin{array}{l}\text { Between Groups } \\
\text { (Combined) }\end{array}$ & 32.945 & 11 & 2.995 & 2.665 & .003 \\
\hline & Within Groups & 259.650 & 231 & 1.124 & & \\
\hline & Total & 292.595 & 242 & & & \\
\hline \multirow{3}{*}{$\begin{array}{l}\text { Service Quality } \\
\text { Factor \#1 } \\
\text { * ORG\# }\end{array}$} & $\begin{array}{l}\text { Between Groups } \\
\text { (Combined) }\end{array}$ & 36.939 & 11 & 3.358 & 2.413 & .007 \\
\hline & Within Groups & 340.905 & 245 & 1.391 & & \\
\hline & Total & 377.844 & 256 & & & \\
\hline \multirow{3}{*}{$\begin{array}{l}\text { Tangibles Factor \# } 2 \\
\text { * ORG\# }\end{array}$} & $\begin{array}{l}\text { Between Groups } \\
\text { (Combined) }\end{array}$ & 22.152 & 11 & 2.014 & 2.027 & .027 \\
\hline & Within Groups & 239.406 & 241 & .993 & & \\
\hline & Total & 261.558 & 252 & & & \\
\hline \multirow{3}{*}{$\begin{array}{l}\text { User Satisfaction } \\
\text { * ORG\# }\end{array}$} & $\begin{array}{l}\text { Between Groups } \\
\text { (Combined) }\end{array}$ & 42.612 & 11 & 3.874 & 2.565 & .004 \\
\hline & Within Groups & 383.583 & 254 & 1.510 & & \\
\hline & Total & 426.195 & 265 & & & \\
\hline \multirow{3}{*}{$\begin{array}{l}\text { Overall } \\
\text { Effectiveness } \\
\text { * ORG\# }\end{array}$} & $\begin{array}{l}\text { Between Groups } \\
\text { (Combined) }\end{array}$ & 35.319 & 11 & 3.211 & 2.793 & .002 \\
\hline & Within Groups & 260.995 & 227 & 1.150 & & \\
\hline & Total & 296.314 & 238 & & & \\
\hline
\end{tabular}

Table 7: Statistical Significance between Organizations

The service quality and user satisfaction differences were expected as each organization differed in aspects of how they delivered computer support. Although all organizations had an average effectiveness rating greater than the Neutral (4) rating, some 
had Neutral ratings while others had Very Good ratings with others somewhere in between. Due to the significant differences between organizations based on the study's indicator of effectiveness (Service Quality + User Satisfaction) and the expressed need by managers in several organizations to improve their computer support service, there was a basis to perform comparison on computer support practices between organizations based on computer support effectiveness.

Two methods were examined in assigning the organizations to computer support effectiveness categories for comparison purposes. The first was to compare organizations with an average effectiveness rating greater than or equal to the overall mean to organizations with an average effectiveness rating less than the mean. The second was to divide the organizations into three effectiveness tiers representing low, medium, and high effectiveness. While Low does not represent a Poor effectiveness rating, it represents the lowest ratings based on the organizations studied. The tiers were determined by taking the difference between the highest mean per organization (5.8) and the lowest mean (4.2) and creating three equal ranges: $4.2-4.7,4.7-.5 .2$, and 5.2-5.8.

The results per organization including categorization based on above/below overall mean and tier are displayed in the following table and Figure 2. 


\begin{tabular}{|c|c|c|c|c|c|c|}
\hline Org \# & $\begin{array}{c}\text { Comparison } \\
\text { to Overall } \\
\text { Mean }\end{array}$ & Tier & Mean & $\begin{array}{c}\text { Standard } \\
\text { Deviation }\end{array}$ & Min & Max \\
\hline 1 & $>=$ & Medium & 4.9 & 1.3 & 1.3 & 6.6 \\
\hline 2 & $>=$ & Medium & 4.9 & 0.8 & 3 & 6.8 \\
\hline 3 & $>=$ & High & 5.3 & 1.1 & 2.4 & 7 \\
\hline 4 & $<$ & Low & 4.5 & 0.8 & 2.8 & 5.7 \\
\hline 5 & $>=$ & Medium & 4.8 & 1.4 & 1.7 & 6.9 \\
\hline 6 & $<$ & Low & 4.2 & 1.1 & 1.6 & 6.8 \\
\hline 7 & $>=$ & High & 5.2 & 1.1 & 3.3 & 6.7 \\
\hline 8 & $<$ & Medium & 4.7 & 1 & 2.9 & 6.6 \\
\hline 9 & $>=$ & High & 5.3 & 0.9 & 3.8 & 6.9 \\
\hline 10 & $<$ & Low & 4.4 & 1.5 & 2.6 & 6.4 \\
\hline 11 & $>=$ & High & 5.8 & 0.7 & 5 & 6.7 \\
\hline 12 & $<$ & Low & 4.5 & 0.9 & 2.5 & 5.6 \\
\hline Overall & & & 4.8 & 1.1 & 1.3 & 7 \\
\hline
\end{tabular}

Table 8: Effectiveness Ratings by Organization 


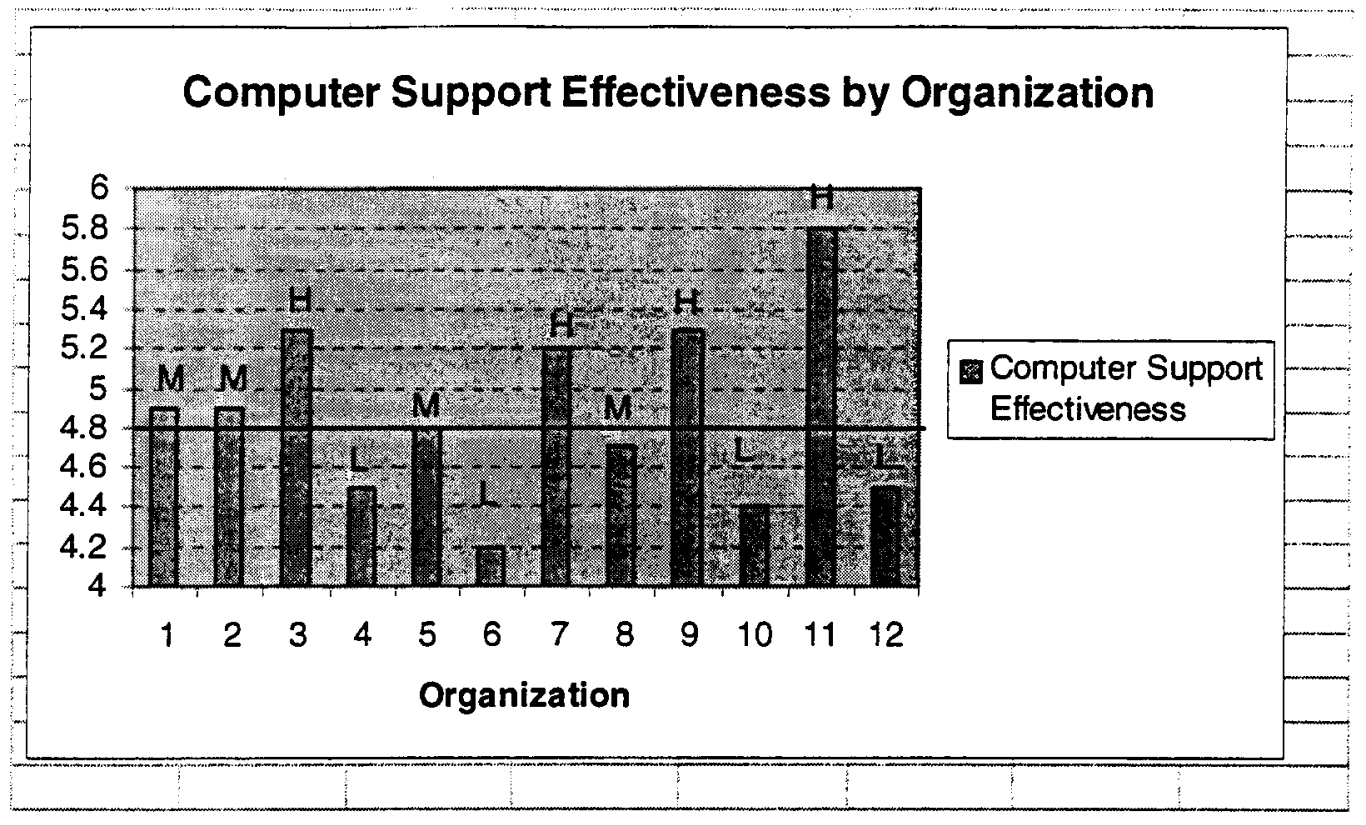

Figure 2: Organization Effectiveness Classification

Seven organizations had effectiveness values greater than or equal to the overall mean. There were four organizations that fit in each tier (low, medium, and high). Since there were several organizations with effectiveness ratings close to the mean, it was felt that the effectiveness tier approach would be more useful in looking for possible trends in computer support variables related to effectiveness.

The organizations were classified for additional comparisons into three service quality levels as shown in the following table and Figure 2 above. 


\begin{tabular}{|l|l|l|}
\hline Effectiveness Classification & \multicolumn{1}{|c|}{$\begin{array}{c}\text { \# of } \\
\text { Organizations }\end{array}$} & $\begin{array}{c}\text { Organization } \\
\text { (Org \#) }\end{array}$ \\
\hline High $(>=5.2)$ & 4 & $4,6,10,12$ \\
\hline Medium $(>=4.7,<5.2)$ & 4 & $1,2,5,8$ \\
\hline Low $(<4.7)$ & 4 & $3,7,9,11$ \\
\hline
\end{tabular}

Table 9: Organization Effectiveness Classification

The user's expectations for service quality were examined with respect to the organization. No significant differences were found for expectations of service quality, its factors, user satisfaction, or effectiveness between organizations. Although no statistical differences were found between organizations, during the interview process several support personnel and managers brought up issues with their ability to properly manager user expectations (see sections 4.5.1.2.7 and 4.7.1.6). Van Dyke et al. (1997) stated that "IS professionals have been known to raise expectations to an unrealistically high level in order to gain user commitment to new systems and technologies. This can make it much more difficult to deliver systems and services that will be perceived as successful." They recommended separating out "will" and "should" expectations to compare against the direct response or perceptions-only method of scoring. To improve perceived service quality, you can improve actual performance or manage expectations

\footnotetext{
${ }^{9}$ Mutually exclusive
} 
specifically by reducing "should" expectations and/or increasing "will" expectations. For example, instead of a user expecting that support should be provided in a timely manner, the better situation would be for the user to expect that support will be provided according the agreed-upon service level agreements. Alternate ways of measuring and evaluating expectations of Information Systems service quality should be investigated further in future computer support research.

\subsubsection{Effectiveness by Company Type}

The organizations each belonged to a company type: public, government, or other (e.g., crown corporations). Of the twelve organizations participating in the study, three were private, five are government, and four are other.

Average computer support effectiveness ratings by company type are displayed in Table 10. These scales range from a value of 1 to 7 as described in section 4.3.where 1 is Poor and 7 is Excellent.

\begin{tabular}{|l|l|l|l|l|l|}
\cline { 2 - 5 } & \multicolumn{3}{c|}{ Service Quality } & \multicolumn{1}{c|}{$\begin{array}{c}\text { User } \\
\text { Satisfaction }\end{array}$} & $\begin{array}{c}\text { Overall } \\
\text { Effectiveness }\end{array}$ \\
\cline { 2 - 6 } & $\begin{array}{c}\text { Overall } \\
\text { Service } \\
\text { Quality }\end{array}$ & $\begin{array}{c}\text { Service } \\
\text { Quality } \\
\text { Factor \#1 }\end{array}$ & $\begin{array}{c}\text { Tangibles } \\
\text { Factor \#2 }\end{array}$ & & \\
\hline Private & 4.7 & 4.7 & 4.9 & 4.7 & 4.7 \\
\hline Government & 4.7 & 4.7 & 4.7 & 4.6 & 4.6 \\
\hline Other & 5.1 & 5.2 & 5.1 & 5.0 & 5.1 \\
\hline
\end{tabular}

Table 10: Effectiveness Rating by Company Type 
Using analysis of variance, a significant statistical difference $(\mathrm{p}<0.05)$ was found for each of the effectiveness measures and factors between the different types of companies. The results are displayed in the following table. All of the effectiveness scales ranged from 1to 7: service quality and effectiveness: Poor $\Rightarrow$ Excellent; user satisfaction: not satisfied $\Rightarrow$ satisfied). 


\begin{tabular}{|c|c|c|c|c|c|c|}
\hline \multicolumn{2}{|l|}{ ANOVA } & $\begin{array}{l}\text { Sum of } \\
\text { Squares }\end{array}$ & $d f$ & $\begin{array}{l}\text { Mean } \\
\text { Square }\end{array}$ & $F$ & Sig. \\
\hline \multirow{3}{*}{$\begin{array}{l}\text { Overall Service Quality } \\
\text { * Company Type }\end{array}$} & $\begin{array}{l}\text { Between } \\
\text { Groups }\end{array}$ & 10.832 & 2 & 5.416 & 4.613 & .011 \\
\hline & Within Groups & 281.763 & 240 & 1.174 & & \\
\hline & Total & 292.595 & 242 & & & \\
\hline \multirow{3}{*}{$\begin{array}{l}\text { Service Quality Factor } \\
\text { \#1 } \\
\text { * Company Type }\end{array}$} & $\begin{array}{l}\text { Between } \\
\text { Groups }\end{array}$ & 12.769 & 2 & 6.384 & 4.442 & .013 \\
\hline & Within Groups & 365.075 & 254 & 1.437 & & \\
\hline & Total & 377.844 & 256 & & & \\
\hline \multirow{3}{*}{$\begin{array}{l}\text { Tangibles Factor \# } 2 \\
\text { * Company Type }\end{array}$} & $\begin{array}{l}\text { Between } \\
\text { Groups }\end{array}$ & 7.496 & 2 & 3.748 & 3.688 & .026 \\
\hline & Within Groups & 254.062 & 250 & 1.016 & & \\
\hline & Total & 261.558 & 252 & & & \\
\hline \multirow{3}{*}{$\begin{array}{l}\text { User Satisfaction } \\
\text { * Company Type }\end{array}$} & $\begin{array}{l}\text { Between } \\
\text { Groups }\end{array}$ & 11.023 & 2 & 5.511 & 3.491 & .032 \\
\hline & Within Groups & 415.173 & 263 & 1.579 & & \\
\hline & Total & 426.195 & 265 & & & \\
\hline \multirow{3}{*}{$\begin{array}{l}\text { Overall Effectiveness } \\
\text { * Company Type }\end{array}$} & $\begin{array}{l}\text { Between } \\
\text { Groups }\end{array}$ & 10.294 & 2 & 5.147 & 4.247 & .015 \\
\hline & Within Groups & 286.020 & 236 & 1.212 & & \\
\hline & Total & 296.314 & 238 & & & \\
\hline
\end{tabular}

Table 11: Statistical Significance between Company Types 
Although the number of organizations of each type was small and participation was voluntary resulting in a selection bias, there could be several reasons for the company type differences, such as:

- Different types of organizational policies and procedures.

- Job security and pay scale differences

- Different levels of pressure to perform

- Different levels of turnover

In one organization, a senior manager reported his opinion having worked in both the private and public sectors.

"The staff is more senior in the government. This is good and bad. They have a lot of experience. They are very dedicated. They work long hours. They're not always recognized or compensated for the effort they put in. However, the downside is the tendency to depend on what is in your head as opposed to what is written down. So I think the environment is less well documented with less structured support." (Manager, org \#8, medium government, medium effectiveness)

The difference between government, private, and other companies with respect to computer support effectiveness are examined in more detail in the following sections during the examination of the independent variables for computer support effectiveness: organizational structure, management attitudes / practices, computer support personnel, end user experience / needs, and resources. 


\subsection{Organizational Structure}

\subsubsection{Discussion}

The organizational structure of the support department(s) varied across the organizations. This section discusses the following research questions:

- Research Question \#1: How do different organizations structure their IS departments with respect to the computer support function?

- Research Question \#2: How does the organizational structure of the IS department influence the effectiveness of the computer support function?

The organizational structure analysis examined the IS department structure with respect to organization size, centralization, reporting structure, rank of IS executive, and outsourcing.

\subsubsection{Organization Size}

Each support department supported a particular user base. The size of the user community supported in each organization ranged from 95 to 10,000 users. User bases (categorized by their size) exhibited different computer support effectiveness ratings as displayed in Table 12. An interesting point to note is that all of the organizations with low effectiveness ratings supported a large user base. There were no occurrences of low effectiveness support functions in either the small or medium organizations whereas there were no occurrences of high effectiveness support functions in large organizations. 
The following table displays the categorization of the twelve participating organizations by size, type, and computer support effectiveness.

\begin{tabular}{|l|c|l|c|}
\hline $\begin{array}{c}\text { Size: } \\
\text { of Users }\end{array}$ & $\begin{array}{c}\text { \# of } \\
\text { Organizations }\end{array}$ & \multicolumn{1}{|c|}{ Type } & Effectiveness \\
\hline Small $(0-399)$ & 3 & $\begin{array}{l}2 \text { other } \\
1 \text { private }\end{array}$ & $\begin{array}{c}2 \text { high } \\
1 \text { medium }\end{array}$ \\
\hline Medium $(400-999)$ & 4 & $\begin{array}{l}3 \text { government } \\
1 \text { other }\end{array}$ & $\begin{array}{c}2 \text { high } \\
2 \text { medium }\end{array}$ \\
\hline Large $(>1,000)$ & 5 & $\begin{array}{l}2 \text { government } \\
1 \text { other } \\
2 \text { private }\end{array}$ & $\begin{array}{c}1 \text { medium } \\
4 \text { low }\end{array}$ \\
\hline
\end{tabular}

Table 12: Supported User Base and Effectiveness

Correlations were run between user size, computer support effectiveness, and service quality-expectations. As displayed in the following table, a significant relationship existed between organization size and effectiveness $\left({ }^{*} \mathrm{p}<0.05\right)$ but there was no significant relationship between organization size and expectation levels.

\begin{tabular}{|l|l|r|}
\hline \multicolumn{1}{|c|}{ Correlations } & \multicolumn{2}{c|}{ Overall Effectiveness } \\
\hline \multirow{4}{*}{ SIZE } & $\begin{array}{l}\text { Pearson } \\
\text { Correlation }\end{array}$ & $-.131\left(^{*}\right)$ \\
\cline { 2 - 3 } & Sig. (2-tailed) & .042 \\
\cline { 2 - 3 } & $\mathrm{N}$ & 239 \\
\hline \multirow{3}{*}{$\begin{array}{l}\text { Service Quality } \\
\text { Expectations }\end{array}$} & $\begin{array}{l}\text { Pearson } \\
\text { Correlation }\end{array}$ & .108 \\
\cline { 2 - 3 } & Sig. (2-tailed) & .086 \\
\cline { 2 - 3 } & $\mathrm{N}$ & 252 \\
\hline
\end{tabular}

${ }^{10}$ Mutually exclusive 
Since all the low computer support effectiveness organizations were large, is the low effectiveness simply a factor of size? It does not appear to be since there was one large organization with a medium effectiveness rating. It may be harder to provide computer support in larger organizations but it is still possible to obtain better effectiveness ratings. As smaller and medium sized organizations grow, they may experience more computer support-related issues and could learn from the issues larger organizations are facing.

It is logical that larger organizations were harder to support but what factors particular to large organizations caused this difficulty? Some possible reasons for the negative influence of large organizations on computer support effectiveness include:

- The need for higher volumes of staff resulting in understaffing and/or higher levels of Human Resource issues

- Funding issues

- Implementation of formal measures to manage large user base (e.g., help desk) resulting in a more formal and impersonal environment where the support staff and end users do not know each other well or at all.

- Formal plans and policies resulting in red tape, lack of flexibility and longer turnaround times

- More complex communication needs: more people, more levels, lack of information flowing "around the water cooler". 
The below quotes offer some insights inio how some of the large organizations viewed their issues and priorities. Common themes were communication, support personnel skill sets, problem prioritization, role definition, and departmental structure.

"Improving communication in the service organization is the next area to tighten up. When [a support person] tells the user that $\mathrm{X}$ is going to happen but another part of the [service] organization doesn't understand and tells the user something else, the user says 'Hey wait a minute'." "It is not easy to make a user community understand what [IT is] doing." (Managers, org \#4, large government, low effectiveness)

"Trying to find right skill set on help desk to respond quickly to users." (Manager, org \#6, large government, low effectiveness)

"Prioritization of problems difficult." "We [IT] used to tell business what to do, now more of a team approach (business-driven)." (Managers, org \#10, large private, low effectiveness).

"[One step to improve the support department's effectiveness was] reorganizing departments. Smaller groups allow you to keep a closer eye on the volume of work and give personal attention which keeps morale up." (Manager, org \# 2, large other, medium effectiveness)

Large organizations with low effectiveness were in the midst of implementing measures to improve their support effectiveness. One decentralized support organization was centralizing (Org \#4, large government, low effectiveness). As a result of department merging, one organization had two separate support structures located in two locations in the same city as well as two different technology bases (Org \#6, large government, low effectiveness). They were trying to bring them together both organizationally and technology standards-wise. The help desk in one organization (Org \#12, large private, 
low effectiveness) was new so they were familiarizing the users with using this procedure.

Since large organizations had lower levels of computer support effectiveness and organizational size cannot usually be changed, larger organizations need to pay particular attention to the computer support effectiveness issue. Structuring large support departments so that everyone understands whom, what, and how support is provided is important. There is a need to set realistic expectations for the users so that they understand the potential of technology and that problems will arise.

The difference between small, medium, and large sized organizations in relation to computer support effectiveness are examined in more detail in the remaining sections examining the independent variables.

\subsubsection{Centralization/Decentralization}

Nine of the participating organizations had centralized support with the remaining companies using a decentralized format. The effectiveness ratings were split evenly between centralization and decentralization. The centralization / decentralization factor was not related to the organization size in this study as displayed in Table 13. All private organizations had centralized support. Some decentralized organizations reported issues with the structure of the IT department across the regions, such as lack of common structure depending on the region.

"[Seeing problems because] the structure for IT not orthogonal; it is not identical in each region" (Manager, org \#6, large government, low effectiveness) 
Some organizations moved from decentralized to centralized formats and some tried to

find a balance between the two.

"[One past problem we encountered was] trying to represent clients who in most cases wanted more decentralization and more autonomy over their equipment and services and, at the same time, representing a group that has a fairly centralized policy (easier to work when clearly defined rules).... [To handle problem] juggle and try and keep both sides honest." (Manager, org \# 2, large other, medium effectiveness)

"[Try to] find right balance of principles. Combine principles in centralized world (foundation of our success) to distributed environment (common principle upon which to execute)." (Manager, org \# 10, large private, low effectiveness)

"[Past problems included] changing industry and company and making users understand IT role. We moved to centralization. It works much better and is cost effective. Back when we were decentralized, there were no standards. We implemented standards and are trying to enforce. User groups have say in what they want with business analysts having ultimate say." (Manager, org \# 12, large private, low effectiveness)

The following table displays the categorization of the twelve participating organizations by centralization/decentralization.

\begin{tabular}{|c|c|c|c|c|}
\hline Structure & $\begin{array}{c}\text { \# of } \\
\text { Organizations }^{11}\end{array}$ & Size & Type & Effectiveness \\
\hline Centralization & 9 & $\begin{array}{c}4 \text { large } \\
3 \text { medium } \\
2 \text { small } \\
\end{array}$ & $\begin{array}{l}3 \text { government } \\
3 \text { other } \\
3 \text { private } \\
\end{array}$ & $\begin{array}{c}3 \text { high } \\
3 \text { medium } \\
3 \text { low } \\
\end{array}$ \\
\hline Decentralization & 3 & $\begin{array}{c}1 \text { large } \\
1 \text { medium } \\
1 \text { small }\end{array}$ & $\begin{array}{l}2 \text { government } \\
1 \text { other }\end{array}$ & $\begin{array}{c}1 \text { high } \\
1 \text { medium } \\
1 \text { low }\end{array}$ \\
\hline
\end{tabular}

Table 13: Centralization Breakdown

${ }^{11}$ Mutually exclusive 
No relationship was found between centralization and computer support effectiveness.

\subsubsection{Support Department Structure}

The structure of the support departments under the IT department was examined. All organizations, with the exception of one small organization, had multiple departments providing computer support. Support personnel were a mixture of job levels. The majority of the support positions were technical with some supervisory or managerial positions. All of the departments supported a variety of software, platforms, hardware, and networks with the software focused primarily on desktop applications, off-the-shelf products, and homegrown applications. There were insufficient differences between the organizations in these areas to determine possible patterns.

One department reported experiencing problems in deliver effective support in the past and were attempting to solve them through a recent department amalgamation." (Manager, org \# 6, large government, low effectiveness).

Another organization (Support personnel, org \#1, small other, medium effectiveness) saw service improvements when the application and support departments were moved under a single director who reinforced the need for support personnel to be involved in the application development and deployment process from the beginning. The impact of the close alignment of support and application groups and its influence on the effectiveness of the support function should be examined in future studies. 
The IS departments in all participating organizations, with the exception of two, had a central help desk or hotline in place.

"We have been reducing the number of outstanding calls by organizing a help desk. [We] had good people but [they were] not properly managed... [Solved by] (1) putting processes, procedures in place; (2) reviewed services, assigned people, and setup responsibility and accountability; (3) put change control mechanisms in place; (4) incorporated client feedback form for satisfaction numbers." (Manager, org \# 6, large government, low effectiveness)

The two organizations that did not have a help desk or central telephone number in place were small organizations where users contacted the computer support personnel directly. Table 14 displays the categorization of the twelve participating organizations by contact mechanism and effectiveness, size, and company type.

\begin{tabular}{|l|c|l|l|c|}
\hline Contact Structure & $\begin{array}{c}\text { \# of } \\
\text { Organizations }^{\mathbf{1 2}}\end{array}$ & \multicolumn{1}{|c|}{ Size } & \multicolumn{1}{c|}{ Type } & Effectiveness \\
\hline Help Desk & 9 & $\begin{array}{l}\text { 1 small } \\
\text { 3 medium } \\
\text { 5 large }\end{array}$ & $\begin{array}{l}4 \text { government } \\
\begin{array}{l}3 \text { other } \\
\text { 2 private }\end{array}\end{array}$ & $\begin{array}{c}2 \text { high } \\
3 \text { medium } \\
4 \text { low }\end{array}$ \\
\hline Central Telephone \# & 1 & 1 medium & 1 government & 1 medium \\
\hline Direct Contact & 2 & 2 small & $\begin{array}{l}\text { 1 other } \\
\text { 1 private }\end{array}$ & 2 high \\
\hline
\end{tabular}

Table 14: User Support Contact Mechanism

The organizations with a help desk or hotline in place also used other structures to provide support, such as:

- Support levels with combinations of help desk, $1^{\text {rst }}$ level, $2^{\text {nd }}$ level, and $3^{\text {rd }}$ level support. There was a tendency for junior people to work on the help desk and

\footnotetext{
${ }^{12}$ Mutually exclusive
} 
then move into other areas. This is discussed further in the section on 'Computer Support Personnel'.

- Client liaison or business analyst personnel within the computer support structure in IS who related the users' business needs to technical needs and vice versa. This was reported by three organizations: org \#12, large private, low effectiveness; org \#2, large other, medium effectiveness, and org \#1, small other, medium effectiveness)

- Assignment of computer support personnel to specific business / functional areas so that the users continually deal with the same person. This was reported by two organizations: org \#4, large government, low effectiveness, and org \#1, small other, medium effectiveness). It is interesting to note that the large organization that assigned a dedicated 1st line support person to each floor had a low effectiveness rating. In this scenario, the users knew who to contact eliminating some of communication issues prevalent in large organizations. It also provided a more personal environment as the support personnel and users knew each other as a result of more frequent contact with the same person. It was thought that this would result in better support. But, in this scenario, the support was only as good as the person providing it. If users had a bad experience with a particular support person but was forced to always deal with them, this would worsen the situation and the perceived service quality. Other possible explanations could relate to the interchangeability of 
skills/knowledge or appearance of rigid/inflexible control. In organizations where dedicated support personnel are employed, additional analysis must be performed on the quality of service categorized by the individual person providing the support.

- Two separate geographically located help desks. Reported by one organization: org \#6, large government, low effectiveness)

- Implementation of user support centers (USCs). Reported by one organization: org \#3, medium other, high effectiveness. One manager in this organization reported that the USCs were extremely useful but, in spite of this, they had to keep "justifying the USC's existence. We have to justify people helping people".

Help desks are required in larger organizations where informal mechanisms for support contact are no longer feasible. The presence of a help desk does not automatically equate to good or bad support effectiveness. Does a good help desk automatically mean effective support? Future studies should investigate the users' perception of the effectiveness of the support received from the help desk versus support received by other support personnel.

"The help desk is the image of the [support] organization." (Manager, org \#4, large government, low effectiveness)

"[Support effectiveness is] good generally since restructure and this new guy came on board with people skills doing 1st line support because the other guys are joetechies. [One person can make] all the difference in the world." (Manager, org \#11, small, private, high effectiveness 
Although it was not found that the presence of a help desk influenced the support effectiveness, due to comments concerning the importance of the initial user contact, the overall support effectiveness appears to be weighted in favor of the users' impression of the service received from the first level of contact.

Managers should pay particular attention to the service and resulting user impressions of their front line staff. In most cases, this staff would be the help desk. Users want to know that the person on the other end of the phone will walk them through solutions to routine problems and/or record all prevalent information to relay onto other support personnel who can solve their problem in a timely manner. Many users appreciate a follow up call to be kept up to speed with the status of their problem. Users do not appreciate having to repeat the same information many times or having to phone to find out what it going on with their problem. Help desk personnel must have good people skills to be able to calm down frustrated or upset users to be able to obtain the necessary information and leave them with the sense that their problems will be looked after. It is also important that help desk personnel provide the end users with a realistic and tangible timeframe of when their problem will be fixed and follow up if there will be delays. Users often look to the first person recording their problem as the person who will follow it through to the end. 


\subsubsection{Rank of is Executive}

The support departments in all organizations were organized under an Informatics or IS Department banner reporting to a high-ranking executive (DM/ADM, VP, CIO) indicating that the organizations did see the importance of the support function. There was not enough differentiation in the rank of the IT executive to see any patterns with support effectiveness.

\subsubsection{Outsourcing}

The majority of the organizations (ten of twelve) used some form of outsourcing with one additional organization investigating the possibility of outsourcing. Table 16 displays the different types of contracting or outsourcing arrangements. The majority of the organizations used outsourcing / contracting on a per-project basis or to fill in staffing gaps. Some organizations, primarily government departments, outsourced functions or complete departments. Two organizations did not currently use contractors or outsourcing and were both private. The following table displays which organizations used outsourcing and/or contracting. 


\begin{tabular}{|c|c|c|c|c|}
\hline $\begin{array}{l}\text { Used Outsourcing } \\
\text { and/or Contracting }\end{array}$ & $\begin{array}{c}\text { \# of } \\
\text { Organizations }^{13}\end{array}$ & Size & Type & Effectiveness \\
\hline Yes & $\begin{array}{c}10 \\
(\operatorname{org} \# 1,2,3,4 \\
5,6,7,8,9,10)\end{array}$ & $\begin{array}{l}2 \text { small } \\
4 \text { medium } \\
4 \text { large }\end{array}$ & $\begin{array}{l}4 \text { other } \\
5 \text { government } \\
1 \text { private }\end{array}$ & $\begin{array}{l}3 \text { high } \\
4 \text { medium } \\
3 \text { low }\end{array}$ \\
\hline No & $\begin{array}{c}2 \\
\left(\operatorname{org} \# 11,12^{14}\right)\end{array}$ & $\begin{array}{l}1 \text { small } \\
1 \text { large }\end{array}$ & 2 private & $\begin{array}{l}1 \text { high } \\
1 \text { low }\end{array}$ \\
\hline
\end{tabular}

Table 15: Use of Outsourcing in Organizations

The following table displays the type of outsourcing and/or contracting implemented by the ten organizations using outsourcing.

\footnotetext{
${ }^{13}$ Mutually exclusive

${ }^{14}$ Investigating use of outsourcing or contracting
} 


\begin{tabular}{|c|c|c|c|c|}
\hline $\begin{array}{c}\text { Types of } \\
\text { Outsourcing and/or } \\
\text { Contracting Use }\end{array}$ & $\begin{array}{c}\text { \# of } \\
\text { Organizations }^{15}\end{array}$ & Size & Type & Effectiveness \\
\hline Use on a project-basis & 7 & $\begin{array}{l}1 \text { small } \\
3 \text { medium } \\
3 \text { large } \\
\end{array}$ & $\begin{array}{l}2 \text { other } \\
4 \text { government } \\
1 \text { private } \\
\end{array}$ & $\begin{array}{l}1 \text { high } \\
3 \text { medium } \\
3 \text { low }\end{array}$ \\
\hline $\begin{array}{l}\text { Use contractors / } \\
\text { consultants to fill in } \\
\text { staffing gaps }\end{array}$ & 5 & $\begin{array}{l}1 \text { small } \\
2 \text { medium } \\
2 \text { large } \\
\end{array}$ & $\begin{array}{l}2 \text { other } \\
2 \text { government } \\
1 \text { private } \\
\end{array}$ & $\begin{array}{l}3 \text { high } \\
2 \text { low }\end{array}$ \\
\hline $\begin{array}{l}\text { Development partially } \\
\text { or fully contracted out }\end{array}$ & 3 & $\begin{array}{l}1 \text { medium } \\
2 \text { large }\end{array}$ & $\begin{array}{l}2 \text { other } \\
1 \text { government }\end{array}$ & $\begin{array}{l}1 \text { high } \\
1 \text { medium } \\
1 \text { low } \\
\end{array}$ \\
\hline $\begin{array}{l}\text { System maintenance } \\
\text { partially or fully } \\
\text { contracted out }\end{array}$ & 1 & 1 medium & 1 other & 1 high \\
\hline $\begin{array}{l}\text { Tech support partially } \\
\text { or fully contracted out }\end{array}$ & 3 & $\begin{array}{l}2 \text { large } \\
1 \text { medium }\end{array}$ & 3 government & $\begin{array}{l}1 \text { high } \\
2 \text { low }\end{array}$ \\
\hline $\begin{array}{l}\text { Operations partially } \\
\text { or fully contracted out }\end{array}$ & 1 & 1 medium & 1 government & 1 high \\
\hline $\begin{array}{l}\text { Moving to use more } \\
\text { consultants or } \\
\text { outsourcing pieces of } \\
\text { work }\end{array}$ & 3 & $\begin{array}{l}1 \text { small } \\
1 \text { medium } \\
1 \text { large }\end{array}$ & $\begin{array}{l}2 \text { other } \\
1 \text { government }\end{array}$ & $\begin{array}{l}1 \text { high } \\
2 \text { medium }\end{array}$ \\
\hline
\end{tabular}

Table 16: Outsourcing / Contracting Type

Negative management comments regarding outsourcing focused on the following areas:

- Cost

Costs more, expensive, not enough value for money. (Manager, org

\#6, large government, low effectiveness and Manager, org \#8, medium government, medium effectiveness)

${ }^{15}$ Not mutually exclusive 
- Don't have company loyalty or corporate memory

"Don't agree with it [outsourcing], don't get value for money, don't have loyalty, corporate memory, etc". (Manager, org \#6, large government, low effectiveness)

- Creates conflict in staff because consultants getting good money and best project (Manager, org \#9, high government, medium effectiveness)

- Consultants take all information on systems when they leave. There is a void in support when systems to into production.

Reported by Org \#3 (Manager, high other, medium effectiveness)

- Causes insecurity in full-time staff with a possible impact to morale

Reported by Org \#4 (Manager, low government, low effectiveness) and Org \# 2 (Manager, large other, low effectiveness)

Management also provided several positive reasons for the use of outsourcing or contracting. Examples included:

- To enable them to meet timelines and user expectations

Reported by Org \#12 (Manager, large private, low effectiveness)

- To employ better business practices

"Vendors can apply disciplines (documented, structured) better than we can." (Manager, org \#8, medium government, medium effectiveness)

- To staff difficult positions

"[We are] thinking about outsourcing help desk, it will depend on the flexibility of the calls. Dispatcher on help desk is probably 
hardest position to staff. This is very demanding, very high emotional. It must be very tough to keep people ongoing on a help desk. That's why we're looking at outsourcing." (Org \#8, management, medium government, medium effectiveness)

- To obtain appropriate technical skills

"Technical skills in government are hard to keep up which is why we do a lot of contracting. Contracting is good because can pick and choose skills but bad because skills not always available. It creates conflict in staff because consultants getting good money and best projects" (Org \# 9, management, medium government, high effectiveness)

- To have enough internal personnel for other functions

"[Contracting] allows us to reassign support work to corporate staff. Business analysis and design are done by corporate and we contract out coding." (Org \#2, management, medium other, low effectiveness)

"Use consultants to ensure that there are enough people where they need to be." (Org \#3, management, high other, medium effectiveness)

A few managers recommended that outsourcing only be used in certain

circumstances, such as to fill in staffing gaps or for projects. Organizations must be able to define problems and processes before being able to effectively using outsourcing.

"You can't outsource a problem. If you have a problem, you're not going to solve it by outsourcing. You solve the problem and then outsource the process". (Org \#6, management, large government, low effectiveness)

"Good for repetitive tasks or on a project-type basis." (Org \#4, management, large government, low effectiveness)

There did not appear to be a direct relationship between type and frequency of outsourcing and contracting to the effectiveness of the support organizations. There may 
be an indirect relationship if the use of outsourcing negatively impacts the morale of support personnel. This will be examined in the Computer Support Personnel section on page 156.

\subsubsection{Summary of Organizational Structure Hypotheses}

The following hypotheses were proposed regarding organizational structure and computer support effectiveness. Hypotheses tagged 'NEW' were not validated based on the study's data but were evaluated to be worth further study based on a combination of interview comments and past research.

1. The company type impacts the level of computer support effectiveness with other organizations performing better than government or private.

2. The size of the organization has a negative relationship with the level of computer support effectiveness.

3. NEW: Close alignment of the support and application groups improves the effectiveness of the support function.

\subsection{Management Attitude / Practices}

\subsubsection{Discussion}

Management attitudes and practices were investigated (research question \#3) to determine possible relationships with computer support effectiveness. The following areas were examined:

- Policies and planning 
- Management practices

- Communication

\subsubsection{Policies and planning}

Nine of the twelve organizations used some form of formal Information Management / Information Technology / Architecture plan. The content of these plans included standards, priorities, and future vision for technology applications, connectivity, and structure. Of the remaining three organizations, one was in the process of defining a plan and two did not have a plan. The breakdown by organization and effectiveness is displayed in Table 17.

\begin{tabular}{|l|c|l|l|l|}
\hline $\begin{array}{c}\text { Information } \\
\text { Technology Plan }\end{array}$ & $\begin{array}{c}\text { \# of } \\
\text { Organizations }\end{array}$ & \multicolumn{1}{|c|}{ Size } & \multicolumn{1}{|c|}{ Type } & Effectiveness \\
\hline Formal plan in place & 9 & $\begin{array}{l}1 \text { small } \\
3 \text { medium } \\
5 \text { large }\end{array}$ & $\begin{array}{l}\text { 3 other } \\
4 \text { government } \\
2 \text { private }\end{array}$ & $\begin{array}{l}2 \text { high } \\
3 \text { medium } \\
4 \text { low }\end{array}$ \\
\hline $\begin{array}{l}\text { Formal plan in } \\
\text { progress }\end{array}$ & 1 & 1 small & 1 other & 1 high \\
\hline No plan & 2 & $\begin{array}{l}1 \text { small } \\
1 \text { medium }\end{array}$ & $\begin{array}{l}1 \text { government } \\
1 \text { private }\end{array}$ & $\begin{array}{l}\text { 1high } \\
1 \text { medium }\end{array}$ \\
\hline
\end{tabular}

Table 17: Information Technology Plan

Although organizations with formal plans in place displayed all levels of support effectiveness, many managers felt strategic plans helped them provide effective support.

The key was that the plans must be updated regularly to keep pace with the ever-changing

\footnotetext{
${ }^{16}$ Mutually exclusive
} 
technology implications. The frequency of updates to the strategic plan as well as the intended audience of the plan (e.g., executives, IS management) should be investigated in future research.

Managers in all organizations, with the exception of one, reported organizational policies hindering their ability to be as effective as possible. The main categories reported were staffing and procurement policy issues as displayed in Table 18.

\begin{tabular}{|c|c|l|l|l|}
\hline $\begin{array}{c}\text { Organizational } \\
\text { Policies Hindering } \\
\text { Effectiveness }\end{array}$ & $\begin{array}{c}\text { \# of } \\
\text { Organizations }\end{array}$ & \multicolumn{1}{|c|}{ Size } & \multicolumn{1}{|c|}{ Type } & Effectiveness \\
\hline Staffing Policies & 7 & $\begin{array}{l}1 \text { small } \\
4 \text { medium } \\
\text { 2 large }\end{array}$ & $\begin{array}{l}\text { 2 other } \\
5 \text { government }\end{array}$ & $\begin{array}{l}2 \text { high } \\
3 \text { medium } \\
\text { 2 low }\end{array}$ \\
\hline Procurement & 8 & $\begin{array}{l}\text { 1 small } \\
4 \text { medium } \\
\text { 3 large }\end{array}$ & $\begin{array}{l}\text { 2 other } \\
5 \text { government } \\
\text { 1 private }\end{array}$ & $\begin{array}{l}\text { 3 high } \\
\text { 2 medium } \\
\text { 3 low }\end{array}$ \\
\hline
\end{tabular}

Table 18: Organizational Policies

Issues with staffing policies were reported in seven organizations including all government organizations. The main issues reported were:

- Difficulty in the ability to hire, fire, and promote

- Lengthy consultant contracting processes

- Inability to increase number of staff

Although a direct relationship between reported staffing policy restrictions and support effectiveness was not found, this issue should not be ignored. The more important

${ }^{17}$ Not mutually exclusive 
question is whether or not the organization had enough staff to perform their work. This is investigated in section 4.8.1.2.

Eight organizations reported issues regarding their current procurement processes including all government organizations. Organizational sizes were mostly medium and large. Reported procurement problems included:

- Standards limiting choice of resources that can be purchased or vendors that can be used

- Lengthy and onerous procurements processes especially for more expensive resources $(>\$ 5 \mathrm{~K})$

- Difficulty in getting resources in a quick timeframe

Similarly to the staffing policies, no direct relationship was found between reported procurement process issues and effectiveness. The question of whether the organization had enough resources to perform their job is explored in section 4.8.1.1.

Funding policy issues were reported by two private organizations and one other organization. Since the funding policy question was not posed directly in the interview process, several other organizations may also agree with the limitation. Funding issues are investigated further in section 4.8.1.3.

Management in two organizations (one government and one other) reported that their organization's bilingual language policies hindered their work.

A direct relationship was not found between management policies and planning and computer support effectiveness. The more accurate question may be whether or not the 
organizations had enough staffing, resources, etc. to perform their job. The restrictive organizational policies may impede management's ability to provide the required resources but would not stop them. A valuable measurement in future studies would be an evaluation of the level of formal processes and procedures, beyond strategic plans, in place for the IS department.

\subsubsection{Management Practices}

Several areas were investigated to examine specific management practices, including:

- $\quad$ Reactive / proactive support

- Service orientation

- $\quad$ Hiring practices

- Measurement of success

- Direction

- Competence

\subsection{Reactive versus proactive support}

Managers were asked if support in their organizations was done in a proactive manner as well as reactive. In all reporting organizations, they were trying to be proactive but had issues due to lack of time. All organizations responded with different 
methods for proactive computer support. The most popular forms of proactive support were:

- Technology standards

- Training

- User involvement

- IT restructuring

- Preventative maintenance and system monitoring

Computer technology changes at an extremely high rate. Most organizations felt the need to try and control the environment to manage this rate of change. Seven (of twelve) organizations reported using standard technology configurations with one additional organization in the process of converting to a standard platform. The following table displays which organizations had implemented technology standards.

\begin{tabular}{|l|c|l|l|l|}
\hline \multicolumn{1}{|c|}{$\begin{array}{c}\text { Technology } \\
\text { Standards }\end{array}$} & \multicolumn{1}{c|}{$\begin{array}{c}\text { \# of } \\
\text { Organizations }\end{array}$} & \multicolumn{1}{c|}{ Size } & \multicolumn{1}{c|}{ Type } & Effectiveness \\
\hline $\begin{array}{l}\text { Use technology } \\
\text { standards }\end{array}$ & 7 & $\begin{array}{l}2 \text { small } \\
2 \text { medium } \\
3 \text { large }\end{array}$ & $\begin{array}{l}\text { 2 government } \\
3 \text { other } \\
2 \text { private }\end{array}$ & $\begin{array}{l}2 \text { high } \\
2 \text { medium } \\
3 \text { low }\end{array}$ \\
\hline $\begin{array}{l}\text { Are moving towards } \\
\text { technology standards }\end{array}$ & 1 & 1 medium & 1 government & 1 medium \\
\hline $\begin{array}{l}\text { No technology } \\
\text { standards }\end{array}$ & 4 & $\begin{array}{l}1 \text { small } \\
1 \text { medium } \\
2 \text { large }\end{array}$ & $\begin{array}{l}\text { 2 government } \\
1 \text { other } \\
1 \text { private }\end{array}$ & $\begin{array}{l}2 \text { high } \\
1 \text { medium } \\
1 \text { low }\end{array}$ \\
\hline
\end{tabular}

Table 19: Proactive - Standard Technology Configuration

${ }^{18}$ Mutually exclusive 
Standards were used to restrict the amount or variety of technology supported. The breadth of the technology choices impacts the complexity of support.

"[Complexity is] not based on the number of users you have but based on how much technology you provide... [With more technology], the support becomes more and more complicated. The resources in terms of staff are required to be more knowledgeable and you require more sophisticated tools to provide support. [Solving by] implementing remote software to make the deployment of technology more synchronized and intelligent." (Manager, org \#1, small other, medium effectiveness)

"Interoperability a huge issue; technology is diverse and not always compatible (Manager, org \#12, large private, low effectiveness)

"Too many systems, hard to know how everything runs." (Support personnel, org $\# 12$, large private, low effectiveness)

"We are struggling to keep our head above water". "We are firefighting between three different environments. A standard environment should improve things to make it easer to be proactive". (Manager, org \#8, medium government, medium effectiveness)

"[Support will be] easier when we have a common platform. Now with all the variety it's hard to maintain." (Support personnel, org \#8, medium government, medium effectiveness)

Technology standards allow organizations to restrict the types and brands of computer software, hardware, and networking used. Several organizations reported benefits with the use of technology standards

"Standards have really improved things in many areas" (Manager, org \#6, large government, low effectiveness)

"Standardization saved our bacon". "We can't support everything... drive through standards." (Manager, org \#3, medium other, high effectiveness)

"Started standardizing form beginning." (Manager, org \#5, medium government, medium effectiveness) 
While all organizations that implemented standards believed strongly in their value, a few downsides were reported. One organization felt it was more difficult to maintain the standards then to initially implement them. A few organizations reported that technically literate users wanted to use their choice of technology. This was reported to be an even larger issue in the case of user cost recovery where users funded their own IT expenditures. Managers reported:

"Recommendations for standards are loose. It would be nice to have one configuration instead of several. Users are paying for own things so can't make them following standards." (Support personnel, org \#4, large government, low effectiveness)

"A user will see something in Computer City and have to have it. The single biggest thing we should do in this organization is to get rid of PC Magazine." (Manager, org \#1, small other, medium effectiveness)

"Everyone thinks they have their own needs but they can be met with a standard" (Manager, org \#5, medium government, medium effectiveness)

Although a direct relationship between the use of technology standards and computer support effectiveness was not found, most organizations bought into the value of standards and were trying to find ways of managing user expectations and obtaining user buy-in to support the use of technology standards. The relationship between technology standards and computer support effectiveness appeared to be more complicated than the other proactive measures. The following potential hypotheses should be investigated in future research: 
- The use of technology standards reduces the amount and difficulty of support required.

- The more restrictive the standards, the less support required.

- The more restrictive the standards, the lower the user satisfaction of advanced users.

- If the standards provide technology that meets user's expectations and needs, the use of standards has a positive relationship with support effectiveness.

User training was performed in all twelve participating organizations to be proactive. Training from both users and IT (e.g., help desk) was provided during new technology rollouts in seven of the organizations. IT made recommendations to the training department regarding courses based on analysis of logged problems in six organizations. More detailed analysis on training is found in section 4.7.1.4.

User involvement, as a form of proactive behaviour, was reported in six organizations. This involvement ranged from user participation and commitment in application development and deployments to user feedback and proactive visits. The most successful form of user involvement in relationship to support effectiveness was the process of obtaining user commitment as part of implementation project and plans. This should be investigated in future studies as a potential hypothesis in the computer support model. The following table describes the type of user involvement implemented in the various organizations. 


\begin{tabular}{|c|c|c|c|c|}
\hline User Involvement & $\begin{array}{c}\text { \# of } \\
\text { Organizations }^{19}\end{array}$ & Size & Type & Effectivenes $\varepsilon$ \\
\hline $\begin{array}{l}\text { User / Client Liaison } \\
\text { Group }\end{array}$ & $\begin{array}{c}2 \\
(\operatorname{org} \# 2,12)\end{array}$ & 2 large & $\begin{array}{l}1 \text { other } \\
1 \text { private }\end{array}$ & $\begin{array}{l}1 \text { low } \\
1 \text { medium }\end{array}$ \\
\hline $\begin{array}{l}\text { User Commitment on } \\
\text { Implementation Plans } \\
\text { / Projects }\end{array}$ & $\begin{array}{c}2 \\
\text { (org \#3,7) }\end{array}$ & $\begin{array}{l}1 \text { small } \\
1 \text { medium }\end{array}$ & 2 other & 2 high \\
\hline Client Feedback & $\begin{array}{c}2 \\
\text { (org \# 4,6) } \\
\end{array}$ & 2 large & 2 government & 2 low \\
\hline No Answer Provided & $\begin{array}{c}6 \\
(\text { org } \# 1,5,8,9 \\
10,11) \\
\end{array}$ & $\begin{array}{l}2 \text { small } \\
3 \text { medium } \\
1 \text { large } \\
\end{array}$ & $\begin{array}{l}1 \text { other } \\
3 \text { government } \\
2 \text { private } \\
\end{array}$ & $\begin{array}{l}1 \text { low } \\
3 \text { medium } \\
2 \text { high } \\
\end{array}$ \\
\hline
\end{tabular}

Table 20: Proactive - User Involvement

Organizations reported that in order to be successful, they needed to get the users involvement with IS and the technology so that everyone can see the benefits and understand the complexities.

"[We use] horizontal working groups. Speed of success rate is because getting other people's opinions. Users involved, accepted, and promoted with technology." (Manager, org \#3, medium other, high effectiveness)

"We did not have success for a long time. Users now seeing that they want to make it work and try hard. Users seeing potential of technology and understand problems will arise." (Manager, org \#4, large government, low effectiveness)

"Keeping clients happy. The help desk is the image of the organization. Have to be open mind with clients." (Manager, org \#4, large government, low effectiveness)

${ }^{19}$ Mutually exclusive 
Another proactive mechanism stated by five organizations was TT restructuring and reorganization. One organization converted to smaller groups to keep a closer eye on volume of work and provide personal attention (manager, org \#2, medium, other, low effectiveness) while another organization was implementing a new structure to enable division of proactive and reactive tasks (manager, org\#12, large private, low).

Other proactive controls included:

- Help desk trend analysis (reported by two organizations)

- Monitoring of systems (reported by two organizations)

- Change control processes (reported by one organization)

- Preventative maintenance (reported by two organizations)

- Controls for end user development (reported by one organization)

Whereas all participating organizations attempted to be as proactive as possible, nine of them reported they were firefighting for the most part due to a lack of time, money, and staff. Typical responses were:

"It [proactive support] doesn't happen as much because understaffed... It is hard to keep up with technology side of things" (org \#12, large private, low effectiveness)

"Techs busy fighting fires. Not a lot of time to do preventative maintenance." (Manager, org\#7, small other, high effectiveness)

One organization reported that they had a very reactive environment as a result of the company culture (org \#10, low private, low effectiveness). Some comments were "They 
like fire fighting", "thrives on dealing with crisis", "process as roadblocks" and "actionoriented".

There was general agreement that proactive actions would decrease the amount of support required but it was difficult due to time and resource constraints. Once proactive measures were in place, would the severity of the time and resource constraints lessen? Nine of the twelve organizations reported issues with lack of time (see section 4.8.1.4). Of the seven organizations that implemented technology standards, five also reported a lack of time. These two pieces independently did not reflect the change in the level of time constraints before and after technology standards were implemented. When asked, support managers felt that the technology standards they implemented decreased the amount of support they provided. Although this decrease was present, there were other demands on the support team's time so that the overall time constraint issue was not resolved. The following table displays the relationship between technology standards and time constraints in organizations. 


\begin{tabular}{|c|c|c|c|c|}
\hline $\begin{array}{c}\text { Technology } \\
\text { Standards and Time } \\
\text { Issues }\end{array}$ & $\begin{array}{c}\text { \# of } \\
\text { Organizations }^{20}\end{array}$ & Size & Type & Effectiveness \\
\hline $\begin{array}{l}\text { Use technology } \\
\text { standards and have } \\
\text { time to do job }\end{array}$ & 2 & $\begin{array}{l}1 \text { small } \\
1 \text { large }\end{array}$ & $\begin{array}{l}1 \text { other } \\
1 \text { private }\end{array}$ & $\begin{array}{l}1 \text { medium } \\
1 \text { low }\end{array}$ \\
\hline $\begin{array}{l}\text { Use technology } \\
\text { standards and have } \\
\text { issues with lack of } \\
\text { time }\end{array}$ & 5 & $\begin{array}{l}1 \text { small } \\
2 \\
\text { medium } \\
2 \text { large }\end{array}$ & $\begin{array}{l}2 \text { government } \\
2 \text { other } \\
1 \text { private }\end{array}$ & $\begin{array}{l}2 \text { high } \\
1 \text { medium } \\
2 \text { low }\end{array}$ \\
\hline $\begin{array}{l}\text { Are moving towards } \\
\text { technology standards } \\
\text { and have issues with } \\
\text { lack of time }\end{array}$ & 1 & 1 & 1 government & 1 medium \\
\hline $\begin{array}{l}\text { No technology } \\
\text { standards and have } \\
\text { time to do job }\end{array}$ & 1 & $1 \mathrm{small}$ & 1 private & 1 high \\
\hline $\begin{array}{l}\text { No technology } \\
\text { standards and have } \\
\text { issues with lack of } \\
\text { time }\end{array}$ & 3 & $\begin{array}{l}1 \\
\text { medium } \\
2 \text { large }\end{array}$ & $\begin{array}{l}2 \text { government } \\
1 \text { other }\end{array}$ & $\begin{array}{l}1 \text { high } \\
1 \text { medium } \\
1 \text { low }\end{array}$ \\
\hline
\end{tabular}

Table 21: Technology Standards and Time

Since most organizations attempted to implement proactive support mechanisms, it is not possible to state whether having proactive support versus not resulted in improved support effectiveness. But, proactive support should not be ignored. The relationship between proactive support and support effectiveness may only become apparent when analyzing the different forms of proactive behaviour (e.g., user commitment). In this study, interview participants were not presented with a complete list of proactive behaviour to specify what was implemented in their organization. This is recommended

${ }^{20}$ Mutually exclusive 
for future analysis. A potential hypothesis is that that the level of proactive support relates positively to the effectiveness of the support function. Managers should implement and enforce the following proactive behavior in their support department as well as looking for additional ways to be proactive:

- Implementing technology standards that meet the users' need

- Obtaining user commitment on new project implementations and rollouts

- Performing preventative maintenance and system monitoring

Some quantitative measures that would be useful in future investigations include:

- Proactive behavior measured as: the amount of time and money the IS department spends performing proactive measures; percentage of time spent doing proactive support as opposed to reactive; number of dedicated resources performing proactive support.

- Comparison of level of proactive behavior to call volumes

- Number of organizations using the following types of proactive behavior (as compared to support call volumes and level of support effectiveness):

- Technology standards: breadth and depth of standards

- Pre-rollout training: time spent performing training, level of training, if training continued post rollout

- User involvement: types of user involvement used (e.g., application development, user groups), user sign-off process 
- System monitoring: time spent by staff performing monitoring, cost of monitoring (hardware/software), degree of automation

- Preventative maintenance: time spent performing preventative maintenance

\subsection{Service orientation}

Managers were asked about the importance of the support departments relative to development departments in terms of allocation of resources. The results are displayed in Table 22 .

\begin{tabular}{|c|c|c|c|c|}
\hline Service Orientation & $\begin{array}{c}\text { \# of } \\
\text { Organizations }^{21} \\
\end{array}$ & Size & Type & Effectiveness \\
\hline $\begin{array}{l}\text { Reasonable } \\
\text { distribution of } \\
\text { resources }\end{array}$ & $\begin{array}{c}3 \\
(\operatorname{org} \# 1,8,11)\end{array}$ & $\begin{array}{l}1 \\
\text { medium } \\
2 \text { small } \\
\end{array}$ & $\begin{array}{l}1 \text { private } \\
1 \text { other } \\
1 \text { government }\end{array}$ & $\begin{array}{l}1 \text { high } \\
2 \text { medium }\end{array}$ \\
\hline Support emphasis & $\left(\begin{array}{c}4 \\
(\operatorname{org} \# 4,5,6,7)\end{array}\right.$ & $\begin{array}{l}2 \text { large } \\
1 \\
\text { medium } \\
1 \text { small }\end{array}$ & $\begin{array}{l}1 \text { other } \\
3 \text { government }\end{array}$ & $\begin{array}{l}1 \text { high } \\
1 \text { medium } \\
2 \text { low }\end{array}$ \\
\hline $\begin{array}{l}\text { Development } \\
\text { emphasis }\end{array}$ & 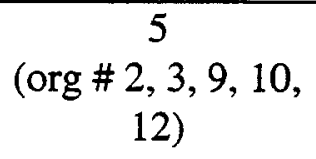 & $\begin{array}{l}3 \text { large } \\
2 \\
\text { medium }\end{array}$ & $\begin{array}{l}2 \text { private } \\
2 \text { other } \\
1 \text { government }\end{array}$ & $\begin{array}{l}2 \text { high } \\
1 \text { medium } \\
2 \text { low }\end{array}$ \\
\hline
\end{tabular}

Table 22: Service Orientation Breakdown

No small organizations had a development-only emphasis whereas no private organizations had a support-only emphasis. There were no low effectiveness ratings for

${ }^{21}$ Mutually exclusive 
organizations reporting reasonable distribution of resources. For organizations reporting a development-only emphasis, one representative quote follows:

"There is far less sympathy, understanding, and empathy, for technology architecture and support services.... partially because our own IT management comes from a development background... Makes lives from a training and support point of view quite difficult. In the end, I think IT will end up getting bad image." (Manager, org \# 2, large other, medium effectiveness)

An IS department would run much smoother if there was a reasonable distribution of resources. If not, one of the groups (support or application) would feel shortchanged causing internal conflict. As well, users view the IS shop as the provider as well as the supporter of their required applications. Unfair distribution of resources would cause uneven delivery of services (applications and/or support). Based on the fact that no low effectiveness organizations reported fair distribution of resources, it is hypothesized that unfair distribution of resources between the application and support components of the IS department lead to decreased support effectiveness.

For every application rollout, money and resources should be allocated in advance for the on-going support and maintenance of these applications. If there are large development efforts, there should be comparable support efforts being planned. If there are few development efforts and the environment is very stable, there should be less support required. 


\subsection{Hiring practices}

What do managers look for when hiring support personnel? Managers used a combination of education, related work experience, technical skills, and/or people skills for hiring purposes.

There were a variety of responses on the subject of education. Several managers looked for post-secondary education or equivalent work experience or a combination of education and experience. There was some disagreement over whether education was more important than experience or experience was more important than education. Two large organizations reported that a degree helped when trying to move laterally or upward.

On the pro-education stance, one hiring manager wanted some level of post secondary education as they felt that a degree showed discipline (Manager, org \#11, small private, high effectiveness). Another had a preference for a college or university degree as it shows they [potential employees] worked towards something and has a base knowledge (org \#12, large private, low effectiveness).

On the pro-experience side, one manager was not a big fan of higher education but likes it if it is there but it is not his first criteria (org \#8, medium government, medium effectiveness). Another manager agreed and said that education is important but not number one; it can be used when comparing others with equivalent technical experience (org \#5, medium government, medium effectiveness).

The breakdowns of education comments by organization are displayed in section Table 23. There did not appear to be a direct relationship between educational hiring 
preferences and support effectiveness. The effect of educational level of support personnel on support effectiveness is examined in the Computer Support Personnel section on page 132. The following table categorizes comments made by the organizations with respect to the education and experience trade-off.

\begin{tabular}{|c|c|c|c|c|}
\hline Comments & $\begin{array}{c}\text { \# of } \\
\text { Organizations }^{22}\end{array}$ & Size & Type & Effectiveness \\
\hline $\begin{array}{l}\text { Combination of experience } \\
\text { \& education }\end{array}$ & $\begin{array}{c}2 \\
(\operatorname{org} \# 10,11)\end{array}$ & $\begin{array}{l}1 \text { large } \\
1 \text { small }\end{array}$ & 2 private & $\begin{array}{l}1 \text { low } \\
1 \text { high }\end{array}$ \\
\hline $\begin{array}{l}\text { Look for college/university } \\
\text { degree or equivalent } \\
\text { experience }\end{array}$ & $\begin{array}{c}3 \\
\text { (org \# 1, 3, 4) }\end{array}$ & $\begin{array}{l}1 \text { small } \\
1 \text { medium } \\
1 \text { large }\end{array}$ & $\begin{array}{l}2 \text { other } \\
1 \text { government }\end{array}$ & $\begin{array}{l}1 \text { low } \\
1 \text { medium } \\
1 \text { high }\end{array}$ \\
\hline $\begin{array}{l}\text { Education helps for upward } \\
\text { or lateral mobility }\end{array}$ & $\begin{array}{c}2 \\
\text { (org \#2,4) }\end{array}$ & 2 large & $\begin{array}{l}1 \text { other } \\
1 \text { government }\end{array}$ & $\begin{array}{l}1 \text { low } \\
1 \text { medium }\end{array}$ \\
\hline $\begin{array}{l}\text { Experience more important } \\
\text { than education }\end{array}$ & $(\operatorname{org} \# 2,5,6,8,9$ & $\begin{array}{l}3 \text { medium } \\
2 \text { large }\end{array}$ & $\begin{array}{l}1 \text { other } \\
4 \text { government }\end{array}$ & $\begin{array}{l}1 \text { low } \\
3 \text { medium } \\
1 \text { high }\end{array}$ \\
\hline $\begin{array}{l}\text { Education more important } \\
\text { than experience }\end{array}$ & $\begin{array}{c}2 \\
(\operatorname{org} \# 7,12) \\
\end{array}$ & $\begin{array}{l}1 \text { small } \\
1 \text { large } \\
\end{array}$ & $\begin{array}{l}1 \text { other } \\
1 \text { private }\end{array}$ & $\begin{array}{l}1 \text { low } \\
1 \text { high }\end{array}$ \\
\hline
\end{tabular}

Table 23: Education versus Experience

On the work experience front, managers looked for people that could see the big picture (reported by three organizations). One manager stated:

"I tend to hire a solid background in the mainframes. The best people that I've had here have mainframe experience because they see the big picture. "... "I like people who have worked in maintenance and support, especially developers - so they've been on the other side." (Org \#1, small other, medium effectiveness)

${ }^{22}$ Not mutually exclusive 
One organization reported that it was important that the candidate know the organization (org \#9, medium government, high effectiveness).

All organizations looked for technical skills when hiring support personnel.

Managers in all organizations also reported that they look for people skills when hiring support personnel. One manager weighted the importance as $40 \%$ technical skills and $60 \%$ people skills (org \#3, medium other, high effectiveness). Managers mentioned several different traits they looked for when hiring. These traits are displayed in Table 24.

\begin{tabular}{|l|c|}
\hline \multicolumn{1}{|c|}{ Trait } & $\begin{array}{c}\text { \# of } \\
\text { Organizations } \\
\text { Reporting }\end{array}$ \\
\hline People skills / interpersonal skills & 12 \\
\hline Personality fits in group/organization & 6 \\
\hline Communication skills & 5 \\
\hline Team player & 5 \\
\hline Good aptitude for learning & 4 \\
\hline Good attitude & 4 \\
\hline Motivated & 4 \\
\hline Initiative & 3 \\
\hline Service oriented & 3 \\
\hline Adaptable & 2 \\
\hline Handles pressure/stress & 2 \\
\hline Independent & 2 \\
\hline Requires little to no supervision & 2 \\
\hline Problem solver & 2 \\
\hline Self starter & 2 \\
\hline Aggressive & 1 \\
\hline Commitment & 1 \\
\hline Confidence & 1 \\
\hline Conflict Management Skills & 1 \\
\hline Creative & 1 \\
\hline Doers & 1 \\
\hline
\end{tabular}




\begin{tabular}{|l|l|}
\hline Energetic & 1 \\
\hline Entrepreneur & 1 \\
\hline Fast learner & 1 \\
\hline Fun & 1 \\
\hline Gung-ho & 1 \\
\hline Honesty & 1 \\
\hline Makes effort & 1 \\
\hline New ideas & 1 \\
\hline No fear & 1 \\
\hline Ownership & 1 \\
\hline Patient & 1 \\
\hline PR skills & 1 \\
\hline Reliable & 1 \\
\hline
\end{tabular}

Table 24: Personality Traits

Communication skills were mentioned in five different organizations. It was felt that people skills alone were not sufficient unless paired with the ability to communicate.

"[I] look for a personality that fits in with the organization. People skills. Communication skills. There are people who have good people skills but not good communication skills so it's lost. (Org \#1, small other, medium effectiveness)

The ability to fit in the group or organization was another popular choice with six organizations reporting. One organization mentioned a list of desired personality traits:

"Lack of fear, make effort, have fun, can deal with egos, aware of who you're dealing with and how to deal with them, little room for anger, people skills important, must have confidence in yourself or users won't have you." (Org \#11, small private, high effectiveness)

One organization stated that a person's ability to translate between business and technical terms was a highly regarded skill.

"[I am looking for] somebody that can understand the business and is able to do that translation [into technical terms] because that's a big part of it. Sometimes 
users will have difficulty communicating their requirements so those types of skills, communication skills, are important." (Org \#1, small other, medium effectiveness)

Although managers looked for a mix of education, experience, technical skills, and people skills when hiring, there was no direct relationship between the hiring practices and support effectiveness. These areas are investigated further when examining the support personnel point of view in section 4.6.1. An indirect relationship may be found where the hiring practices influence the type of people hired whose skills/background influenced the computer support effectiveness.

\subsection{Success measurement}

Managers in all participating organizations were asked how they define success in providing the support function. Answers fell into six main focus areas: users, problem/service, technology, project, staff, and IT department.

1. Users

Several managers provided user-related success criteria. One user-related criterion was the support department's ability to understand users' needs, requirements and expectations. Do we know what the users' needs are? Can we fulfill these needs? Are we able to keep up with or ahead of the user requirements? Are we able to meet user expectations? Are users able to perform their job. Some examples of specific user-related success examples are:

"Understanding users' needs. Deliver applications on time with right functionality. Users prepared for new application they get. Post 
implementation: addressing users concerns and problems as soon as possible." (Org \#2, large other, medium effectiveness"

"Bring in applications users need... users involved in development." (Org \# 7 , small other, high effectiveness)

"If I can stay 2 steps ahead of my client requirements whether they know it or not" (Org \#, large government, low effectiveness)

Another user-related success criterion was user involvement. How involved are the users in support and IS-related activities? User satisfaction was another criterion. Are users happy, having fun, and challenged? Are they satisfied with the computer support being provided? One final user-related success criteria was user feedback. Does we receive positive feedback from users? Do we receive no little or negative feedback from users?

2. Problem / Service

The second category of success measurement answers related directly to the problems being logged or the services being provided. One problem related success criteria was learning from experience and avoiding making the same mistakes twice. Quantitative problem measurements were used in some instances (e.g., \# of problems, reduction in \# of problems, \# of high priority problems) as well as time to repair statistics (e.g., downtown, total time to fix problem) and service standards (e.g., meeting agreed-upon service standards). 
3. Technology

The third success measurement category dealt with technology. Is there technological advancement demonstrated in the support and services (e.g., are we implementing new technology, keeping up with technology, "winning with technology")?

"Ability to take on new challenges, identify new processes, tackle new technology and come up a winner." (Org \#11, small private, high effectiveness)

Other criteria included if the technology was stable, reliable, and/or transparent to the users. For example:

"If technology is transparent; never breaks down (Org \#7, small other, high effectiveness)

The final technology-related criteria involved the ability to maximize the technology life cycle.

4. Project

Project-related success criteria ranged from project completion measurements

(e.g., \# of projects completed). For example:

"[Projects are] on time, under budget, per spec." (Org \#6, large government, low effectiveness)

Proactive behaviour was also among the success criteria. Are we able to be proactive instead of always reacting? For example, one organization's goal was:

"Spending less time firefighting, more proactive problem prevention, and more project work." (Org \#10, large private, low effectiveness) 
Goal-oriented criteria were also included. Does the team have the sense of achieving a goal? Are we facing new challenges?

5. Staff

Staff satisfaction was the fifth category of success criteria. Are my staff positive, happy, and have fun? Is morale good? Are people challenged?

"Keeping people positive. Morale is the sole factor in successful support to users." (Org \#2, large other, medium effectiveness)

\section{IT Department}

IT department-related success criteria were the final category. Criteria in this category included if the users understand technology and its usefulness as well as if the IT department has credibility in the organization.

"The key is credibility. Once you [IT] has credibility in the organization, you tend to have less problems because people will recognize that you are supposedly the expert. If don't have, need to earn." (Org \#1, small other, medium effectiveness)

Some success definition trends are displayed in Table 25. The most interesting one involved the use of user-focused success criteria. In three of the four organizations with high effectiveness ratings, the most popular form of determining success was using userrelated criteria. In these same three organizations, all of the interviewed managers reported using some form of user success definition. In the low effectiveness organizations, user-related success criteria were most frequently used only in one of the four organizations. As well, there was never any agreement between managers within a 
single organization with a low effectiveness rating that user-criteria should be used as a measure of success. Low effectiveness organizations tended to focus more on problem and project-focused success criteria.

The following table displays the trends by organization by effectiveness. For example in the first row, 3 of the 4 high effectiveness organization used more user success criteria than other types of success criteria.

\begin{tabular}{|c|c|c|c|}
\hline \multirow{2}{*}{$\begin{array}{l}\text { Focus } \\
\text { Area }\end{array}$} & \multicolumn{3}{|c|}{ Organizational Trends } \\
\hline & High Effectiveness & Medium Effectiveness & Low Effectiveness \\
\hline Users & $\begin{array}{l}\text { - } 3 \text { of 4: User success } \\
\text { criteria had the highest } \\
\% \text { of responses } \\
\text { - } 3 \text { of } 4 \text { : All managers } \\
\text { within a single } \\
\text { organization had user- } \\
\text { focused success } \\
\text { criteria }\end{array}$ & $\begin{array}{l}\text { - } 3 \text { of } 4 \text { : User criteria had } \\
\text { the highest \% of } \\
\text { responses } \\
\text { - } 1 \text { of } 4 \text { : All managers } \\
\text { within a single } \\
\text { organization had user- } \\
\text { focused success criteria }\end{array}$ & $\begin{array}{l}\text { - } 1 \text { of } 4: \text { User criteria } \\
\text { had the highest \% of } \\
\text { responses }\end{array}$ \\
\hline $\begin{array}{l}\text { Problem / } \\
\text { Service }\end{array}$ & $\begin{array}{l}\text { - No organizations } \\
\text { mentioned. }\end{array}$ & $\begin{array}{l}\text { - } 1 \text { of } 4 \text { : Problem-related } \\
\text { criteria had the highest } \\
\% \text { of responses } \\
\text { - } 2 \text { of } 4: \text { All managers } \\
\text { within a single } \\
\text { organization had } \\
\text { problem-focused } \\
\text { success criteria }\end{array}$ & $\begin{array}{l}\text { - } 2 \text { of } 4 \text { : Problem- } \\
\text { related criteria had } \\
\text { the highest } \% \text { of } \\
\text { responses }\end{array}$ \\
\hline Technology & $\begin{array}{l}\text { - } 1 \text { of } 4: \text { Technology } \\
\text { criteria had the highest } \\
\% \text { of responses } \\
\text { - } 1 \text { of } 4: \text { All managers } \\
\text { within a single } \\
\text { organization had } \\
\text { technology-focused } \\
\text { criteria }\end{array}$ & $\begin{array}{l}\text { - } 1 \text { of } 4: \text { Technology } \\
\text { criteria had the highest } \\
\% \text { of responses } \\
\text { - } 1 \text { of } 4: \text { All managers } \\
\text { within a single } \\
\text { organization had } \\
\text { technology-focused } \\
\text { criteria }\end{array}$ & $\begin{array}{l}\text { - } 1 \text { of } 4: \text { Technology } \\
\text { criteria had the } \\
\text { highest } \% \text { of } \\
\text { responses }\end{array}$ \\
\hline Project & $\begin{array}{l}\text { - } 1 \text { of } 4: \text { Project-related } \\
\text { criteria had the highest }\end{array}$ & $\begin{array}{l}\text { - No organizations } \\
\text { mentioned. }\end{array}$ & $\begin{array}{l}\text { - } 2 \text { of 4: Project-related } \\
\text { criteria had the }\end{array}$ \\
\hline
\end{tabular}




\begin{tabular}{|c|c|c|c|}
\hline \multirow{2}{*}{$\begin{array}{l}\text { Focus } \\
\text { Area }\end{array}$} & \multicolumn{3}{|c|}{ Organizational Trends } \\
\hline & High Effectiveness & Medium Effectiveness & Low Effectiveness \\
\hline & $\begin{array}{l}\text { \% of responses } \\
1 \text { of } 4: \text { All managers } \\
\text { within a single } \\
\text { organization had } \\
\text { project-focused criteria }\end{array}$ & & $\begin{array}{l}\text { highest \% of } \\
\text { responses }\end{array}$ \\
\hline Staff & $\begin{array}{l}\text { No organizations } \\
\text { mentioned. }\end{array}$ & $\begin{array}{l}1 \text { of } 4: \text { Staff-related } \\
\text { criteria had the highest } \\
\% \text { of responses }\end{array}$ & $\begin{array}{l}\text { No organizations } \\
\text { mentioned. }\end{array}$ \\
\hline $\begin{array}{l}\text { IT } \\
\text { department }\end{array}$ & $\begin{array}{l}0 \text { of } 4: \text { IT department- } \\
\text { related criteria had the } \\
\text { highest } \% \text { of responses }\end{array}$ & $\begin{array}{l}0 \text { of } 4: \text { TT department- } \\
\text { related criteria had the } \\
\text { highest } \% \text { of responses }\end{array}$ & $\begin{array}{l}\text { - } 0 \text { of } 4: \text { IT department- } \\
\text { related criteria had } \\
\text { the highest \% of } \\
\text { responses }\end{array}$ \\
\hline
\end{tabular}

Table 25: Success Focus Areas

Based on the fact that user-related success criteria were most frequently used in high and medium effectiveness organizations, it is hypothesized that organizations that use user-related success criteria to evaluate their performance provide a higher level of support effectiveness. The more managers in the organization that share this view, the higher the effectiveness. Organizations should ensure their support managers work together to define standard success criteria and implement ways to measure against this criteria. Buy-in must be obtained from all of the support managers. Success criteria should include user-related success factors related, such as: (1) User needs, requirements, expectations; (2) User involvement; (3) User satisfaction; and (4) User feedback.

Managers were asked how they monitor problems in their organization.

"[One past problem is that department] didn't have good performance measures in place. There were implicit processes: people knew how to do them but no book to follow. [To solve:] initiative to put more explicit processes in place and make 
measures of performance and reporting performance against those measures." (Manager, org \# 10, large private, low effectiveness)

Nine of the twelve participating organizations used problem-tracking software. One organization (Manager, org \# 7, small other, high effectiveness) implemented 'Help Desk' problem tracking software because, in the past, they couldn't keep track of problems and inventory. In the three remaining organization $\mathrm{s}^{23}$, they used a combination of informal ways of recording problems (database, hotline account), message / solution posting, and word of mouth. Other reported monitoring devices are outlined below in Table 26.

\begin{tabular}{|c|c|c|c|c|}
\hline Comments & $\begin{array}{c}\text { \# of } \\
\text { Organizations }^{24}\end{array}$ & Size & Type & Effectiveness \\
\hline Automated statistics & 5 & $\begin{array}{l}1 \text { Small } \\
2 \text { Medium } \\
2 \text { Large }\end{array}$ & $\begin{array}{l}1 \text { Other } \\
3 \text { Government } \\
1 \text { Private }\end{array}$ & $\begin{array}{l}2 \text { High } \\
1 \text { Medium } \\
2 \text { Low }\end{array}$ \\
\hline Weekly / monthly reports & 3 & $\begin{array}{l}1 \text { Medium } \\
2 \text { Large }\end{array}$ & $\begin{array}{l}1 \text { Other } \\
1 \text { Government } \\
1 \text { Private }\end{array}$ & $\begin{array}{l}1 \text { High } \\
2 \text { Low }\end{array}$ \\
\hline Trend analysis & 1 & 1 Large & 1 Other & 1 Medium \\
\hline Manual statistics & 1 & 1 Medium & 1 Government & 1 Medium \\
\hline By "feel of things" & 1 & 1 Medium & 1 Government & 1 Medium \\
\hline Response times & 1 & 1 Medium & 1 Government & 1 High \\
\hline
\end{tabular}

Table 26: Problem Monitoring Comments

\footnotetext{
${ }^{23}$ One small other, one small private, one medium private

${ }^{24}$ Not mutually exclusive
} 
There did not appear to be a relationship between problem monitoring methods and organizational effectiveness. Based on the results, some questions applicable to future research in this area include:

- Does your support department perform callbacks to help gauge user satisfaction?

- How are problems tracked for new enhancements (e.g., during project rollout phase)?

\subsection{Direction}

When managers were asked how they thought the IS department would change in the next five to ten years, the responses were in the following areas:

- Technology

- Organizational structure

- Support role

- Support people

Nine of the twelve organizations reported how they thought technology would change. Common terms used to describe the technology changes in the future were "complex", "complicated", "continually changing", and just plain "more".

Some notable quotes from managers include:

"Supporting more people working at home and remote functions, accessing all systems over Internet, imaging workflow. " (Org \#3, medium other, high effectiveness) 
"[Move to completely] networked computers. Think users will be forced to keep static and users will no longer be able to change their configuration." (Org \#5, medium government, medium effectiveness)

"Automation in IT processes, increase in the level at which we develop software; fast pace in technology; need to be more procedural, structured, keep better records, a knowledge base". (Org \#8, medium government, medium effectiveness)

Nine of the organizations reported that there would be changes in the organizational structure. Outsourcing was the most common trend as mentioned by six organizations. Two organizations were not sure if they would exist in five years. One of these organizations had a high effectiveness rating (other) while the other had a low effectiveness rating (private).

"More money invested in technology to do more with less (standardization, downsizing user community, replacing users with technology)". "Go to contracts and outsourcing." (Org \#8, medium government, medium effectiveness)

Some managers felt that centralization would end and some felt that more centralization would occur. There would be the need to support both home and remote users effectively. One manager felt that technology would have an increased importance in the organization.

"Technology will be intrinsic part or organization. The $\mathrm{CIO}$ will be incorporated in the CEO" (Org \#3, medium other, high effectiveness)

There was consensus that the support role would always be required though there were some differing opinions on how it would change. Managers from three organizations felt that end user development (via contracting or off-the-shelf products) was the future with IT providing consulting, training, and support. 
"Might become brokers with just core staff to coordinate and contract everything. [This is] good because you can pick and choose skills but bad because skills not always available." (Org \#9, medium government, high effectiveness)

"Computing will be done by end users directly or end users will hire someone else to do it. IT will change to a consulting and training role and a very core development. The core would be fundamental corporate business (and rare). My view of IT is going to be crisp, lean - we should consult, train, help users develop systems, and help them access corporate data. Yes, we need another group (that can be outsourced) to develop very core applications. Help desk would be outsourced for generic products and support." (Org \#2, large other, medium effectiveness)

Two organizations believed more interactive and sophisticated support tools would be created/used. As technology changes and grows, there will be a need for more support than in the past (reported by two organizations)

"Unpredictable. Support function will grow in future, users still intimidated by systems; More support because more functionality." (Org \#4, large government, low effectiveness)

In the final category, managers in six of the twelve organizations reported that there would be changes in the type of support people required. There was some disagreement if people would need to be generalists or specialists:

"Move from generalists to specialists as tech becomes more complicated." (Org \#6, large government, low effectiveness)

"Move from specialist to generalist in sets of technology. Technology sets will be outsourced. Work and objectives will be refined on a continual basis (no job descriptions); contractual nature of jobs." (Org \#10, large private, low effectiveness)

The need for people who can continuously learn was mentioned by two organizations, as was the future need for more systems analysts as opposed to programmers.

"The skill requirement of people will change. In smaller shops, you're going to see the end of central IS development. End user development is the way to go with 
IS supporting their de: : lopment. The skill of support is the type of person that has a good knowledge of the tools and grasps the business requirements. Infrastructure and architecture will get to the point where there are less highly skilled technical people required to support those environments. IT people are going to IT research where they are building support tools and don't have to support users." "The majority of applications will be off-the-shelf purchases which could mean a different type of people required (need analysts more than programmers)." (Org \#1, small other, medium effectiveness)

In all of these different visions for the future, there was no relationship found between the type of vision and the current effectiveness of the support function in their organization.

\subsection{Competence}

The competence of the management of the support function and its relationship to computer support effectiveness was examined. Competence was measured by the number of perceived management issues reported by the support personnel. Support personnel were asked if there were any issues with the current management of their groups. In four of the twelve participating organizations, support personnel only had positive things to say about their managers. These organizations primarily had high effectiveness ratings and were an "other" company type. The remainder of the organization had one or more reports of poor management. The breakdown of the ratings for managerial competence (from the support personnel opinion) is displayed in Table 27. 


\begin{tabular}{|l|c|l|l|l|}
\hline $\begin{array}{c}\text { Support Personnel } \\
\text { Reports of Good vs. Bad } \\
\text { Management }\end{array}$ & \multicolumn{1}{|c|}{$\begin{array}{c}\text { \# of } \\
\text { Organizations }\end{array}$} & \multicolumn{1}{|c|}{ Sype } & Effectiveness \\
\hline All good & 4 & $\begin{array}{l}2 \text { small } \\
1 \text { medium } \\
1 \text { large }\end{array}$ & $\begin{array}{l}3 \text { other } \\
1 \text { private }\end{array}$ & $\begin{array}{l}3 \text { high } \\
1 \text { medium }\end{array}$ \\
\hline 1 bad report & 6 & $\begin{array}{l}1 \text { small } \\
2 \text { medium } \\
3 \text { large }\end{array}$ & $\begin{array}{l}1 \text { other } \\
3 \text { government } \\
2 \text { private }\end{array}$ & $\begin{array}{l}1 \text { high } \\
2 \text { medium } \\
3 \text { low }\end{array}$ \\
\hline$>1$ bad reports & & $\begin{array}{l}1 \text { medium } \\
1 \text { large }\end{array}$ & 2 government & $\begin{array}{l}1 \text { medium } \\
1 \text { low }\end{array}$ \\
\hline
\end{tabular}

\section{Table 27: Reports of Good / Bad Management}

In two of the organization that did not receive any negative management comments from support personnel, a few managers had comments on why they thought they were successful ${ }^{26}$. One organization reported the fact that strong leadership and the ability to support their staff's decisions was key.

"Our director is open-minded. [We deal with] difficult users every so often so key is having a director to back you up. [There is a] need for a strong CIO to make sure on same agenda." (Manager, org \#3, medium other, high effectiveness)

Another organization had experienced problems with bad management where autocratic decisions were made without the involvement of the support team. Good results started only with a change in management who asked for the support team's opinions and also had a good understanding of the benefits of technology.

${ }^{25}$ Mutually exclusive

${ }^{26}$ Please note that at the time, the managers were not aware of how their support personnel evaluated them. 
"We were forced to implement certain software [due to upper management decision). No requirements analysis is done; poor management." "[Success was] only achieved when change in senior management. [The new] Management was aware of value of technology and [we] moved ahead [with a technology renewal]." (Managers, org \# 7, small other, high effectiveness)

In organizations that had at least one report of bad management from the support staff, one of the main themes was the lack of understanding management had of either technology, the IT role, and/or the complexity of the support personnel's tasks. One organization reported that:

"[It is] difficult for [management] to understand technology. In my opinion, it's almost impossible for a manager to truly understand the technology if he is certain generations or levels away from the practitioner end. It is a mixed bag [concerning whether management supports what I do] - 50-50." (Support, org \#1, small other, medium effectiveness)

A manager from the same organization recognized the need for credibility with the support staff on technical areas.

"Managing technical people is difficult at the best of times but you have to have a certain amount of credibility with staff because if they don't think you have the technical skills, they're going to try to snow you every chance they get...The single biggest thing [to help situation] is to give them interesting work and opportunities." (Manager, org \#1, small other, medium effectiveness)

Other comments in the area of technology understanding include:

"Management doesn't understand what you're going through." (Support, org \#9, medium government, high effectiveness)

"Need to have management that knows complexity of tasks." (Support, org \#10, large private, low effectiveness)

"There is a management problem. Technically capable people don't rise into management, they don't understand how to do long term maintenance, department is product/project oriented and not maintenance oriented. Managers are 
interchangeable but don't understand that technical people aren't (e.g., HTML programmer->Excel). Management is motivated by different things (politics). They have better management now but they do not have technical skills and will not have understanding. (Support, org \#8, medium government, medium effectiveness)

"Management has a lack of understanding of unique IT role." (Support, org \#12, large private, low effectiveness)

Support personnel want a manager who can understand the job they perform and its complexity. They may feel that without an understanding of the technology, how can a manager properly help them do their job (e.g., prioritizing tasks, provide time schedules with reasonable deadlines). Support personnel in two organizations also mentioned politics as an issue. In both cases, management shared this opinion.

"Very often see decisions are made that are based on politics or on a management view but then sometimes that is the overwhelming factor and I have to accept it." (Support, org \#1, small other, medium effectiveness) "Politics/\%\&\$ from upper management [a problem] (dealing with different personalities, different turfs)" (Manager, org \#1, small other, medium effectiveness)

"Management motivated by different things (politics) [than technical people]." (Support, org \#8, medium government, medium effectiveness) "Politics killing the place." (Manager, org \#8, medium government, medium effectiveness)

"[Problems with] politics, territorial issues." (Support personnel, org \#2, large other, medium effectiveness)

Another prime theme in support issues with management competence revolved around management's ability to take care of their employees, treat them fairly, and provide continuity and support.

"[Management is] too controlling. [He] lacks people and management skills [resulting in a] lack of independence for employees." (Support, org \#5, medium government, medium effectiveness) 
"No support from management. [He is] not doing managerial tasks. He is in other location. [There is a] lack of a good manager. ... We have changed managers four times in last two years." (Support, org \#10, large private, low effectiveness)

"Management thinks about efficiency but not employee's salary, benefits, well being. ... Management support was zero but now starting to come with new VP." (Support, org \#12, large private, low effectiveness)

"[There is a] management problem with the supervisor... There is a lack of good management: doesn't have one vision, group run badly, does not recognize education, favors people from one side of merge, does not enforce documentation, one person deciding philosophy - other group has no say, not coordinated, [our group is the] underdog (like poor children of family)." (Support, org \#6, large government, low effectiveness)

Support personnel as well as management in one organization reported

inconsistent messages as a communication-related issue

"[Management has been] pretty good over the years. I am undecided about new management. They give a different message each day (be nice, be firm, kick ass)." (Support, org \#4, large government, low effectiveness) "Too much talking, too many meetings, not quick." (Manager, org \#4, large government, low effectiveness)

Some managers provided feedback on what some of their challenges were as well

as how they had fixed some problems in the past.

"The [support] group was very demoralized with past management and users had a low opinion of area. [To correct this used] leading by example and getting some success stories." (Manager, org \#1, small other, medium effectiveness)

"[Past problems included] staffing complement: no full time manager in a long time, help desk bounced around between managers, low morale, no faith in management. [Solved by] putting proper structure in place, documented process and procedures, stabilized department. Result = better morale." (Manager, org \# 12 , large private, low effectiveness) 
Organizations where support personnel reported only good things about their managers were all high or medium effectiveness. Based on this, it is hypothesized that a direct positive relationship between management competence and support effectiveness exists. Managers need to display strong leadership skills. They need to define and communicate the expected role and responsibilities and have a good understanding of the job's complexity to set realistic targets. Managers need to assist their staff, if required, to meet these targets. They need to listen to their staff and help look out for the individual and team's best interests. Without this, there would be a reduced incentive for support personnel to perform. A manager's ability to help prioritize their staff's work and set realistic expectations with the users and upper management is very important to ensure that their support personnel do not get overwhelmed or overworked.

\subsection{Communication}

Managers were asked to comment on the communication between upper management in their organizations and the IT department. Based on the comments, the organizations were categorized into whether communication was good, had some issues, or was a definite problem. Please refer to Table 28 for the breakdown of the upper management-IT communication ratings by organization. 


\begin{tabular}{|l|c|l|l|l|}
\hline \multicolumn{1}{|c|}{ Communication } & \multicolumn{1}{|c|}{$\begin{array}{c}\text { \# of } \\
\text { Organizations }^{27}\end{array}$} & \multicolumn{1}{|c|}{ Size } & Type & Effectiveness \\
\hline Good & 4 & $\begin{array}{l}2 \text { small } \\
2 \text { medium }\end{array}$ & $\begin{array}{l}2 \text { other } \\
1 \text { government } \\
\text { private }\end{array}$ & 4 high \\
\hline Some Issues & 7 & $\begin{array}{l}1 \text { small } \\
2 \text { medium } \\
4 \text { large }\end{array}$ & $\begin{array}{l}1 \text { other } \\
4 \text { government } \\
2 \text { private }\end{array}$ & $\begin{array}{l}3 \text { medium } \\
4 \text { low }\end{array}$ \\
\hline Definite Problem & & 1 large & 1 other & 1 medium \\
\hline
\end{tabular}

Table 28: Communication between Upper Management and IT

The most common issue (reported by five organizations) was that upper management did not have a good understanding of IT issues and it was difficult to justify IT-related problems to them.

"Most of senior management understands that technology is a way of achieving things. Would be nice if they had better appreciation for what technology can do. Varies depending on who's in top echelon. Currently not much communication. [Top management feels] "IT is an necessary evil" in terms that it costs a lot but you can't get along without it but should cost less." (Manager, org \#2, large other, medium effectiveness)

"It is hard getting management to focus on important issues; haven't seemed to get feelings across to management successfully." (Manager, org \#4, large government, low effectiveness)

Other reported issues included not having a lot of formal channels, no strong voice at senior management, and unrealistic expectations.

"[Upper management] wants more done then is possible". (Manager, org \#5, medium government, medium effectiveness)

${ }^{27}$ Mutually exclusive 
Two patterns emerged when examining the upper management-IT communication ratings: size and effectiveness. All large organizations reported at least some issues with communication whereas small companies tended to have good communication. Managers in small companies stated their size helped because there were few layers and everyone knew everyone breaking down a lot of barriers. Also, all high effectiveness organizations ranked their communication as good whereas no low effectiveness organization achieved this rank. It is hypothesized that there is a direct link between this type of communication and support effectiveness.

One medium-sized organization with a good communication rating describes their success due to an effective CIO:

"Good lines [of communication] are helped because of CIO and positioned well in structure." (Manager, org \#3, medium other, high effectiveness)

A direct relationship was found between upper management-IT communication and computer support effectiveness. To try and improve communication in this area, a highranking IT representative is required to be able to champion the IT causes. IT requirements must be put in the form of business cases where the technical needs link back to direct business gains (e.g., cost reduction, revenue generation, higher productivity). IT must be able to sell these benefits to upper management as well as provide reasonable expectations on when these gains would be realized along with how they can be measured. The business benefits presented to upper management must link to 
technical implementation plans with measurable milestones so progress and success can be reported and understood by both IT and upper management.

IT staff must be educated on the link between technology and business to understand that if there are no business benefits to be gained from a proposed technology change that it is hard to obtain management approval. Sometimes the ultimate technological implementation is not required when a cheaper, middle of the road implementation may meet the business needs.

Both managers and support personnel were asked to describe the communication that existed between the IS Departments. This communication was categorized and displayed in Table 29.

\begin{tabular}{|l|c|l|l|l|}
\hline \multicolumn{1}{|c|}{ Communication } & \multicolumn{1}{|c|}{$\begin{array}{c}\text { \# of } \\
\text { Organizations }^{28}\end{array}$} & \multicolumn{1}{|c|}{ Size } & \multicolumn{1}{c|}{ Type } & Effectiveness \\
\hline Good & 3 & $\begin{array}{l}2 \text { small } \\
1 \text { medium }\end{array}$ & $\begin{array}{l}1 \text { other } \\
1 \text { government } \\
1 \text { private }\end{array}$ & $\begin{array}{l}2 \text { high } \\
1 \text { medium }\end{array}$ \\
\hline Some Issues & 7 & $\begin{array}{l}1 \text { small } \\
3 \text { medium } \\
3 \text { large }\end{array}$ & $\begin{array}{l}3 \text { other } \\
\text { government } \\
1 \text { private }\end{array}$ & $\begin{array}{l}\text { 2 high } \\
3 \text { medium } \\
2 \text { low }\end{array}$ \\
\hline Definite Problem & 2 large & $\begin{array}{l}1 \text { government } \\
\text { 1 private }\end{array}$ & 2 low \\
\hline
\end{tabular}

Table 29: Communication between IS Departments

The main theme in communication issues between IS departments was the "themus" attitude. This took different forms. There were reports that lack of consultation

${ }^{28}$ Mutually exclusive 
between departments lead to the feeling that one group getting stuck with the problems caused by another group.

"Left hand doesn't talk to right hand. [Problem with] coordination within IS." (Support personnel, org \#10, large private, low effectiveness)

"Communication not great. It is not a cooperative culture. There is a fair amount of infighting: them-us". (Manager, org \#10, large private, low effectiveness)

"Think it [communication between departments] is getting better. There was a general feeling that they [application development group] were developing their systems in total isolation not consulting with us when we were on the supporting end. And I think this is changing for the positive right now. We felt we were on the brunt end of the support, "you develop this and we end up with the mess'." (Support personnel, org \#2, medium other, low effectiveness)

"Trying to get support from other groups for 3rd level support -that's probably the biggest thing [problem]." (Support personnel, org \#2, large other, medium effectiveness)

The "them-us" attitude also took the form of the lack of consistent messages to the user

community (i.e., one group saying one thing, another group saying something else).

"There are opportunities for interdepartmental communications. Not much, some between regions. Trying to bridge gap. Next area to look at: Improve proper communication in service organization. When $I$ tell the user $\mathrm{x}$ is going to happen but another part of service doesn't understand and tells the user something else, the users say hey wait a minute" (Manager, org \#4, large government, low effectiveness)

Trying to solve "them-us" issues is not without its challenges due to the competitiveness and between groups.

"[Communication between IS departments is] getting better. We haven't always had best communication. Now with us all reporting to the same director, we have these meetings. ... Sometimes it's difficult to get everyone's opinion without ratting the other group. I think that's the biggest problem we have. The groups 
still sometimes feel threatened." (Support personnel, org \#1, small other, medium effectiveness)

Only low effectiveness organizations reported definite problems with communication in this area with only high and medium organization reporting good communication. It is hypothesized that communication between IS departments has a direct relationship to support effectiveness.

Due to the large impact communication between IS departments had on the effectiveness of the support function, organizations should place priority on trying to correct problems they are having in this area. Required corrective measures should be pursued in organizations in instilling a cooperative team environment between $\mathrm{TT}$ departments to eliminate "blame game" and "pass the buck" situations and ensure that the users receive consistent messages from all parts of the IS organization. Departmental goals, role definitions, and interdepartmental dependencies must be defined and communicated between the groups. Personnel in one department need to understand how their job impacts others and vice versa as well as the overall impact on the service provided to the users. Performance criteria (and resulting benefits) should be linked, in part, to success of the overall IS department ensuring that people have something tangible to gain from a cooperative working environment.

\subsubsection{Summary of Management Practices Hypotheses}

The following hypotheses were proposed regarding management practices and computer support effectiveness. Hypotheses tagged 'NEW' were not validated based on 
the study's data but were evaluated to be worth further study based on a combination of interview comments and past research.

1. Unfair distribution of resources between the application and support components of the IS department lead to decreased support effectiveness.

2. Organizations that use user-related success criteria to evaluate their performance provide a higher level of support effectiveness. The more managers in the organization that share this view, the higher the effectiveness.

3. Competent support managers lead to effective support functions.

4. Large organizations have more issues with communication than smaller organizations.

5. There is a positive relationship between the quality of the communication between the IS department and senior management and the effectiveness of the support function.

6. There is a positive relationship between the quality of the communication between individual IS departments and the effectiveness of the support function.

7. NEW: The level of proactive support relates positively to the effectiveness of the support function.

8. NEW: Technology standards, user involvement, system monitoring, and preventative maintenance are effective forms of proactive support.

9. NEW: The use of technology standards reduces the amount and difficulty of support required. 
10. NEW: The more restrictive the standards, the less support required.

11. NEW: The more restrictive the standards, the lower the user satisfaction of advanced users.

12. NEW: If the standards provide technology that meets user's expectations and needs, the use of standards has a positive relationship with support effectiveness.

\subsection{Computer Support Personnel}

\subsubsection{Discussion}

Various attributes and attitudes of the computer support personnel who provided the services to the users were investigated to look at possible relationships with the effectiveness of the support function to investigate the following question:

Research Question \#4: What computer support personnel attitudes / practices influence the effectiveness of the computer support function?

The following areas were examined:

- Personality type

- Experience / training / education

- Opinion of end users

- View of role as support personnel

- Turnover, advancement, morale, stress level, job satisfaction, motivation, commitment

- Communication 


\subsubsection{Personality type}

The average age of support personnel in all organizations ranged from 25 to 35 . The breakdown is displayed in Table 30 . A relationship between age and support effectiveness was not found. Private organizations tended to have younger support staff than government and other organizations. The following table displays the categorization of organizations by the approximate average age of their support personnel.

\begin{tabular}{|c|l|l|l|l|}
\hline $\begin{array}{c}\text { Approximate Average } \\
\text { Age of Support Personnel }\end{array}$ & \multicolumn{1}{|c|}{$\begin{array}{c}\text { \# of } \\
\text { Organizations }\end{array}$} & \multicolumn{1}{|c|}{ Size } & \multicolumn{1}{|c|}{ Type } & Effectiveness \\
\hline 25 & 4 & $\begin{array}{l}2 \text { small } \\
2 \text { large }\end{array}$ & $\begin{array}{l}1 \text { other } \\
3 \text { private }\end{array}$ & $\begin{array}{l}1 \text { high } \\
1 \text { medium } \\
2 \text { low }\end{array}$ \\
\hline 30 & 4 & $\begin{array}{l}2 \text { medium } \\
2 \text { large }\end{array}$ & $\begin{array}{l}\text { 1 other } \\
3 \text { government }\end{array}$ & $\begin{array}{l}1 \text { high } \\
2 \text { medium } \\
1 \text { low }\end{array}$ \\
\hline 35 & 4 & $\begin{array}{l}1 \text { small } \\
2 \text { medium } \\
1 \text { large }\end{array}$ & $\begin{array}{l}2 \text { other } \\
\text { 2 government }\end{array}$ & $\begin{array}{l}\text { 2 high } \\
1 \text { medium } \\
1 \text { low }\end{array}$ \\
\hline
\end{tabular}

Table 30: Average Support Personnel Age

It was proposed that support personnel who were outgoing and user-focused provided more effective service. In nine of twelve organizations, all support personnel interviewed responded that people skills were important to their work. Support personnel in the remaining three organizations with the exception of one dissenting support personnel in each company also reported the importance of people skills. One dissenter

\footnotetext{
${ }^{29}$ Mutually exclusive
} 
said "[People skills] not as important as technical ski!:s, just fix it." (Support personnel, org \#11, small private, high effectiveness)

The organizations with one dissenter were small or medium and had a medium or high effectiveness rating. No organizations had more than one dissenter who believed that people skills were not important. One interesting note that while both support personnel and management agreed on their importance (see section 4.5.1.2.3), people still feel that these skills are overlooked ${ }^{30} .33 \%$ of all people interviewed had taken at least one course on interpersonal skills.

Based on the interview questions, there was insufficient data to evaluate how good support personnel's people skills were in dealing with the users. It would be useful in future studies to include some form of measure (e.g., personnel reviews, user feedback) to gauge the relationship between people skills and support effectiveness.

Support personnel provided comments on the importance of people skills due to their close contact with the end users and the variety of end users that require support. The ability to create a first impression was paramount.

"Client has to have a good opinion of the support personnel, it is very important." "60-75\% of necessary skill set. First and last five minutes important and can make or break call." (Support personnel, org \#4, large government, low effectiveness)

"There are some reports from users of support people with the attitude 'you're too stupid to understand so let me be and I'll fix it'... You [a support person] can ask

\footnotetext{
${ }^{30}$ Report by support personnel, org \#6, large government, low effectiveness
} 
user if they rebooted, they say yes, and then you reboct anyway. It is really important to understand your audience. I'd like to get the dispatcher type of thing in place to eliminate that sort of first impression." (Manager, org \#1, small other, medium effectiveness)

There were several comments on the importance of people skills over technical skills as the latter is easier to teach.

"I'll take the people skills over the technical skills any day of the week. You can teach the technical skills. You can not teach the people skills." (Support personnel, org \#2, large other, medium effectiveness)

Although a people skill rating could not be done in this study, support personnel identified specific people skills that were necessary to provide better support. One of these skills was the ability to put and keep users in a receptive frame of mind when trying to solve their problem.

"You have to first deal with [the user] and then their problem. You need to put [the user] in a receptive mode so they hear what you say to remember how to fix it [themselves] the next time." (Support personnel, org \#5, medium government, medium effectiveness)

"You have to maintain professionalism and remain calm ... You have to be able to calm people's fears and give them confidence." (Support personnel, org \#6, large government, low effectiveness)

"The last thing you want to do is frustrate the user and if they have a request or demand that you know you can't possibly give them, you have to be really delicate... It may be great what you do but if you are arrogant or rude then they won't want to deal with you. They'll try and ask for other people. And we're such a small place that everyone knows one another, you build on whatever relationships you have. You sometimes have to put your egos aside." (Support personnel, org \#1, small other, medium effectiveness)

"[You're] dealing with people under pressure and calming them down." (Support personnel, org $\# 9$, medium government, high effectiveness) 
Another important people skill identified was the ability to translate between user language and technical language.

"You have to understand [user's] needs and be able to translate users needs to technical terms." "[You have to] understand users expectations and bridge gap" (Support personnel, org \#12, large private, low effectiveness)

"You, have to talk [users] through the technical and look at their stress level." (Support personnel, org \#9, medium government, high effectiveness)

"I've been told that I have the ability to translate the technical side of things into a more user-friendly type of message that goes a long way. So you have to have that technical knowledge." (Support personnel, org \#2, large other, medium effectiveness)

Another important skill is the ability to try and eliminate the technical stereotype that users may have.

"People perceive the technical services people as a bunch of techno geeks that can't deal with human beings. It's not true but to some extent, you're dealing with a machine. It's a matter of sitting down with users and spending an extra five minutes to explain resolutions." "The IS person has to demonstrate a high level of interpersonal skills. You're going into their area. You're often coming with a certain image ("techie", "IS guy", "speaks a different language"). Whole process involves a considerable amount of change on the part of the users. It is a stressful time because of the change. They're used to doing things a certain way and we're coming and telling them that they have to do things differently. And it very easily gets into confrontational situations. You really have to know how to deal with people to present things in a way that they won't feel threatened. Try and get them to participate actively." (Support personnel, org \#1, small other, medium effectiveness)

Although computer support is often seen as a technical area, due to its service orientation, people skills are as important and sometimes more important than technical skills in providing effective computer support. Although it was not possible to obtain an evaluation of the level of people skills in the computer support organization from this 
study, based on the comments provided by managers and support personnel, a possible hypothesis for future research is that support personnel with good people skills and the ability to translate technical to/from business language provide effective computer support. Managers should place emphasis on hiring support personnel with strong people skills and educating staff on the business side of their users' jobs so they can communicate more effectively with the users and also have a better understanding of the business impact of a problem that is occurring.

\subsubsection{Education}

Support personnel were asked about their educational background. Educational backgrounds ranged from computer science, business, math, and some other. There was a mixture of backgrounds in each organization. On the topic of what education level did the support personnel have, most of the organizations had staff with a mixture of college and university degrees. Please refer to the breakdown of educational level of the support staff by organization and effectiveness in Table 31 . There did not appear to be any relationship between education level (i.e., college versus university emphasis) and the effectiveness of the computer support function. 


\begin{tabular}{|c|c|c|c|c|}
\hline Educational Level & $\begin{array}{c}\text { \# of } \\
\text { Organizations }^{31} \\
\end{array}$ & Size & Type & Effectiveness \\
\hline All university & $\begin{array}{c}1 \\
\text { (org \# 11) }\end{array}$ & 1 small & 1 private & 1 high \\
\hline All college & $\begin{array}{c}1 \\
(\operatorname{org} \# 4) \\
\end{array}$ & 1 large & 1 government & 1 low \\
\hline Primarily university & $\begin{array}{c}1 \\
\text { (org \# 5) }\end{array}$ & 1 medium & 1 government & 1 medium \\
\hline Primarily college & $\begin{array}{c}4 \\
\text { (org \# 3, 8, 9, 12) }\end{array}$ & $\begin{array}{l}3 \text { medium } \\
1 \text { large }\end{array}$ & $\begin{array}{l}2 \text { government } \\
\text { lother } \\
1 \text { private }\end{array}$ & $\begin{array}{l}2 \text { high } \\
1 \text { medium } \\
1 \text { low }\end{array}$ \\
\hline $\begin{array}{c}\text { Even mix between college } \\
\text { and university }\end{array}$ & $\stackrel{4}{(\operatorname{org} \# 1,2,6,10)}$ & $\begin{array}{l}1 \text { small, } \\
3 \text { large }\end{array}$ & $\begin{array}{l}1 \text { government } \\
2 \text { other } \\
1 \text { private }\end{array}$ & $\begin{array}{l}2 \text { medium } \\
2 \text { low }\end{array}$ \\
\hline No answer provided & $\begin{array}{c}1 \\
\text { (org \# 7) }\end{array}$ & 1 small & 1 other & 1 high \\
\hline
\end{tabular}

Table 31: Educational Background

\subsubsection{Experience}

Computer support personnel were asked how many years they worked in an IS department performing computer support or other related work. The average of the support personnel interviewed was calculated for each organization. The average years of experience ranged from 2 to 20 years with an overall average of 10 years. The organizations were categorized by average IS experience. Please refer to Table 32 for a breakdown of years of experience by number of organizations and effectiveness..

${ }^{31}$ Mutually exclusive 


\begin{tabular}{|c|c|l|l|l|}
\hline Average IS Experience & \multicolumn{1}{|c|}{$\begin{array}{c}\text { \# of } \\
\text { Organizations }\end{array}$} & \multicolumn{1}{|c|}{ Size } & Effectiveness \\
\hline $1-5$ years & 3 & $\begin{array}{l}1 \text { small } \\
1 \text { medium } \\
1 \text { large }\end{array}$ & $\begin{array}{l}2 \text { other } \\
1 \text { private }\end{array}$ & $\begin{array}{l}2 \text { high } \\
1 \text { low }\end{array}$ \\
\hline $6-10$ years & 4 & $\begin{array}{l}2 \text { small } \\
2 \text { large }\end{array}$ & $\begin{array}{l}1 \text { other } \\
2 \text { government } \\
1 \text { private }\end{array}$ & $\begin{array}{l}1 \text { high } \\
1 \text { medium } \\
2 \text { low }\end{array}$ \\
\hline $11-15$ years & 3 & 3 medium & 3 government & $\begin{array}{l}1 \text { high } \\
1 \text { medium }\end{array}$ \\
\hline$>15$ years & 2 & 2 large & $\begin{array}{l}1 \text { other } \\
1 \text { private }\end{array}$ & $\begin{array}{l}1 \text { medium } \\
1 \text { low }\end{array}$ \\
\hline
\end{tabular}

Table 32: Average IS Experience of Interviewed Support Personnel

There did not appear to be a direct relationship between experience and effectiveness of the support function. It was expected that the more experienced the computer support personnel, the more effective the provided support. Interviewees noted the importance that experience plays in their ability to provide good support.

"[Support department receives] complaints concerning [users] not getting through on help line then [the help desk] not resolving a lot on the phone because experienced people doing [on-site] visits ... [We are solving problem by putting] increased staff on phones and matching people with skills with people without." (Manager, org \#6, large government, low effectiveness)

"Historically, the help desk had bad reputation and still does a bit. We have to get away from dispatches and have people with trouble shooting skills [on the help desk]" (Manager, org \#10, large private, low effectiveness)

This positive relationship between experience and effectiveness was not found in the participating organizations as two highly effective organizations had an average of 1 to 5

${ }^{32}$ Mutually exclusive 
years experience. Conversely, there was a low effective organization that an average of greater than 15 years experience. This may be explained due to the fast pace of technological change where newer staff may have more recent education on the latest technologies whereas more experienced staff may not have received the required training to keep up to date.

"Technical skills in government are hard to keep up... [why they do a lot of contracting]" (Manager, org \#9, medium government, high effectiveness)

"With the reorganization [in the organization], we need wide range of skills sets. We have tried to solve by rotating 1 st and 2 nd level support and treating them as one team.... Have separate management and 2 nd level technical support. There is now a technical stream." (Manager, org \#10, large private, low effectiveness)

Other possibilities why there is no relationship could be that newer staff is trying to prove themselves. They may not mind the longer hours when they are just starting and may also have a fresh attitude since the work is new and exciting. Since there was no negative relationship found between experience and effectiveness, these factors could be very dependent on the individuals involved. The relationship of training, job satisfaction, and morale to effectiveness are examined in the following sections.

\subsubsection{Training}

Both managers and support personnel were asked how much training support personnel received and if it was sufficient. Table 33 displays the breakdown of the training sufficiency ratings. 


\begin{tabular}{|l|c|l|l|l|}
\hline \multicolumn{1}{|c|}{$\begin{array}{c}\text { Support Personnel } \\
\text { Training }\end{array}$} & $\begin{array}{c}\text { \# of } \\
\text { Organizations }\end{array}$ & \multicolumn{1}{|c|}{ Size } & \multicolumn{1}{|c|}{ Type } & Effectiveness \\
\hline Good / Sufficient & 5 & $\begin{array}{l}2 \text { small } \\
1 \text { medium } \\
2 \text { large }\end{array}$ & $\begin{array}{l}1 \text { government } \\
2 \text { other } \\
2 \text { private }\end{array}$ & $\begin{array}{l}2 \text { high } \\
1 \text { medium } \\
2 \text { low }\end{array}$ \\
\hline $\begin{array}{l}\text { Management: Good } \\
\text { Support Personnel: Mixed }\end{array}$ & 2 & $\begin{array}{l}1 \text { medium } \\
1 \text { large }\end{array}$ & $\begin{array}{l}1 \text { government } \\
1 \text { private }\end{array}$ & $\begin{array}{l}1 \text { medium } \\
1 \text { low }\end{array}$ \\
\hline Adequate & 1 & 1 medium & 1 government & 1 medium \\
\hline $\begin{array}{l}\text { Management: Good } \\
\text { Support Personnel: Poor }\end{array}$ & 1 & 1 large & 1 other & 1 medium \\
\hline $\begin{array}{l}\text { Management: Mixed } \\
\text { Support Personnel: Poor }\end{array}$ & 1 & 1 large & 1 government & 1 low \\
\hline Poor / Not Enough & 2 & $\begin{array}{l}1 \text { small } \\
1 \text { medium }\end{array}$ & $\begin{array}{l}1 \text { other } \\
1 \text { government }\end{array}$ & 2 high \\
\hline
\end{tabular}

Table 33: Computer Support Personnel Training

In five of the organizations, both the managers and support personnel agreed that the training provided was sufficient and, in some cases, very good. Overall, eight of the twelve organizations rated the training as adequate or better. In four organizations, there was either dissenting opinion regarding training or negative opinions on the provided training. There did not appear to be a direct relationship between the formal training provided and the effectiveness of support as two of the high effectiveness organizations ranked training as sufficient whereas the other two high effectiveness organizations rated it as insufficient. Support training did not seem to be an issue for private organizations as it was for government or other organizations. All of the private organizations had positive ratings.

${ }^{33}$ Mutually exclusive 
"Training is barely sufficient. Not as much as private industry. There is not as much [training provided] to become an expert unless you stay in position long enough but this doesn't happen because of department reorganizations." (Support, org \#8, medium government, medium effectiveness)

Organizations reported a variety of training-related issues as displayed in Table 34 ranging from time and budget constraints to lack of recognition of the cost of technical training.

\begin{tabular}{|l|c|l|l|l|}
\hline $\begin{array}{c}\text { Issues with Providing } \\
\text { Training }\end{array}$ & $\begin{array}{c}\text { \# of } \\
\text { Organizations }\end{array}$ & \multicolumn{1}{|c|}{ Size } & \multicolumn{1}{c|}{ Type } & Effectiveness \\
\hline Not Enough Time & 9 & $\begin{array}{l}2 \text { small } \\
3 \text { medium } \\
4 \text { large }\end{array}$ & $\begin{array}{l}\text { 3 government } \\
4 \text { other } \\
\text { 2 private }\end{array}$ & $\begin{array}{l}3 \text { high } \\
3 \text { medium } \\
3 \text { low }\end{array}$ \\
\hline Constrained Budget & 4 & $\begin{array}{l}1 \text { small } \\
3 \text { large }\end{array}$ & $\begin{array}{l}\text { 1 government } \\
1 \text { other } \\
2 \text { private }\end{array}$ & $\begin{array}{l}1 \text { high } \\
3 \text { low }\end{array}$ \\
\hline $\begin{array}{l}\text { No Recognition of Price } \\
\text { Difference for Technical } \\
\text { Training }\end{array}$ & 2 & $\begin{array}{l}1 \text { medium } \\
1 \text { large }\end{array}$ & $\begin{array}{l}\text { 1 government } \\
1 \text { other }\end{array}$ & 2 medium \\
\hline Not distributed fairly & 1 & 1 large & 1 government & 1 large \\
\hline
\end{tabular}

\section{Table 34: Training Issues}

Nine organizations reported that even though training was available (and even if more could be made available), it was difficult for the support personnel to find enough time to actually take the training.

"We can get training if we want it. It is difficult to have time to do." (Support, org \#12, large public, low effectiveness)

\footnotetext{
${ }^{34}$ Not mutually exclusive
} 
Constrained budgets and/or the high cost of technical training were mentioned by six organizations as limiting factors related to training.

"Not much training... the training budget is the first thing cut. I have to divide the budget between management and technical training so I only gets technical course once every two years." (Manager, org \#7, small other, high effectiveness)

"Fairly generous with training. The allocated money does not take into account that technical training is more expensive." (Manager, org \#8, medium government, medium effectiveness)

"There is a lack of proper training due to budget constraints. You must learn as you go." (Support, org \#12, large public, low effectiveness)

Two organizations reported that there was not always the understanding that technical training costs more than other business-related training leading to the feeling of inequity in the training distribution (i.e., amount and need for training versus cost of training).

"The main issue is getting people trained at the proper level on the multitude of products out there. Training is the one serious problem we have. With the training funds, there's no recognition of computer training being that much more expensive and the requirement to really increase the amount of training. We have a very hard time convincing senior management that we're any different then the finance group or someone else." (Support, org \#2, large other, medium effectiveness)

One impact resulting from lack of training was that support personnel would not be equipped to handle new applications or systems that were being provided to the users. In some cases, the support personnel saw the new technology after the user had it on their desk.

"[Training is the] \#1 complaint. Not sufficient. [Applications are] rolling out but no training to the point where people are looking around." (Support, org \#6, large government, low effectiveness) 
One organization had a solution to this problem by ensuring that the help desk is involved through out the rollout process.

"Development group gets all required training up front. We make sure that help desk gets the kind of training they need. We try to get help desk people up to speed beforehand [before major technology change] as part of rollout (before rollout happens). Application Development keeps the help desk in the loop and up to speed." (Manager, org \#2, large other, medium effectiveness)

Seven of twelve organizations reported using other methods as ways to minimize impacts due to the lack of formal training. The following table displays what organizations reported using alternate forms of training. Since this was not a prompted interview question, it is unknown whether the remaining organizations used alternate forms of training.

\begin{tabular}{|l|c|l|l|l|}
\hline $\begin{array}{c}\text { Use Alternate Forms of } \\
\text { Training }\end{array}$ & $\begin{array}{c}\text { \# of } \\
\text { Organizations } \\
\mathbf{3 5}\end{array}$ & \multicolumn{1}{|c|}{ Size } & \multicolumn{1}{|c|}{ Type } & Effectiveness \\
\hline Yes & 7 & 2 small & 2 government & 3 high \\
& $\begin{array}{c}7 \text { org \# 1,2,3,5, } \\
\text { 3 medium } \\
\text { 4 other } \\
\text { 1 large }\end{array}$ & $\begin{array}{l}3 \text { medium } \\
\text { 1 low }\end{array}$ \\
\hline Not known & 5 & $\begin{array}{l}\text { 1 small } \\
\text { 1 medium } \\
\text { 3 large }\end{array}$ & $\begin{array}{l}\text { 3 government } \\
\text { 2 private }\end{array}$ & $\begin{array}{l}\text { 1 high } \\
\text { 1 medium } \\
\text { 3 low }\end{array}$ \\
\hline
\end{tabular}

Table 35: Alternate Forms of Training

The following table displays the different types of formal training alternatives mentioned by the different organizations.

${ }^{35}$ Mutually exclusive 


\begin{tabular}{|c|c|c|c|c|}
\hline $\begin{array}{c}\text { Alternatives to Formal } \\
\text { Training }\end{array}$ & $\begin{array}{c}\text { \# of } \\
\text { Organizations }^{36}\end{array}$ & Size & Type & Effectiveness \\
\hline Cross training & $\begin{array}{c}3 \\
\text { (org \# } 1,2,7)\end{array}$ & $\begin{array}{l}2 \text { small } \\
1 \text { large }\end{array}$ & 3 other & $\begin{array}{l}1 \text { high } \\
2 \text { medium }\end{array}$ \\
\hline Self training & $\begin{array}{c}5 \\
\text { (org \#3, } 5,7,9,12\end{array}$ & $\begin{array}{l}1 \text { small } \\
3 \text { medium } \\
1 \text { large } \\
\end{array}$ & $\begin{array}{l}2 \text { government } \\
2 \text { other } \\
1 \text { private }\end{array}$ & $\begin{array}{l}3 \text { high } \\
1 \text { medium } \\
1 \text { low }\end{array}$ \\
\hline $\begin{array}{l}\text { Knowledge Transfer and } \\
\text { Training included in } \\
\text { Project Costs }\end{array}$ & $\begin{array}{c}1 \\
\text { (org \# 1) }\end{array}$ & 1 small & 1 other & 1 medium \\
\hline
\end{tabular}

\section{Table 36: Computer Support Personnel Training Comments}

Self-training was the most popular method to compensate for lack of formal training

"Availability of adequate training is a problem. Good staff spends $20-25 \%$ of spare time learning." (Manager, org \#3, medium other, high effectiveness)

"We do not receive as much training as we need. There tends to be a lot of extracurricular reading of industry documentation." (Support, org \#5, medium government, medium effectiveness)

Cross training was also used by several organizations.

"The biggest issue is lack of training. And that's not just on the client side, that's our own people (both sides need training equally as much). We do cross training of the help desk with our software groups that have really helped us a lot. We're down to one external course a year. If we want internal training, we can set that up anytime with another group so that's not too, too bad. It's just finding the time that's hard." (Support, org \#2, large other, medium effectiveness)

One organization embedded training as part as development contracts to ensure personnel receive some training on new technologies.

${ }^{36}$ Not mutually exclusive. 
"Technical Services is getting training that is more than any group in the corporation. It is getting just to the limit of what is required. When technology changes, training requirements change and you adjust. [Use workarounds such as] including consulting in project-based outsourcing for knowledge transfer and training." (Manager, org \#1, small other, medium effectiveness)

A relationship was not found between formal support staff training and support effectiveness. Specific questions on whether or not cross training, self-training and/or knowledge transfer were used in an organization were not asked. Due to the number of high and medium effectiveness organizations reporting their use, it is proposed that there is a possible relationship between alternate forms and training and support effectiveness that should be investigated in future studies. Managers should encourage, support, and reward support personnel to engage in these activities.

\subsubsection{Opinion of end users}

Computer support personnel were asked their opinion of the different end-users they encountered to see if the support staff displayed any positive or negative feelings towards the user group. This section focuses on the non-technical aspects of their comments as outlined in Table 37. The end users' computer skill level is examined on page 174. The following table displays the number of organization who reported opinions on their user groups. These answers were unprompted. 


\begin{tabular}{|c|c|c|c|c|}
\hline End User Comments & $\begin{array}{c}\text { \# of } \\
\text { Organizations }^{\mathbf{3 7}}\end{array}$ & Size & Type & Effectiveness \\
\hline Resistant to Change & $\begin{array}{c}2 \\
\text { (org \# 5,6) }\end{array}$ & $\begin{array}{l}1 \text { medium } \\
1 \text { large }\end{array}$ & 2 government & $\begin{array}{l}1 \text { medium } \\
1 \text { low }\end{array}$ \\
\hline High Expectations & $\begin{array}{c}3 \\
\text { (org \# } 1,2,4)\end{array}$ & $\begin{array}{l}1 \text { small } \\
2 \text { large }\end{array}$ & $\begin{array}{l}1 \text { government } \\
2 \text { other }\end{array}$ & $\begin{array}{l}2 \text { medium } \\
1 \text { low }\end{array}$ \\
\hline $\begin{array}{l}\text { Personality / Attitude: } \\
\text { - Mostly users with } \\
\text { good attitudes with } \\
\text { some notable } \\
\text { exceptions }\end{array}$ & $\begin{array}{c}6 \\
\text { (org \# } 1,2,4,5 \\
6,8\end{array}$ & $\begin{array}{l}1 \text { small } \\
2 \text { medium } \\
3 \text { large }\end{array}$ & $\begin{array}{l}4 \text { government } \\
2 \text { other }\end{array}$ & $\begin{array}{l}4 \text { medium } \\
2 \text { low }\end{array}$ \\
\hline
\end{tabular}

\section{Table 37: End User Opinions}

Support personnel in two organizations reported that their users were resistant to change. They needed to tailor the support to ease the users into new technology.

"Older, not inclined to technology changes, see technology benefits, have to go in slow pace, friendly if do your part and support them and follow-up, users reps in regions." (Support personnel, org \#5, medium government, medium effectiveness)

Three organizations reported that their users had high expectations although a significant differences based on expectations were not found between the organizations

"I think they expect a fairly high level of support, higher perhaps than other organizations and that might have something to do with it. "(Support personnel, org \#1, small other, medium effectiveness)

"They are very spoiled with respect to training and support. They will call someone before trying to resolve the problem themselves. Handholding. As a result our group has to be a little bigger than it would have to be if people were a little more self-sufficient (Support personnel, org \#2, large other, medium effectiveness)

\footnotetext{
${ }^{37}$ Not mutually exclusive
} 
"Very demanding group: hands-on, that's good." (Support personnel, org \#4, large government, low effectiveness)

Six organizations mentioned that although the majority of users were pleasant to deal with, there was a group of users that were difficult to deal with.

"All skill levels; some patient, some not; some nice, some rude." ... "All kinds, fairly good and reasonable in attitude, there is small group that are not the nicest that are hard to deal with" (Support personnel, org \#5, medium government, medium effectiveness).

"Some good and bad users with respect to dealing with them." (Support personnel, org $\# 8$, medium government, medium effectiveness)

"Users approachable" ... "Clients and staff friendly. It is a family atmosphere. It sometimes doesn't feel like work. Good users, sometimes here and there you have your "sticky" users. " (Support personnel, org \#4, large government, low effectiveness)

"Very open, groups are very cooperative, eager to learn." ... "Really nice ones who are very agreeable as long as you explain to them what you are doing and your approach. And you have the more difficult users who don't appreciate what's involved in development a system. Especially with all the new products that you just slap together a screen and presto. They think things could go along faster." (Support personnel, org \#1, small other, medium effectiveness)

Although, organizations where computer support personnel voiced some areas of concerns regarding the end users were mostly low and medium effective organizations, these comments were not necessarily made from a negative perspective. Do users have high expectations or do the support personnel only feel that they do? There was no significant difference found in user expectations between organizations. If users are resistant to change, how does this impact providing support? Additional research on 
these areas is required to be able to address these areas and examine their direct impacts to computer support effectiveness.

\subsubsection{View of role}

Support personnel were asked to what extent they felt they represented the support function as a whole. Respondents associated themselves most closely with their immediate group, the entire Informatics / IT / IS department, the end users, or their overall organization. In some organizations, all the interviewed support personnel replied the same way while, in others, there were mixed answers. The categorization of the answers is displayed in Table 38. No pattern between support representation and computer support effectiveness was found. 


\begin{tabular}{|l|c|l|l|l|}
\hline \multicolumn{1}{|c|}{ Representation } & \multicolumn{1}{|c|}{$\begin{array}{c}\text { \# of } \\
\text { Organizations }^{38}\end{array}$} & \multicolumn{1}{|c|}{ Size } & \multicolumn{1}{|c|}{ Type } & Effectiveness \\
\hline Majority Informatics & 3 & $\begin{array}{l}2 \text { medium } \\
1 \text { large }\end{array}$ & $\begin{array}{l}2 \text { government } \\
1 \text { other }\end{array}$ & $\begin{array}{l}1 \text { high } \\
1 \text { medium } \\
1 \text { low }\end{array}$ \\
\hline Majority Immediate Group & 2 & 2 large & $\begin{array}{l}1 \text { private } \\
1 \text { government }\end{array}$ & 2 low \\
\hline $\begin{array}{l}\text { Split between Informatics } \\
\text { and Users }\end{array}$ & 1 & 1 medium & 1 government & 1 medium \\
\hline $\begin{array}{l}\text { Split between Immediate } \\
\text { Group and Informatics }\end{array}$ & 1 & 1 medium & 1 government & 1 high \\
\hline $\begin{array}{l}\text { Split between Informatics } \\
\text { and Company }\end{array}$ & 1 & 1 small & 1 other & 1 high \\
\hline $\begin{array}{l}\text { Split between Informatics, } \\
\text { Company, and Immediate } \\
\text { Group }\end{array}$ & 3 & 1 small & $\begin{array}{l}2 \text { other } \\
1 \text { private }\end{array}$ & $\begin{array}{l}2 \text { medium } \\
1 \text { low }\end{array}$ \\
\hline
\end{tabular}

Table 38: Support Representation

\subsubsection{Turnover}

Managers and support personnel were asked if there was a large support staff turnover in their department. Two organizations reported they experienced high turnover. Neither of these organizations had a high effectiveness rating. One additional organization (small, high effectiveness) had mixed reports on turnover with some respondents indicating low tumover. Six organizations reported low turnover. Of these six organizations, only one had a low effectiveness rating. Three government

${ }^{38}$ Mutually exclusive 
departments reported that although they have low turnover with permanent employees, there is high turnover with contract staff.

The following table displays the level of turnover by number of organizations and effectiveness.

\begin{tabular}{|l|c|l|l|l|}
\hline \multicolumn{1}{|c|}{ Support Staff Turnover } & \multicolumn{1}{|c|}{$\begin{array}{c}\text { \# of } \\
\text { Organizations }\end{array}$} & \multicolumn{1}{|c|}{ Size } & Type & Effectiveness \\
\hline Low & 6 & $\begin{array}{l}2 \text { small } \\
2 \text { medium } \\
2 \text { large }\end{array}$ & $\begin{array}{l}3 \text { other } \\
1 \text { government } \\
2 \text { private }\end{array}$ & $\begin{array}{l}2 \text { high } \\
3 \text { medium } \\
1 \text { low }\end{array}$ \\
\hline $\begin{array}{l}\text { Low with permanent staff, } \\
\text { high with contractors }\end{array}$ & 3 & $\begin{array}{l}1 \text { medium } \\
2 \text { large }\end{array}$ & 3 government & $\begin{array}{l}1 \text { high } \\
2 \text { low }\end{array}$ \\
\hline $\begin{array}{l}\text { Mixed reports (some low, } \\
\text { some high) }\end{array}$ & 1 & 1 small & 1 other & 1 high \\
\hline High & 2 & $\begin{array}{l}1 \text { medium } \\
1 \text { large }\end{array}$ & $\begin{array}{l}1 \text { government } \\
1 \text { private }\end{array}$ & $\begin{array}{l}1 \text { medium } \\
1 \text { low }\end{array}$ \\
\hline
\end{tabular}

Table 39: Support Staff Turnover

Five of the six organizations with low turnover had either high or medium support effectiveness. But, there are some low effective organizations that had low turnover or low turnover with permanent staff. There may be a relationship between support effectiveness and turnover but it is not conclusive based on this study. More investigation should be done in this area.

Interview participants were asked their opinion of where people were leaving to go as well as why they were leaving. Government and Other organizations experiencing turnover as well as people who were in the process of looking for a new position, reported

${ }^{39}$ Mutually exclusive 
that their employees were looking either to the private industry or other government departments.

The most popular reasons for turnover were money and lack of advancement. Only Government or Other organizations cited this issue. The lack of job stability was also reported by two organizations: one private, one government.

"It is difficult to keep good people. Cannot offer them money or promotions. All the talk of outsourcing makes people look outside." (Manager, org \#8, medium government, medium effectiveness)

"Not much advancement. Some leave because of pay, some afraid to go to private industry because there is less security and they have to prove themselves even if they have the skills." (Manager, org \#4, large government, low effectiveness)

Please refer to Table 40 for a breakdown of answers for each of the reported turnover reasons. One organization reported that they were losing staff because of the high marketability of their skills.

"Because [IT deals with] leading edge [technology], [staff] have hot skills and may be contributing to people leaving." (Manager, org \#3, medium other, high effectiveness) 


\begin{tabular}{|l|c|l|l|l|}
\hline \multicolumn{1}{|c|}{ Turnover Reasons } & $\begin{array}{c}\text { \# of } \\
\text { Organizations }\end{array}$ & \multicolumn{1}{|c|}{ Size } & \multicolumn{1}{|c|}{ Type } & Effectiveness \\
\hline Money & 5 & $\begin{array}{l}2 \text { small } \\
1 \text { medium } \\
2 \text { large }\end{array}$ & $\begin{array}{l}2 \text { other } \\
3 \text { government }\end{array}$ & $\begin{array}{l}1 \text { high } \\
2 \text { medium } \\
2 \text { low }\end{array}$ \\
\hline Lack of advancement & 3 & $\begin{array}{l}1 \text { small } \\
1 \text { medium } \\
1 \text { large }\end{array}$ & $\begin{array}{l}1 \text { other } \\
2 \text { government }\end{array}$ & $\begin{array}{l}1 \text { high } \\
1 \text { medium } \\
1 \text { low }\end{array}$ \\
\hline $\begin{array}{l}\text { Talk about downsizing / } \\
\text { outsourcing / relocation }\end{array}$ & 2 & $\begin{array}{l}1 \text { medium } \\
1 \text { large }\end{array}$ & $\begin{array}{l}1 \text { private } \\
1 \text { government }\end{array}$ & $\begin{array}{l}1 \text { medium } \\
1 \text { low }\end{array}$ \\
\hline Boring job & 1 & 1 small & 1 other & 1 high \\
\hline $\begin{array}{l}\text { Leading edge technology } \\
\text { resulting in hot skills for } \\
\text { market }\end{array}$ & 1 & 1 medium & 1 other & 1 high \\
\hline Problems with management & 1 & 1 small & 1 other & 1 high \\
\hline
\end{tabular}

Table 40: Turnover Reasons

The interesting note on the marketability of leading edge technology skills as a turnover reason was that this was also reported as the most popular method for employee retention.

"IT staff plays with latest and greatest, keeps them motivated." (Manager, org \#11, small private, high effectiveness)

"Need fresh blood. Not much movement. Lucky to be retaining people.

[Retaining people] because moving with technology. If we slow down, may lose edge to retain them. They love to learn." (Manager, org \#3, medium other, high effectiveness)

"[Turnover] not high. We try to give them skills to compensate for lack of money with training and diversity of work. Keep [them] learning." (Manager, org \#4, large government, low effectiveness)

One organization linked the turnover versus retention battle with respect to hot technology. They were keeping staff because of the technology but, in the process, were

${ }^{40}$ Not mutually exclusive 
making their employees more attractive to the private sector offering higher salaries. For support staff, interesting work was a priority but it was more appealing if the work came with a better salary.

"[Issue with] scale of salary between government and private concerning technology. There is an aura of private industry. Don't know how long we can retain employees by progressing with technology." (Manager, org \#3, medium other, high effectiveness)

Other reasons why managers in government departments felt they were retaining their employees included training, fear of the private sector, and job security. Please refer to Table 41.

\begin{tabular}{|l|c|l|l|l|}
\hline \multicolumn{1}{|c|}{ Retention Reasons } & \multicolumn{1}{|c|}{$\begin{array}{c}\text { \# of } \\
\text { Organizations }\end{array}$} & \multicolumn{1}{c|}{ Size } & Effectiveness \\
\hline $\begin{array}{l}\text { Moving with technology } \\
\text { leading edge technology }\end{array}$ & 4 & $\begin{array}{l}1 \text { small } \\
1 \text { medium } \\
2 \text { large }\end{array}$ & $\begin{array}{l}2 \text { government } \\
1 \text { other } \\
1 \text { private }\end{array}$ & $\begin{array}{l}2 \text { high } \\
2 \text { low }\end{array}$ \\
\hline Training & 1 & 1 large & 1 government & 1 low \\
\hline $\begin{array}{l}\text { Fear of moving to private } \\
\text { sector }\end{array}$ & 1 & 1 large & 1 government & 1 low \\
\hline Job security & 1 & 1 medium & 1 government & 1 medium \\
\hline
\end{tabular}

Table 41: Retention Reasons

Managers need to understand why turnover is occurring in their organizations and find ways of retaining their staff. Although monetary compensation and advancement are two popular reasons why people leave, managers may not have any flexibility in these areas in their organizations. A common comment from the Government organizations

\footnotetext{
${ }^{41}$ Not mutually exclusive
} 
was that it was difficult to attract and keep good support staff due to the salary and hiring restrictions.

Retaining good staff was identified as important but not always easy to do. One manager stated the need "to be creative in trying to keep people and skills and be competitive." (Manager, org \# 9, medium government, high effectiveness). To attract and keep skilled support staff, the following things are recommended to IS managers:

- Provide a variety of interesting work

- Foster an environment of constant learning

"Lucky to be retaining people. We are retaining because moving with technology. If we slow down, we may lose edge to retain them. [Our staff] loves to learn." (Manager, org \#3, medium other, high effectiveness)

- Emphasize how support personnel can make a visible difference in the organization

- Provide support personnel with realistic timeframes and expectations

- Work incentives

"Motivation, bonuses, reward employees for good ideas." (Manager, org \# 11 , small private, high effectiveness)

Implement discretionary budget to provide individual or group incentives or rewards.

\subsubsection{Advancement}

Managers were asked if support personnel advanced within the support function or moved on to other areas within IS. In several organizations, there existed a tendency to 
move up the various levels of support: $1^{\text {st }}$ level to $2^{\text {nd }}$ level to $3^{\text {rd }}$ level. There was also a tendency for support personnel to move from the help desk and end user support sections to the network / LAN / communication groups or to application development if they have the applicable background.

"People move around depending on interest and demand (openings, workload). Help desk moves to LAN technology or product consulting. To advance, you have to move out of help desk. Reasons for moving: higher-level jobs have higher salaries. 80 to $90 \%$ of people who left the help desk stayed internal." (Manager, org \#2, large other, medium effectiveness)

Although the above trends in advancement were mentioned, seven organizations (see

Table 42) reported that, in reality, there was little or no movement actually occurring at that time.

"It is difficult to move people around into different functions or new areas. People tend to stay in one stream (by choice). [ ] am trying to change this. It is difficult for them to advance: promotion is difficult; impossible to create new positions." (Manager, org \#8, medium government, medium effectiveness)

"[Support personnel] sometimes lacking initiative. There is a tendency to depend on the accumulated knowledge that people have and a tendency to remain within the roles they have tended to evolve over the years." (Manager, org \#8, medium government, medium effectiveness)

"People try to advance to other areas but not a lot of movement. [Have implemented] cross-training one day a week from the help desk onto projects to help expand skills." (Manager, org \#9, medium government, high effectiveness)

The following table displays the levels of movement of their support staff between departments. 


\begin{tabular}{|c|c|c|c|c|}
\hline $\begin{array}{c}\text { Advancement } \\
\text { (Management } \\
\text { Opinion) }\end{array}$ & $\begin{array}{c}\text { \# of } \\
\text { Organizations }\end{array}$ & Size & Type & Effectiveness \\
\hline No movement & $\begin{array}{c}2 \\
\text { (org \# } 7,11 \text { ) }\end{array}$ & 2 small & $\begin{array}{l}1 \text { other } \\
1 \text { private }\end{array}$ & 2 high \\
\hline Little movement & $\begin{array}{c}6 \\
\text { (org \# 1,3,5,6, } \\
8,9 \\
\end{array}$ & $\begin{array}{l}1 \text { small } \\
4 \text { medium } \\
1 \text { large } \\
\end{array}$ & $\begin{array}{l}2 \text { other } \\
4 \text { government }\end{array}$ & $\begin{array}{l}2 \text { high } \\
3 \text { medium } \\
1 \text { low }\end{array}$ \\
\hline $\begin{array}{l}\text { Movement occurs } \\
\text { (frequency unknown) }\end{array}$ & 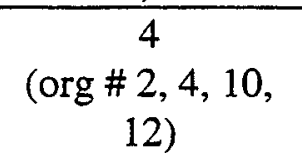 & 4 large & $\begin{array}{l}1 \text { other } \\
1 \text { government } \\
2 \text { private }\end{array}$ & $\begin{array}{l}1 \text { medium } \\
3 \text { low }\end{array}$ \\
\hline
\end{tabular}

\section{Table 42: Advancement - Movement}

Support Personnel were asked if they planned on doing support as a career or if they saw it as a stepping-stone to move on to something different. The majority of respondents $(62 \%)$ planned to stay in the support stream. $18 \%$ planned to move into management or self-employment while the remaining $20 \%$ planned to move into other technical areas. Please refer to Table 43 for a breakdown by organization.

A lot of respondents loved working in support. Of these, some planned to stay in support while others wanted to move eventually.

"I love the support side. You get complaints but you also get thank you's. One on one. I plan to stay in support" (Support personnel, org \#6, large government, low effectiveness)

The following table displays the support personnel career plans by organization and effectiveness. The categories represent the area where the support personnel would like

\footnotetext{
${ }^{42}$ Mutually exclusive
} 
to move to next. "Split" answers denote that of the support personnel interviewed from a single organization, they had different career plans in mind.

\begin{tabular}{|l|c|l|l|l|}
\hline \multicolumn{1}{|c|}{ Career } & \multicolumn{1}{|c|}{$\begin{array}{c}\text { \# of } \\
\text { Organizations }\end{array}$} & \multicolumn{1}{|c|}{ Size } & \multicolumn{1}{|c|}{ Type } & Effectiveness \\
\hline $\begin{array}{l}\text { Majority plan on doing } \\
\text { support as career }\end{array}$ & 7 & $\begin{array}{l}2 \text { small } \\
2 \text { medium } \\
3 \text { large }\end{array}$ & $\begin{array}{l}3 \text { government } \\
3 \text { other } \\
1 \text { private }\end{array}$ & $\begin{array}{l}\text { 2 high } \\
3 \text { medium } \\
2 \text { low }\end{array}$ \\
\hline $\begin{array}{l}\text { Majority plan to move into } \\
\text { another technical area }\end{array}$ & 1 & 1 medium & 1 government & 1 medium \\
\hline $\begin{array}{l}\text { Split between support and } \\
\text { management as a career }\end{array}$ & 2 & $\begin{array}{l}1 \text { medium } \\
1 \text { large }\end{array}$ & $\begin{array}{l}1 \text { government } \\
1 \text { other }\end{array}$ & $\begin{array}{l}1 \text { high } \\
1 \text { low }\end{array}$ \\
\hline $\begin{array}{l}\text { Split between support and } \\
\text { another technical area }\end{array}$ & 1 & 1 small & 1 private & 1 high \\
\hline $\begin{array}{l}\text { Split between management } \\
\text { and support/technical }\end{array}$ & 1 & 1 large & 1 private & 1 low \\
\hline
\end{tabular}

\section{Table 43: Advancement - Career}

\section{Move to Management}

"I plan to stay at the help desk to learn everything about company before moving on to something else. I see it as a stepping stone to mgt." (Support personnel, org $\# 12$, large private, low effectiveness)

"This could be a career, because it's fun, enjoys it, has some laughs, it's always different. Like because of the variety, the challenge, constant learning, stressful situations (likes), likes technical/managerial mix." (Support personnel, org \#2, large other, medium effectiveness)

"I like support but getting very complicated. I want to go into management" (Support personnel, org \#6, large government, low effectiveness)

${ }^{43}$ Mutually exclusive 


\section{Move to Other Technical Areas}

"Enjoy what I do but would like to do more development. Want some tech support \& some development work or to move to server group where you're not really on-call for clients. Doesn't want to be constantly dealing with people." (Support personnel, org \#8, medium government, medium effectiveness)

"I used to be a system administrator. I see this position [current job] as a step down. I like dealing with people but would like to move to the network side but with client interaction" (Support personnel, Org \#4, large government, low effectiveness)

Support people in two organizations were planning to move onto something different not because they wanted to but because of the money (Org \#2, large other, medium effectiveness; org \#4, large government, low effectiveness).

"I find support much more interesting than network. I will go to the server side because only way to get more money." (Support personnel, org \#4, large government, low effectiveness)

"I plan to spend my career at the help desk. I'd say the majority of the help desk analysts (3-4 out of 6) are happy but want to move on. Possibly because of type of work or money.)" (Support personnel, org \#2, large other, medium effectiveness)

Support people in two organizations wanted to move into less user-intensive roles (Org $\# 5$, medium government, medium effectiveness, org \#8, medium government, medium effectiveness).

"My next step is onto something else. I am aiming more for the network management side. It is hard dealing with the constant pressure of dealing with user demands. You can see people burning out after awhile." (Support personnel, org \#5, medium government, medium effectiveness)

Four of the organizations reporting little or no actual movement in their staff had high support effectiveness ratings (see Table 42). Of these organizations, two reported 
that their staff planned to stay in support as their career choice while the other two had personnel planning on doing support as a career as well as personnel planning to move to management or another technical area. The fact that there was little movement in these highly effective organizations could represent that people are satisfied with their jobs and are on the correct path to pursue their career aspirations. To test this theory, reported job satisfaction in these organizations was also examined. Of the seven organizations reporting little to no movement:

- All support personnel in the four highly effective organizations and one medium effective organization reported that they were either satisfied or very satisfied with their jobs.

- The other medium effective organization reported that their support personnel were mostly satisfied (three people satisfied, one not)

- The low effective organization reported that the majority of their staff was not satisfied with their job.

It appears that support departments experiencing little staff movement are as a result of good job satisfaction with the good job satisfaction resulting in effective support. Please refer to section 4.6.1.11 for a detailed analysis of job satisfaction. There did not appear to be a relationship between career aspirations and support effectiveness. 


\subsubsection{Morale}

Support personnel were asked to rate the morale in their department. Of the eleven responding organizations, seven rated their department's morale as good or pretty good with seven rating them or somewhat poor or poor. Please refer to Table 44 for the breakdown of the organizations by morale categories.

\begin{tabular}{|l|c|l|l|l|}
\hline \multicolumn{1}{|c|}{ Morale } & $\begin{array}{c}\text { \# of } \\
\text { Organizations }^{44}\end{array}$ & \multicolumn{1}{|c|}{ Size } & \multicolumn{1}{|c|}{ Type } & Effectiveness \\
\hline Good & 4 & $\begin{array}{l}2 \text { small } \\
2 \text { large }\end{array}$ & $\begin{array}{l}3 \text { other } \\
1 \text { private }\end{array}$ & $\begin{array}{l}1 \text { high } \\
2 \text { medium } \\
1 \text { low }\end{array}$ \\
\hline Pretty Good & 3 & $\begin{array}{l}1 \text { small } \\
1 \text { medium } \\
1 \text { large }\end{array}$ & $\begin{array}{l}1 \text { other } \\
2 \text { private }\end{array}$ & $\begin{array}{l}2 \text { high } \\
1 \text { low }\end{array}$ \\
\hline Somewhat Poor & 2 & $\begin{array}{l}1 \text { medium } \\
1 \text { large }\end{array}$ & 2 government & $\begin{array}{l}1 \text { medium } \\
1 \text { low }\end{array}$ \\
\hline Poor & 2 & $\begin{array}{l}1 \text { medium } \\
1 \text { large }\end{array}$ & 2 government & $\begin{array}{l}1 \text { medium } \\
1 \text { low }\end{array}$ \\
\hline
\end{tabular}

Table 44: Support Personnel Morale

A trend was apparent between morale and organizational effectiveness where all high effectiveness organizations reporting pretty good or good morale and all low effectiveness organizations reporting somewhat poor or poor morale. There was a definite relationship between organization type and morale with all of the government organizations reported

${ }^{44}$ Mutually exclusive 
somewhat poor or poor morale. This could be mostly due to the job unicertainty and government cutbacks that were underway at the time.

Seven organizations, as outlined in Table 45, reported issues with job uncertainty impacting morale. Comments included:

"Outsourcing talk is negatively impacting morale." (Manager, org \#2, medium other, low effectiveness

"Cutbacks making people nervous." (Support personnel, org \#9, medium government, high effectiveness)

"Good atmosphere, users' morale lately lower because a lot will be laid off shortly." (Support personnel, org \#7, small other, high effectiveness)

"Morale in government not great (job security)... hurts workplace." (Manager, org \#3, medium other, high effectiveness)

"[Had problem with] orientation of groups and morale because of cutbacks ... [To solve] encouraging contact, activities, etc." (Manager, org \# 9, medium government, high effectiveness)

"On par with the total [job] uncertainty." ... "A lot of people sending out resumes." (Support personnel, org \#2, large other, medium effectiveness)

"When things going good, fairly good; when going bad, bad. Problem is not when system goes down but when the contract comes up for negotiations, government constraints, stagnation lowers morale as does wage freeze." (Support personnel, org $\# 3$, medium other, high effectiveness)

The following table displays the number of organizations where managers and/or staff reported (unprompted) that they were in period of job uncertainty. 


\begin{tabular}{|l|c|l|l|l|}
\hline \multicolumn{1}{|c|}{ Job Uncertainty } & \multicolumn{1}{|c|}{$\begin{array}{c}\text { \# of } \\
\text { Organizations }\end{array}$} & \multicolumn{1}{|c|}{ Type } & Effectiveness \\
\hline Job Uncertainty & 7 & $\begin{array}{l}1 \text { small } \\
2 \text { medium } \\
4 \text { large }\end{array}$ & $\begin{array}{l}3 \text { government } \\
\text { other } \\
1 \text { private }\end{array}$ & $\begin{array}{l}3 \text { high } \\
1 \text { medium } \\
3 \text { low }\end{array}$ \\
\hline
\end{tabular}

Table 45: Job Uncertainty

The main areas that emerged as having negative impacts on morale included restructuring, lack of advancement, management issues, and lack of money.

\section{$\underline{\text { Restructuring }}$}

"Morale is pretty low because of restructuring. Changes are coming. They are reclassifying positions and term positions are being downsized." (Support personnel, org \#4, large government, low effectiveness)

"Morale is normally good but it is lately strained because of restructuring." (Support personnel, org \#4, large government, low effectiveness

\section{Lack of Advancement}

"Morale is fair because there doesn't seem to be any room for advancement. It is pretty stagnant" (Support personnel, org \#5, medium government, medium effectiveness)

\section{Management Issues}

"Morale is up and down because there a lot of work and management doesn't understand what you're going through." (Support personnel, org \#9, medium government, high effectiveness)

"Morale is very, very poor because of management." (Support personnel, org \#5, medium government, medium effectiveness)

"There is a lack of defined roles and structure. It is difficult to initiate change. I am doing more things than role and want to get paid for it." (Support personnel, org \#12, large private, low effectiveness)

"Morale is quite good. There are a few pockets of staff who may not be pleased in the lower levels due to way they are being managed." (Support personnel, org \#3, medium other, high effectiveness) 
Money

"Morale is low because of money and lack of cohesiveness in unit. There is always infighting. I like company." (Support personnel, org \#12, low private, low effectiveness)

"Management is not good in building morale. Consultants make a lot more money [then full-time staff]." (Support personnel, org \#6, large government, low effectiveness)

IS managers can look at items that have positive impacts on morale, such as a fun, social work atmosphere and the presence of challenging work, to try and compensate for some of the negative morale impacts that they are unable to influence (e.g., money, advancement).

$\underline{\text { Social }}$

"Everyone gets along great, nice atmosphere, fun, social." ... "Morale is pretty good except for on stressful days. There is a social atmosphere and company activities." (Support personnel, org \#12, large private, low effectiveness)

\section{Challenging work}

"Morale seems to be quite high. There is always challenging work and stuff. I think morale comes into play with external factors not internal to the department: what's happening to the corporation as a whole." (Support personnel, org \#1, small other, medium effectiveness)

Based on the support personnel morale answers in Table 44, it is hypothesized that poor support personnel morale results in lower levels of computer support effectiveness 


\subsubsection{Stres.s}

- Support personnel rated their stress level resulting in rankings of high to moderate by organization as displayed in Table 46 .

\begin{tabular}{|l|c|l|l|l|}
\hline \multicolumn{1}{|c|}{ Stress } & $\begin{array}{c}\text { \# of } \\
\text { Organizations }\end{array}$ & \multicolumn{1}{|c|}{ Size } & \multicolumn{1}{|c|}{ Type } & Effectiveness \\
\hline High & 3 & 3 large & $\begin{array}{l}\text { 1 government } \\
\text { 2 private }\end{array}$ & 3 low \\
\hline Moderately high & 4 & $\begin{array}{l}1 \text { small } \\
2 \text { medium } \\
1 \text { large }\end{array}$ & $\begin{array}{l}1 \text { government } \\
2 \text { other } \\
1 \text { private }\end{array}$ & $\begin{array}{l}2 \text { high } \\
2 \text { medium }\end{array}$ \\
\hline Cyclical & & $\begin{array}{l}1 \text { small } \\
1 \text { medium } \\
1 \text { large }\end{array}$ & $\begin{array}{l}2 \text { government } \\
1 \text { other }\end{array}$ & $\begin{array}{l}1 \text { high } \\
1 \text { medium } \\
1 \text { low }\end{array}$ \\
\hline Moderate & 3 & $\begin{array}{l}1 \text { small } \\
1 \text { medium }\end{array}$ & $\begin{array}{l}1 \text { government } \\
1 \text { other }\end{array}$ & $\begin{array}{l}1 \text { high } \\
1 \text { medium }\end{array}$ \\
\hline
\end{tabular}

Table 46: Stress

All three organizations reporting high stress levels were large organizations with low effectiveness. As well, all of the private organizations reported either moderately high or high stress levels. This information leads to the following hypotheses:

- Organizations reporting high levels of stress with their support personnel provide ineffective computer support.

- Support personnel reporting high levels of stress are more prevalent in large organizations

${ }^{45}$ Mutually exclusive 
Support personnel in private organizations reported higher levels of stress than personnel in government or other organizations.

Although one organization reported that the job was stressful because of poor morale, it stated that the stress related to the type of work was not a problem. This type of stress was reported as being "good stress" (Support personnel, org \#5, medium government, medium effectiveness). Several organizations reported stress problems directly related to their work. The main reported causes for the stress were:

- High numbers of problems to get fixed

"Stress is extremely high, mostly in a panic." (Support personnel, org \#12, large private, low effectiveness)

"More stress on consultants. They run around like being paid by problem ticket." (Support personnel, org \#6, large government, low effectiveness)

"Stress is very high. There is pressure to get problems fixed" (Support personnel, org \#10, large private, low effectiveness)

- Severity of problems

"Stress is very high, not due to the number of calls but due to the severity. If we lose a server here, there's high pressure to get it back running." (Support personnel, org \#2, large other, medium effectiveness)

- Dealing with users: high profile, direct contact

"Stress varies depending on client. The higher up the client, the more stress." (Support personnel, org \#4, large government, low effectiveness)

"Sometimes very stressful. The front-end [staff] feels the heat whereas backend does not." (Support personnel, org \#6, large government, low effectiveness)

- Managing workload and priorities

"[Stressful because] managing workload and a number of priorities at the same time. You have to constantly sell something to the user or talk to them in their language and strive to meet targets." (Support personnel, org $\# 3$, medium other, high effectiveness) 
- Cyclical nature

"The stress is cyclical and sporadic. It is hard to handle because not used to it." (Support personnel, org \#12, large private, low effectiveness)

"Hectic because of deadlines for upgrades and a lot of overtime. The stress levels fluctuate." (Support personnel, org \#4, large government, low effectiveness)

"When there is a normal amount of work, stress is very very low. When projects with high priorities, the stress levels tends to be a bit higher. It is cyclical and varies on the project and deadline." (Support personnel, org \#1, small other, medium effectiveness)

"Right now [stress levels are] high because of migration, new management, and reorganization." (Support personnel, org \#4, large government, low effectiveness)

"Right now [stress] is high because of transition. Everybody's working kind of day to day and we seem to be managing it quite well, with a positive attitude." (Support personnel, org \#2, large other, medium effectiveness)

A hypothesis was proposed above that high stress leads to low computer support effectiveness. Some reasons for this relationship could be that employees who experience high levels of stress or who are not able to deal with the stress in a manageable way are not able to perform their jobs to the best of their abilities. In some cases, this may lead to employees looking for employment elsewhere.

"Very stressful, thinking of changing places." (Support personnel, org \#6, large government, low effectiveness)

As well, this study's results proposed that support personnel in large organizations have higher stress levels. In larger organizations, there may be more projects going on at the same time causing more frequent cyclical peaks in the workload and stress levels. As 
well, support personnel in large organizations may deal with a broader user base resulting in additional stress trying to adapt to meet the various user needs.

It has also been proposed that support personnel in private organizations experience higher levels of stress. In the quotes above, one private organization reported the high pressure to get problems solved, as well, one governmental organization reported that stress was a lot higher with its consultants then its permanent staff. Since, in most organizations, there are always times when the workload is very high, private or contract staff may feel greater pressure to produce to meet these demands to ensure their job security. Perceptions of job security were not examined as part of this study but would be useful in future studies.

Managers should invest effort into implementing formal problem prioritization methodologies. Stress management and time management courses for staff members would also be useful. This would have a positive influence on stress since many of the above reasons for stress revolved around workload, numbers of problems, and problems severity. Please refer to section 4.8.1.4 for additional information on problem prioritization.

\subsubsection{Job satisfaction/motivation}

Support personnel were asked how satisfied they were with their job. Answers were categorized as displayed in Table 47. 


\begin{tabular}{|l|c|l|l|l|}
\hline \multicolumn{1}{|c|}{ Job Satisfaction } & $\begin{array}{c}\text { \# of } \\
\text { Organizations }\end{array}$ & \multicolumn{1}{c|}{ Size } & \multicolumn{1}{c|}{ Type } & Effectiveness \\
\hline $\begin{array}{l}\text { All Satisfied or Very } \\
\text { Satisfied }\end{array}$ & 7 & $\begin{array}{l}2 \text { small } \\
3 \text { medium } \\
\text { 2 large }\end{array}$ & $\begin{array}{l}\text { 2 other } \\
\text { 3 government } \\
\text { 2 private }\end{array}$ & $\begin{array}{l}4 \text { high } \\
\text { 1 medium } \\
2 \text { low }\end{array}$ \\
\hline Most Respondents Satisfied & 3 & $\begin{array}{l}\text { 1 small } \\
\text { 2 large }\end{array}$ & $\begin{array}{l}\text { 2 other } \\
\text { 1 private }\end{array}$ & $\begin{array}{l}2 \text { medium } \\
1 \text { low }\end{array}$ \\
\hline Somewhat Satisfied & 1 & 1 medium & 1 government & 1 medium \\
\hline Most Not Satisfied & 1 & 1 large & 1 government & 1 low \\
\hline
\end{tabular}

\section{Table 47: Support Personnel Job Satisfaction}

In seven of the twelve organizations, all interviewed support personnel reported that they were satisfied with their jobs. All of the highly effective organizations were ranked in this category. Medium and low effective organization were split among all the categories.

In three organizations, most of the support personnel were satisfied whereas one organization had personnel who were somewhat satisfied. Only one organization had personnel that were mostly not satisfied and this organization had a low effectiveness rating. Private and other organizations reported that either most or all of their support personnel were satisfied. Government organizations were split between the different categories. Small organizations reported that either most or all of their support personnel were satisfied. Medium and large organizations were split between the categories. Since there were several medium, large, and government organizations reporting good job

${ }^{46}$ Mutually exclusive 
satisfaction ratings, it does not appear that there are any specific trends for company size and type with job satisfaction.

Based on the highly effective support organizations reporting good satisfaction levels, it is hypothesized that organizations where computer support personnel experience job satisfaction provide effective computer support.

Why are support personnel satisfied with their jobs? Support personnel love the continual learning that goes along with the job as well as the ability to make an impact. Experiencing good relationships with their team and being recognized for a job well done were also influencing factors. IS managers should look at these factors to improve job satisfaction in their groups.

\section{Continual Learning}

"Really like [my job]. There is always new stuff. It is interesting finding solutions to problems." (Support personnel, org \#5, medium government, medium effectiveness)

"Work is pretty good. Yes, I have job satisfaction. It is challenging and you learn all the time. It is a continual learning process that never ends." (Support personnel, org \#11, small private, high effectiveness)

"[The job] is challenging. There's always something to learn." (Support personnel, org \#1, small other, medium effectiveness)

"I am very satisfied with my job. Money is not the major role. I am looking for a challenge." (Support personnel, org \#3, medium other, high effectiveness)

$\underline{\text { Impact }}$

"Good [job satisfaction]. I have a lot of influence and flexibility in terms of projects." (Support personnel, org \#12, large private, low effectiveness)

"I am very satisfied. One of the things that keep my satisfaction level high is that I have a reasonable amount of autonomy. ... We're a small shop so I'm not specialized in any one thing. I get to see the entire project from start to end and 
that's very satisfying. ... I have quite a bit of impact of things happening over the next year." (Support personnel, org \#1, small other, medium effectiveness)

\section{Relationships / Recognition}

"I am pretty well satisfied because I have good relationships with my supervisors and the people I work with. I personally got recognition on good interrelationship with clients." (Support personnel, org \#8, medium government, medium effectiveness)

"On the whole, I am pretty satisfied. There are better days, like when users say thanks." (Support personnel, org \#5, medium government, medium effectiveness)

What factors negatively impact job satisfaction? A few computer support

personnel mentioned the lack of job security and money. Others mentioned the high volumes of work as well as the need to fix the same problems over and over.

Job security

"[My job satisfaction] is higher than medium. I am not extremely satisfied but like the role I am playing. If it was a permanent position, I would be extremely happy. Only in temp position." (Support personnel, org \#6, large government, low effectiveness)

Money

"Not overly satisfied. Just doing it. Probably due to the money I'm making. My salary is middle of the road for my skill set. I enjoy the work." (Support personnel, org \#1, small other, medium effectiveness)

Amount of work

"There's a general malaise over the current transition. Malaise over the amount of work. A lot of different problems from our complex environment." (Support personnel, org \#2, large other, medium effectiveness)

\section{Problem Reoccurrence}

"Not always satisfied. I liked programming. [In support], there are too many problems facing the client all the time. Some things happen and will re-happen again and again." (Support personnel, org \#8, medium government, medium effectiveness) 
One manager was trying to keep his employees notivated during a difficult period by keeping them challenged and showing technological advancement (Manager, org \#10, large private, low effectiveness).

Job satisfaction is an important factor in the ability to provide effective computer support.

\subsubsection{Commitment}

To gauge the level of commitment support personnel had for their job, they were asked how much overtime they worked. The results are displayed in Table 48. No trends between overtime and computer support effectiveness were found.

\begin{tabular}{|l|c|l|l|l|}
\hline \multicolumn{1}{|c|}{ Overtime } & \multicolumn{1}{|c|}{$\begin{array}{c}\text { \# of } \\
\text { Organizations }\end{array}$} & \multicolumn{1}{|c|}{ Size } & \multicolumn{1}{|c|}{ Type } & Effectiveness \\
\hline A lot of overtime required & 2 & $\begin{array}{l}1 \text { small } \\
1 \text { medium }\end{array}$ & $\begin{array}{l}1 \text { government } \\
1 \text { private }\end{array}$ & $\begin{array}{l}1 \text { high } \\
1 \text { medium }\end{array}$ \\
\hline $\begin{array}{l}\text { Overtime required causing } \\
\text { stress }\end{array}$ & 1 & 1 large & 1 private & 1 low \\
\hline $\begin{array}{l}\text { Overtime is cyclical, } \\
\text { personnel do not feel it is a } \\
\text { problem }\end{array}$ & 2 & $\begin{array}{l}1 \text { medium } \\
1 \text { large }\end{array}$ & $\begin{array}{l}1 \text { government } \\
1 \text { other }\end{array}$ & $\begin{array}{l}1 \text { high } \\
1 \text { low }\end{array}$ \\
\hline $\begin{array}{l}\text { Not much or no overtime } \\
\text { required }\end{array}$ & 6 & $\begin{array}{l}2 \text { small } \\
2 \text { medium } \\
2 \text { large }\end{array}$ & $\begin{array}{l}2 \text { government } \\
\text { other } \\
1 \text { private }\end{array}$ & $\begin{array}{l}1 \text { high } \\
4 \text { medium } \\
1 \text { low }\end{array}$ \\
\hline $\begin{array}{l}\text { Mixed answers: None to a } \\
\text { lot }\end{array}$ & 1 & 1 large & 1 government & 1 low \\
\hline
\end{tabular}

Table 48: Overtime

${ }^{47}$ Mutually exclusive 
Based on the answers to the overtime question, it was apparent that there was a distinction between unpaid overtime done just to be able to complete a job to a person's personal satisfaction versus paid overtime done because it was a required component of the job. This level of questioning was not done as part of the study. The amount of overtime was not a good indicator of job commitment. A new measure should be used in future studies. One possibility is to ask managers to gauge the level of commitment of their staff. When asked about past problems and how they were corrected, one manager noted:

"We had some problems with staff who were not committed enough to job or not able to pick up knowledge. [To solve this problem], we put people on training and got them to tag along with peers. But, most of my people have been extremely dedicated." (Manager, org \# 8, medium government, medium effectiveness)

\subsubsection{Communication between Support Personnel and IS Management}

Support personnel and managers were asked to comment on the communication between support personnel and IS management in their organization. Based on the comments, the organizations were categorized into whether communication was described as good, had some issues, or was a definite problem. Please refer to Table 49 for the breakdown of the communication ratings by organization and effectiveness. 


\begin{tabular}{|c|c|c|c|c|}
\hline Communication & $\begin{array}{c}\text { \# of } \\
\text { Organizations }^{48}\end{array}$ & Size & Type & Effectiveness \\
\hline Good & 6 & $\begin{array}{l}2 \text { small } \\
4 \text { medium }\end{array}$ & $\begin{array}{l}2 \text { other } \\
3 \text { government } \\
1 \text { private }\end{array}$ & $\begin{array}{l}4 \text { high } \\
2 \text { medium }\end{array}$ \\
\hline Some Issues & 5 & $\begin{array}{l}1 \text { small } \\
1 \text { medium } \\
3 \text { large }\end{array}$ & $\begin{array}{l}2 \text { other } \\
1 \text { government } \\
2 \text { private }\end{array}$ & $\begin{array}{l}2 \text { medium } \\
3 \text { low }\end{array}$ \\
\hline Definite Problem & 1 & 1 large & 1 government & 1 low \\
\hline
\end{tabular}

Table 49: Communication between Support Personnel and IS Management

All organizations with good communication between support staff and IS management were highly or medium effective. No large organizations experienced good communication. Based on these results, it is hypothesized that:

- Good communication between support personnel and IS management leads to better computer support effectiveness.

- Larger organizations experience more issues with communication between IS management and staff.

One support person said that one of the challenges with communication is that "you have to adjust yourself at a user level, colleague level, and management level." (Support personnel, org \#5, medium government, medium effectiveness). Some of the reported communication issues were interpreting "technical" speak and being too sensitive:

"Little problems escalate because communication between techies. You need someone to interpret." (Support personnel, org \#12, large private, low effectiveness)

${ }^{48}$ Mutually exclusive 
"People are too friendly. They are afraid of hurting someone's feelings instead of dealing with problem. Too sensitive. Moving people around instead of fixing problem." (Manager, org \#4, large government, low effectiveness)

Improving the communication between the support personnel and IS management would help provide more effective computer support. IS managers should try some of the following recommendations to improve communication with their staff:

- Solicit and listen to their staff's opinion on issues. One person reported that they "get feedback from management but the staff's word is not important at current time. They are starting to listen." (Support personnel, org \#4, large government, low effectiveness). Follow up with staff and work with them to ensure they understand the business reasons regarding why decisions were made, particularly when the decisions differ from the opinions provided by the staff.

- Be direct. Provide constructive criticism. If issues are not discussed and handled, they will worsen with time.

- Ensure two-way communication and feedback channels are in place.

- Improve the filtering of information from management to the support staff (Support personnel, Org \#12, large private, low effectiveness). This will eliminate superfluous information going to the support staff that does not directly relate to their job or their understanding of the users needs. The 
filtered information should be made available (e.g., in a shared repository) but should not hide the more critical information that needs to get through.

\subsubsection{Summary of Support Personnel Hypotheses}

The following hypotheses were proposed regarding support personnel and computer support effectiveness. Hypotheses tagged 'NEW' were not validated based on the study's data but were evaluated to be worth further study based on a combination of interview comments and past research.

1. Support departments with good job satisfaction experience little staff movement.

2. There is a positive relationship between support personnel morale and support effectiveness.

3. Morale for support personnel in government organizations is lower than private or other organizations.

4. Organizations reporting high levels of stress with their support personnel provide ineffective computer support.

5. Support personnel reporting high levels of stress are more prevalent in large organizations

6. Support personnel in private organizations reported higher levels of stress than personnel in government or other organizations.

7. Organizations where computer support personnel experience job satisfaction provide effective computer support 
8. Computer support effectiveness is increased when there is good communication between support personnel and IS management.

9. Large organizations experience more issues with communication between IS management and staff.

10. NEW: Support personnel with good people skills and the ability to translate technical to/from business language result in effective computer support.

11. NEW: The use of alternate forms of support personnel training (e.g., cross training, self training, knowledge transfer) leads to more effective computer support.

\subsection{End User Experience/Needs}

\subsubsection{Discussion}

Various areas concerning the end users' experience and needs were investigated to look at possible relationships to the effectiveness of the support function in researching the following question:

Research Question \#5: How do end user experience / needs influence the effectiveness of the computer support function?

The following areas were examined:

- Computer skill level

- Type of support required and reason for requiring

- Training

- Peer support 
- Communication

- Other reported end user issues

\subsubsection{Demographics}

Demographic information was collected from the survey respondents with respect to age, gender, years worked in organization, functional area, and educational experience. The ages of the respondents in all the organizations ranged from 22 to 62 with an average age of 40 . In all the organizations, $57 \%$ of the respondents are female while $43 \%$ are male.

The users have worked various numbers of years in their present organization. Overall, people have worked in their present organization for between 3 months and 30 years with an average of 9 years.

The respondents held various positions in their organizations as displayed in Table 50.

\begin{tabular}{|l|c|}
\hline \multicolumn{1}{|c|}{ Level } & Overall \\
\hline Executive & $5 \%$ \\
\hline Manager & $21 \%$ \\
\hline Supervisor & $14 \%$ \\
\hline Professional & $21 \%$ \\
\hline Technical & $7 \%$ \\
\hline
\end{tabular}




\begin{tabular}{|l|c|}
\hline Clerical & $21 \%$ \\
\hline Other & $11 \%$ \\
\hline
\end{tabular}

\section{Table 50: Job Levels}

The educational background of the users also varied. $67 \%$ of the overall respondents had a college diploma (20\%), university degree (33\%), and/or graduate degree (14\%). $19 \%$ of the respondents had taken some college or university courses.

\subsubsection{Computer skill level}

All organizations reported a range of users from novice to expert. Respondents in all organizations used a computer several times a day. The overall average for computer use in a day was 4.7 hours.

The Information Technology familiarity looked at the number of software packages a person was able to use and how many technology concepts they understood. This study examined the depth, breadth, and finesse of a user's knowledge of Information Technology. The depth of a person's knowledge of Information Technology represented how thorough a person understood a software package or technology concept. The breadth of a person's Information Technology knowledge represented the expanse of their knowledge of software packages or technology concepts (e.g., how many packages/concepts they knew). Finally, finesse represented the level of a person's ability to creatively apply computer concepts to solve work problems. 
Depth, breadth, and finesse were all ranked on a scale of the number of concepts the users knew, how much of these concepts they knew, and how well they were able to apply the concepts.

If users had lower than average values on the depth, breadth, and finesse concepts, they did not know as many software packages and concepts and did not know them as thoroughly as the overall average. They also found it harder than the average user to apply these concepts to their work.

The question of whether the level of computer competency of a user is related to their perceived level of service quality was examined by looking at the relationship between service quality and breadth, depth, and finesse. The depth, breadth, and finesse variables were also normalized and then averaged to create an overall IT familiarity indicator. This indicator was than categorized into three ratings: low, medium, and high. The results by organization are displayed in Table 51 .

A significant relationship was found between computer support effectiveness and each of depth, breadth, and an overall IT familiarity indicator. Details are displayed in the following table. 


\begin{tabular}{l|l|r|r|r|r|}
\hline Correlations & DEPTH & BREADTH & FINESSE & $\begin{array}{c}\text { Overall IT } \\
\text { Familiarity }\end{array}$ \\
\hline \multirow{3}{*}{$\begin{array}{l}\text { Support } \\
\text { Effectiveness }\end{array}$} & $\begin{array}{l}\text { Pearson } \\
\text { Correlation }\end{array}$ & $-.130\left(^{*}\right)$ & $-.188\left(^{* *}\right)$ & -.104 & $-.151\left(^{*}\right)$ \\
\cline { 2 - 6 } & Sig. (2-tailed) & .049 & .004 & .113 & .020 \\
\cline { 2 - 6 } & $\mathrm{N}$ & 231 & 230 & 233 & 238 \\
\hline
\end{tabular}
** Correlation is significant at the 0.01 level (2-tailed).
Correlation is significant at the 0.05 level (2-tailed).

A small negative relationship was found between breadth, depth, overall IT familiarity and computer support effectiveness. The more competent the user was, the lower their level of their perceived support effectiveness. There was no significant relationship between the IT familiarity indicators and user expectations ${ }^{49}$.

Why would higher overall IT familiarity result in lower service quality ratings? An initial reaction was that advanced users would have higher expectations but this relationship was not supported. One organization (org \#9, medium, government, high effectiveness) was an exception to the hypothesis as it had high IT familiarity ratings as well as high computer support effectiveness. This organization reported performing the following things to meet the needs of their user base:

- Documenting tips and tricks for their users

- Promoting courses and providing training on all the environment

\footnotetext{
${ }^{49}$ As calculated by the expectations-only SERVQUAL instrument using Pearson correlation.
} 
- Putting a lot of effort into understanding their users' needs and keeping users informed.

- Assigning specific IT contacts in each section

Taking some points from this exception, an explanation for the negative relationship between IT familiarity and computer support effectiveness could be that, in many organizations, end user training only covered basic skills so the level of help required by the advanced user was more complex. Advanced users could be less satisfied due to their need for a higher level of support. Because front-line staff tended to be junior, they did not have the experience or knowledge to solve complex problems. The support organization may not have addressed the differing needs of the advanced users and managed expectations appropriately.

"And you have the more difficult users who don't appreciate what's involved in development a system. Especially with all the new products that you just slap together a screen and presto. They think things could go along faster." (Support personnel, org \#1, small other, medium effectiveness)

In addition to IT familiarity instrument in the end user questionnaires, managers and support personnel in each organization were asked to rate their user's skill level. The results are displayed in Table 51. It was interesting to note that organizations whose IT familiarity rankings were high felt that their user base had novice-intermediate skills. For example, in organization \#4 (large government, low effectiveness), the overall IT 
familiarity rating indicated users were comfortable with computers ${ }^{50}$ but the managers and support personnel interviewed indicated that the majority of their users were novice. In this organization, no issues were found with the communication between users and IT eliminating this as a possible cause. Support personnel felt that their users were very demanding and hands-on and spent time teaching the users new skills. These reports supported the high overall IT familiarity rating. The support personnel may have gained a wrong impression of the average skill set of the users in their organization since they received more calls from the novice users than power users.

Managers and support personnel in all organizations were asked what type of user required more support. A common opinion was novice users called more often but their problems were easier and quicker to fix whereas expert users called less but their complex problems took longer to solve, resulting in both sets of users using the same amount of support.

${ }^{50}$ Organization \#4 had the highest rating of depth, breadth, and finesse of all participating organizations. 


\begin{tabular}{|c|c|c|c|}
\hline Organization & $\begin{array}{c}\text { IT } \\
\text { Familiarity }\end{array}$ & $\begin{array}{c}\text { Level of Users } \\
\text { (Opinion of } \\
\text { Managers and } \\
\text { Support } \\
\text { Personnel) } \\
\end{array}$ & $\begin{array}{c}\text { Who Requires More Support? } \\
\text { M: Manager } \\
\text { S: Support Personnel }\end{array}$ \\
\hline $\begin{array}{l}\text { Org } 1 \text { (small, } \\
\text { other, medium } \\
\text { effectiveness) }\end{array}$ & Medium & $\begin{array}{l}\text { Variety, have } \\
\text { sophisticated } \\
\text { and very good } \\
\text { users, } 30 \% \\
\text { power users }\end{array}$ & $\begin{array}{l}\text { M: "Equally as hard" } \\
\text { S: "The dangerous ones have a PC at home and think they } \\
\text { can configure things by themselves." } \\
\text { S: "Power users are a little more difficult to deal with } \\
\text { fbecause more complex questions - problems longer to } \\
\text { resource. Get more calls from lower end users but they're } \\
\text { basically "no-brainers"" }\end{array}$ \\
\hline $\begin{array}{l}\text { Org } 2 \text { (large } \\
\text { other, medium } \\
\text { effectiveness) }\end{array}$ & Medium & $\begin{array}{l}1 / 2 \text { novice, } 1 / 2 \\
\text { expert }\end{array}$ & $\begin{array}{l}\text { M: "Novice and expert" } \\
\text { M: "We tend to spoon feed users; we get a lot of calls and } \\
\text { it's not because of a lack of training." }\end{array}$ \\
\hline $\begin{array}{l}\text { Org } 3 \text { (medium } \\
\text { other, high } \\
\text { effectiveness) }\end{array}$ & Medium & $\begin{array}{l}\text { Large variety, } \\
\text { fairly high skill } \\
\text { set, } 60 \% \\
\text { intermediate }\end{array}$ & $\begin{array}{l}\text { S: "Don't deal with midrange users a whole lot, see novice } \\
\text { and power users a lot" } \\
\text { S: "Novice is a quick fix while power users take two } \\
\text { weeks" } \\
\text { S: "Little knowledge is dangerous when it comes to users" } \\
\text { S: "Deal mostly with those who have a little knowledge } \\
\text { and do things that they shouldn't" }\end{array}$ \\
\hline $\begin{array}{l}\text { Org } 4 \text { (large } \\
\text { government, low } \\
\text { effectiveness) }\end{array}$ & High & $\begin{array}{l}\text { Variety } \\
80 \% \text { novice }\end{array}$ & $\begin{array}{l}\text { M: "Novices: shorter calls but more of them. Power users: } \\
\text { longer calls but fewer." } \\
\text { M: "Power users are pushing for us to provide more tools } \\
\text { for them, dig them out of holes, but we deal with both } \\
\text { [users and experts] equally." } \\
\text { S: "Power users cause more problems, don't realize big } \\
\text { picture" }\end{array}$ \\
\hline
\end{tabular}




\begin{tabular}{|c|c|c|c|}
\hline Organization & $\begin{array}{l}\mathrm{IT} \\
\text { Familiarity }\end{array}$ & $\begin{array}{l}\text { Level of Users } \\
\text { (Opinion of } \\
\text { Managers and } \\
\text { Support } \\
\text { Personnel) } \\
\end{array}$ & $\begin{array}{l}\text { Who Requires More Support? } \\
\text { M: Manager } \\
\text { S: Support Personnel }\end{array}$ \\
\hline $\begin{array}{l}\text { Org } 5 \text { (medium } \\
\text { government, } \\
\text { medium } \\
\text { effectiveness) }\end{array}$ & Low & $\begin{array}{l}\text { Variety, mostly } \\
\text { novice. }\end{array}$ & $\begin{array}{l}\text { S: "Deal more with people with average skills; easier to } \\
\text { help power users over phone, average users tend to have to } \\
\text { lead by hand" }\end{array}$ \\
\hline $\begin{array}{l}\text { Org } 6 \text { (low } \\
\text { government, low } \\
\text { effectiveness) }\end{array}$ & High & Full range & $\begin{array}{l}\text { M: "Power users harder but less calls. Novice users easier } \\
\text { but more calls." } \\
\text { M: "People in middle [require the most support because] } \\
\text { know enough to be dangerous." } \\
\text { S: "Know a little bit (most annoying, get themselves into } \\
\text { trouble); don't know but are willing to learn; know and } \\
\text { want to argue" } \\
\text { S: "Get mix of service versus complaint calls (50-50). } \\
\text { Little knowledge (whiners), know nothing (call often)" }\end{array}$ \\
\hline $\begin{array}{l}\text { Org } 7 \text { (small } \\
\text { other, high } \\
\text { effectiveness) }\end{array}$ & Low & $\begin{array}{l}\text { Varied, mostly } \\
\text { novice "Rely on } \\
\text { IT too much" }\end{array}$ & $\begin{array}{l}\text { S: "Usually deal with novices (people who don't know how } \\
\text { to use a program)" }\end{array}$ \\
\hline $\begin{array}{l}\text { Org } 8 \text { (medium } \\
\text { government, } \\
\text { medium } \\
\text { effectiveness) } \\
\end{array}$ & Medium & $\begin{array}{l}\text { Range, } 95 \% \\
\text { comfortable } \\
\text { with basics }\end{array}$ & S: "Not power users at all. Not that much hand holding" \\
\hline $\begin{array}{l}\text { Org } 9 \text { (medium } \\
\text { government, high } \\
\text { effectiveness) }\end{array}$ & High & $\begin{array}{l}\text { Most novice or } \\
\text { intermediate, } \\
\text { few power users } \\
\text { "Novice to } \\
\text { intermediate, a } \\
\text { few power } \\
\text { users, generally } \\
\text { friendly" } \\
\text { "Novices are } \\
\text { majority" }\end{array}$ & $\begin{array}{l}\text { S: "Same amount with each" } \\
\text { S: "Deal more with novices" }\end{array}$ \\
\hline $\begin{array}{l}\text { Org } 10 \text { (large } \\
\text { private, low } \\
\text { effectiveness) }\end{array}$ & High & $\begin{array}{l}\text { Variety, } \\
\text { majority } \\
\text { novice- } \\
\text { intermediate } \\
\end{array}$ & S: "1/2 novice, $1 / 2$ expert" \\
\hline $\begin{array}{l}\text { Org } 11 \text { (small } \\
\text { private, high } \\
\text { effectiveness) }\end{array}$ & Low & $\begin{array}{l}\text { Mostly novice, } \\
0 \text { expert }\end{array}$ & \\
\hline $\begin{array}{l}\text { Org } 12 \text { (large } \\
\text { private, low } \\
\text { effectiveness) }\end{array}$ & Medium & $\begin{array}{l}\text { Big variety } \\
\text { (mostly novice- } \\
\text { medium level) }\end{array}$ & $\begin{array}{l}\text { M: "Medium level are easier to deal with as can use } \\
\text { technical terms but less trouble than hackers." } \\
\text { S: "More time with novices" } \\
\text { S: "Hard to say which type is more difficult to deal with" }\end{array}$ \\
\hline
\end{tabular}

Table 51: End User Computer Skill Level 
Based on the significant relationship between $\Gamma$ familiarity and support effectiveness as well as taking guidance from organization \#9 who is an exception to the rule (see previous pages for discussion), it is hypothesized that the higher the end users' skill level, the lower the effectiveness of the support function unless the needs of advanced users are addressed and their expectations managed. IS managers should look at modifying their support offering to cater to both advanced users and novice users.

Some additional suggestions for services that would appeal to advanced users include:

- Obtaining feedback from the user community regarding the types of products, and services, and training they are interested in.

- Offering advanced training or special seminars on specific topics (e.g., Windows 2000, Access).

- Provide on-line information support tools (e.g., problem solving database) where advanced users can have access to detailed information to try and solve certain problems themselves.

\subsubsection{Type of support required}

On average, users reported contacting the IS department for support once a month or a few times a month (see Table 52). It appeared that low effectiveness organizations tended to contact support more often but this difference was not statistically significant based on the quantitative survey results 


\begin{tabular}{|l|c|l|l|l|}
\hline \multicolumn{1}{|c|}{ Support Frequency } & $\begin{array}{c}\text { \# of } \\
\text { Organizations }^{51}\end{array}$ & \multicolumn{1}{c|}{ Size } & \multicolumn{1}{c|}{ Type } & Effectiveness \\
\hline $\begin{array}{l}\text { Contacts Support Staff } \\
\text { Once a Month }\end{array}$ & 5 & $\begin{array}{l}\text { 2 small } \\
\text { 2 medium } \\
\text { 1 large }\end{array}$ & $\begin{array}{l}\text { 3 other } \\
\text { 2 government }\end{array}$ & $\begin{array}{l}\text { 2 high } \\
3 \text { medium }\end{array}$ \\
\hline $\begin{array}{l}\text { Contacts Support Staff a } \\
\text { Few Times a Month }\end{array}$ & 7 & $\begin{array}{l}\text { 1 small } \\
\text { 2 medium } \\
\text { 4 large }\end{array}$ & $\begin{array}{l}\text { 1 other } \\
\text { 3 government } \\
\text { 3 private }\end{array}$ & $\begin{array}{l}\text { 2 high } \\
\text { 1 medium } \\
\text { 4 low }\end{array}$ \\
\hline
\end{tabular}

Table 52: IS Support Call Frequency

The following are positive reasons why IS support could be contacted less often:

- No new systems were introduced recently

- People were at ease using the computers and familiar with the environment

- Everything (hardware, software, networking) was working and stable

- Standardized platform

Examples of negative reasons why IS support could be contacted less often are:

- People did not know who to contact

- People got help from their co-workers instead of IS (see section 4.7.1.5)

- People had a bad experience and did not want to contact the IS support function

Managers were asked why their users required support. The primary responses were:

- Bugs or problems with system, application, installation, etc.

- User knowledge issues.

${ }^{51}$ Mutually exclusive 
The user knowledge issues revolved around users asking "how-to" perform certain functions, getting into problems because of lack of knowledge/training, and applications not working as they expected. Table 53 outlines the breakdown of how much support was provided due to user knowledge issues versus system issues as well as comments from managers. 


\begin{tabular}{|c|c|c|c|}
\hline Organization & $\begin{array}{c}\text { \% User } \\
\text { Knowledge }\end{array}$ & $\begin{array}{l}\text { \% System } \\
\text { Problems / } \\
\text { Bugs }\end{array}$ & Comments \\
\hline $\begin{array}{l}\text { Org } 1 \text { (small, other, } \\
\text { medium } \\
\text { effectiveness) }\end{array}$ & $50 \%$ & $50 \%$ & $\begin{array}{l}\text { "A lot of the calls we receive are training issues." } \\
\text { "Support calls increased during the transition period; the } \\
\text { call volume never went down afterwards. More } \\
\text { complicated technology, more support." } \\
\text { "(1) System unavailable; (2) not knowing how to use the } \\
\text { application properly; (3) not behaving the way they } \\
\text { thought. Numbers evenly distributed among these } \\
\text { categories" }\end{array}$ \\
\hline $\begin{array}{l}\text { Org } 2 \text { (large other, } \\
\text { medium } \\
\text { effectiveness) }\end{array}$ & $25 \%$ & $75 \%$ & $\begin{array}{l}\text { "Problems due to complex environment. High volume of } \\
\text { calls: either things break a lot or the users are spoilt. } \\
\text { People can become more independent when they're left on } \\
\text { their own to extent. The high number of calls seems to be } \\
\text { from lack of interest in solving own problems." }\end{array}$ \\
\hline $\begin{array}{l}\text { Org } 4 \text { (large } \\
\text { government, low } \\
\text { effectiveness) }\end{array}$ & \multicolumn{3}{|c|}{ Combination of learning and system problems } \\
\hline $\begin{array}{l}\text { Org } 5 \text { (medium } \\
\text { government, medium } \\
\text { effectiveness) }\end{array}$ & Primarily & & $\begin{array}{l}\text { "Normally something new that they've never done before } \\
\text { or got into problems because of lack of knowledge." }\end{array}$ \\
\hline $\begin{array}{l}\text { Org } 6 \text { (low } \\
\text { government, low } \\
\text { effectiveness) }\end{array}$ & \multicolumn{3}{|c|}{ Combination of "how-to's"', problem resolution, and new installations. } \\
\hline $\begin{array}{l}\text { Org } 7 \text { (small other, } \\
\text { high effectiveness) }\end{array}$ & $45 \%$ & $55 \%$ & \\
\hline $\begin{array}{l}\text { Org } 8 \text { (medium } \\
\text { government, medium } \\
\text { effectiveness) }\end{array}$ & $33 \%$ & $67 \%$ & $\begin{array}{l}\text { "Combination of lack of knowledge and systems } \\
\text { problems. Currently in transition period to standardize } \\
\text { environment." }\end{array}$ \\
\hline $\begin{array}{l}\text { Org } 9 \text { (medium } \\
\text { government, high } \\
\text { effectiveness) }\end{array}$ & \multicolumn{3}{|c|}{ Combination of "how-to", things not working as normal, and system outages. } \\
\hline $\begin{array}{l}\text { Org } 11 \text { (small } \\
\text { private, high } \\
\text { effectiveness) }\end{array}$ & \multicolumn{3}{|c|}{ Mostly operating system / hardware-related } \\
\hline
\end{tabular}

\section{Table 53: Type of Support Required}

A direct relationship between type of support required by the end users and computer support effectiveness was not found. 


\subsubsection{Training}

User training was investigated for links to computer support effectiveness. According to reports from the interviewed managers, training was either provided by the IS department, a training department, the user community, outsourced, or a combination. Three organizations, all small or medium, did not outsource any of their training. The presence of a separate training department was more likely in large organizations due to the higher number of users to be trained.

Support effectiveness was lower when IS was not one of the group(s) who performed user training. This could indicate that the training was not aligned with the users' needs. The IS department knew why users contacted them for assistance but this information was not addressed in the training material. Conversely, support personnel may not have been aware of what the users learned during the training sessions and underestimated their ability when trying to assist them. In either case, it is important for the users' needs, training department, and IS department to be closely aligned and working towards the same objectives to be effective.

The following table categorizes the organizations and effectiveness ratings by user training provider. 


\begin{tabular}{|l|c|l|l|l|}
\hline \multicolumn{1}{|c|}{$\begin{array}{c}\text { Who Performs User } \\
\text { Training }\end{array}$} & $\begin{array}{c}\text { \# of } \\
\text { Organization }\end{array}$ & \multicolumn{1}{|c|}{ Size } & \multicolumn{1}{|c|}{ Type } & Effectiveness \\
\hline IS Department & 2 & $\begin{array}{l}1 \text { small } \\
1 \text { medium }\end{array}$ & $\begin{array}{l}1 \text { private } \\
1 \text { government }\end{array}$ & 2 high \\
\hline Training section & 1 & 1 small & 1 other & 1 medium \\
\hline $\begin{array}{l}\text { Combination IS and } \\
\text { outsourcing }\end{array}$ & 4 & $\begin{array}{l}2 \text { medium } \\
2 \text { large }\end{array}$ & $\begin{array}{l}1 \text { other } \\
1 \text { private } \\
2 \text { government }\end{array}$ & $\begin{array}{l}3 \text { medium } \\
1 \text { low }\end{array}$ \\
\hline $\begin{array}{l}\text { Combination IS, } \\
\text { outsourcing, and user } \\
\text { community }\end{array}$ & 2 & $\begin{array}{l}1 \text { small } \\
1 \text { medium }\end{array}$ & 2 other & 2 high \\
\hline $\begin{array}{l}\text { Training section and } \\
\text { outsourcing }\end{array}$ & 3 & 3 large & $\begin{array}{l}1 \text { private } \\
2 \text { government }\end{array}$ & 3 low \\
\hline
\end{tabular}

Table 54: User Training

All organizations but one reported that the IS department was involved in providing some level of feedback or recommendations on the type of user training required.

"We do orientation sessions for IT staff and users before rollouts of new tech. Application Development does own training for its applications while another $\mathrm{T}$ group does training for standards and products." (Manager, org \#2, large other, medium effectiveness)

"IT tailors what they want taught; official training provided outside company." "User support center provides information sessions on new technology. IT does basic instructions and contracts out advanced functions." (Manager, org \#3, medium other, high effectiveness)

"It is difficult to get users into training: they feel they don't need it or can't spare time. Training is determined based on changes to the environment (IT)." (Manager, org \#6, large government, low effectiveness)

${ }^{52}$ Mutually exclusive 
"We provided training on all environment. It is hard to schedule training. Because of environment, we will never have fully trained users. There is a high turnover of users." (Manager, org \#9, medium government, high effectiveness)

"There is the level of knowledge there to get product out. There is not a lot of company turnover. The IS initiative trains keeners who disseminate information." (Manager, org \#11, small private, high effectiveness)

Several people mentioned it was difficult to get people into training because the users could not spare the time. Should IS management look at ways to try to get the users into more training to reduce their needs for computer support? Managers were asked if they felt that more training provided to end-users would decrease the amount of support they required: five organizations agreed, three organizations disagreed, and three had mixed answers. On the whole, large and private organizations felt that more training resulted in less support. The interesting note is that on medium or highly effective organizations felt that more training would not result in less support. The following table displays the number and type of organizations concerning the relationship between the quantity of user training and support. 


\begin{tabular}{|l|c|l|l|l|}
\hline \multicolumn{1}{|c|}{$\begin{array}{c}\text { More Training, Less } \\
\text { Support? }\end{array}$} & $\begin{array}{c}\text { \# of } \\
\text { Organizations }\end{array}$ & \multicolumn{1}{c|}{ Size } & \multicolumn{1}{c|}{ Type } & Effectiveness \\
\hline Yes & $\begin{array}{c}5 \\
\text { (org \# 3,6,7, } \\
10,12)\end{array}$ & $\begin{array}{l}1 \text { small } \\
1 \text { medium } \\
3 \text { large }\end{array}$ & $\begin{array}{l}2 \text { other } \\
2 \text { private } \\
1 \text { government }\end{array}$ & $\begin{array}{l}3 \text { low } \\
2 \text { high }\end{array}$ \\
\hline No & $\begin{array}{c}1 \text { small } \\
\text { (org \#1,5,9 }\end{array}$ & $\begin{array}{l}1 \text { other } \\
2 \text { medium } \\
2 \text { government }\end{array}$ & $\begin{array}{l}2 \text { medium } \\
1 \text { high }\end{array}$ \\
\hline $\begin{array}{l}\text { Yes / No (mixed response } \\
\text { from respondents) }\end{array}$ & $\begin{array}{c}1 \text { medium } \\
\text { (org \# 2,4,8 }\end{array}$ & $\begin{array}{l}1 \text { other } \\
2 \text { government }\end{array}$ & $\begin{array}{l}1 \text { low } \\
2 \text { medium }\end{array}$ \\
\hline No Answer Provided & 1 & 1 small & 1private & 1 high \\
\hline
\end{tabular}

Table 55: Training - Support Relationship

More training would not result in less support because: (1) users would forget what they learned if they did not use it right away and (2) the more users learn, the more use they would make of the applications resulting in a higher probability of complex support issues.

"Users forget what they have learned - if they don't use it, they lose it." "I don't think there's a direct correlation between training and support. The more complex the technology, the more issues that come about." "Intermittent use of systems so users forget what they knew." (Manager, org \#1, small other, medium effectiveness).

"I think the more they know, the more apt they are to get into trouble." (Manager, org \#5, medium government, medium effectiveness)

"Sometimes users forget things they don't use that often." "Different types of support, more advanced problems." (Manager, org \#4, large government, low effectiveness)

One organization reported that their users found it easier to call IS for support than figure things out for themselves. Due to this, the amount of training would not make a difference. 
"We have done an awful lot of training of users. I think people have got in the habit of phoning and asking questions because it's easier. It's probably two things: a product of our success and a complex environment." (Manager, org \#2, large other, medium effectiveness)

In additional to formal training, support personnel were asked if they spent any time teaching users new skills/information as part of their day-to-day support tasks (see Table 56). In five organizations, all of the support staff tried to take time to teach users new things. All of the private organizations were unanimous in their participation of teaching new skills. In the remaining seven organizations, there was a mixture of responses from the support personnel. There was not a single organization where all support personnel reported never teaching users new skills.

"Teaching more one on one than classroom. I try and instruct users on how to get around problem and why it occurred. If it gets too technical their eyes tend to glaze over." (Support personnel, org \#5,medium government, medium effectiveness)

"I ask a lot of questions to users and tell them better ways of doing things. Users very appreciative of recommendations." (Support personnel, org \#10, large private, low effectiveness)

"Yes [teach new skills] because I hate being called back for the same thing over and over again" (Support personnel, org \#8, large government, low effectiveness)

One support person responded that they used to try and teach new skills but found that it did not help due to the complexity of the subject matter.

"No. Used to educate them as to what the changes are from the network perspective but most of the time they couldn't understand it" (Support personnel, org \#9, medium government, high effectiveness) 
The following table displays in which organizations support personnel teach users new skills as part of their support practices.

\begin{tabular}{|l|c|l|l|l|}
\hline Teach Users New Skills & \multicolumn{1}{|c|}{$\begin{array}{c}\text { \# of } \\
\text { Organizations }\end{array}$} & \multicolumn{1}{|c|}{ Type } & Effectiveness \\
\hline Yes & 5 & $\begin{array}{l}2 \text { small } \\
3 \text { large }\end{array}$ & $\begin{array}{l}\text { 1 other } \\
1 \text { government } \\
3 \text { private }\end{array}$ & $\begin{array}{l}2 \text { high } \\
3 \text { low }\end{array}$ \\
\hline Yes / No & 7 & $\begin{array}{l}\text { 1 small } \\
4 \text { medium } \\
\text { 2 large }\end{array}$ & $\begin{array}{l}\text { 3 other } \\
4 \text { government }\end{array}$ & $\begin{array}{l}\text { 2 high } \\
4 \text { medium } \\
1 \text { low }\end{array}$ \\
\hline
\end{tabular}

Table 56: Teaching Users New Skills

Although a great number of support personnel tried to teach users new skills, respondents in six organizations felt that it was very difficult due to the lack of time.

"Not that much time. I mostly [teach users] when I go to fix a problem. You explain as you go. It stops having to come the next time when doing the same thing." (Support personnel, org \#1, small other, medium effectiveness)

"It is not my job to training them. It takes a lot of time from us to teach them how to do things. If it's something that you need only a few minutes then I will do it. But it depends on the person and if they understand." (Support personnel, org \#8, medium government, medium effectiveness)

These organizations tended to be large organizations with either medium or low effectiveness ratings as displayed in the following table.

${ }^{53}$ Mutually exclusive 


\begin{tabular}{|l|c|l|l|l|}
\hline $\begin{array}{l}\text { Issues Trying to Teach } \\
\text { Users New Skills }\end{array}$ & $\begin{array}{c}\text { \# of } \\
\text { Organizations }\end{array}$ & Size & Type & Effectiveness \\
\hline Not Enough Time & 6 & $\begin{array}{l}1 \text { small } \\
1 \text { medium } \\
4 \text { large }\end{array}$ & $\begin{array}{l}\text { 2 other } \\
3 \text { government } \\
1 \text { private }\end{array}$ & $\begin{array}{l}3 \text { medium } \\
3 \text { low }\end{array}$ \\
\hline
\end{tabular}

Table 57: Time Issues with Teaching Users

Time constraints hindered the ability for support personnel to teach new skills. The time resource issue is examined in section 4.8.1.4.

All of the organizations provided or facilitated training for their end users. In future studies, end users should be surveyed to determine if they found the provided training to be sufficient and at the proper level.

IS departments in all organizations were involved in the user training process in one form or another. There was not enough information provided in this study to create a solid hypothesis on the relationship of user training to support effectiveness since a measure was not taken on the level of involvement in the organizations. Based on comments provided by various participants, a potential hypothesis for future investigation would be that the level of IS involvement in the user training process has a positive relationship with computer support effectiveness. IS managers should work with the user departments and training departments to determine their level of involvement, including:

- Supplying recommendations for training based on the types of calls received on the help desk and problems being worked. 
- Providing "train the trainer" sessions to the training department on new technologies and application rollouts

- Providing orientation sessions for users and the rest of IS department on new application rollouts or environment changes

- Create FAQs (frequently asked questions) help sheets to distribute to the user and training departments.

\subsubsection{Peer support}

Who do users contact when they have a computer-related problem? As discussed in the Organizational Structure chapter, users contacted the help desk, a central telephone number, or support personnel directly when they had a problem. Users were asked how often they contacted the IS department for support as well as how often they contacted their peers for support. In all of the organizations, people contacted the IS department the same amount or more then their peers. Private organizations, large organizations, and low effectiveness organizations tended to contact support staff more often than their peers as displayed in the following table. 


\begin{tabular}{|l|c|l|l|l|}
\hline \multicolumn{1}{|c|}{ Support Frequency } & \multicolumn{1}{c|}{$\begin{array}{c}\text { \# of } \\
\text { Organizations }\end{array}$} & \multicolumn{1}{c|}{ Size } & Type & Effectiveness \\
\hline $\begin{array}{l}\text { Users contact IS support } \\
\text { staff and peers the same }\end{array}$ & 5 & $\begin{array}{l}2 \text { small } \\
2 \text { medium } \\
1 \text { large }\end{array}$ & $\begin{array}{l}3 \text { other } \\
2 \text { government }\end{array}$ & $\begin{array}{l}2 \text { high } \\
3 \text { medium }\end{array}$ \\
\hline $\begin{array}{l}\text { Users contact IS support } \\
\text { staff more then peers }\end{array}$ & 7 & $\begin{array}{l}1 \text { small } \\
2 \text { medium } \\
\text { 4 large }\end{array}$ & $\begin{array}{l}\text { 1 other } \\
\text { 3 government } \\
\text { 3 private }\end{array}$ & $\begin{array}{l}\text { 2 high } \\
1 \text { medium } \\
\text { 4 low }\end{array}$ \\
\hline
\end{tabular}

Table 58: Frequency of IS and Peer Support

Seven organizations reported gaining greater user satisfaction from the support they received from the IS support staff than their peers, three organizations reported the opposite, with the remaining two organizations reporting the same level of satisfaction. The results are displayed in Table 59.

\begin{tabular}{|l|c|l|l|l|}
\hline Peer Support Satisfaction & \multicolumn{1}{|c|}{$\begin{array}{c}\text { \# of } \\
\text { Organizations }\end{array}$} & \multicolumn{1}{|c|}{ Size } & \multicolumn{1}{c|}{ Type } & Effectiveness \\
\hline $\begin{array}{l}\text { Same Satisfaction from } \\
\text { Support and Peers }\end{array}$ & 2 & 2 medium & $\begin{array}{l}\text { 1 other } \\
1 \text { government }\end{array}$ & $\begin{array}{l}1 \text { high } \\
1 \text { medium }\end{array}$ \\
\hline $\begin{array}{l}\text { Greater Satisfaction from } \\
\text { Support then Peers }\end{array}$ & 7 & $\begin{array}{l}2 \text { small } \\
\text { 2 medium } \\
\text { 3 large }\end{array}$ & $\begin{array}{l}2 \text { other } \\
\text { 3 government } \\
\text { 2 private }\end{array}$ & $\begin{array}{l}3 \text { high } \\
2 \text { medium } \\
2 \text { low }\end{array}$ \\
\hline $\begin{array}{l}\text { Greater Satisfaction from } \\
\text { Peers than Support }\end{array}$ & 3 & $\begin{array}{l}\text { 1 small } \\
\text { 2 large }\end{array}$ & $\begin{array}{l}\text { 1 other } \\
\text { 1 government } \\
\text { l private }\end{array}$ & $\begin{array}{l}1 \text { medium } \\
2 \text { low }\end{array}$ \\
\hline
\end{tabular}

Table 59: User Satisfaction with Peer Support

Based on these results, it is hypothesized that organizations where users obtain greater satisfaction from support received from their peers as opposed to support

\footnotetext{
${ }^{54}$ Mutually exclusive

${ }^{55}$ Mutually exclusive
} 
personnel experience lower levels of computer support effectiveness. The direction of this relationship is not known. Was IS support bad resulting in users being more satisfied with support from their peers? Or, was peer support so good that IS support paled in comparison? Users most likely expected better support from the IS department so even though support personnel and peers may have provided the same level of support, users would be more satisfied with the peer support as it was not part of their core job functions. More research is needed to examine this topic in more detail.

\subsubsection{Communication between IS and End Users}

Managers and support personnel were asked to rate the communication between the IS group and the end users. Seven organizations reported that the communication was good with the remaining five reporting some issues as displayed in the following table. All of the organizations with highly effective computer support reported good communication leading to the hypothesis that good communication between IS and end users results in better support effectiveness. 


\begin{tabular}{|c|c|c|c|c|}
\hline Communication & $\begin{array}{c}\# \text { of } \\
\text { Organizations }^{56}\end{array}$ & Size & Type & Effectiveness \\
\hline Good & 7 & $\begin{array}{l}2 \text { small } \\
3 \text { medium } \\
2 \text { large } \\
\end{array}$ & $\begin{array}{l}3 \text { other } \\
3 \text { government } \\
1 \text { private }\end{array}$ & $\begin{array}{l}3 \text { high } \\
3 \text { medium } \\
1 \text { low }\end{array}$ \\
\hline Some Issues & 5 & $\begin{array}{l}1 \text { small } \\
1 \text { medium } \\
3 \text { large }\end{array}$ & $\begin{array}{l}1 \text { other } \\
2 \text { government } \\
2 \text { private }\end{array}$ & $\begin{array}{l}2 \text { medium } \\
3 \text { low }\end{array}$ \\
\hline Definite Problem & 0 & N/A & N/A & N/A \\
\hline
\end{tabular}

Table 60: Communication between IS and End Users

To communicate effectively, support personnel must have the ability to interact well with the users and talk in their own language (i.e., translate from technical to business language).

"[Communication with the users] could be improved. The help desk could use communication skills training: listening and speaking. Informatics staff doesn't talk well to users in non-technical areas although we have user representatives in departments." (Org \#3, medium other, high effectiveness)

"[Communication with the users is] good generally since the restructure when this new guy came on board with people skills doing $1^{\text {st }}$ line support because the other guys are joe-techies. [Q: So one person can make a difference?] No doubt about it. All the difference in the world. If you can have everyone in the organization feeling comfortable with who's fixing their machine or doing what, it doesn't matter how bad that guy is screwing up. I sometimes feel that users expectations may be unrealistic." (Org \#1, small other, medium effectiveness)

Training or mentoring can be used to help support personnel with this skill or an alternative would be to have specific people or roles to assist in the user contact and communication function.

${ }^{56}$ Mutually exclusive 
"A new role is emerging, a business technologist, to advise business people on how to deploy technology. [We are trying to] formalize this new type of role." (Manager, org \#10, large private, low effectiveness)

Both users and support personnel must have a common understanding of each other roles and complexities.

“Techies and users don't understand each other as well as they should, users don't have good perspective of IT demands, educating users on IT issues not done (Org \#12, large private, low effectiveness)

"[Problem is getting] an understanding of other people's roles and them understanding ours." (Manager, org \#12, large private, low effectiveness)

"Good communication [between IT and the users]. We are seen as a different bunch, your typical techies. But other than that, users find IT approachable and will talk to us. You have the more difficult users who don't appreciate what's involved in development a system, especially with all the new products that you just slap together a screen and presto. They think things could go along faster." (Org \#1, small other, medium effectiveness)

When managers were asked what some of their main problems were when trying to deliver effective computer support, three end-user communication-related issues were indicated as displayed in Table 61. 


\begin{tabular}{|l|c|l|l|l|}
\hline $\begin{array}{l}\text { End User Issues reported } \\
\text { by Management }\end{array}$ & $\begin{array}{c}\text { \# of } \\
\text { Organizations }\end{array}$ & \multicolumn{1}{|c|}{ Size } & \multicolumn{1}{|c|}{ Type } & Effectiveness \\
\hline $\begin{array}{l}\text { Ability to properly manage } \\
\text { users expectations and } \\
\text { demands }\end{array}$ & 7 & $\begin{array}{l}2 \text { small } \\
4 \text { medium } \\
1 \text { large }\end{array}$ & $\begin{array}{l}4 \text { other } \\
3 \text { government }\end{array}$ & $\begin{array}{l}3 \text { high } \\
4 \text { medium }\end{array}$ \\
\hline $\begin{array}{l}\text { Users not understanding } \\
\text { costs/complexity or seeing } \\
\text { benefits of technology } \\
\text { and/or IT }\end{array}$ & 2 & $\begin{array}{l}1 \text { medium } \\
2 \text { large }\end{array}$ & $\begin{array}{l}1 \text { other } \\
1 \text { government } \\
1 \text { private }\end{array}$ & $\begin{array}{l}1 \text { high } \\
2 \text { low }\end{array}$ \\
\hline $\begin{array}{l}\text { Trying to understand user } \\
\text { requirements and needs }\end{array}$ & 2 & $\begin{array}{l}1 \text { small } \\
2 \text { large }\end{array}$ & $\begin{array}{l}\text { 2 other } \\
1 \text { private }\end{array}$ & $\begin{array}{l}2 \text { medium } \\
1 \text { low }\end{array}$ \\
\hline
\end{tabular}

\section{Table 61: End User Communication Issues}

A common communication issue that emerged was how to ensure that the users' have realistic expectations on what can be provided by the IS department. A few organizations admitted to spoon-feeding their users. The result was a higher frequency of support calls increasing the demands on the support function. One person stated that it was "providing Cadillac service for Chevrolet prices" (Manager, org \# 2, large other, medium effectiveness)

"Managing the expectations level of users is difficult. They think they can get everything right away, get whatever they want, and it will solve all their problems." (Manager, org \#5, medium government, medium effectiveness)

Another more common scenario for unrealistic expectations is that users do not understand the complexity of the IS function. Some users feel that if they can do a certain thing on their home PC, or see something new in Future Shop or PC Magazine, that it

${ }^{57}$ Not mutually exclusive 
should already be installed on their work machine. One person felt they were "competing with ads and newspapers. Users have expectations generated by media." (Manager, org \#, small other, high effectiveness). Some users wanted the new technology fast while others are resistant to change. Business needs must be distinguished from the demand for the "latest and greatest" technology.

"The amount of technology that can be absorbed into the business that can help the company is not that great. "We should be one step behind" versus bleeding edge. We have a problem with users seeing the latest and greatest and wondering why they don't have it." (Manager, org \# 12, large private, low effectiveness)

"Users don't understand the complexity. Locked down systems are OK for naive users but expert users are not pleased." (Support personnel, org \#10, large private, low effectiveness).

"[IS] needs to prove to the clients that doing good things which are to their benefit. Clients are only looking at their departments needs. The user opinion is that it costs too much for support." (Manager, org \#4, large government, low effectiveness)

Management must relay realistic expectations to the users in terms of deadlines

and benefits for IS initiatives.

"[IS director] pushed management to agree to accept [standardization], which was fine. But what he gave them was false expectations in terms of deadlines. People were expecting this to be problem-free, overnight." (Manager, org \#8, medium government, medium effectiveness)

Management support must be available to work with the users and upper management to push required initiatives, relay realistic expectations, and put impacts in terms of business-related gains. Expectations must be formalized into plans agreed upon by all parties: management, users, and support personnel. 
"[It is necessary to] get everyone to agree on what the true problems are. Very often, users have a certain expectation but it might be based on something that is not applicable in this certain case - managing expectations." (Support personnel, org \#1, small other, medium effectiveness)

"We needed the person in the right position to manage expectations from upper management." (Manager, org \#8, medium government, medium effectiveness)

"[One issue is] keeping people happy with so many different demands (some unreasonable). We have tried to establish service standards, etc." (Manager, org \#2, large other, medium effectiveness)

A business-driven approach is more successful than a technological driven approach.

Success requires that technology requirements be put into business terms and linked back to business needs and benefits.

"[Communication with users] getting better. [IT] used to be island in itself; used to tell business what to do. Now turning around and more of a team approach, business driven. Changed when new VP IS came on board." (Org \#10, large private, low effectiveness)

"Marketing hype instead of business needs driving need for new equipment; everyone thinks they have their own needs but they can be met with a standard. [Solving] via IT steering committee where we get together and set priorities and deal with all IT issues." (Manager, org \#5, medium government, medium effectiveness)

The business approach must work both ways. Users must have a realistic understanding of the costs/benefits of what can be provided but IT must also have a firm understanding of the users' requirements and needs.

"[IS] getting in on the ground floor of business planning is still a struggle. The strategic consulting concept is till brand new. One of challenges is trying to get [the users] to work with us to discuss requirements... and having us [IS] understand what they need and them understand how we can provide it." (Manager, org \#2, large other, medium effectiveness) 
"Making sure you know exactly what the user wants and trying to get that from them without insulting them or making them feel completely out of the loop; you have some difficult users who don't appreciate what's involved in development a system, especially with all the new products that you just slap together a screen and presto. They think things could go along faster." (Support personnel, org \#1, small other, medium effectiveness)

Improvements in any of the above areas would improve the communication between IS and end users resulting in improved computer support effectiveness.

\subsubsection{Other End User Issues}

During the end user analysis, a few new areas emerged as possible impacts to computer support effectiveness. These areas should be investigated in further studies.

\subsection{IS Credibility}

This area was deemed to be extremely important with respect to the ability to provide effective computer support. One organization that they had a lack of credibility with their users in the past and this was something that they needed to overcome to be successful. Improvements with the perceived service quality only happened over time.

"[One past problem faced was] reestablishing credibility to do the job. [The department's image was] damaged by one major visible incident... To reestablish, we did projects in small chunks, delivered the product, and supported it effectively." (Manager, org \# 2, large other, medium effectiveness)

Some possible suggestions for managers in organizations who are trying to reestablish credibility in their IS department are:

- Organize joint sessions between IS and user representatives to determine what has worked in the past and what has not worked 
- Engage users throughout the lifecycle of new rollouts starting in the early planning stages.

- Obtain user commitment for the project.

- Setup multiple smaller milestones that can be measured and produce visible results

- Communicate when milestones met or not met and obtain feedback at the different stages.

- Meet your targets.

- Learn from your mistakes.

\subsection{User Morale}

Two organizations reported have issues with user morale that impacted their ability to provide effective computer support.

"Morale very bad at user level (due to layoffs). (Manager, org \#7, small other, high effectiveness)

"Track problems users are logging to see if there are training issues; moral of users - dysfunctional areas, no authority, overworked nothing they can do about it." (Support personnel, org \#3, medium other, high effectiveness)

\begin{tabular}{|l|c|l|l|l|}
\hline $\begin{array}{c}\text { End User Issues reported by } \\
\text { Management }\end{array}$ & $\begin{array}{c}\text { \# of } \\
\text { Organizations }\end{array}$ & \multicolumn{1}{|c|}{ Size } & Type & Effectiveness \\
\hline Problems with user morale & 2 & $\begin{array}{l}1 \text { small } \\
1 \text { medium }\end{array}$ & 2 other & 2 high \\
\hline
\end{tabular}

Table 62: End User Morale 


\subsubsection{Summary of End Users Hypotheses}

The following hypotheses were proposed regarding end users and computer support effectiveness. Hypotheses tagged 'NEW' were not validated based on the study's data but were evaluated to be worth further study based on a combination of interview comments and past research.

1. The higher the end users' skill level, the lower the effectiveness of the support function unless the needs of advanced users are addressed and their expectations managed.

2. Organizations where users obtain greater satisfaction from support received from their peers as opposed to support personnel experience lower levels of computer support effectiveness.

3. Good communication between IS and end users results in better support effectiveness.

4. NEW: The level of IS involvement in the user training process has a positive relationship with computer support effectiveness.

5. NEW: End user morale impacts the perceived computer support effectiveness.

6. NEW: End user view of the credibility of the IS department impacts the perceived computer support effectiveness. 


\subsection{Resources}

\subsubsection{Discussion}

Due to the high demand for computer support services, IS department frequently have prioritized tasks due to the limited resources. Both managers and support personnel were asked about the biggest resource-related issues that hindered their ability to provide effective support to examine the following question:

Research Question \#6: What is the impact of the availability of resources on the effectiveness of the computer support function?

The proposed theoretical model outlined the following areas as possible impacts to support effectiveness:

- $\quad$ Equipment / Products

- Personnel

- Money

- $\quad$ Time

Resource-related issues were reported in all of the above areas. Training / Development was also part of the proposed theoretical model and was discussed in section 4.6.1.4.

\subsubsection{Equipment/Products}

Four organizations reported problems obtaining the equipment required to perform their job. All of the organizations were either medium or large sized government 
organizations with medium or low effectiveness ratings. The following table displays the breakdown of the organization by category.

\begin{tabular}{|l|c|l|l|l|}
\hline $\begin{array}{c}\text { Resource Issues reported by } \\
\text { Management and Support }\end{array}$ & $\begin{array}{c}\text { \# of } \\
\text { Organizations }\end{array}$ & \multicolumn{1}{|c|}{ Size } & Type & Effectiveness \\
\hline $\begin{array}{l}\text { Do not have sufficient } \\
\text { equipment (hardware, software, } \\
\text { networking) - reported by } \\
\text { manager }\end{array}$ & $\begin{array}{c}2 \\
\text { (org \#6, 8) }\end{array}$ & $\begin{array}{l}1 \text { large } \\
1 \\
\text { medium }\end{array}$ & 2 government & $\begin{array}{l}1 \text { low } \\
1 \text { medium }\end{array}$ \\
\hline $\begin{array}{l}\text { Do not have sufficient } \\
\text { equipment (hardware, software, } \\
\text { networking) - reported by } \\
\text { support personnel }\end{array}$ & $\begin{array}{c}2 \\
\text { (org \# 4,5) }\end{array}$ & $\begin{array}{l}1 \text { large } \\
1 \\
\text { medium }\end{array}$ & 2 government & $\begin{array}{l}1 \text { low } \\
1 \text { medium }\end{array}$ \\
\hline No issues reported & $\begin{array}{c}8 \\
\text { (org \# 1,2,3,7, } \\
9,10,11,12)\end{array}$ & $\begin{array}{l}3 \text { large } \\
2 \\
\text { medium } \\
3 \text { small }\end{array}$ & $\begin{array}{l}\text { 1 government } \\
\text { 3 other }\end{array}$ & $\begin{array}{l}\text { 3 low } \\
2 \text { medium } \\
4 \text { high }\end{array}$ \\
\hline
\end{tabular}

\section{Table 63: Equipment / Product Resource Issues}

The most frequent reason provided for the equipment-related issues was the cumbersome government procurement process that impede IS' ability to bring in equipment quickly.

"Need more resources but management is doing their best to cope with it. It is a slow process to get more due to government procedures." (Support personnel, org \#5, medium government, medium effectiveness)

Four of the five government organizations reported equipment resource issues. It is hypothesized that government organizations have more problems obtaining the required equipment to provide computer support.

${ }^{58}$ Mutually exclusive 
Only medium and large sized organization reported equipment resource issues. It is hypothesized that there is a greater tendency for medium or large sized organizations to have problems obtaining the required equipment to provide computer support.

No equipment resource issues were reported in high support effectiveness organizations. It is hypothesized that equipment-related resource issues lead to decreased levels of support effectiveness.

IS managers need to find ways to procure the required equipment. Some possible suggestions are:

- Ensuring hardware, software, and networking expenditures outlined in technology plan and gaining pre-approval for purchasing

- Bulk purchasing

- Buying from list of approved vendors to eliminate some of the due process in procurement process

- Implementation of technology standards (see section 4.5.1.2.1) to reduce variety in amount of equipment required with possible purchase and storage of spare components

\subsubsection{Human Resources}

Three main types of human resources issues were discovered: lack of staff, difficulty in hiring, and imbalanced skill sets. Overall, ten of twelve organizations reported they did not have enough staff to perform their work. Of these ten organizations, 
managers and support personnel in four organizations agreed that there was an issue. In the remaining six organizations, managers felt there were staffing issues in half the organizations while support personnel thought there were issues in the other half as displayed in the following table. There did not appear to be a direct relationship between human resources issues and computer support effectiveness.

\begin{tabular}{|c|c|c|c|c|}
\hline $\begin{array}{l}\text { Resource Issues reported by } \\
\text { Management and Support }\end{array}$ & $\begin{array}{c}\text { \# of } \\
\text { Organizations }^{59} \\
\end{array}$ & Size & Type & Effectiveness \\
\hline $\begin{array}{l}\text { Do not have enough staff - } \\
\text { Reported by manager and } \\
\text { support personnel }\end{array}$ & $\begin{array}{c}4 \\
\text { (org \# } 3,8,10,12\end{array}$ & $\begin{array}{l}2 \\
\text { medium } \\
2 \text { large }\end{array}$ & $\begin{array}{l}1 \text { other } \\
1 \text { government } \\
2 \text { private }\end{array}$ & $\begin{array}{l}1 \text { high } \\
1 \text { medium } \\
2 \text { low }\end{array}$ \\
\hline $\begin{array}{l}\text { Do not have enough staff - } \\
\text { Reported by manager }\end{array}$ & $\begin{array}{c}3 \\
\text { (org\# } 4,7,11 \text { ) }\end{array}$ & $\begin{array}{l}2 \text { small } \\
1 \text { large }\end{array}$ & $\begin{array}{l}1 \text { other } \\
1 \text { government } \\
1 \text { private }\end{array}$ & $\begin{array}{l}2 \text { high - } \\
1 \text { low }\end{array}$ \\
\hline $\begin{array}{l}\text { Do not have enough staff - } \\
\text { Reported by support personnel }\end{array}$ & $\begin{array}{c}3 \\
\text { (org \#2,6,9) }\end{array}$ & $\begin{array}{l}1 \\
\text { medium } \\
2 \text { large }\end{array}$ & $\begin{array}{l}1 \text { other } \\
2 \text { government }\end{array}$ & $\begin{array}{l}1 \text { high } \\
1 \text { medium } \\
1 \text { low }\end{array}$ \\
\hline Have enough staff & $\begin{array}{c}2 \\
\text { (org \# } 1,5 \text { ) }\end{array}$ & $\begin{array}{l}1 \text { small } \\
1 \\
\text { medium }\end{array}$ & $\begin{array}{l}1 \text { other } \\
1 \text { government }\end{array}$ & 2 medium \\
\hline
\end{tabular}

Table 64: Lack of Staff

Lack of staff was a common issue and impacted all types of organizations as well as both high, medium, and low effectiveness organizations. All of the large organizations reported staffing issues most likely due to requiring more staff to support a larger user base resulting in a higher probability of issues.

${ }^{59}$ Mutually exclusive 
The two main results in inadequate staffing levels were lack of service and overtime. The first impacted the end users and the second impacted the support staff.

- Lack of Service

"Not enough staff to allow us to do what we really want to do or expand the way we want to. So we're sort of limited in what we can do because of the resources we have." (Support personnel, org \#2, large other, medium effectiveness)

"There are not enough people and resources to go out and see how things are going," (Manager, org \#3, medium other, high effectiveness)

"Nice to have extra bodies to be able to concentrate more on people." (Support personnel, org \#9, medium government, high effectiveness)

- Overtime

"We are lacking human resources and are burning out our people with overtime." (Manager, org \#8, medium government, medium effectiveness)

"Lack of human resources: people doubled up on projects." (Support personnel, org \#9, medium government, high effectiveness)

Several managers dealt with the staffing issues by either prioritizing the work that needed to get done and making the appropriate decisions on what service will be provided or not. Other managers were looking at reorganizing their departments to be more efficient in providing the services.

"Do not have enough staff today but with new reorganization, should have enough". (Manager, org \#4, large government, low effectiveness)

Some organizations looked at the services they provided and tried to determine how to make the support tasks easier to do. One popular method was to standardize the products 
and services offered to reduce the complexity of the support function. Please refer to section 4.5.1.2.1 for more details on this subject.

Should management hire more support staff if there are shortfalls? The answer depends on the nature of the understaffing. Many of the staffing shortfalls were due to technology transitions or concurrent projects underway causing additional burden on the support staff resulting in increased work levels that were cyclic in nature. The following table displays the organizations that had a technology transition or reorganization underway during the study timeframe.

\begin{tabular}{|l|c|l|l|l|}
\hline & \multicolumn{1}{|c|}{$\begin{array}{c}\text { \# of } \\
\text { Organizations }\end{array}$} & \multicolumn{1}{|c|}{ Type } & Effectiveness \\
\hline $\begin{array}{l}\text { Organizations where a transition } \\
\text { or reorganization was in progress }\end{array}$ & $\begin{array}{c}\text { (org \# } 1,2,4, \\
6,7,8)\end{array}$ & $\begin{array}{l}2 \text { small } \\
\text { medium } \\
3 \text { large }\end{array}$ & $\begin{array}{l}\text { 3 other } \\
3 \text { government }\end{array}$ & $\begin{array}{l}1 \text { high } \\
\text { 3 medium } \\
2 \text { low }\end{array}$ \\
\hline
\end{tabular}

"Not enough staff but not normal time with conversion." (Support personnel, org \#6, large government, low effectiveness)

"Enough resources. Comes in spurts so it's hard to manage. Think we have enough staff. It's hectic because in middle of transition but once it is done, should be a lot easier to handle clients." (Support personnel, org \#8, medium government, medium effectiveness)

There did not appear to be a relationship between organizations under transition/reorganization and effectiveness.

Staffing levels for the high points in the cycle could be handled by either using the current staff with a combination of overtime and reduced services in other areas. 
Alternatively, temporary staff can be used to aid in the project-related peaks. This decision should be made in consultation with the support team. Some members either do not mind the overtime and/or like to be involved in the projects as it provides them with new learning opportunities. Some support staff do not like to see the more "interesting" project work go to consultants while they perform their normal routine.

If the staffing issue is constant and not cyclic in nature, management should either reexamine the services the support department provides or hire the necessary level of staff to support the required level of service. If funding for the staffing was an issue, some organizations felt a "user pay" scenario could fund the level of service requested or constrain the scope. Please refer to section 4.8.1.3 for more discussion on this topic.

The following table summarizes the organizations reporting problems hiring reported staff or finding the required skill set.

\begin{tabular}{|l|c|l|l|l|}
\hline $\begin{array}{c}\text { Resource Issues reported by } \\
\text { Management and Support }\end{array}$ & $\begin{array}{c}\text { \# of } \\
\text { Organizations }\end{array}$ & \multicolumn{1}{|c|}{ Size } & \multicolumn{1}{|c|}{ Type } & Effectiveness \\
\hline Problems hiring required staff & $\begin{array}{c}3 \\
\text { (org \#2,6,8) }\end{array}$ & $\begin{array}{l}1 \\
\text { medium } \\
2 \text { large }\end{array}$ & $\begin{array}{l}\text { 1 other } \\
2 \text { government }\end{array}$ & $\begin{array}{l}2 \text { medium } \\
1 \text { low }\end{array}$ \\
\hline $\begin{array}{l}\text { Skill level of staff or lack of } \\
\text { specialists }\end{array}$ & $\begin{array}{l}4 \\
\text { (org \#2,8,9,12) }\end{array}$ & $\begin{array}{l}\text { medium } \\
\text { 2 large }\end{array}$ & $\begin{array}{l}\text { 1 other } \\
\text { 2 government } \\
\text { 1 private }\end{array}$ & $\begin{array}{l}\text { 1 high } \\
2 \text { medium } \\
1 \text { low }\end{array}$ \\
\hline
\end{tabular}

Table 65: Other Staffing Issues

${ }^{60}$ Not mutually exclusive 
Three organizations reported have problems hiring required staff. Some of the hiring issues revolved around the staffing policies (see section 4.5.1.1) whereas some concerned the ability to hire people with the correct skill set.

"Can find people with really good technical side but terrible with business side. [The organization] has routinely taken a programmer and made them a manager but programming has nothing to do with managing. If [staff] are lucky, they have a good mentor." (Manager, org \#12, large private, low effectiveness)

"Staffing is a huge issue. It is difficult to bring people in and good people are leaving." (Manager, org \#8, medium government, medium effectiveness)

Four organizations felt they had issues with the skill level complement of their staff. There were reports of not enough specialists. A skills gap would occur in the organization if a person with a very specialized skill set left.

"Not enough people with varied skills and not enough overlapping of skills. This could be an issue if someone leaves." (Support personnel, org \#8, medium government, medium effectiveness)

"Human resourcing is a problem. It is very hard to have one individual that knows all the products equally well at a guru level as we support a very wide range of products. We probably have enough human resources at a numbers level but skill level wise, it could always be improved." (Support personnel, org \#2, large other, medium effectiveness)

Each IS department should have a healthy mix of generalists and specialists as well as ensuring that there is backup for the specialists in case they are not available or leave.

Most of the organizations experienced issues with human resources including high effectiveness organizations. The question of how these issues were handled may be more appropriate in determining the link to effectiveness. 


\subsubsection{Money}

Managers in nine organizations reported money-related issues. The issues with budgets and funding were prevalent and experienced by all sizes and types of organizations. There was no direct relationship between funding issues and support effectiveness. The following table outlines the funding categories by organization.

\begin{tabular}{|l|c|l|l|l|}
\hline $\begin{array}{c}\text { Resource Issues Reported by } \\
\text { Management }\end{array}$ & $\begin{array}{c}\text { \# of } \\
\text { Organizations }^{61}\end{array}$ & \multicolumn{1}{|c|}{ Size } & \multicolumn{1}{|c|}{ Type } & Effectiveness \\
\hline $\begin{array}{l}\text { Decreasing budget or funding } \\
\text { issues/constraints }\end{array}$ & $\begin{array}{c}10 \\
\text { (org \# 1,3,4,6, } \\
7,8,9,10,11, \\
12)\end{array}$ & $\begin{array}{l}3 \text { small } \\
\text { medium } \\
4 \text { large }\end{array}$ & $\begin{array}{l}3 \text { other } \\
4 \text { government } \\
3 \text { private }\end{array}$ & $\begin{array}{l}4 \text { high } \\
2 \text { medium } \\
4 \text { low }\end{array}$ \\
\hline No issues reported & $\begin{array}{c}1 \\
\text { (org \# 2, 5) }\end{array}$ & $\begin{array}{l}1 \\
\text { medium } \\
1 \text { large }\end{array}$ & $\begin{array}{l}\text { 1 other } \\
1 \text { government }\end{array}$ & 2 medium \\
\hline
\end{tabular}

Table 66: Money Resource Issues

A manager in one organization felt that the budget planning process for new projects often ignored the funding required for support and maintenance activities after the projects went into production.

"Have money for a project until 6 months after the rollout." (Manager, org \#6, large government, low effectiveness)

A government-specific management issue was the inability to reward their staff for a job well done with monetary or cash-equivalent rewards. Managers felt this would help with the morale and motivation of the team.

\footnotetext{
${ }^{61}$ Mutually exclusive
} 
"We don't have discretionary budget to reward people. Our salaries are not good compared to the private sector." (Manager, org \#8, medium government, medium effectiveness)

Due to budget constraints and cuts, support organizations have been asked to do more with less and prioritize to fund only what is absolutely required.

"Across the board cuts - 'do more with less'" (Manager, org \#9, medium government, high effectiveness)

"We tend to do what we can with the resources we have. It is sometimes constraining but not significant. Due to budget constraints, the total headcount must remain the same. It is a matter of prioritizing" (Manager, org \#1, small other, medium effectiveness)

What should managers do to try and deal with this issue? One popular way to resolve the funding versus services issue was to look to a user pay or cost recovery mechanism. In this model, the users would dictate and pay for the type and level of services required.

"We work on a cost recovery basis. We provide basics at cost and extras cost more. Users don't want to pay for things that aren't broken right now." (Manager, org \#4, large government, low effectiveness)

"Balance between Cadillac service when they're [users] paying Chevrolet prices. [The users] are not really paying prices but that's part of it. If they were really being costed back to the bottom line, I think they would think twice." (Manager, org \#2, large other, medium effectiveness)

There are some difficulties with moving to a user pay model. It is easy for users to make decisions to pay for things where they can see tangible results. For example, a new piece of software installed on their desk or a faster machine with a larger monitor. It is more difficult for users to see the benefits of some behind-the-scenes work. For example, server maintenance or an Oracle database upgrade. 
"Cost recovery allows users to control services but depresses level of Informatics" (Manager, org \#4, large government, low effectiveness)

Some users felt that since they were paying, they should have their choice of equipment, software, etc. and did not feel that they should have to adhere to company standards resulting in higher support and maintenance costs. In one organization, combining user pay and standards could result in decreased levels of satisfaction with more advanced users as witnessed in the following organization.

"The funding issue is one of the greatest problems. It has grown to user pay but as user has less money, feels that things IT needs to put in are corporate things... Users don't have a choice as to what goes on their desktop." (Manager, org \#6, large government, low effectiveness)

A combination of IS funding and user pay may be warranted to maintain the middle ground and remove some funding issues while still maintaining control over technology direction and standards. IS could fund corporate-wide initiatives (software and hardware) as well as areas such as, infrastructure, networks, support and maintenance of common environments, and capacity planning. Users could fund software and hardware specific to their groups (desktop, servers, printers) along with a level of required support in the form of service level agreements (SLAs). Users would be required to operate within the ISdirected standards since IS is funding the base support and maintenance activities although users would fund any additional support required. Users did not always understand the complexity and the true costs of technology (see section 4.7.1.6). The key to any such initiative would be to ensure that both IS and the user groups have a common 
understanding of the services that will be provided as well as the costs and benefits. The use of a combination of IS funding and user pay should be investigated in future research.

\subsubsection{Time}

Both managers and support personnel in six organizations reported problems with lack of time. Support personnel in an additional three organizations also reported time constraints but managers in the same organizations did not. A relationship between time constraints and support effectiveness was not found since both high, medium, and low support effectiveness organizations reported issue with time constraints. The following table displays the breakdown of these organizations by time issue category.

\begin{tabular}{|l|c|l|l|l|}
\hline $\begin{array}{c}\text { Resource Issues reported by } \\
\text { Management and Support }\end{array}$ & $\begin{array}{c}\text { \# of } \\
\text { Organizations }\end{array}$ & \multicolumn{1}{|c|}{ Size } & Type & Effectiveness \\
\hline $\begin{array}{l}\text { Time constraints - Reported by } \\
\text { management and support } \\
\text { personnel }\end{array}$ & $\begin{array}{c}6 \\
\text { (org \# 2,3,4,7, } \\
8,10)\end{array}$ & $\begin{array}{l}1 \text { small } \\
2 \\
\text { medium } \\
3 \text { large }\end{array}$ & $\begin{array}{l}\text { 3 other } \\
2 \text { government } \\
1 \text { private }\end{array}$ & $\begin{array}{l}2 \text { high } \\
2 \text { medium } \\
2 \text { low }\end{array}$ \\
\hline $\begin{array}{l}\text { Time constraints - Reported by } \\
\text { support personnel only }\end{array}$ & 3 & $\begin{array}{l}2 \\
\text { medium } \\
\text { (org large }\end{array}$ & $3,6,9$ government & $\begin{array}{l}1 \text { high } \\
1 \text { medium } \\
1 \text { low }\end{array}$ \\
\hline No issues reported & $\begin{array}{l}2 \text { small } \\
1 \text { large }\end{array}$ & $\begin{array}{l}\text { 1 other } \\
2 \text { private }\end{array}$ & $\begin{array}{l}1 \text { high } \\
1 \text { medium } \\
1 \text { low }\end{array}$ \\
\hline
\end{tabular}

Table 67: Time Resource Issues

${ }^{62}$ Mutually exclusive 
The results of not having enough time to perform the required work were fixing problems as quickly as possible, operating in reactive mode, patching problems, and reducing or eliminating follow ups with users.

"They patch a lot here, sometimes it's because not enough time or don't have answer now. They don't seek enough to find answer." (Support personnel, org \#8, medium government, medium effectiveness)

One common way to try and deal with time constraints was through prioritization of issues. Prioritization is not necessarily an easy task due to the number of urgent issues at any given time. A few organizations reported having problems trying to prioritize due to lack of processes and problems with defining "high priority" problems (e.g., people who complain the loudest or most strategic impact). For example, the following organization reported difficulties trying to prioritize.

"It is difficult to prioritize what needs to get done. Lack of time to define processes, procedures, and determine root cause of problem" (Manager, org \#10, large private, low effectiveness)

Several organizations have been very successful in their use of prioritization that is often the only course of action when constrained by time and other resources.

"Prioritization of calls is important. You may be doing a call and get an emergency call. You need to know how to evaluate if it is truly an emergency since there is no time to spare." (Support personnel, org \#8, medium government, medium effectiveness)

"A lot of problems at one time. You prioritize them over time. Groups takes priority over individual. User support is also assigned to inventory when not busy." (Support personnel, org \#3, medium other, high effectiveness) 
"[We address the time issue by] prioritizing problems. You can get caught up on non-important, non-strategic, noisy projects that assume a lot of staff for a while with no long-term benefits." (Manager, org \#2, large other, medium effectiveness)

One organization was attempting the following initiatives to try and improve their ability to prioritize problems.

“(1) Development \& technical services prepared a requirements definition for software to help (call prioritization, statistics)... (2)Would like to see attempt to come up with traditional levels of support. [Creation of a dispatcher position as] the beauty of a dispatcher is the longer they stay in that job, the more problems they can solve because they become more familiar with them." (Manager, org \#1, small other, medium effectiveness)

Managers should look at proactive measures (see section 4.5.1.2.1) as well as develop prioritization levels and processes to help address time constraints. Any issues with prioritization must be resolved through proper definition and processes. The entire support team (personnel and management) must have a common understanding of the priorities as well as an escalation mechanism with management to resolve any questions so that the support personnel can make the best use of their time. Management must be available to provide support, if required, to manage the end users and their expectations in cases where the users' issues are not deemed to be high priority. As well, time management courses for managers and support personnel are recommended.

\subsubsection{Summary of Resources Hypotheses}

The following hypotheses were proposed regarding resources and computer support effectiveness. Hypotheses tagged 'NEW' were not validated based on the study's data 
but were evaluated to be worth further study based on a combination of interview comments and past research.

1. Government organizations have more problems obtaining the required equipment to provide computer support.

2. There is a greater tendency for medium or large sized organizations to have problems obtaining the required equipment to provide computer support.

3. Equipment-related resource issues lead to decreased levels of support effectiveness.

4. NEW: A combination of user pay and IS funded support results in increased support effectiveness.

5. NEW: Well-defined problem prioritization processes lead to increased support effectiveness. 


\section{CONCLUSIONS AND LIMITATIONS OF THE STUDY}

\subsection{Conclusions}

Organizations are dependent on the use of technology in today's business environment making the computer support function critical. Computer support is not an easy function to provide. All organizations are different and technology is always changing. Users' requirements within and between organizations differ. There is not one formula that can be used to specify how to provide effective support so this study has identified areas, factors, and issues with impacts to computer support effectiveness worth future investigation and analysis.

The proposed theoretical model tested in this study contained five independent variable groups each containing several independent variables. A relationship was found between computer support effectiveness and at least one independent variable (and generally more) in each of the major groups: organizational structure, management attitudes/practices, computer support personnel, end users, and resources. No new groups were found during the course of the study.

Revised diagrams are displayed in figures 3 and 4 outlining the findings of this study. These diagrams highlight the following:

- The independent variables found to impact computer support effectiveness. These variables are marked with a checkmark in the diagrams. 
- The independent variables found not to impact computer support effectiveness. These variables are marked with an ' $\mathrm{X}$ ' in the diagrams.

- The independent variables where it was not possible to determine the relationship to computer support effectiveness. This may have been due to insufficient differentiation between the participating organizations or not enough information to complete the analysis. These variables are marked with a '?' in the diagrams.

- New independent variables that are proposed to have a relationship to support effectiveness but require further testing. These variables are in italics in the diagrams. 


\section{Organicational Structure}

- public ( private / otherb

. size (user base) $\square$

. centralization / decentralization $\square$

. support department structure []

. rank of executive in charge of IS 0

. outsourcing $\mathbb{X}$

. close alignment of support and

application groups

\section{Management Attitudes / Practices}

Policies and planning

IT plan $\triangle$

. organizational polic ies

Management practices

. reactive/proactive support [

technology standards that mest

user's expectations and nesd's

. usar involvament (user

commitment)

- preventativs maintenan ce and

system monitoring

service orientation $\square$

hining practices $ه$

- measure ment of success $\square$

- problem monitoring methodology $\square$

direction (future vision) 因

. competence $\square$

Communication

IS and upper management $\square$

. IS departments $\square$

\section{Independent Variables}

Effectiveness of the Support Function . service quality . user satisfaction

Dependent Variable

Legend

Supported 8

Not Supported $囚$

Unable to Detemine

Mew variable for investigation

Figure 3: Organizational Structure \& Management Practices Findings 

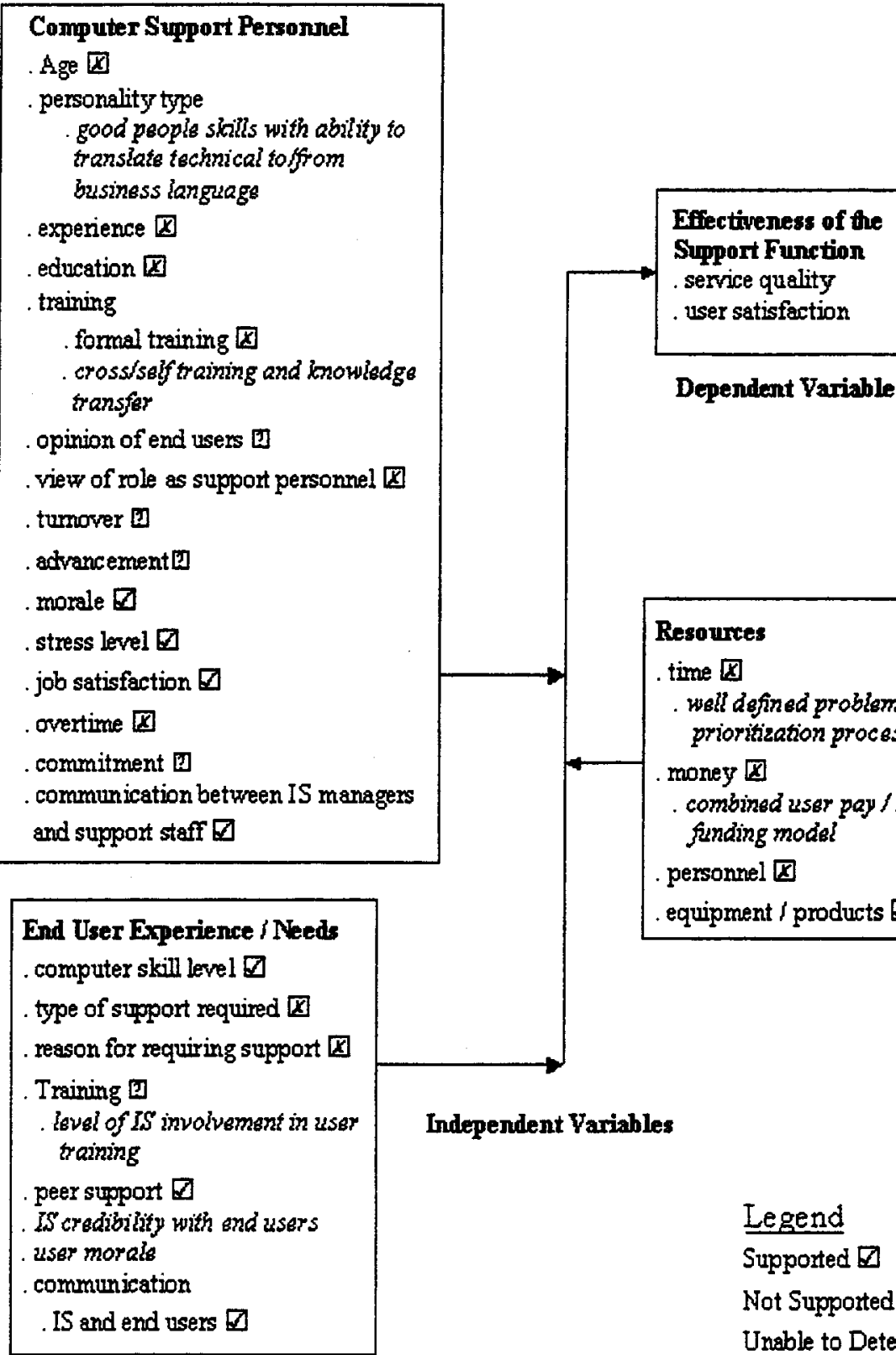

\section{Resources}

time . well defined problem prioritization processes money . combinsd usar pay / IS funding modid personnel $\mathbb{\theta}$ equipment / products $\square$

Figure 4: Support Personnel, End Users \& Resources Findings 
Based on the study's findings, there are several recommendations for managers on how to improve computer support in their organizations. All recommendations are detailed in Chapter 4 under the relevant independent variable group discussion (e.g., organizational structure, management attitudes/practices). The top recommendations for managers follow. The first recommendation is to hire support staff with strong people skills and spending time educating staff on the business side of users' jobs. It is much easier to communicate and understand impacts and priorities when the support personnel and users understand each other.

Another recommendation is to define support needs and requirements in terms of direct business gains (e.g., turnaround time) to assist in achieving buy-in from upper management and users. Any proposals should be linked to technical implementation plans with measurable milestones for IT and upper management reporting and should be signed off by both IS and users before proceeding. This secures user involvement and commitment in the deliverables as well as highlighting the progress.

Since lack of time, funding, and human resources are common occurrences with respect to computer support, managers should invest time in implementing formal problem prioritization processes to ensure that everyone including management, computer support personnel, and the users have a common understanding of what problems will be addressed in what order. This in combination with setting realistic expectations with the users and upper management will ensure that support staff do not 
get overwhelmed with too many issues at once and are able to concentrate on the important problems at hand.

Based on this study's findings, a revised overall model for computer support effectiveness was created highlighting the supported independent variables, the new proposed independent variables, and the relationships between them. The new model is displayed in Figure 5. This model provides a base for future research of the variables impacting computer support effectiveness. It also acts as a roadmap for IS managers stressing areas of investigation for improving computer support operations and effectiveness. 


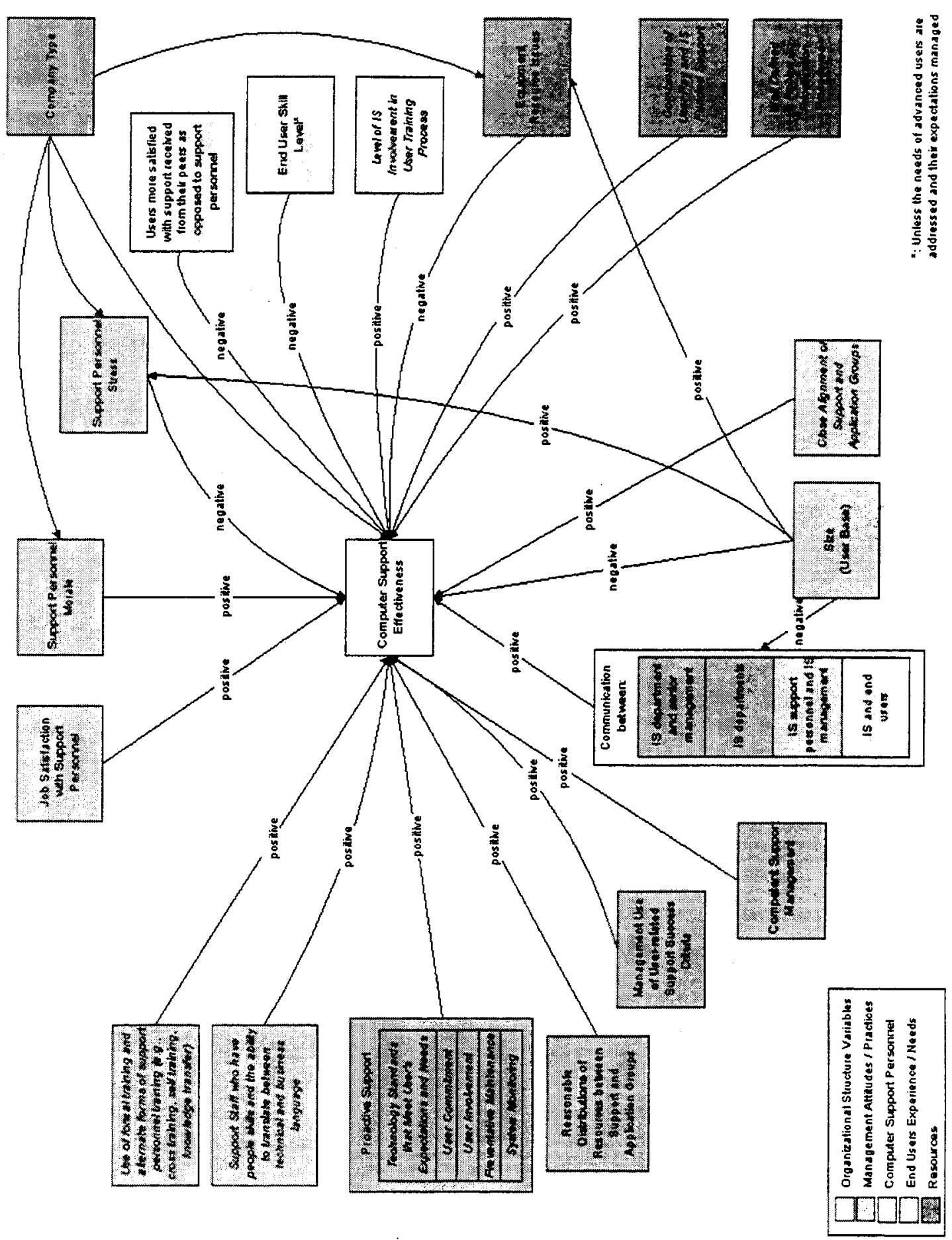

Figure 5: Revised Theoretical Model 


\subsection{Generalizability}

Generalizability of the results of this study is limited to similar firms (e.g., financial companies, government departments). The results cannot be generalized to high-tech or manufacturing companies that may use computers for different purposes. Only a few firms located in the same geographical location were studied limiting the generalizability of the results and restricting the amount of statistical analysis that can be done. This was deemed necessary to fully examine the topic area from an exploratory point of view to provide recommendations for future research.

\subsection{Limitations}

There are some major limitations of this study. First, the participating organizations were selected using a convenience sample. Twelve of sixty-five organizations approached agreed to participate in the study. The possibility exists that organizations with poor computer support departments chose not to participate in the study especially since all participating organizations received computer support effectiveness ratings greater than or equal to Neutral. As discussed in section 4.3, while Low effectiveness did not represent a Poor effectiveness rating (user satisfaction, service quality), it did represent the lowest ratings of the organizations studied. During the interview process, organizations admitted to having various issues with providing computer support and were looking for ways to improve the delivery of their services. Comparing the participating organizations based on their computer support practices and 
their effectiveness ratings enabled the creation of the revised theoretical model and recommendations to provide additional insight into computer support.

The second limitation concerned the elapsed time between data collection and final results and whether the findings are still relevant. The quantitative and qualitative data was collected in 1997 and the results were not finalized until 2002. Although computer technology changes quite rapidly, organizational structure and other management-related practices change at a lower rate. Support departments always have to react to new technology. The technology will change but the learning curve and other resulting impacts from the adaptation will reoccur. In 1997 several organizations were upgrading their infrastructure from Windows 3.1 to Windows 95 , whereas in 2002, they are upgrading to Windows 2000 or XP. The resulting theoretical model and management recommendations from this study were validated with a few IS managers in 2002 and confirmed to be applicable in the current environment.

The third limitation related to the influence large organizations had on the overall results of the study. As discussed in section 4.4.1.1, all organizations with low computer support effectiveness ratings were large. Although it was confirmed based on this finding that it was harder to provide effective computer support in large organizations, it was not impossible as one large organization did obtain a medium effectiveness rating. Small and medium sized organizations may experience many of the same issues as large organizations with the impacts not being as pronounced. As well, as small and medium 
sized organizations grow, they may experience more computer support-related issues and could learn from the issues larger organizations are facing.

The fourth limitation concerned whether the computer support effectiveness differences between organizations were reflective of the type of support provided or if there were influenced by a general sense of organization climate (i.e., is there a halo/horn effect in companies). Nelson et al. (2000) found that a construct of software operations support expertise was general and context specific environmental factors with one being the business environment. During the interview process, the only organizational changes or influences mentioned that were underway in some of the organizations were technology transitions and organizational restructuring and potential downsizing. As discussed in section 4.8.1.2, there did not appear to be a relationship between organizations undergoing a technology transition or reorganization and effectiveness. During the data collection period, the government departments were undergoing the most organizational reorganization or restructuring yet there were still high, medium, and low computer support effectiveness ratings determined for the various government departments.

The fifth limitation related to the use of a combination of service quality and user satisfaction as the definition of computer support effectiveness. This definition and the corresponding measures provide a user-based view of the services received from the support department. Since not all managers equated computer support success to userrelated criteria (see section 4.5.1.2.4), was the user-based view relevant? From the 
standpoint that none of the organizations participating in this study were in the business of selling computer-related technology, computer support, and IS in general, is not considered core business. From an organizational perspective, the users are the customers in the computer support equation and are in the best position to evaluate if the computer support received met their business needs.

The possibility of questionnaire bias existed. Instruments chosen for the end user survey had been previously tested in an IS setting. The instruments chosen to measure service quality and user satisfaction used perceptual measures (i.e. perceived satisfaction) as opposed to factual measures (\# of calls received per hour). This may have caused problems since people perceive things differently and might not give as precise an answer as a factual measure. Factual measures did not describe the opinions of the users. Since the main focus of computer support is the end user, perceptual measures seemed to be the most appropriate choice.

Another possible limitation is interviewer bias. Many of the questions were openended could be influenced by the interviewer. One interviewer conducted all of the interviews so the interview style remained constant. The questions were open-ended but in a structured order that the interviewer followed. The questions were pre-tested to ensure completeness. The interviews were tape recorded to account for possible memory lapses. The interviewer did not know the results of the end user surveys in advance so could not influence the interviewee based on whether the company rated good or bad from the user point of view. Interviews were felt necessary to fully explore the topic 
area. The interviewer was able to probe for answers on areas that are unclear or not mentioned. Questionnaires would only give data on the subject area but would not be able to answer the question of "Why do they do this or say that?"

Data collection provided both quantitative and qualitative data. The statistical analysis on the qualitative data was limited due to the small number of observations of unique firms (unit of analysis). This was necessary to gain detailed information on each organization.

\subsection{Suggestions for Future Research}

How can organizations provide effective computer support? A model of computer support effectiveness was created in this study to use for future research and as a roadmap for IS managers to highlight areas for improving support. The model is divided into five main independent variable groupings: Organizational Structure, Management Attitudes / Practices, Computer Support Personnel, End User Experience / Needs, and Resources.

The following sections outline areas that should be investigated further to provide more insight into the support function's effectiveness.

\subsubsection{Organizational Structure}

With respect to organizational structure, the relationship of company type and size to computer support effectiveness was supported based on this study's results. There was 
insufficient differentiation with respect to the rank of the executive in charge of IT. This most likely holds true for most organizations so future investigation is not recommended.

The relationship between support department structure and computer support effectiveness was inconclusive. There was enough evidence based on the interviews to propose a new hypothesis concerning the effectiveness benefits of closely aligned support and application groups. Additional investigation is recommended on the support department structure.

The use and effectiveness of the help desk is an important topic with respect to computer support. Is overall support effectiveness weighted heavily in favour of the users' impression of the service received from the first level of contact? For example, what is the users' perception of the effectiveness of the support received from the help desk versus support received by other support personnel? Other help desk related factors to be investigated include: What is the level of knowledge and experience of help desk personnel? How is the help desk being used (e.g., dispatch or troubleshooting)? What percentage of problems was resolved by help desk would be useful along with an analysis of the methods used to distribute problems not resolved by the help desk (e.g., by person, by group, by priority).

This study has stressed the importance of computer support personnel understanding the users' requirements, impacts, and expectations. But a relationship was not found between effectiveness and the use of dedicated support staff (e.g., organizations where computer support personnel are dedicated to a particular user group 
or department). Additional investigation is required into the causes for this lack of a relationship (e.g., does it depend on the individual person assigned to a particular user group?).

\subsubsection{Management Attitudes / Practices}

With respect to management attitudes and practices, the relationship of service orientation, success measurement, management competence, communication between IS and upper management, and communication between IS departments to computer support effectiveness was supported based on this study's results.

No hypotheses were created with respect to formal organizational policies (e.g., staffing, procurement) and computer support effectiveness. An investigation of the type and level of formal and informal processes, procedures, and plans in place for the IS department, not restricted to strategic plans, would be useful to understand the relationship between planning and support effectiveness. Other process-related questions include: How does the frequency of updates to IT strategic plans and its intended audience impact the usefulness of plans? Is computer support effectiveness improved when IT strategy is linked to business strategy? ${ }^{63}$ What impacts do service quality processes and rewards systems have on computer support effectiveness? ${ }^{64}$

\footnotetext{
${ }^{63}$ Watson et al. (1998). See section 2.3.3.

${ }^{64}$ Watson et al. (1998). See section 2.3.3.
} 
Since most organizations have attempted to implement proactive support mechanisms, it was not possible to state whether having proactive support versus not resulted in improved support effectiveness. The relationship between proactive support and support effectiveness may only become apparent when analyzing the different forms of proactive behaviour. Based on the interview responses, new hypotheses were proposed concerning the relationship of technology standards that meet users' needs and expectations, user involvement, user commitment, preventative maintenance, and system monitoring to computer support effectiveness. Further investigation into proactive support behaviour would be useful, including a compilation of a complete list of proactive behaviour types to gauge the level of proactive activity in an organization as well as a detailed look at proactive measures and their associated cost and impacts.

\subsubsection{Computer Support Personnel}

With respect to computer support personnel, the relationship of morale, stress, job satisfaction, and communication between IS managers and support personnel to computer support effectiveness was supported based on this study's results

A new hypothesis has been proposed stating that computer support personnel with good people skills and the ability to translate between technical and business contexts provide more effective support. An important question concerns what people skills are key to providing computer support. For example: (1) ability to put users in receptive frame of mind, (2) ability to communicate effectively, and (3) ability to eliminate user's 
view of the technical geek stereotype. A formal determination of the level of people skills in the participating organizations was not performed. Although most managers looked for people skills when hiring support staff, it was difficult to assess how good the people skills were in their department. A quantitative measure of a support person's people skills (e.g., personnel reviews, user feedback) is required to better gauge the relationship between people skills and support effectiveness.

Further investigation is required into the relationship between computer support effectiveness and support staff advancement, support staff turnover, job commitment, and perceived job security.

\subsubsection{End Users}

With respect to end users, the relationship of computer skill level, peer support, and communication between IS and end users to computer support effectiveness was supported based on this study's results.

A new hypothesis has been proposed that the level of IS involvement in user training relates to computer support effectiveness. Along with investigating this new hypothesis, other recommended topics include a determination of the end users' opinion of the sufficiency and skill level of the end user training provided.

\subsubsection{Resources}

The relationship of equipment resource issues to computer support effectiveness was supported based on this study's results. 
A key topic related to resources and computer support effectiveness warranting further investigation is what types of methods are used by IS managers to compensate for lack of human resources and a lack of time (e.g., prioritization, short-term contracting). This study has proposed new hypotheses concerning the relationship of well-defined problem prioritization processes and combined user/IS funding model with computer support effectiveness.

\subsubsection{Expectations}

Several IS managers and computer support personnel brought up the difficulty in trying to manage both user and upper management's expectations. A significant difference was not found between organizations with respect to service quality expectations. As discussed in section 4.3, additional investigation is required to evaluate the users expectations for computer support. A measure is required to enable comparison of expectations for computer support within organizations.

\subsection{Closing Notes}

There are several strengths to this particular study. A large breadth of subject matter was examined to look for influences on computer support effectiveness. Five broad independent variable categories were used each containing several variables. The study examined both human-related and technical influences and looked at computer support from a services point of view. Qualitative and/or quantitative data was collected 
from managers, support personnel, as well as end users to gain a balanced perspective of opinions from different points of view.

The importance and need for computer support continues to grow as technology evolves at a fast rate and the variety of computer use in organizations increases. If computer support departments are not able to support the user's computer-related requirements effectively, the user's ability to perform their duties is impeded impacting the organization's performance. To try and address issues related to computer support, this paper has discussed several factors influencing computer support effectiveness and has created a model of computer support effectiveness to use as a base for future investigation into these influencing factors. 


\section{REFERENCES}

Arnoudse, D.M. \& L.P. Ouellette (1986). An introduction to the information center concept. Information Strategy: The Executive's Journal, Winter, 9-12.

Baroudi, JJ., \& W.J. Orlikowski (1988). A short-form measure of user information satisfaction: A psychometric evaluation of notes on use. Journal of Management Information Systems, 4(4), 44-59.

Bergeron, F., S. Rivard, \& L. De Serre (1990). Investigating the support role of the information center. MIS Quarterly, September, 247-260.

Bolton, R.N. \& J.H. Drew (1991). A multistage model of customers' assessments of service quality and value. Journal of Consumer Research, 17, 375-384.

Bowen, D.E. \& B. Schneider (1988). Service marketing and management: implications for organizational behavior. Research in Organizational Behavior, 10, 43-80.

Brancheau, J.C. \& C.V. Brown (1993). The management of end-user computing: status and direction. ACM Computing Surveys, 25(4), 437-482.

Brown, T.J., G.A. Churchill Jr., \& J.P. Peter (1993). Improving the measurement of service quality. Journal of Retailing, 69(1), 127-139.

Burke, R.J. (1995). Management practices, employees' satisfaction and perceptions of quality of service. Psychological Reports, 77, 748-750.

Carman, J.M. (1990). Consumer perceptions of service quality: an assessment of the SERVQUAL dimensions. Journal of Retailing, 66(1), 33-55.

Carr, H.H. (1987). Information centers: the IBM model vs. practice. MIS Quarterly, September, 325-338.

Cheney, P.H., R.I. Mann, \& D.L. Amoroso (1986). Organizational factors affecting the success of end-user computing. Journal of Management Information Systems, 3(1), 65 80 .

Compeau, D.R. \& C.A. Higgins (1995). Computer self-efficacy: development of a measure and initial test. MIS Quarterly, June, 189-211. 
Cronin, J.J. \& S.A. Taylor (1992). Measuring service quality: a reexamination and extension. Journal of Marketing, 56, 55-68.

Cronin, J.J. \& S.A. Taylor (1994). SERVPERF versus SERVQUAL: reconciling performance-based and perceptions-minus-expectations measurement of service quality. . Journal of Marketing, 58, 125-131.

Delone, W.H. \& E.R. McLean (1992). Information Systems Success: The Quest for the Dependent Variable. Information Systems Research 3:1, 60-95.

Doll, W.J. \& G. Torkzadeh (1988). The measurement of end-user computing. MIS Quarterly, June, 259-274.

Fisk, R.P., S.W. Brown, \& M.J. Bitner (1993). Tracking the evolution of the services marketing literature. Journal of Retailing, 69(1), 61-103.

Galletta, D.F. \& A.L. Lederer (1989). Some cautions on the measurement of user information satisfaction. Decision Sciences, 20(3), 419-439.

Gotlieb, J.B., D. Grewel, \& S.W. Brown (1994). Consumer satisfaction and perceived quality: complementary or divergent constructs? Journal of Applied Psychology, 79(6), 875-885.

Halloran, J.P. (1993). Achieving world-class end-user computing. Information Systems Management, Fall, 7-12.

Hussain, D.S. and K.M. Hussain (1992). Information Management: Organization, management and control of computer processing. Great Britain: Prentice Hall International Ltd.

Igbaria, M (1990). End-user computing effectiveness: a structural equation model. OMEGA: International Journal of Management Science, 18(6), 637-652.

Igbaria, M. \& J.H. Greenhaus (1992). Determinants of MIS employees' turnover intentions: a structural equation model. Communications of the ACM, 35(2), 35-49.

Igbaria, M., S. Parasuraman, \& M.K. Badawy (1994). Work experiences, job involvement, and quality of work life among information systems personnel. MIS Quarterly, June, 175-201. 
Ives, B., M.H. Olson, \& J.J. Baroudi (1983). The measurement of user information satisfaction. Communications of the ACM, 26(10), 785-793.

Karten, N. (1994). Assessing customer perceptions. Information Systems Management, Spring, 50-55.

Kettinger, W.J. \& C.C. Lee (1994). Perceived service quality and user satisfaction with the information services function. Decision Sciences, 25(5/6), 737-766.

Kettinger, W.J. \& C.C. Lee (1997). Pragmatic Perspectives on the Measurement of Information Systems Service Quality. MIS Quarterly, June, 223-240.

Lederer, A.L. \& A.L. Mendelow (1987). Information resource planning: overcoming difficulties in identifying top management's objectives. MIS Quarterly, September, 389399.

Lee, D.M.S. (1986). Usage pattern and sources of assistance for personal computer users. MIS Quarterly, December, 313-325.

Lee, D.M.S., E.M. Trauth, \& D. Farwell (1995). Critical skills and knowledge requirements of IS professionals: a joint academic/industry investigation. MIS Quarterly, September, 313-340.

Magal, S.R., H.H. Carr, \& H.J. Watson (1988). Critical success factors for information center managers. MIS Quarterly, September, 413-425.

McLean, E.R. \& L.A. Kappelman (1992-1993). The convergence of organizational and end-user computing. Journal of Management Information Systems, 9(3), 145-155.

Mefford, R.N. (1993). Improving service quality: learning from manufacturing. International Journal of Production Economics, 30-31, 399-413.

Melone, N.P. (1990). A theoretical assessment of the user-satisfaction construct in information systems research. Management Science, 36(1), 76-91.

Mirani, R. \& W.R. King. (1994). Impacts of end-user and information center characteristics on end-user computing support. Journal of Management Information Systems, 11(1), 141-166.

Mittal, B., \& W.M. Lassar (1996). The Role of Personalization in Service Encounters. Journal of Retailing, 72(1), 95-109. 
Munro, M.C., S.L. Huff, B. L. Marcolin, D.R. Compeau (1995). Understanding and measuring end user sophistication. Unpublished.

Murray, R.P. (1996). Making customer service a priority. Information Systems Management, Winter, 7-11.

Nelson, R.R. (1991). Educational needs as perceived by IS and end-user personnel: a survey of knowledge and skill requirement. MIS Quarterly, December, 503-525.

Nelson, K.M. \& J.G. Cooprider (1996). The Contribution of Shared Knowledge to IS Group Performance. MIS Quarterly, December, 409-432.

Nelson, K.M., S. Nadkarni, V.K. Narayanan, M. Ghods (2000). Understanding Software Operations Support Expertise: A Revealed Causal Mapping Approach. MIS Quarterly, September, 475-507.

Parasuraman, A., L.L. Berry, and V.A. Zeithaml (1991). Refinement and reassessment of the SERVQUAL scale. Journal of Retailing, 67(4), 420-450.

Parasuraman, A., L.L. Berry, and V.A. Zeithaml (1993). More on improving the measurement of service quality. Journal of Retailing, Spring, 140-147.

Parasuraman, A., V.A. Zeithaml, and L.L. Berry (1985). A conceptual model of service quality and its implications for future research. Journal of Marketing, 49, 41-50.

Parasuraman, A., V.A. Zeithaml, and L.L. Berry (1988). SERVQUAL: A multiple-item scale for measuring consumer perceptions of service quality. Journal of Retailing. 67(4), $12-40$.

Parasuraman, A., V.A. Zeithaml, and L.L. Berry (1994a). Reassessment of expectations as a comparison standard in measuring service quality: implications for further research. Journal of Marketing, 58, 111-124.

Parasuraman, A., V.A. Zeithaml, and L.L. Berry (1994b). Alternative scales for measuring service quality: a comparative assessment based on psychometric and diagnostic criteria. Journal of Retailing, 70(3), 291-230.

Patching, K. (1989). The Information Centre: Managing the Growth of End-User Computing to Corporate Advantage. London: Quiler Press Limited. 
Pitt, L.F., R.T. Watson, \& C.B. Kavan (1995). Service quality: a measure of information systems effectiveness. MIS Quarterly, June, 173-187.

Pitt, L.F., R.T. Watson, \& C.B. Kavan (1997). Measuring Information Systems Service Quality: Concerns for a Complete Canvas. MIS Quarterly, June, 209-221.

Reeves, C.A. \& D.A. Bednar (1994). Defining quality: alternatives and implications. Academy of Management Review, 19(3), 419-445.

St. Clair, Guy (1993). Customer Service in the Information Environment. London: Bowker-Saur.

Teas, R.K. (1993). Expectations, performance evaluation, and consumers' perceptions of quality. Journal of Marketing, 57, 18-34.

Teas, R.K. (1994). Expectations as a comparison standard in measuring service quality: an assessment of a reassessment. Journal of Marketing, 58, 132-139.

Van Dyke, T.P., L.A. Kappelman, V.R. Prybutok (1997). Measuring Information Systems Service Quality: Concerns on the Use of the SERVQUAL Questionnaire. MIS Quarterly, June, 195-208.

Watson, R.T., L.F. Pitt, \& C.B. Kavan (1998). Measuring Information Systems Service Quality: Lessons from Two Longitudinal Case Studies. MIS Quarterly, March, 61-70.

White, C.E., Jr. \& D.P. Christy (1987). The information system concept: a normative model and a study of six installations. MIS Quarterly, December, 451-458.

Yin, Robert K. (1989). Case Study Research: Design and Methods. United States: Sage Publications.

Yoshida, Kosaku (1993). The joy of work: optimizing service quality through education and training. Quality Progress, November, 29-33.

Zeithaml, V.A., A. Parasuraman, and L.L. Berry (1985). Problems and strategies in services marketing. Journal of Marketing, 49, 33-46. 


\section{APPENDICES}

Appendix 1: Management Interview Questions

\section{Support Department Structure}

1. How many departments in your organization provide computer support?

2. Is the support function centralized or decentralized?

3. Who does the support function report to?

4. What type of applications/systems does your department support? Other departments?

5. Approximately how many support personnel are employed in your department? Other departments?

6. What levels are the various personnel (i.e. technical, supervisory, managerial) who do support?

\section{Support Staff Personnel}

7. Who hires the support personnel in your organization?

- IS managers/staff, human resources management/staff, a combination of the two

8. What do you look for when hiring support personnel?

- education

- technical skills

- related work experience

- people skills 
9. What is the average age of the support personnel? (younger, older, mixture)

10. Do support personnel advance within the support function or do they move on to other areas within IS?

11. Is there a large support staff turnover in your department?

- Are people leaving for other positions within the company or are they leaving the company?

- Why do they leave? (stress, money, advancement)

12. How much training do support staff receive?

\section{End-Users}

13. How many end-users are supported by your department? Other support departments?

14. What type of users do you support in terms of computer skills? (novice, intermediate, expert)

15. Who do the users contact when they have a problem? (centralized help desk, support personnel directly)

16. Why do the users require support? (lack of training, problems with existing systems, new installations)

17. Who does user training? (support function or other departments)

18. Do you feel that more training provided to end-users would decrease the amount of support they require?

19. Is support done in a proactive manner as well as reactive? 


\section{Problems Faced by Support Function}

20. How do you define success? How do you know you are doing well?

21. What are the biggest problems facing the support function?

- resources, time, demands/expertise of end-users, training, support personnel

22. How are you trying to solve these problems?

23. What problems have you faced in the past? How did you solve them?

24. How do you monitor problems?

25. How important are the support departments relative to development departments in terms of allocation of resources?

26. How do you think the IS department will change in the next ten years (importance of support, structure)

27. Is any outsourcing done in IS in the organization?

28. Is there a strategic plan for the IS department? Are there any organizational policies or procedures that help/hinder your work?

29. How is the communication between:

. top management and IS?

- IS management and support personnel?

. IS departments?

. IS and end users? 


\section{Appendix 2: Support Personnel Interview Questions}

1. What are the biggest problems that you encounter while doing support? Prompt for examples from each of the following:

- lack of resources

- lack of time

- end-users (don't know enough, know too much)

- lack of management support

- lack of training

- stress

2. What is your educational background? Is your education primarily technical?

3. How important are people skills to the work you do?

4. Have you had any formal training in interpersonal skills?

5. Do you plan on doing support as a career or is this a stepping stone to move on to something different? How is turnover and morale in your department?

6. How much overtime do you work?

7. How satisfied are you with your job?

8. To what extent do you feel you are representing the support function as a whole?

9. What is your opinion of the different types of end-users that you encounter?

10. Do you feel that there is an emphasis on fixing problems quickly as opposed to 
spending more time doing a more complete job? Is there anything your manager could do to alleviate this situation?

11. Do you spend any time teaching users new skills/information so that they will need less support in the future?

12. How is communication between:

- IS management and IS personnel?

- IS departments?

- IS and end users?

13. How many years have you been:

- doing support?

- doing other IS-related jobs?

- doing other non-IS related jobs? 
Appendix 3: End User Questionnaire

\section{Instructions}

As part of a study on the effectiveness of computer support, we are trying to understand how users feel about the computer support that is provided in their organization. Your input into this study is important. We need to know your opinion on different aspects of computing in your organization.

Throughout the questionnaire there will be references to the Information Systems department. This specifically deals with departments in your organization that provide you with computer support. In your organization this would represent:

This questionnaire contains four sections. The first section asks questions pertaining to your expectations and perceptions of the computer support department's performance. The second section measures your satisfaction with the Information Systems function. The third section asks questions on how familiar you are with information technology. The final section asks for some background information about yourself. This information will be used to identify whether different groups of people have different opinions on the effectiveness of computer support. 
None of the information will be used to identify who you are. The questionnaire is anonymous. Please try to answer all of the questions. Remember, there are no right or wrong answers. We are interested in your opinion.

When you have completed the questionnaire, please put it in the self-addressed, stamped envelope provided and put it in the mail.

If you have any questions about the questionnaire, or would like to discuss the research further, please do no hesitate to call me at (613) 749-6424.

Thank you for participating.

\author{
Marlene Elliott \\ Project Coordinator, Computer Support Study \\ School of Business, Carleton University \\ Ottawa, Ontario \\ K1S 5L5
}




\section{Part 1: Service Quality Measurement}

\section{Service Quality Expectations}

Directions: This survey deals with your opinion of the Information Systems (IS) Department. Based on your experiences as a user, please think about the kind of IS unit that would deliver excellent quality of service. Think about the kind of IS unit with which you would be pleased to do business. Please show the extent to which you think such a unit would possess the feature described by each statement. If you strongly agree that these units should possess a feature, circle 7. If you strongly disagree that these units should possess a feature, circle 1. If your feeling is less strong, circle one of the numbers ain the middle. There are no right or wrong answers - all we are interested in is a number that truly reflects your expectations about IS.

Please respond to ALL the statements.

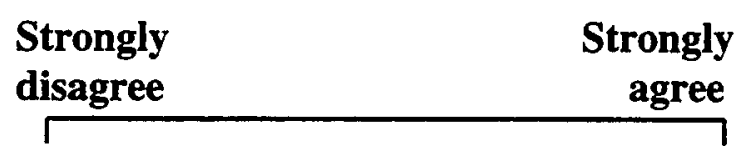

$\begin{array}{lllllllllll}\text { 1. IS will have up-to-date hardware and } & & 1 & 2 & 3 & 4 & 5 & 6 & 7\end{array}$ software.

2. When these IS units promise to do something, they will do so.

$\begin{array}{lllllll}1 & 2 & 3 & 4 & 5 & 6 & 7\end{array}$

3. Employees will always be willing to help $\quad \begin{array}{llllllllll}1 & 2 & 3 & 4 & 5 & 6 & 7\end{array}$ users. 
4. Employees will have the knowledge to do $\quad \begin{array}{llllllllll} & 1 & 2 & 3 & 4 & 5 & 6 & 7\end{array}$ their job well.

$\begin{array}{lllllllllll}\text { 5. These IS units will have employees who } & & 1 & 2 & 3 & 4 & 5 & 6 & 7\end{array}$ give users personal attention.

6. IS's physical facilities will be visually appealing.

7. These IS units will have the user's best interests at heart.

$\begin{array}{llllllllllll}\text { 8. They will provide their services at the } & & 1 & 2 & 3 & 4 & 5 & 6 & 7\end{array}$ times they promise to do so.

$\begin{array}{lllllllllll}\text { 9. The behaviour of employees will instill } & 1 & 2 & 3 & 4 & 5 & 6 & 7\end{array}$ confidence in users.

$\begin{array}{llllllllll}\text { 10. They will tell users exactly when services } & 1 & 2 & 3 & 4 & 5 & 6 & 7\end{array}$ will be performed.

11. These IS units will have operating hours $\quad \begin{array}{llllllllll}1 & 2 & 3 & 4 & 5 & 6 & 7\end{array}$ convenient to all their users.

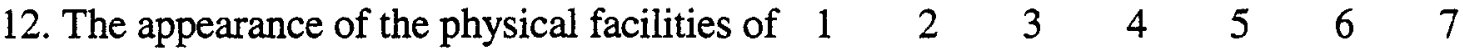
these IS units will be in keeping with the kind of services provided.

13. These IS units will give users individual $\quad \begin{array}{lllllllll}1 & 2 & 3 & 4 & 5 & 6 & 7\end{array}$ attention.

14. Employees will be consistently courteous $\quad \begin{array}{llllllllll} & 1 & 2 & 3 & 4 & 5 & 6 & 7\end{array}$ with users.

15. These IS units will be dependable.

$\begin{array}{lllllll}1 & 2 & 3 & 4 & 5 & 6 & 7\end{array}$


16. Employees will never be too busy to respond to users' requests.

$\begin{array}{lllllll}1 & 2 & 3 & 4 & 5 & 6 & 7\end{array}$

17. When users have a problem, these IS units $\begin{array}{lllllllll}1 & 2 & 3 & 4 & 5 & 6 & 7\end{array}$ show a sincere interest in solving it.

18. Their employees will be well dressed and $\begin{array}{lllllllll}1 & 2 & 3 & 4 & 5 & 6 & 7\end{array}$ neat in appearance.

19. Employees will give prompt service to $\quad \begin{array}{lllllllll}1 & 2 & 3 & 4 & 5 & 6 & 7\end{array}$ users.

20. The employees of these IS units understand $\begin{array}{lllllllll}1 & 2 & 3 & 4 & 5 & 6 & 7\end{array}$ the specific needs of their users.

21. They will maintain fully-functional equipment and software.

22. They will perform their services right the $\begin{array}{lllllllll}1 & 2 & 3 & 4 & 5 & 6 & 7\end{array}$ first time.

23. Users will feel safe in their transactions $\quad \begin{array}{llllllll}1 & 2 & 3 & 4 & 5 & 6 & 7\end{array}$ with these IS units' employees. 


\section{Service Quality Perceptions}

Directions: The following set of statements relate to your feelings about your organization's Information Systems (IS) unit. For each statement, please show the extent to which you believe your organization's IS unit has the feature described by the statement. Once again, circling a 7 means that you strongly agree that your organization's IS unit has that feature, and circling a 1 means that you strongly disagree. You may circle any of the numbers in the middle that show how strong your feelings are. There are no right or wrong answers - all we are interested in is a number that best shows your perceptions about your organization's IS unit.

Please respond to ALL the statements.

\section{Strongly disagree}

Strongly

agree

1. IS has up-to-date hardware and software.

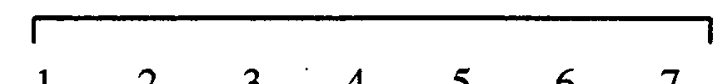

2. When IS promises to do something, it does so.

3. IS employees are always willing to help users.

4. IS employees have the knowledge to do $\quad \begin{array}{lllllllllll} & 1 & 2 & 3 & 4 & 5 & 6 & 7\end{array}$ their job well.

$\begin{array}{lllllllllll}\text { 5. IS has employees who give users personal } & 1 & 2 & 3 & 4 & 5 & 6 & 7\end{array}$ attention. 
6. IS's physical facilities are visually

$\begin{array}{lllllll}1 & 2 & 3 & 4 & 5 & 6 & 7\end{array}$ appealing.

7. IS has the users' best interests at heart. $\quad \begin{array}{llllllll}1 & 2 & 3 & 4 & 5 & 6 & 7\end{array}$

8. IS provides its services at the times it $\quad \begin{array}{lllllllll}1 & 2 & 3 & 4 & 5 & 6 & 7\end{array}$ promises to do so.

9. The behaviour of IS employees instills $\quad \begin{array}{llllllllll}1 & 2 & 3 & 4 & 5 & 6 & 7\end{array}$ confidence in users.

10. IS tells users exactly when services will be $\begin{array}{lllllllll}1 & 2 & 3 & 4 & 5 & 6 & 7\end{array}$ performed.

11. IS has operating hours convenient to all its $\begin{array}{lllllllll}1 & 2 & 3 & 4 & 5 & 6 & 7\end{array}$ users.

12. The appearance of the physical facilities of $\begin{array}{lllllllll}1 & 2 & 3 & 4 & 5 & 6 & 7\end{array}$ IS is in keeping with the kind of services provided.

$\begin{array}{llllllllll}\text { 13. IS gives users individual attention. } & & 1 & 2 & 3 & 4 & 5 & 6 & 7\end{array}$

14. IS employees are consistently courteous $\quad \begin{array}{lllllllll}1 & 2 & 3 & 4 & 5 & 6 & 7\end{array}$ with users.

$\begin{array}{llllllll}\text { 15. IS is dependable. } & 1 & 2 & 3 & 4 & 5 & 6 & 7\end{array}$

16. IS employees are never too busy to $\quad \begin{array}{llllllllll}1 & 2 & 3 & 4 & 5 & 6 & 7\end{array}$ respond to users' requests.

$\begin{array}{lllllllll}\text { 17. When users have a problem, IS shows a } & 1 & 2 & 3 & 4 & 5 & 6 & 7\end{array}$ sincere interest in solving it.

18. IS's employees are well dressed and neat $\begin{array}{lllllllll}1 & 2 & 3 & 4 & 5 & 6 & 7\end{array}$ in appearance. 


\section{Strongly}

disagree

\section{$r$}

19. IS employees give prompt service to users. $\begin{array}{lllllllll}1 & 2 & 3 & 4 & 5 & 6 & 7\end{array}$

20. Employees of IS understand the specific $\quad \begin{array}{llllllll}1 & 2 & 3 & 4 & 5 & 6 & 7\end{array}$ needs of its users.

21. IS maintains fully-functional equipment $\quad \begin{array}{llllllll}1 & 2 & 3 & 4 & 5 & 6 & 7\end{array}$ and software.

22. IS performs its services right the first time. $\begin{array}{lllllllll}1 & 2 & 3 & 4 & 5 & 6 & 7\end{array}$

23. Users will feel safe in their transactions $\quad \begin{array}{llllllll}1 & 2 & 3 & 4 & 5 & 6 & 7\end{array}$ with IS's employees.

Now, please complete the following:

1. Overall, how would you rate the quality of service provided by IS? Please indicate your assessment by circling one of the numbers on the scale below:

$\begin{array}{lllllll}\text { Poor } & & & & & & \text { Excellent } \\ 1 & 2 & 3 & 4 & 5 & 6 & 7\end{array}$




\section{Part 2: Satisfaction Summary}

Please circle the number that best represents your level of satisfaction concerning the following areas.

1. How satisfied are you with your involvement and participation in the operation and ongoing development of information systems?

\begin{tabular}{llllllll}
$\begin{array}{l}\text { Not } \\
\text { Satisfied }\end{array}$ & & & Satisfied \\
\hline 1 & 2 & 3 & 4 & 5 & 6 & 7
\end{tabular}

2. How satisfied are you with the support and services of the Information Systems (IS) department?

\begin{tabular}{llllllll}
$\begin{array}{l}\text { Not } \\
\text { Satisfied }\end{array}$ & & & & Satisfied \\
\hline 1 & 2 & 3 & 4 & 5 & 6 & 7
\end{tabular}

3. How satisfied are you with the information/data produced by the information systems?

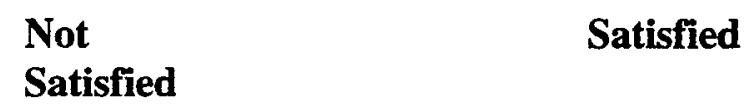

\begin{tabular}{lllllll}
\hline 1 & 2 & 3 & 4 & 5 & 6 & 7
\end{tabular}

4. In summary, how satisfied are you with the entire information systems environment?

\begin{tabular}{lllllll}
$\begin{array}{l}\text { Not } \\
\text { Satisfied }\end{array}$ & & & Satisfied \\
\hline 1 & 2 & 3 & 4 & 5 & 6 & 7
\end{tabular}




\section{Part 3: Information Technology Familiarity}

We need to know how many software packages you are able to use and how many technology concepts you understand.

Your first impressions are the ones of most interest to us, so do not spend an excessive amount of time on any one question. In some cases you may have forgotten some of what you once knew about an item. Please respond based on your current knowledge of that item.

A few questions ask you to assess your general impression of complex issues. If you find it difficult to determine your exact answer, please give your best estimate.

You may skip many items in this part of the questionnaire, if you have never studied or used the technology. 


\section{Section A}

This section asks about your knowledge of software applications. You will be asked to estimate how much you know about a wide range of software.

\begin{tabular}{|c|c|c|c|c|c|c|c|c|c|c|c|}
\hline Have you used... & \multicolumn{2}{|c|}{ Circle number } & & $\begin{array}{l}\text { How Many } \\
\text { Do You } \\
\text { Have a } \\
\text { Working } \\
\text { Knowledge } \\
\text { of? } \\
\quad \downarrow\end{array}$ & $\begin{array}{r}\text { Ho } \\
\mathrm{Cu} \\
\frac{8}{2} \\
\frac{8}{2}\end{array}$ & 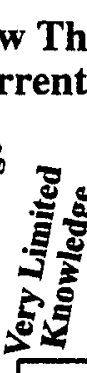 & $\begin{array}{l}\text { hor } \\
\text { t } K\end{array}$ & $\begin{array}{l}\text { oug } \\
\text { nox }\end{array}$ & $\begin{array}{l}\text { h is } \\
\text { vled }\end{array}$ & ن & 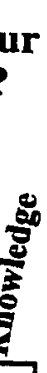 \\
\hline $\begin{array}{l}\text { SPREADSHEETS } \\
\text { (e.g., Lotus, Quattro Pro, Excel) }\end{array}$ & $\begin{array}{c}\text { No } \\
1\end{array}$ & $\begin{array}{c}\text { Yes } \\
2\end{array}$ & $\begin{array}{l}\text { if yes, } \\
\text { please }> \\
\text { answer }\end{array}$ & & 0 & 12 & 23 & 4 & 5 & 6 & 7 \\
\hline $\begin{array}{l}\text { DATABASES } \\
\text { (e.g., dBase, RBase, Oracle })\end{array}$ & $\begin{array}{c}\text { No } \\
1\end{array}$ & $\begin{array}{c}\text { Yes } \\
2\end{array}$ & $\begin{array}{l}\text { if yes, } \\
\text { please } \\
\text { answer }\end{array}$ & & 0 & 12 & 3 & 4 & 5 & 6 & 7 \\
\hline $\begin{array}{l}\text { WORD PROCESSING } \\
\text { (e.g., Word Perfect, MS Word) }\end{array}$ & $\begin{array}{c}\text { No } \\
1\end{array}$ & $\begin{array}{c}\text { Yes } \\
2\end{array}$ & $\begin{array}{l}\text { if yes, } \\
\text { please } \\
\text { answer }\end{array}$ & & 0 & 12 & 23 & 4 & 5 & 6 & 7 \\
\hline $\begin{array}{l}\text { GRAPHICS } \\
\text { (e.g., those to create graphs and } \\
\text { charts, and those for drawing free- } \\
\text { form figures) }\end{array}$ & $\begin{array}{c}\text { No } \\
1\end{array}$ & $\begin{array}{c}\text { Yes } \\
2\end{array}$ & $\begin{array}{l}\text { if yes, } \\
\text { please } \\
\text { answer }\end{array}$ & & 0 & 12 & 3 & 4 & 5 & 6 & 7 \\
\hline $\begin{array}{l}\text { DESKTOP PUBLISHING } \\
\text { (e.g., Pagemaker, Ventura) }\end{array}$ & $\begin{array}{c}\text { No } \\
1\end{array}$ & $\begin{array}{c}\text { Yes } \\
2\end{array}$ & $\begin{array}{l}\text { if yes, } \\
\text { please } \\
\text { answer }\end{array}$ & & 0 & 12 & 3 & 4 & 5 & 6 & 7 \\
\hline ELECTRONIC MAIL & $\begin{array}{c}\text { No } \\
1\end{array}$ & $\begin{array}{c}\text { Yes } \\
2\end{array}$ & $\begin{array}{l}\text { if yes, } \\
\text { please } \\
\text { answer }\end{array}$ & & 0 & 12 & 3 & 4 & 5 & 6 & 7 \\
\hline $\begin{array}{l}\text { TELECOMMUNICATION } \\
\text { PACKAGES } \\
\text { (e.g., Kermit, Procomm, Crosstalk) }\end{array}$ & $\begin{array}{c}\text { No } \\
1\end{array}$ & $\begin{array}{c}\text { Yes } \\
2\end{array}$ & $\begin{array}{l}\text { if yes, } \\
\text { please } \\
\text { answer }\end{array}$ & & 0 & 12 & 3 & 4 & 5 & 6 & 7 \\
\hline $\begin{array}{l}\text { PERSONAL } \\
\text { INFORMATION } \\
\text { MANAGERS } \\
\text { (e.g., Packages that do scheduling, } \\
\text { calendaring, and "to do" lists) }\end{array}$ & $\begin{array}{c}\text { No } \\
1\end{array}$ & $\begin{array}{c}\text { Yes } \\
2\end{array}$ & $\begin{array}{l}\text { if yes, } \\
\text { please } \\
\text { answer }\end{array}$ & & 0 & 12 & 3 & 4 & 5 & 6 & 7 \\
\hline
\end{tabular}




\begin{tabular}{|c|c|c|c|c|c|c|c|c|c|c|c|c|}
\hline \multirow{2}{*}{$\begin{array}{l}\text { Have you used... } \\
\text { STATISTICS }\end{array}$} & \multicolumn{2}{|c|}{ Circle number } & & $\begin{array}{l}\text { How Many } \\
\text { Do You } \\
\text { Have a } \\
\text { Working } \\
\text { Knowledge } \\
\text { of? } \\
\quad \downarrow\end{array}$ & \multicolumn{8}{|c|}{$\begin{array}{l}\text { How Thorough is your } \\
\text { Current Knowledge? }\end{array}$} \\
\hline & $\begin{array}{c}\text { No } \\
1\end{array}$ & $\begin{array}{c}\text { Yes } \\
2\end{array}$ & $\begin{array}{l}\text { if yes, } \\
\text { please } \\
\text { answer }\end{array}$ & & 0 & 1 & 2 & 3 & 4 & 5 & 6 & 7 \\
\hline $\begin{array}{l}\text { REPORT GENERATORS/ } \\
\text { QUERY LANGUAGES } \\
(e . g ., S Q L, A D R S I I, \\
Q B E)\end{array}$ & $\begin{array}{c}\text { No } \\
1\end{array}$ & $\begin{array}{c}\text { Yes } \\
2\end{array}$ & $\begin{array}{l}\text { if yes, } \\
\text { please } \\
\text { answer }\end{array}$ & & 0 & 1 & 2 & 3 & 4 & 5 & 6 & 7 \\
\hline $\begin{array}{l}\text { PERSONAL COMPUTER } \\
\text { OPERATING SYSTEMS } \\
\text { (e.g., DOS, OS } / 2 \text {, Windows, } \\
\text { PC-Unix, MacIntosh) }\end{array}$ & $\begin{array}{c}\text { No } \\
1\end{array}$ & $\begin{array}{c}\text { Yes } \\
2\end{array}$ & $\begin{array}{l}\text { if yes, } \\
\text { please } \\
\text { answer }\end{array}$ & & 0 & 1 & 2 & 3 & 4 & 5 & 6 & 7 \\
\hline $\begin{array}{l}\text { MAINFRAME OR } \\
\text { MINICOMPUTER } \\
\text { OPERATING SYSTEMS } \\
\text { (e.g., MVS, VM, Unix) }\end{array}$ & $\begin{array}{c}\text { No } \\
1\end{array}$ & $\begin{array}{c}\text { Yes } \\
2\end{array}$ & $\begin{array}{l}\text { if yes, } \\
\text { please } \\
\text { answer }\end{array}$ & & 0 & 1 & 2 & 3 & 4 & 5 & 6 & 7 \\
\hline $\begin{array}{l}\text { PROCEDURAL } \\
\text { ("third generation") } \\
\text { PROGRAMMING } \\
\text { LANGUAGES } \\
\text { (e.g., Basic, Pascal, C, } \\
\text { PLi, Fortran, Cobol, APL, } \\
\text { Assembly Language) }\end{array}$ & $\begin{array}{c}\text { No } \\
1\end{array}$ & $\begin{array}{c}\text { Yes } \\
2\end{array}$ & $\begin{array}{l}\text { if yes, } \\
\text { please } \\
\text { answer }\end{array}$ & & 0 & 1 & 2 & 3 & 4 & 5 & 6 & 7 \\
\hline $\begin{array}{l}\text { NONPROCEDURAL } \\
\text { ("fourth generation") } \\
\text { PROGRAMMING } \\
\text { LANGUAGES } \\
\text { (e.g., Focus, Mapper, Ramis, Nomad) }\end{array}$ & $\begin{array}{c}\text { No } \\
1\end{array}$ & $\begin{array}{c}\text { Yes } \\
2\end{array}$ & $\begin{array}{l}\text { if yes, } \\
\text { please } \\
\text { answer }\end{array}$ & & 0 & 1 & 2 & 3 & 4 & 5 & 6 & 7 \\
\hline $\begin{array}{l}\text { COMPANY SPECIFIC } \\
\text { PACKAGES } \\
\text { (e.g., accounts receivable, } \\
\text { accounts payable, inventory, etc) }\end{array}$ & $\begin{array}{c}\text { No } \\
1\end{array}$ & $\begin{array}{c}\text { Yes } \\
2\end{array}$ & $\begin{array}{l}\text { if yes, } \\
\text { please } \\
\text { answer }\end{array}$ & & 0 & 1 & 2 & 3 & 4 & 5 & 6 & 7 \\
\hline $\begin{array}{l}\text { DATABASE DESIGN } \\
\text { (e.g., normalization, entity- } \\
\text { relationship diagrams, cardinality) }\end{array}$ & $\begin{array}{c}\text { No } \\
1\end{array}$ & $\begin{array}{c}\text { Yes } \\
2\end{array}$ & $\begin{array}{l}\text { if yes, } \\
\text { please } \\
\text { answer }\end{array}$ & & 0 & 1 & 2 & 3 & 4 & 5 & 6 & 7 \\
\hline
\end{tabular}


Have you used...

SYSTEM ANALYSIS AND DESIGN

(e.g., needs assessment, feasibility studies, data modelling, logical and physical data models, program design)

PERSONAL COMPUTING HARDWARE

(e.g., IBM, Apple, MacIntosh,

Sun Workstations, Compatibles)

MAINFRAME, MINICOMPUTER, OR SUPERCOMPUTER

HARDWARE

(e.g., IBM, DEC, CRAY,

$C D C$ Cyber)

\section{LOCAL AREA}

NETWORKS

(e.g., using shared disks on other computers in the network setting up and controlling

remote printing, exchanging files)

\section{PUBLIC PACKET-}

SWITCHED NETWORKS

(e.g., Knowing how to connect a personal computer through a packet-switched network such as Datapac or Telnet to

access another remote computer)

Have you...

ACCESSED EXTERNAL DATA

(e.g. How to access data stored on another computer, including transferring to your local computer)
Circle number

$\begin{array}{cc}\text { No } & \text { Yes } \\ 1 & 2\end{array}$

if yes,

\section{please}

answer

How Many

Do You

Have a

Working

Knowledge of?

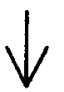

How Thorough is your Current Knowledge?

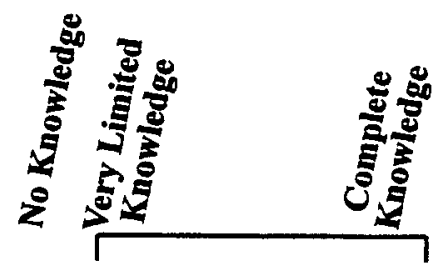

$\begin{array}{llllllll}0 & 1 & 2 & 3 & 4 & 5 & 6 & 7\end{array}$

$\begin{array}{cc}\text { No } & \text { Yes } \\ 1 & 2\end{array}$

if yes,

please

answer

$\begin{array}{llllllll}0 & 1 & 2 & 3 & 4 & 5 & 6 & 7\end{array}$

No Yes

if yes,

please

12

answer

$\begin{array}{llllllll}0 & 1 & 2 & 3 & 4 & 5 & 6 & 7\end{array}$

No Yes

if yes,

please

12

answer

$\begin{array}{llllllll}0 & 1 & 2 & 3 & 4 & 5 & 6 & 7\end{array}$

No Yes if yes,

$1 \quad 2 \quad \begin{aligned} & \text { please } \\ & \text { answer }\end{aligned}$

$\begin{array}{llllllll}0 & 1 & 2 & 3 & 4 & 5 & 6 & 7\end{array}$

$\begin{array}{cc}\text { No } & \text { Yes } \\ 1 & 2\end{array}$

if yes,

please

answer 
Have you used...

Circle number

Have you...

LEARNED

TELECOMMUNICATIONS

PRINCIPLES

(e.g., What a modem is for,

transmission speeds (i.e., "baud rates"), pros and cons of

telecommunications media such as

twisted pair, coaxial cable, or

fibre optics)

Have you used...

A MODEM
How Many How Thorough is your

Do You

Current Knowledge?

Have a

Working

Knowledge

of?
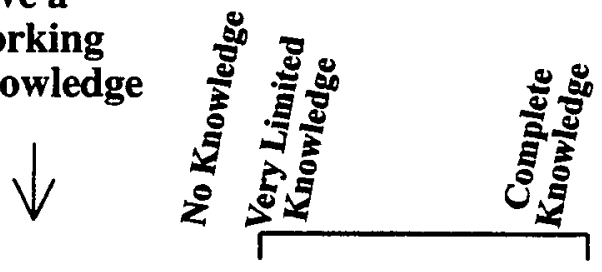

$\begin{array}{llllllll}0 & 1 & 2 & 3 & 4 & 5 & 6 & 7\end{array}$
No Yes please

answer

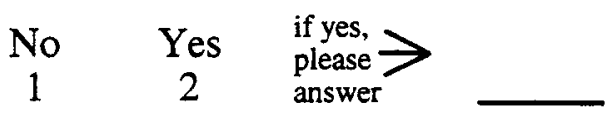

$\begin{array}{llllllll}0 & 1 & 2 & 3 & 4 & 5 & 6 & 7\end{array}$ 


\section{Section B}

This section asks about computer usage and general Information Technology knowledge. (Please circle the appropriate number)

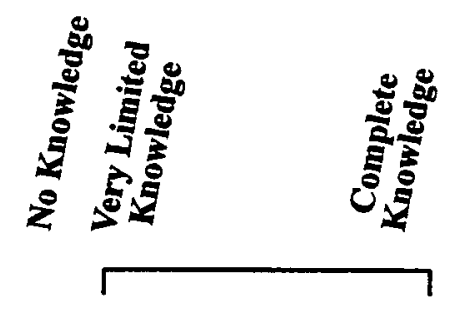

B-1. How thorough is your current knowledge of "computer hygiene" (e.g., How to make a computer system secure, to perform proper backups, and to recover from a malfunction)?

B-2. How thorough is your current knowledge of computer hardware concepts (e.g., How a computer works including such things as the role of the processor, the main memory, secondary storage, input and output devices)?

B-3. How thorough is your current knowledge of software principles (e.g., structured programming, the advantages and disadvantages of various programming languages)?

B-4. How thorough is your current knowledge of system performance (e.g., How the various components impact the system's speed and throughput)?

B-5. How thorough is your current knowledge of software testing (e.g., How to test a computer program or system so as to insure that it functions correctly)? 
B-6. On the average, how frequently do you use a computer system at work? (Circle number)
1 LESS THAN ONCE A MONTH
2 ONCE A MONTH
3 A FEW TIMES A MONTH
4 A FEW TIMES A WEEK
5 ABOUT ONCE A DAY
6 SEVERAL TIMES A DAY

B-7. On the average working day that you use a computer, how much time do you spend on the machine?

B-8. How thorough is your current knowledge of information system policies and plans within your organization? (Circle Number)
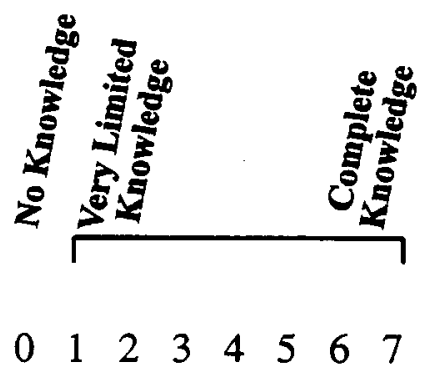

B-9. How thorough is your current knowledge of the potential for using information systems/technology within your department?

\begin{tabular}{llllllll} 
Never & \multicolumn{1}{c}{} & \multicolumn{4}{c}{ Frequently } \\
1 & 2 & 3 & 4 & 5 & 6 & 7
\end{tabular}

$\begin{array}{lc}\text { Extremely } & \text { Extremely } \\ \text { Poor } & \text { Good }\end{array}$

B-11. In general, how capable are you at applying computers to solve problems at work?

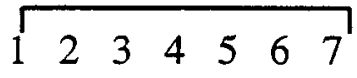

$\begin{array}{rr}\text { Extremely } & \text { Extremely } \\ \text { Uncreative } & \text { Creative }\end{array}$

B-12. In general, how creative would you say you are in using software packages to solve business problems?

1223045667 


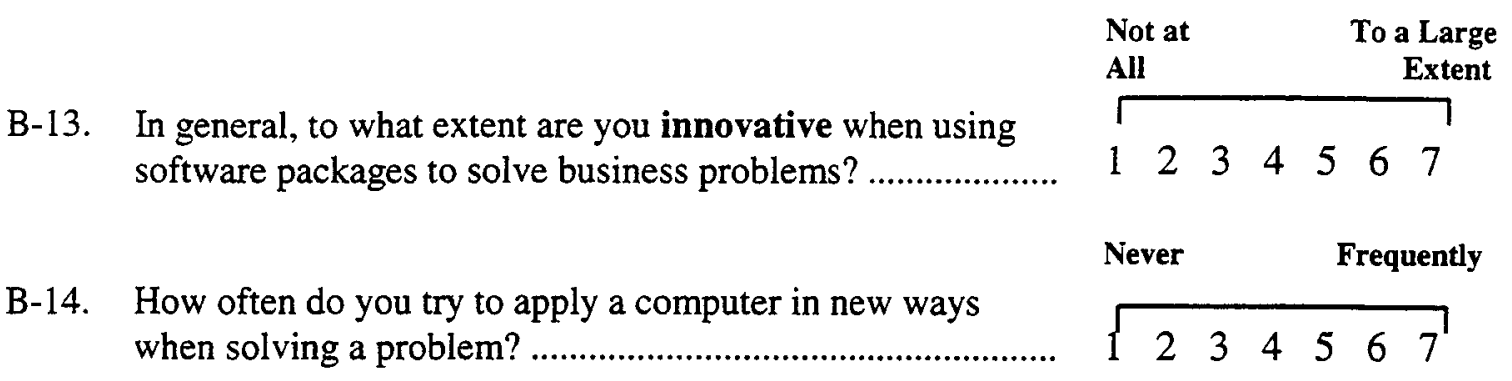

B-15. Please list all the different ways you have used word processing. (e.g., creating letters or memos would be considered the same thing).

B-16. On average, how frequently do you contact a member of the computer support staff for help with computer-related problems (hardware or software)? (Circle number)

\section{LESS THAN ONCE A MONTH \\ 2 ONCE A MONTH \\ 3 A FEW TIMES A MONTH \\ 4 A FEW TIMES A WEEK \\ 5 ABOUT ONCE A DAY \\ 6 SEVERAL TIMES A DAY}

Overall, how satisfied were you with the help you received from the computer support staff?

\begin{tabular}{lllllll}
$\begin{array}{l}\text { Not } \\
\text { Satisfied }\end{array}$ & & & & \multicolumn{3}{c}{ Satisfied } \\
\hline 1 & 2 & 3 & 4 & 5 & 6 & 7
\end{tabular}

B-17. On average, how frequently do you ask co-workers for help with computer-related problems (hardware or software)? (Circle number) 
1 LESS THAN ONCE A MONTH

2 ONCE A MONTH

3 A FEW TIMES A MONTH

4 A FEW TIMES A WEEK

5 ABOUT ONCE A DAY

6 SEVERAL TIMES A DAY

Overall, how satisfied were you with the help you receive from your co-workers?

Not

Satisfied

Satisfied

\begin{tabular}{|lllllll}
\hline 1 & 2 & 3 & 4 & 5 & 6 & 7
\end{tabular}

\section{Part 4: General Questions}

1. How long have your worked in your present organization?

YEARS and MONTHS

2. What is your functional area? (circle number)

1. ACCOUNTING

2. ENGINEERING, DESIGN, R\&D

3. FINANCE

4. GENERAL MANAGEMENT

5. MANUFACTURING / PRODUCTION

6. MARKETING OR SALES

7. INFORMATION SYSTEMS

8. HUMAN RESOURCES

9. OTHER, please specify: 
3. What is the level of your position? (circle number)
1. EXECUTIVE
2. MANAGER
3. SUPERVISOR
4. PROFESSIONAL
5. TECHNICAL
6. CLERICAL OR SECRETARIAL
7. OTHER, please specify:

4. What is your age? YEARS

5. What is your gender? (circle number)
1. FEMALE
2. MALE

6. Which is the highest level of education that you have completed? (Circle the last category that applies)

1. SOME HIGH SCHOOL

2. COMPLETED HIGH SCHOOL

3. SOME COLLEGE OR UNIVERSITY COURSES

4. COLLEGE DIPLOMA

5. UNIVERSITY DEGREE

5. SOME GRADUATE WORK

6. A GRADUATE DEGREE

7. What is your primary educational background? (circle number)
1. ARTS
2. MATH/SCIENCE
3. SOCIAL SCIENCE
4. BUSINESS
5. ENGINEERING
6. LAW
7. COMPUTER SCIENCE
8. OTHER, please specify:

Thank you very much for your assistance! 
Appendix 4: Link Between Theoretical Model and Interview Questions

Theoretical Model Variable

Related Management

Related Computer Support

Interview Question

Personnel Question

Organizational Structure:

$\begin{array}{ll}\text { structure } & 1,2,4,5,6,27 \\ \text { reporting } & 3 \\ \text { rank of IS executive } & 3\end{array}$

Management Attitude /

Practices

policies and planning 28

reactive/proactive 19

service orientation 25

hiring practices 7

success measurement 20,24

direction 26

competence

communication 29

10

$\begin{array}{ll}29 & 12\end{array}$

Computer Support Personnel

personality type

8

experience / training /

8

$2,3,4$

education

opinion of end users

view of role

11

turnover

11

advancement

11

morale

11

2

stress

11

job satisfaction / motivation commitment

communication

29

$3,4,9$

$3,4,8$

5

8,5

5

1

7

6

12 


\begin{tabular}{|c|c|c|}
\hline Theoretical Model Variable & $\frac{\text { Related Management }}{\text { Interview Question }}$ & $\begin{array}{l}\text { Related Compute } \\
\text { Personnel Questi }\end{array}$ \\
\hline \multicolumn{3}{|l|}{ End User Experience/Needs } \\
\hline computer skill level & 14 & end user survey \\
\hline type of support required & 16 & \\
\hline reason for requiring support & 16 & \\
\hline training & 17,18 & 11 \\
\hline peer support & 15 & end user survey \\
\hline communication & 29 & 12 \\
\hline \multicolumn{3}{|l|}{ Resources } \\
\hline time & 21 & 1 \\
\hline money & 21 & 1 \\
\hline personnel & 21 & 1 \\
\hline equipment / products & 21 & 1 \\
\hline training / development & 12,21 & 1 \\
\hline
\end{tabular}




\section{Appendix 5: Letter to Prospective Participants}

Dear [Recipient]:

I am a graduate student with the School of Business at Carleton University. I am presently working on my thesis to fulfill the requirements for a Master's of Management Studies degree.

My thesis examines the effectiveness of the Computer Support function within organizations. Professor Deborah Compeau with the School of Business is also conducting a long-term, in-depth study on the Computer Support function. There has been little research published examining how organizations can provide effective computer support to their employees and how the support function impacts the overall organization. Our goal is to gain a better perspective of the Computer Support function and make recommendations on how to improve its effectiveness within organizations.

We are looking for organizations to participate in this study. The study will consist of interviews with three managers and four computer support personnel as well as a mail survey of end users. This will be completed within fifteen organizations. The resulting data will be examined for trends to explore the relationships between the organizational structure, management attitudes/practices, computer support personnel, end user experience/needs, resources, and the effectiveness of the computer support function. The names of participating organizations will remain anonymous but will be medium-to-large companies who support business systems (i.e. financial, word processing, etc.).

A report of the study results will be sent to you upon completion and will include a comparison of the results of your organization's part in the study to the overall results.

Please contact me if you are interested in participating in this study. I will call you shortly in case you have any questions. I look forward to the opportunity to speaking with you in the near future.

Sincerely,

Marlene Elliott 


\section{Appendix 6: Instrument Evaluation Details}

\section{SERVQUAL Instrument}

The SERVQUAL instrument as per Pitt et al. (1995) was used as a measure of service quality. A single question pertaining to the computer support function's overall quality is also used. SERVQUAL can be calculated using the Perceptions Only model or using the Gap model (perceptions - expectations).

The SERVQUAL Perceptions only dimensions were calculated from the survey using:

$$
\begin{aligned}
& \text { tangibles }=p 1+p 6+p 12+p 18 \\
& \text { reliability }=p 2+p 8+p 15+p 17+p 21 \\
& \text { responsiveness }=p 3+p 10+p 16+p 19 \\
& \text { assurance }=p 4+p 9+p 14+p 23 \\
& \text { empathy }=p 5+p 7+p 11+p 13+p 20
\end{aligned}
$$

The SERVQUAL Gap dimensions were calculated from the survey using:

$$
\begin{aligned}
& \text { tangibles }=(e 1-p 1)+(e 6-p 6)+(e 12-p 12)+(e 18-p 18) \\
& \text { reliability }=(e 2-p 2)+(e 8-p 8)+(e 15-p 15)+(e 17-p 17)+(e 21-p 21) \\
& \text { responsiveness }=(e 3-p 3)+(e 10-p 10)+(e 16-p 16)+(e 19-p 19) \\
& \text { assurance }=(e 4-p 4)+(e 9-p 9)+(e 14-p 14)+(e 23-p 23) \\
& \text { empathy }=(e 5-p 5)+(e 7-p 7)+(e 11-p 11)+(e 13-p 13)+(e 20-p 20)
\end{aligned}
$$


There are some survey questions that may be questionable according to notes written on the surveys or just the appropriateness of the question:

- p6 - visually appealing physical facilities

- p12 - appearance of the physical facilities of these IS units are in keeping with the kind of services provided

- p18 - employees well dressed and neat in appearance

The reliability, validity, and generalizability of the SERVQUAL instrument was examined.

$\underline{\text { Reliability }}$

The reliability of each of SERVQUAL's dimensions was examined for the Perceptions Only, Gap, and Expectations instruments. Cronbach's alpha was used to determine the reliabilities. Analysis was done to validate that dropping an item from the scale would produce a more reliable instrument. No large discrepancies were found. Minor differences are noted. Please refer to Table 68 for the results. 


\begin{tabular}{|c|c|c|c|c|c|c|c|}
\hline & & \multirow{2}{*}{\multicolumn{4}{|c|}{ Current Study }} & \multirow{3}{*}{\multicolumn{2}{|c|}{$\begin{array}{l}\text { Past Study } \\
\text { SERVQUAL Gap } \\
\text { for Financial } \\
\text { Institution }^{65} \\
\end{array}$}} \\
\hline & & & & & & & \\
\hline & & \multicolumn{2}{|c|}{$\begin{array}{c}\text { SERVQUAL } \\
\text { Perceptions Only }\end{array}$} & \multicolumn{2}{|c|}{$\begin{array}{c}\text { SERVQUAL } \\
\text { Gap }\end{array}$} & & \\
\hline Dimension & $\begin{array}{l}\text { \# of } \\
\text { items }\end{array}$ & $\begin{array}{l}\text { Sample } \\
\text { Size } \\
\end{array}$ & $\begin{array}{l}\text { Reliability } \\
\text { Coefficients }\end{array}$ & $\begin{array}{l}\text { Sample } \\
\text { Size } \\
\end{array}$ & $\begin{array}{l}\text { Reliability } \\
\text { Coefficients }\end{array}$ & $\begin{array}{l}\text { Sample } \\
\text { Size } \\
\end{array}$ & $\begin{array}{l}\text { Reliability } \\
\text { Coefficients }\end{array}$ \\
\hline Tangibles & 4 & 253 & $0.74^{66}$ & 251 & $0.67^{67}$ & 237 & 0.62 \\
\hline Reliability & 5 & 267 & 0.92 & 263 & 0.92 & 237 & 0.87 \\
\hline $\begin{array}{l}\text { Responsivene } \\
\text { ss }\end{array}$ & 4 & 268 & 0.90 & 261 & 0.87 & 237 & 0.66 \\
\hline Assurance & 4 & 263 & 0.89 & 260 & 0.88 & 237 & 0.79 \\
\hline Empathy & 5 & 265 & $0.89^{68}$ & 262 & 0.87 & 237 & 0.75 \\
\hline Overall & 5 & 243 & $0.90^{69}$ & 234 & $0.92^{70}$ & & \\
\hline
\end{tabular}

Table 68: SERVQUAL Instrument Reliability

${ }^{65}$ Source: Pitt et al. 1995

${ }^{66} 0.76$ if drop question 1

${ }^{67} 0.69$ if drop question 1

${ }^{68} 0.90$ if drop question 11

${ }^{69} 0.96$ if drop tangibles

${ }^{70} 0.95$ if drop tangibles 


\begin{tabular}{|l|l|l|l|}
\cline { 3 - 4 } \multicolumn{2}{c|}{} & \multicolumn{2}{c|}{$\begin{array}{c}\text { SERVQUAL } \\
\text { Expectations Only }\end{array}$} \\
\hline Dimension & $\begin{array}{l}\text { \# of } \\
\text { items }\end{array}$ & Sample Size & $\begin{array}{l}\text { Reliability } \\
\text { Coefficients }\end{array}$ \\
\hline Tangibles & 4 & 265 & 0.41 \\
\hline Reliability & 5 & 266 & 0.93 \\
\hline Responsiveness & 4 & 263 & 0.84 \\
\hline Assurance & 4 & 264 & 0.88 \\
\hline Empathy & 5 & 268 & 0.86 \\
\hline
\end{tabular}

Table 69: SERVQUAL Expectations Instrument Reliability

\section{Computation Notes:}

Reliability calculated by each dimension using:

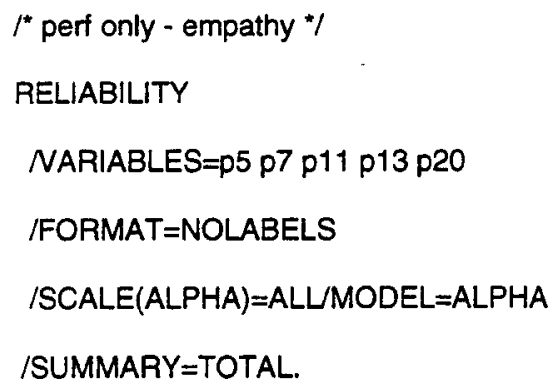

Reliability of the linear combination calculated using:

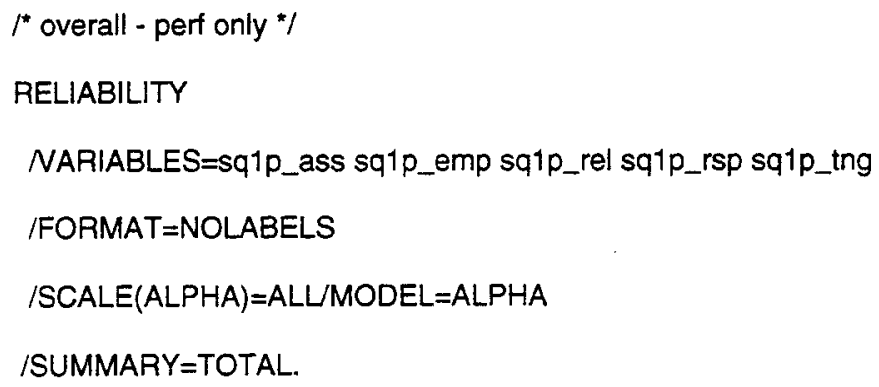


Validity

The overall service quality rating, computed from the five dimensions for both the perceptions only and gap model, was compared to the single response on the IS department's overall quality. The high correlation between the two measures indicates convergent validity.

\begin{tabular}{|c|c|c|}
\hline & $\begin{array}{l}\text { Perceptions } \\
\text { Only }\end{array}$ & Gap \\
\hline $\begin{array}{l}\text { Correlation } \\
\text { coefficient }\end{array}$ & 0.90 & 0.76 \\
\hline $\mathrm{p}$ value & $<0.01$ & $<0.01$ \\
\hline
\end{tabular}

Table 70: Convergent Validity

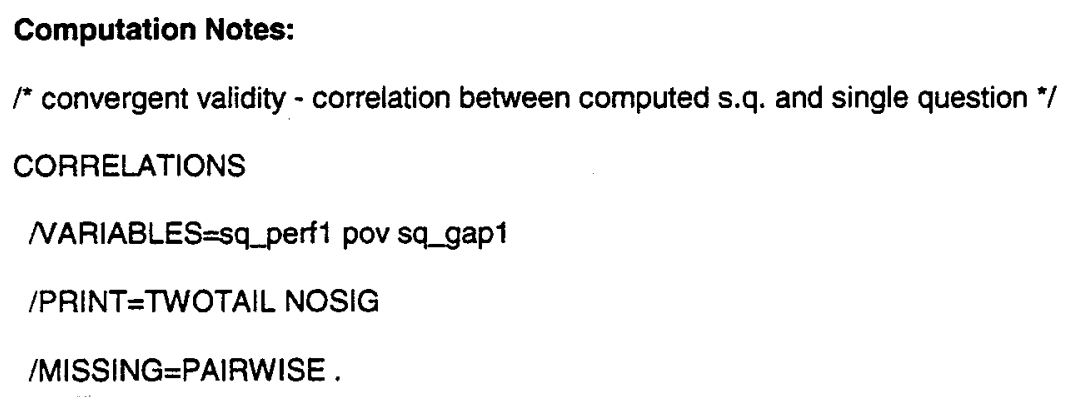

Principal components factor analysis with a varimax rotation was done for the perceptions only items as well as for the gap items. All factors with eigenvalues greater than one were selected. The sample size was 273 . The critical value for a correlation coefficient at $\alpha=0.01$ for a 2 -tailed significance test is 0.163 . The critical value for a significant loading is $2 * 0.163=0.326$. (Stevens, 1992, p. 383). Only significant loadings will be displayed in the below analysis. 
The results for the perceptions only model factor analysis are as follows:

\begin{tabular}{|c|c|c|c|}
\hline & \multicolumn{2}{|c|}{$\begin{array}{c}\text { Rotated } \\
\text { Component } \\
\text { Matrix }_{\mathbf{a}}\end{array}$} & \multirow[b]{3}{*}{$\begin{array}{c}\text { SERVQUAI } \\
\text { Dimension }\end{array}$} \\
\hline & \multicolumn{2}{|c|}{ Component } & \\
\hline & 1 & 2 & \\
\hline P15 & .859 & & reliability \\
\hline $\mathrm{P} 23$ & .832 & & assurance \\
\hline P17 & .827 & & reliability \\
\hline P13 & .820 & & empathy \\
\hline$\overline{\mathrm{P} 3}$ & .814 & & responsiveness \\
\hline $\mathrm{P9}$ & .812 & .381 & assurance \\
\hline $\mathrm{P} 8$ & .807 & & reliability \\
\hline P19 & .806 & & responsiveness \\
\hline P16 & .769 & & responsiveness \\
\hline $\mathrm{P} 2$ & .753 & .326 & reliability \\
\hline P10 & .738 & & responsiveness \\
\hline P5 & .738 & & empathy \\
\hline $\mathrm{P} 20$ & .729 & .405 & empathy \\
\hline $\mathrm{P} 4$ & .693 & .411 & assurance \\
\hline
\end{tabular}




\begin{tabular}{|l|l|l|l|}
\hline P7 & .691 & .459 & empathy \\
\hline P14 & .679 & & assurance \\
\hline P11 & .431 & .419 & empathy \\
\hline P12 & & .778 & tangibles \\
\hline P6 & & .758 & tangibles \\
\hline P18 & & .679 & tangibles \\
\hline P1 & & .590 & tangibles \\
\hline P21 & .509 & .577 & reliability \\
\hline
\end{tabular}

\section{Table 71: SERVQUAL Dimensions}

Extraction Method: Principal Component Analysis.

Rotation Method: Varimax with Kaiser Normalization.

a: Rotation converged in 3 iterations.

A two factor model is found. The reliability items with the exception of P21 load together on the first factor. P21 is split pretty evenly between the two factors. The empathy, responsiveness, and assurance items all load together on the first factor. The tangibles items all load together on the second factor. Items expected to load together do (with the exception of P21).

Since the reliability, assurance, empathy, and responsiveness items seem to load together in one factor and not separate factors, there is a problem with the discriminant validity. The tangibles items load close to expectations on their own factor. 


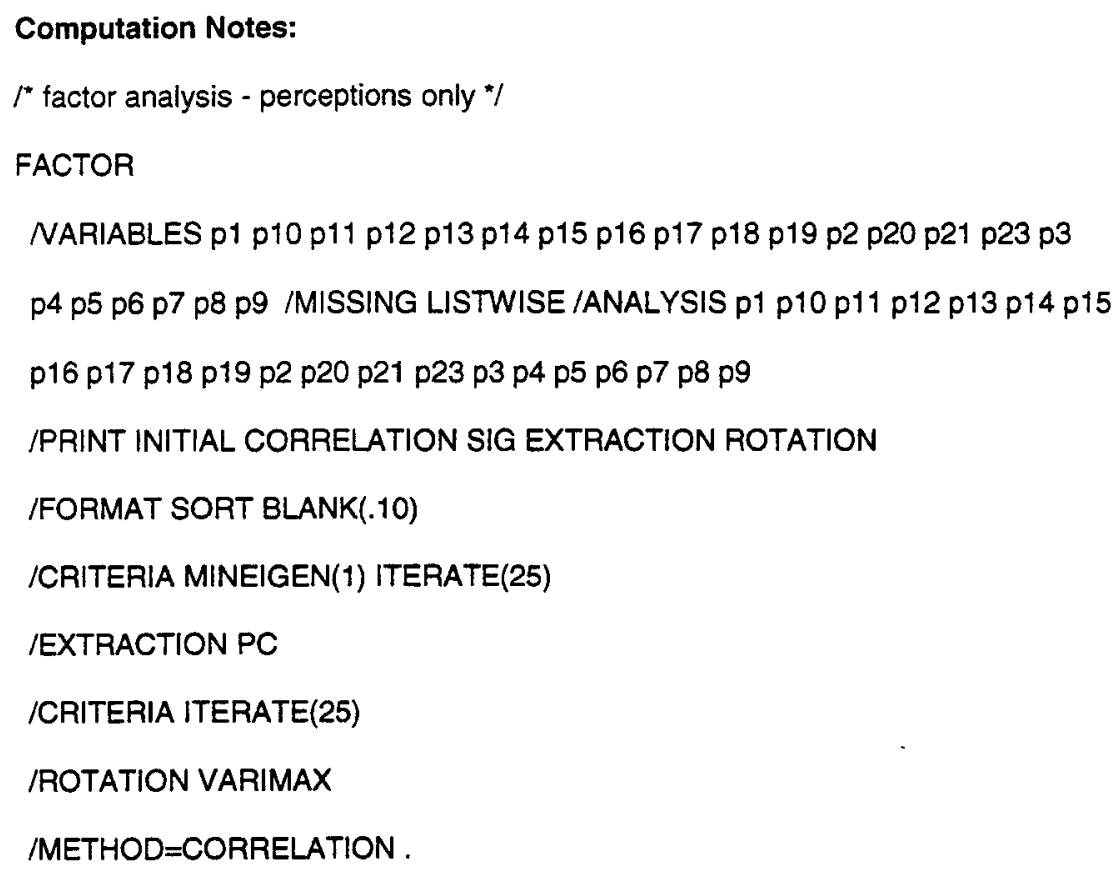

\section{$\underline{\text { Reliability of User Information Satisfaction Instrument }}$}

Galletta and Lederer's (1989) four summary USISF items were administered to the end-users to obtain a measurement of user satisfaction with the information services function.

S1: Satisfaction with Involvement and Participation

S2: Satisfaction with Support and Services

S3: Satisfaction with Product

S4: Overall Satisfaction with IS Environment

The reliability was 0.89 as shown in Table 72 . 


\begin{tabular}{|l|l|l|l|}
\hline & \# of Items & Sample Size & Reliability Coefficient \\
\hline S1, S2, S3, S4 & 4 & 266 & $0.89^{71}$ \\
\hline
\end{tabular}

Table 72: USISF Reliability

\section{Reliability of End User Sophistication Instrument}

Munro et al.'s (1995) end user sophistication items were administered in the survey. The breadth, depth, and finesse values are examined. Their reliabilities were all above 0.90 as shown in Table 73. Analysis determined that no items should be dropped in any of the scales.

\begin{tabular}{|l|l|l|l|}
\hline & $\begin{array}{l}\text { \# of } \\
\text { Items }\end{array}$ & Sample Size & $\begin{array}{l}\text { Reliability } \\
\text { Coefficient }\end{array}$ \\
\hline Breadth & 31 & 240 & 0.92 \\
\hline Depth & 31 & 263 & 0.94 \\
\hline Finesse & 5 & 262 & 0.96 \\
\hline
\end{tabular}

Table 73: End User Sophistication Reliabilities

${ }^{71} 0.90$ if $\mathrm{S} 1$ is dropped 